U. S. DEPARTMENT OF COMMERCE NATIONAL BUREAU OF STANDARDS

\title{
REPORT OF THE
}

THIRTY-FIFTH NATIONAL CONFERENCE ON WEIGHTS AND MEASURES

ATTENDED BY REPRESENTATIVES FROM VARIOUS STATES

SPONSORED BY THE NATIONAL BUREAU OF STANDARDS WASHINGTON, D. C., MAY 23, 24, 25, and 26, 1950

MISCELLANEOUS PUBLICATION 199 




\title{
U. S. DEPARTMENT OF COMMERCE \\ CHARLES SAWYER, Secretary \\ NATIONAL BUREAU OF STANDARDS \\ E. U. CONDON, Director
}

\section{MISCELLANEOUS PUBLICATION 199}

\section{REPORT OF THE}

\section{THIRTY-FIFTH NATIONAL CONFERENCE}

\author{
ON
}

\section{WEIGHTS AND MEASURES}

\section{ATTENDED BY REPRESENTATIVES \\ FROM VARIOUS STATES}

\section{SPONSORED BY THE NATIONAL BUREAU OF STANDARDS}

WASHINGTON, D. C., MAY 23, 24, 25, and 26, 1950

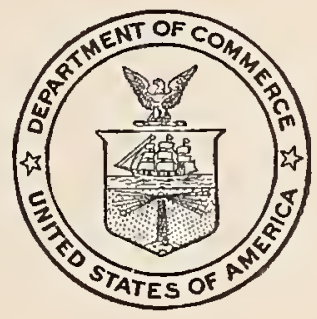

UNITED STATES

GOVERNMENT PRINTING OFFICE

WASHINGTON : 1950 


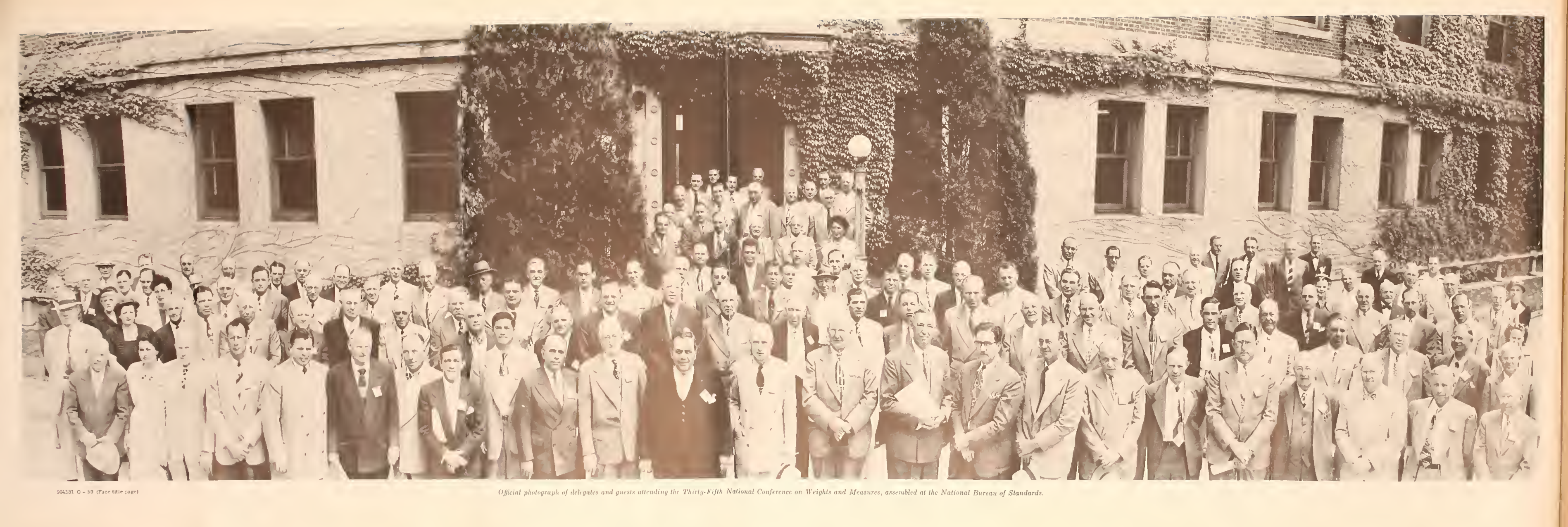






\section{OFFICERS AND COMMITTEES}

\section{OFFICERS}

(Present and serving during the Thirty-fifth National Conference)

Presideut: E. U. Condon, Director, National Bureau of Staudards, Washingtou, D. C.

Vice Presidents :

C. A. BAKER, Director, State Bureau of Weights and Measures, Department of Agriculture and Markets, Albany, N. X.

J. E. Brenton, Chief, State Bureau of Weiglits and Measures, Department of Agriculture, Sacramento, Calif.

A. J. Jensen, Chief State Inspector of Treights and Measures, Public SerYice Commission, Jamestown, N. Dak.

J. T. KEnnedy, Director, Department of iveights, Measures, and Iarkets, District of Columbia, Washington, D. C.

J. P. Leonard, City Superintendent of Weights and Measures, Paterson, N. J.

C. C. Mundy, Chief, City Bureau of Weights and Measures, Richmond, Va. Secretary : R. W. Survi, Chief, Office of Weights and Measures, National Bureau of Standards, Washington, D. C.

Treasurer: G. F. Austin, Jr., Deputy Sealer of Weights and Measures, Detroit, Mich.

(As elected by the Thirty-fifth National Conference for the ensuing year)

President : E. U. Condon, Director, National Bureau of Standards, Washington, D. C.

Vice Presidents :

C. A. BAKEr, Director, State Bureau of Weights and Mesaures, Department of Agriculture and Markets, Albany, N. Y.

J. E. Brenton, Chief, State Bureau of Weights and Mesaures, Department of Agriculture, Sacramento, Calif.

V. D. Camplecl, Deputy State Sealer, Department of Agriculture, Columbus, Ohio.

J. T. Kennedy, Director, Department of Weights, Measures, and Markets, District of Columbia, Washington, D. C.

H. E. How ARD, City Supervisor of Weights and Measures, Miami, Fla.

F. C. Yarbiough, City Inspector of Weights and Measures, Charlotte. N. C. Secretary : R. IV. Smith, Chief, Office of Wéghts and Measures, National Bureau of Standards, Waslington, D. C.

Treasurer: G. F. Austin, Jn., Deputy Sealer of IVeights and Measures, Detroit, Mich.

\section{EXECUTIVE COMMITTEE}

(As elected by the "Thirty-fifth National Conference)
E. U. CONDON
C. A. BAKER
J. E. BRentoN
V. D. CAMPBElL
J. T. KEN NEUY
H. E. HoWARD
F. C. Yarbrottgh
R. W. SMITH
G. F. Austin, JR.

J. F. Blickley, Director, State Bureau of Standard Weights and Measures, Harrisburg, Pa.

G. E. Carpexter, Supervisor, State Division of Weights and Measures, Montpelier, Vt. 
F. M. Glibene, Deputy Commissioner, State Food and Drug Commission, Hartford, Comn.

Ering Hansen, Supervisor, State Department of Weights and Measures, Minneapolis, Minn.

J. A. Hrmemann, City Inspector of Weights and Measures, Fort Wayne, Ind.

II. W. Jexsen, City Sealer of Weights and Measures, Madison, Wis.

G. L. Johnson, Director, State Division of Weights and Measures, Frankfort, Ky.

J. R. Jones, Commissioner, State Department of Asticulture, Columbia, S. C.

O. A. IIRKLand, Inspectol, State Division of Weights and Measures, Austin, Tex.

J. J. LEvitT, State Smperintendent of Standards, Springfield, Ill.

J. P. McBride, State Director of Standards and Necessaries of Life, Boston. Mass.

M. A. Nerson, Chief, State Bureau of Marketing and Enforcement, Lansing, Mich.

J. G. Rogers, Deputy Superintendent, State Division of Weights and Measures, Trenton, N. J.

J. F. True, Sealer, State Weights and Measures Division, Topeka, Kan.

C. J. Wills, Jr., City Sealer of Weights and Measures, Iortland, Maine.

\section{STANDING COMMITTEES}

(As constituted at the conclusion of the 35th National Conference, the personnel and organization of each of the standing committees of the Conference are as reported below. As reported, the membership of eacli conmittee reflects the appointments made by the President of the Conference, changes which have occurred from expiration of term or other cause, and the elections by the several committees of chairmen, and in some cases secretaries, for the ensuing year. The term of office for each committee member, in years, is shown by the figure in parenthesis following eacll entry.)

\section{COMMITTEE ON SPECIFICATIONS AND TOLERANCES}

J. P. McBride, State Director of Standards and Necessaries of Life, Boston, Mass., Chailman. (3)

W. S. Busser, Assistant Chief, Office of Weights and Measures, National Bureau of Standards, Washington, D. C., Secretary. (5)

G. F. Austrn, Jr., Deputy City Sealer of Weights and Mesaures, Detroit, Mich. (1)

Nalls Berryman. Supervisor, State Dirision of Weights and Measures, Tallahassee, Fla. (2)

L. E. WirT, City Sealer of Weights and Measures, Milwaukee, Wis.

\section{COMMITTEE ON METHODS OF SALE OF COMMODITIES}

J. G. Rogers, Deputy State Superintendent of Weights and Measures, Trenton, N. J., Chairman. (5)

R. S. AcKerman, Superintendent, City Department of Licenses, IVeights and Measures, Minneapolis, Minn. (2).

C. D. Baucom, State Superintendent, Weights and Measures Division, Raleigh, N. C. (4)

J. F. Blrchler, Director, State Bureau of Standard Weights and Measures, Harrisburg, Pa. (1)

L. R. Roper, City Supelvisor of Licenses and Standards, Seattle, IVash.

\section{COMMITTEE ON LEGISLATION}

R. E. MEer, Dilector, State Division of Weights and Measures, Indianapolis, Ind., Chairman. (5)

C. A. BAKEr, Director, State Bureau of Weights and Measures, Albany, N. Y.

J. A. Bernard, City Commissioner of Weights and Measures, St. Louis, Mo.

J. R. Bootm, City Sealer of WVeights and Measules, Haverhill, Mass. (4)

C. H. OAKLEY, State Inspector of Weights and Measures, Cheyenne, Wyo.

\section{COMMITTEE ON WEIGHTS AND MEASURES EDUCATION}

C. M. Fulcer, County Sealer of Weights and Measures, Los Angeles, Calif., Chairman. (5)

J. T. KenNeDr, Director, Department of Weights, Measures, and Markets, District of Columbia, Washington, D. C., Secretary. 
G. E. Carpenter, State Supervisor of Weights and Measures, Montpelier, vt.

IR. K. Slough, City Sealer of Weights and Measures, Akron, Ohio, (2)

Robert Wrutuas, County Sealer of Weights and Measures, Mineola, N. X.

\section{COMMITTEE ON TRADING BY WEIGHT}

J. F. True, State Sealer, Weights and Measures Division, Topeka, Kan., Chairman. (4)

F. G. Cesar, Director, State Marketing Division, Oklahoma City, Okla. (1)

ErLivg Hansen, Supervisor, State Department of Weights and Measures, Minneapolis, Minn. (2)

J. J. LevitT, State Superintendent of Standards, Springfield, Ill. (5)

J. H. MEeK, Director. State Division of Markets, Richmond, Va. (3)

\section{SPECIAL COMMITTEE ON UNIFORM REGULATIONS}

R. D. Thompson, Supervisor, State Weights and Measures Section, Richmond, Va., Chairman.

D. A. Fraser, County Sealer of Weights and Measures, Salem, Conn.

C. I. Hoen, Assistant Supervisor, State Department of Weights and Measures, Minneapolis, Minn.

J. W. ReEse, Superintendent, State Weights and Measures Division, Des Moines, Iowa.

E. C. Westwood, City Sealer of Weights and Measures, Salt Lake City, Utah.

\section{SPECIAL COMMITTEE ON THE TESTING OF RAILWAY TRACK SCALES ${ }^{3}$}

J. P. McBride, State Director of Standards and Necessaries of Life, Boston, Mass., Chairman.

J. E. Brenton, Chief, State Bureau of Weights and Measures, Sacramento, Calif. ERLing Hansen, Supervisor, State Department of Weights and Measures, Minneapolis, Minn.

\section{COMMITTEES ACTING ONLY DURING THE THIRTY-FIFTH NATIONAL CONFERENCE}

Committce on Nominations: R. E. MeEk of Indiana, Clatirman: J. A. Bervard of St. Louis, Mo, Nalls Berryman of Florida, J. A. Boyle of Maine, Alfred Lirro of Cumberland County, N. J., W. F. MAsinda of Tolland County, Coun., G. W. WARNER of Wisconsin.

Committce on Resolutions: J. J. LevitT of Illinois, Chairman; F. M. Greene of Connecticut, G. L. JoHrson of Kentucky, W. A. KerLIN of Alameda County, Calif., Wriliam Kirk, Jr., of Nassau County, N. Y., R. WV. Searles of Medina County, Ohio, S. H. Selghara of Pennsylvania.

Ladies' Committee: Mrs. R. E. MeEk, Chairman; Mrs. W. S. Bussex; Mrs. J. M. DiETz.

In charge of Registrations: Mrs. R. E. TAYLoR.

1 This Committee was appointed by the Conference President following the adjournment of the 35 th National Conference, pursuant to the resolution of the Conference reported on page 166 . 


\section{PERSONS ATTENDING THE CONFERENCE}

\section{DELEGATES-STATE, CITY, AND COUNTY OFFICIALS}

\section{CALIFORNIA}

State.

County:

Alameda

Los Angeles

\section{Measures, 333 Fifth Street, Oakland 7.}

Charles Morris Fulier, Sealer of Weights and Measures, 3200 North Main Street, Los Angeles 31.

\section{COLORADO}

State

Oscar Herigstad, Markets Inspector, 20 State Museum Building, Denver.

\section{CONNECTICUT}

State

Franje M. Greene, Deputy Commissioner, Food and Drug Commission, State Capitol Building, Hartford.

City:

Bridgeport

Ilartford County:

Fairfield

IIartford

Tolland

Lours Snow, Sealer of Weights and Measures, 925 Main Street.

Nathan Kalechman, Sealer of Weights and Measures, Municipal Building.

William E. Sheeny, Sealer of Weights and Measures, County Court House, Bridgeport.

Fred E. McKinney, County Sealer of Weights Measures, 95 Washington Street, Hartford.

William F. Masinda, Sealer of Weights and

Measures, West Willington.

\section{DISTRICT OF COLUMBIA}

District

J. Thomas Kennedy, Director, Department of Weights, Measures, and Markets, 300 Indiana Avenue NW., Washington.

James G. Dance, Deputy Direetor, Department of Weights, Measures, and Markets, 300 Indiana Avenue NW., Washington.

JoHN M. Boucher, Supervisor, Department of Weights, Measures, and Markets, 300 Indiana Avenue NW., Washington.

Georce Stuart Rement, Senior Inspector and Investigator, Department of Weights, Measures, and Markets, 300 Indiana Avenue NW., Washington.

LEO F. BRoOrs, Inspector and Investigator, Department of Weights, Measures, and Markets, 300 Indiana Avenue NW., Washington. 
District-Continued

Fenton C. Harbour, Inspeetor and Investigator, Department of Weights, Measures, and Markets, 300 Indiana Avenue NW., Washington.

William H. Jennincis, Inspeetor and Investigator, Department of Weights, Measures, and IIarkets, 300 Indiana Avenue NW., Washington.

HERBERT R. STronc, Inspeetor and Investigator, Department of Weights, Measures, and Markets, 300 Indiana Avenue NW., Washington.

Francis M. WARNER, Inspeetor and Investigator, Department of Weights, Measures, and Markets, 300 Indiana Avenue NW., Washington.

Walter W. Brandt, Inspector, Department of Weights, Measures, and Markets, 300 Indiana Avenue NW., Washington.

Walter R. Cornelius, Inspector, Department of Weights, Measures, and Markets, 300 Indiana Avenue NW., Washington.

Theodore B. Middleton, Inspector, Department of Weights, Measures, and Markets, 300 Indiana Avenue NW., Washington.

Ralph H. Montromery, Inspeetor, Department of Weights, Measures, and Markets, 300 Indiana Avenue NW., Washington.

Bernard A. Pettit, Inspector, Department of Weights, Measures, and Markets, 300 Indiana Avenue NW., Washington.

Woodrow W. WeLls, Inspector, Department of Weights, Measures, and Markets, 300 Indiana Avenue NW., Washington.

\section{FLORIDA}

State _................. Nalls Berryman, Supervisor, Weights and Measures Division, Department of Agrieulture, Nathan Mayo Building, Tallahassee.

City:

Jacksonville

Howard E. Crawford, Inspeetor of Weights and Measures, 431 West Eighth Street.

Miami

HARVEY E. Howard, Supervisor of Weights and Measures, 321 Courthouse.

\section{ILLINOIS}

State

JoHn J. Levitt, Superintendent of Standards, Department of Agrieulture, 615 Armory Building, Springfield.

City: Chieago _........... Irvine M. Levy, Sealer of Weights and Measures, Room 608, City Hall.

Frank J. Fitrgerald, Chief Deputy Inspeetor of Weights and Measures, Room 608, City Hall.

\section{INDIANA}

State

Rollin E. MeEk, Direetor, Division of Weights and Measures, Board of Health, 1330 West Miehigan Street, Indianapolis.

City:

Fort Wayne _........... James A. Hilgemann, Inspeetor of Weights and Measures, 301 South Clinton Street.

Gary

C. C. Morgan, Sealer of Weights and Measures, City Hall.

County: Vigo

WiLliam H. RoBerts, Inspector of Weights and Measures, Room 5, Court House, Terre Haute. 
IOWA

Statc

James W. Reese, Supervisor, Division of Wcights and Measurcs, Department of Agriculture, Des Moines.

\section{KANSAS}

Statc

J. Fred True, State Sealer, Weights and Measures Division, Board of Agriculture, 915 Harrison Street, Topeka.

PaUl A. Wempe, Chairman, Weights and Measures Committee, Board of Agriculture, Seneca.

\section{KENTUCKY}

State

George L. Johnson, Dircetor, Division of Weights and Measures, Department of Agriculture, New State Capitol, Frankfort.

Joseph V. Vittitow, Ficld Agent, Department of Agriculture, 221 Saint Ann Street, Owensboro.

City: Louisville

William H. Ising, Superintendent of Weights and Measures, City Hall.

\section{LOUISIANA}

Statc

Alois J. Mayer, Director, Division of Weights and Measures, Department of Agriculture and Immigration, State Capitol Building, Baton Rouge.

\section{MAINE}

State

James A. Boyle, Deputy State Sealer, Bureau of Weights and Measures, Department of Agriculture, State House, Augusta.

City: Portland_............ Charles James Wills, Sealer of Weights and Measures, 389 Congress Street.

\section{MARYLAND}

City: Baltimore

George H. Leithauser, Senior Assistant Superintendent of Weights and Measures, 1106 Municipal Building.

Richard S. Hunter, Inspector of Weights and Measures, 1106 Municipal Building.

William I. Scheverman, Inspector of Weights and Measures, 1106 Municipal Building.

County:

Baltimore

Christian G. Link, Chief Inspector of Weights and Measures, Offutt Building, Towson 4.

George A. Klein, Inspector of Weights and Measures, Offutt Building, Towson 4.

Montgomery

A. Morton Thomas, Director, Department of Inspection and Licenses, Court House, Rockville.

\section{MASSACHUSETTS}

State

John P. McBride, Director of Standards and

City: Necessaries of Life, 194 State House, Boston.

Agawam_............. Frank Dragmettr, Sealer of Weights and Measures.

Cambridge

JosepII M. O'NeIL, Sealer of Weights and Measures, Municipal Building. 


\section{MICHIGAN}

State

Miles A. Nelson, Chief, Bureau of Marketing and Enforcement, Department of Agriculture, 725 State Office Building, Lansing 13.

City:

Dearborn

Mitcriell O. Nickon, Superintendent of Weights and Measures, 4731 Korte Street.

Detroit

Georce F. AUstin, JR., Deputy Sealer of Weights and Measures, 740 Elmwood Avenue.

William B. Heaslip, Supervising Inspector of Weights and Measures, 740 EImwood Avenue.

James H. Hitchinas, Inspector of Weights and Measures, 740 Elmwood Avenue.

Highland Park _....... JAMES F. BAFER, Sealer of Weights and Measures, 25 Gerald Avenue.

Lansing

Willard P. Barnes, Market Master and Sealer of Weights and Measures, 333 North Cedar Street.

Pontiac

WALTER A. BAERWOLF, Sealer of Weights and Measures, 8 North Perry Street.

County: Washtenaw

Georae P. Smith, Sealer of Weights and Measures, Court House, Ann Arbor.

\section{MINNESOTA}

State

Erling Hansen, Supervisor, Department of Weights and Measures, Railroad and Warehouse Conmission, 216 Corn Exchange, Minneapolis.

City: Minneapolis

Russeld S. Acrerman, Superintendent, Department of Licenses, Weights, and Measures, Room 3, City Hall.

\section{MISSOURI}

State

Rollo E. Sincleton, Director, Weights and Measures Division, Department of Agriculture, Jefferson City.

City: St. Louis

Joseph A. Bernard, Commissioner of Weights and Measures, 12 City Hall.

\section{NEBRASKA}

City

W. W. Gray, Chief Inspector of Weights and Measures, Room 100, City Hall.

\section{NEW HAMPSHIRE}

State.

Alfred H. Dittrich, Commissioner, Department of Weights and Measures, Concord.

\section{NEW JERSEY}

State

Josepi G. Rogers, Deputy Superintendent, Division of IVeights and Measures, Department of Law and Public Safety, 187 West Hanover Street, Trenton 7.

ArciIIE T. SuITIr, Assistant State Superintendent, Division of Weights and Measures, Department of Law and Public Safety, 187 West Hanover Street, Trenton 7.

Samidel H. Christie, JR., Senior Inspector, Division of Weights and Measures, Department of Law and Public Safety, 187 West Hanover Street, Trenton 7. 
City:
Englewood.

Hoboken

Paterson

Union City

\section{County:}

Bergen

Cainden

Cape May

Cumberland

Mercer

Passaic

Salem

Union
LeOnaRd DeRienzo, Superintendent of Wcights and Measures, City Hall.

Charles P. Romano, Superintendent of Weights and Measures, City Hall.

JosePH P. LEONARD, Superintendent of Weights and Measures, 115 Van Houten Street.

William J. Kehoc, Assistant Superintendent of Weights and Measures, 115 Van Houten Street.

Alfred O. Oslund, Superintendent, Department of Weights and Measures, 3715 Palisade Avenue.

Michael J. Santimauro, Superintendent of Weights and Measures, 66 Zabriskie Street, Hackensack.

Ernest E. DAwson, Assistant Superintendent of Weights and Measures, 66 Zabriskie Street, Hackensack.

Albert C. Becker, Superintendent of Weights and Measures, City Hall, Camden.

Gilbert S. Smith, Superintendent of Weights and Measures, 183 Twelfth Street, Avalon.

AlFred Lirio, Superintendent of Weights and Measures, Court House, Bridgeton.

Winfield K. Thompson, Assistant Superintendent of Weights and Measures, Court House, Bridgeton.

RALPH M. Bodenweiser, Superintendent of Weights and Measures, Court House, Trenton.

William Miller, Superintendent of Weights and Measures, Administration Building, Paterson.

JoHN KENNARD CRISPIN, Superintendent of Weights and Measures, 60 North Main Street, Woodstown.

James M. Dietz, Superintendent, Department of Weights and Measures, Court House, Elizabeth 4.

\section{NEW YORK}

State

Dr. ERwin V. Moore, Assistant Commissioner, Department of Agriculture and Markets, State Office Building, Albany.

Clement A. Baker, Director, Bureau of Weights and Measures, Department of Agriculture and Markets, State Office Building, Albany.

Mattriew G. Rice, Inspector, Bureau of Weights and Measures, Department of Agriculture and Markets, 8 Marlette Place, White Plains.

City:

Binghamton ............

Harry A. Lason, Sealer of Weights and Measures, 201 Eldridge Street.

New York.................... Fed J. Loughran, Director, Bureau of Weights and Measures, 137 Centre Street.

MatThew A. DonohUE, Inspector of Weights and Measures, 137 Centre Street.

Rochester ............. Anthony C. SAmenfink, Sealer of Weights and Measures, Public Market.

County:

Delaware.

Guy T. Parsons, Sealer of Weights and Measures, 8 Woolerton Street, Delhi.

Monroe.
EarL D. Hubble, Sealer of Weights and Measures, 1400 South Avenue, Rochester. 


\section{County-Continued}

Nassalı

Rockland

State

City: Charlotte

State

City: Akron

County:

Medina

Summit

Wood
Robert Williams, Sealer of Weights and Measures, Old County Court House Annex, Mineola.

Wrlliam Kirk, Jr., Assistant Sealer of Weights and Measures, Old County Court House Annex, Mineola.

Thomas A. Shankey, Sealer of Weights and Measures, 2 Main Street, Haverstraw.

\section{NORTH CAROLINA}

C. D. BaUCOM, Superintendent, Weights and Measures Division, Department of Agriculture, 415 Agriculture Building, Raleigh.

JoHn I. Moore, Supervising Inspector, Weights and Measures Division, Department of Agriculture, 415 Agriculture Building, Raleigh.

E. W. Hessee, Senior Chemist, Weights and Measures Division, Department of Agriculture, Raleigh.

Roy P. WoOdall, Inspector, Weights and Measures Division, Department of Agriculture, Raleigh.

Fred C. Yarbrough, Inspector of Weights and Measures, 2100 Brandon Circle.

\section{NORTH DAKOTA}

A. J. Jensen, Chief Inspector of Weights and Measures, Public Service Commission, Jamestown.

\section{OHIO}

C. W. Van Schoik, Chief, Division of Food and Dairies, Department of Agriculture, Columbus 15 .

V. D. Camprell, Deputy State Sealer, Department of Agriculture, 710 State Office Building, Columbus.

ROBERT K. Slotgh, Sealer of Weights and Measures, 102 Municipal Building.

Robert W. Searles, Deputy Sealer of Weights and Measures, Court House, Medina.

LE RoY Wolford, Deputy Sealer of Weights and Measures, Court House, Akron.

LEON E. BATES, Deputy Sealer of Weights and Measures, Rising Sun.

\section{OKLAHOMA}

T. C. BECK, Assistant Director, Marketing Division, Board of Agriculture, 122 State Capitol Building, Oklahoma City.

R. L. Flanagan, Supervisor of Weights and Measures, Division of Markets, Board of Agriculture, 122 Capitol Building, Oklahoma City.

\section{PENNSYLVANIA}

Joseph F. Burckley, Director, Bureau of Standard Weights and Measures, Department of Internal Affairs, Capitol Building, Harrisburg.

Spencer H. Serghman, Assistant Director, Bureau of Standard Weights and Measures, Department of Internal Affairs, Capitol Building, Harrisburg.

Harry E. Shomper, Senior Inspector, Bureau of Standard Weights and Measures, Department of Internal Affairs, Capitol Building, Harrisburg. 


\section{PUERTO RICO}

Insular................... José R. Rivera, Chief Engineer, Public Service Commission, San Jual.

\section{RHODE ISLAND}

State _................ Edward R. Fisher, State Sealer of Weights and Measures, Department of Labor, State House, Providence.

James F. Corrigan, Deputy State Sealer of Weights and Measures, Department of Labor, State House, Providence.

City: Cranston ............ Armand E. Renzi, Sealer of Weights and Measures, 70 Harris Avenue.

\section{SOUTH CAROLINA}

State .................... Joy Jones, Commissioner, Department of Agriculture, P. O. Box 1080, Columbia.

Chovine R. Sprott, Deputy Commissioner, Department of Agriculture, Columbia.

\section{TEXAS}

State_................. Oran A. Kirkland, Inspector, Division of Weights and Measures, Department of Agriculture, Austin.

\section{UTAH}

City: Salt Lake City

E. C. Westwood, Sealer of Weights and Measures, 118 East First South.

\section{VERMONT}

State

George E. Carpenter, Supervisor, Division of Weights and Measures, Department of Agriculture, Montpelier.

\section{VIRGINIA}

State_........... R. Thompsov, Supervisor, Weights and Measures Section, Division of Markets, Department of Agriculture and Immigration, 1200 East Main Street, Richmond 19.

Walter L. Grax, Inspector, Weights and Measures Section, Division of Markets, Department of Agriculture and Immigration, Box 422, Bristol.

J. Alvin Rosen, Inspector, Weights and Measures Section, Division of Markets, Department of Agriculture and Immigration, Staunton.

City:

Norfolk

Webster K. Tripple, Chief, Bureau of Weights and Measures, City Market Building.

Portsmouth

Robert G. Esleeck, Assistant Sealer of Weights and Measures, Market Building.

Richmond ........... ConwAY C. Mundx, Chief, Bureau of Weights and Measures, Room 121, Mosque Building, Laurel and Main Streets.

Marion L. Rice, Chief Deputy Inspector, Bureau of Weights \& Measures, Laurel \& Main Sts.

A. I. BrockwelL, Inspector, Bureau of Weights and Measures, Room 121, Mosque Building, Laurel and Main Streets.

Roanoke............. John W. Orenchain, Sealer of Weights and Measures, City Market.

\section{WASHINGTON}

City: Seattle_.

Donald M. Turnbull, Supervisor, Division of Licenses and Standards, Office of the Comptroller, 100 County-City Building. 


\section{WISCONSIN}

State

George IV. Warner, Supervisol, Weights and Measures Inspection, Department of Agriculture, Capitol Building, Madison.

City:

Madison

Malcom IV. Jensen, Sealer of Weights and Measures, 101 North Blount Street.

Nilwaukee

Louis E. WI'T, Sealer of Weights and Neasures, 1331 North Fifth Street.

Racine

Robert Zierten, Sealer of Weights and Measures, City Hall.

Sheboygan _._._. Joseph A. Peikert, Sealer of Weights and Neasures, City Hall.

Superior

Oscar E. Roeseler, Sealer of Weights and Measures, City Hall.

West Allis

Arthur E. La Boda, Sealer of Weights and Measures, 7525 West Greenfield Avenue.

\section{WYOMING}

State

Charles H. OAkLeY, Inspector of Weights and Measures, Department of Agriculture, 310 Capitol Building, Cheyenne.

\section{DELEGATES-NATIONAL BUREAU OF STANDARDS}

Director's Office :

E. U. Condon, Director.

Lyman J. Briggs, Director Emeritus.

RALPH W. SMITH, Chief, Office of Weights and Measures.

William S. Bussey, Assistant Chief, Office of Weights and Measures.

Mrs. K. M. ScHWarz, Attorney-Editor, Office of Weights and Measures.

Mrs. R. E. TAYLOR, Office of Weights and Measures.

Zachanx Fontunato, Office of Weights and Measures.

Metrology Division:

Wilmer Souder, Chief.

Peter Hidnert, Chief, Thermal Expansion Section.

Lewis V. Judson, Chief, Length Section.

Francis C. Morer, Capacity, Density, and Fluid Meters Section.

H. Haig Russell, Chief, Scale Section.

Chemistry Division:

Elmer R. Weaver, Chief, Gas Chemistry Section.

J. H. Erseman, Gas Chemistry Section.

Mechanics Division:

D. R. TAte, Engineering Mechanies Section.

Organic and Fibrous Matelials Division:

R. S. Cleveland, Testing and Specifications Section.

\section{GUESTS REPRESENTING UNITED STATES GOVERNMENT}

U. S. Department of Agriculture:

Charles L. Richard, Supervisor of Scales and Weighing, Packers and Stockyards Division, Room 3530 South Building, Washington 25, D. C.

Robert J. Neale, Weights and Measures Inspector, Livestock Branch, Packers and Stockyards Division, Washington 25, D. C.

J. R. Scotr, Chief, Trade Label Section, Federal Meat Inspection Service, Room 232E, North Building, Washington 25, D. C.

U. S. Food and Drug Administration:

J. KenNETH KrRK, Assistant to. Commissioner, Washington 25, D. C.

Robert A. Osborn, Chemist, Food Division, Washington 25, D. C.

Sumner C. Rowe, Chemist, Food Division, Washington $25, \mathrm{D}$. C.

Post Office Department:

Jesse C. Miller, Commodity Specialist, Division of Equipment and Supplies, Washington 25, D. C.

Treasury Department:

FrED W. GAST, Chief, Division of Engineeling and Weighing, Burean of Customs, Washington 25, D. C. 


\section{GUESTS REPRESENTING MANUFACTURERS OF WEIGHING AND MEASURING DEVICES}

American Meter Co. : W. V. STock'on, Assistant Manager, Albany, N. Y.

American Sale Co.: W. L. Evans, Executive Vice President, 919 Baltimore Avenue, Kansas City 6, Mo.

Black \& Decker llanufacturing Co.: Eowrs E. Powell, Manager, Loadometer Department, Towson 4, Md.

Bloomer Brothers Co. : Raynor M. Holares, Research Engineer, Newark, N. Y.

bowsel, Inc. : Chemex'l P. Griffitn, Vice President, Fol't Wayne, Ind.

Brodie, Ralph N., Co., Inc. : C. J. McCarfrey, Vice President, 550 South Columbus Arenue, Mlount Vernon, N. Y.

Chatillon, John, \& Sons:

J. George Huget, Jr., Sales Representatire, 85 Cliff Street, New York, N. Y.

J. George Huget, Sr., Sales Representative, 85 Cliff Street, New York, N. Y.

E. C. Prietz, Sales Representative, 85 Cliff Street, New York, N. Y.

George C. Reiley, Vice President, Sales, 85 Cliff Street, New York, N. Y.

Detecto Scales, Inc. :

Mack Iiapp, Vice President, 540 Park Avenue, BrookIrn 5, N. Y.

Mrs. Carrie G. Woodland, Representative, Fellsmere, Fla.

Durham Scale Co.: Wibliam G. Emmons, Ellis Road, Route 4, Durham, N. C.

Exact Weiglit Scale Co.: James F. Sullyan, Chief Engineer, 944 West Fifth Avenne, Columbus, Ohio.

Ex-Cell-o Corpolation :

Eugene R. Andre, Selvice Manager, Pure-Pak Dirision, 1200 Oakman Boulevard, Detroit 32, Mich.

Geokge D. Sco't, Sales Manager, Pure-Pak Division, 1200 Oakman Boulevald, Detroit 32 , Mich.

Fairbanks, Morse \& Co.

W. N. Copeland, 1000 Vermont Areuue NW., Washington 5, D. C.

Curistian A. Hennie, Field Engineer, 2010 Loregrove Street, Baltimore, Mld.

Jerome Kenney, Field Engineer, 4900 West Hills Road, Baltimore, Md.

Ifon ard Maguire, Chief Engineer, St. Johnsbury, Vt.

G. C. Worthlex, Manager, Scale Division, 600 South Michigan Arenue, Chicago 5, Ill.

Forschner, R. H., Co.: Richard A. Forschner, General Manager, 205 Third Avenue, New Iork 3, N. Y.

Gilbert \& Barker Manufacturing Co.:

Josepf A. Logan, West Springfield, Mass.

C. A. P. Thomas, Sales Engineer, West Springfield, Mass.

Gurley, W. \& L. E.: Franklin G. Williams, Washington Representative, 5514 Nerada Avenue NT., Washington 15, D. C.

Hobart Manufacturing Co.:

Murray W. Craig, Sales Department, Troy, Ohio.

Burns H. Dreese, Genelal Manager, Troy, Ohio.

Hrnest A. Reussevzenn, Chief Scale Engineer, Scale Division, 444 Hoffman Avenue, Dayton, Ohio.

Howe Scale Co.:

Robert A. PARHAM, Branch Manager, 309 East Saratoga Street, Baltimore, Md.

Richard F. Straw, Vice President, Rutland, Vl.

Martin \& Schwartz, Inc.: Jack H. Prause, Vice President and Director of Sales, Mill Street, Salisbury, Md.

Measuregraph Co.: E. A. Powel, Regional Manager, 2306 Poplar Grove Street, Baltimore, Md.

National Store Specialty Co.: Wallace E. Sheaffer, President, Bareville, Pa. Neptune Meter Co.: Walter H. Sieger, Engineer, 50 West Fiftieth Street, New York, N. Y.

Ohmer Corporation: B. C. Palmer, Central District Manager, 939 North Wells Street, Chicago, Ill.

Owen-Illinois Glass Co.: J. D. LAIRD, Quality and Specifications Supervisor, Toledo, Ohio.

Partee Co. : Paul C. Partee, President, Spencerville, Ind. 
Peerless Weighing \& Vending Machine Corporation:

Paul W. Barras. Philadelphia District Manager, 29-28 Forty-first Avenue, Long Island City $1, \mathrm{~N}$. Y.

LeveretT D. Cirambers, President, 29-28 Forty-first Avenue, Long Island City, N. Y.

Penn Scale Mauufacturing Co. Inc. : Srdyey Black, President, 150 West Berks Street, Philadelphia 22, Pa.

Irockwell Manufacturing Co. :

Clatr H. Daugherty, Service Engineer, Du Bois, Pa.

Robert A. Johnson, Sales Engineer, Pittsburgh Equitable Meter Division, 192. Ward Street, Durham, N. C.

H. D. Leiseniring, Sales Manager, Pittsburgh Equitable Meter Division, 400 Nolth Lexington Avenue, Pittsburgh, Pa.

Charles H. Obrock, Sales Engineer, Pittsburgh Equitable Meter Division, Empire State Building, New York, N. Y.

John Pomanersim, Engineering Department, Pittsburgh Equitable Meter Division, 400 Nolth Lexington Arenue, Pittshurgh, Pa.

Sanitaly Scale Co.: W. H. Tougr, District Sales Manager, 106 West Fourth Street, Belvidere, Ill.

Seraphin Test Measure Co.: T. A. Seraphin, President, 1314 North Severth Street, Philadelphia 22, Pa.

Smith, A. O., Corporation:

Wilson Milligan, Area Sales Manager, Meter Division, P. O. Box 500, Succasunna, N. J.

W. G. Moser, Sales Manager, Meter Division, 111: Washington Boulerard, Chicago 7 , Ill.

Stimpson Computing Scale Co.: Frank M. Doyne, Eastern General Distributor, 468 Weaver Street, Larchingint, N. Y.

Streetel Amet Co.: Verne C. Kennedy, Plesident, 4101 North Ravenswood Avenue, Chicago, 111 .

Thatcher Glass Manufacturing Co.: Janes Arraxide, Director, Quality Control, 623 West Water Street, Elmira, N. Y.

Tokheim Oil Tank \& Pump Co.: IVIlliam E. Louthan, Service Manager, 1600 Wabasl Avenue, Fort Wayne, Ind.

Toledo Scale Co.:

STANley Q. BennetT, Manager of Service and Weights and Measures Division, Toledo, Ohio.

Patrick E. Young, District Manager, Box 2107, Raleigh, N. C.

Troemner, Henry :

Eoward J. Fukey, General Manager, 911 Arch Street, Philadelphia $7, \mathrm{~Pa}$.

Charles F. Rosica, Sales Manager, 911 Arch Street, Philadelphia 7 , Pa.

Josepy J. Rosica, Weight Department Superintendent, 911 Arch Street, Philadelphia 7, Pa.

U. S. Slicing Machine Co. :

Byron D. Mrller, Sales Promotion Manager, Standard Computing Scale Division, La Porte, Ind.

MatT D. Ribile, Standard Computing Scale Division, La Porte, Ind.

Union Tank Car Co.: Rarmond L. HiatT, Engineer, 228 North La Salle Street, Chicago 1, Ill.

Veeder-Root, Inc. :

John J. Brannick, Sales Manager, Computer Division, Hartford 2, Conn.

Austin E. McKenver, Sales Representative, Hartford 2, Conn.

D. J. Post, Jr., Vice Plesident, Hartford 2, Conn.

Wayne Pump Co.: T. J. Unkmma, Chief Engineer, Liquid Dispensing Equipment, 513 Tecumsel Street, Fort Wayne, Ind.

Wood, John, Co. :

Louis G. Close, Manager Mid-Atlantic District, Bennett Pump Division, 2127 Nortl Charles Street, Baltimore, MI.

Williax M. Hoxis, Service Mamager, Bennett Pump Division, Muskegon, Mich.

Yale \& Towne Manufacturing Co.:

Oswald S. Carliss, Chief Engineer, Scale Division, Roosevelt Boulevard, I'hiladelphia 15, Pa.

Fred E. RAU, Scale Sales Department, Roosevelt lioulevart, Philadelphia, Pa. 


\section{GUESTS REPRESENTING ASSOCIATIONS, BUSINESS AND INDUSTRY,} AND RAILROADS

American Can Co.: George O. Sampson, Assistant Manager, Research Division, 360 Elizabeth Avenue, Newark, N. J.

American Car and Foundry Co.: Clyde H. Formsbee, Assistant Chief Engineer, Berwilk, Pa.

American Paper Goods Co.: Lloyd W. Vibberts, Production Superintendent, Kensington, Conn.

American Petroleum Institute: James E. Moss, Director, Division of Transportation, 1625 K Street NW., Washington, D. C.

American Seed Trade Association: George B. Smith, P. O. Box 778, Detroit, Mich.

American Trucking Association: Lewis C. KibвeE, Equipment Engineer, 1424 Sixteenth Street, Washington 6, D. C.

Baltimore \& Ohio Railroad: E. Kent Lawrence, General Scale Inspector, Baltimore 1, Mrd.

Bethlehem Steel Co. :

Givilym E. Evans, General Foreman, Scale Repair, Sparrows Point, Md.

James J. Maginnis, Assistant Foreman, Scale Repair, Sparrows Point, Md.

Carnegie Illinois Steel Corporation: CharLes BaUER, Scale Shop Foreman, 328 West Ridge Road, Gary, Ind.

Chicago \& Northwestern Railway : HARrY MAXER, Engineer of Scales and Work Equipment, 400 West Madison Street, Chicago 6, Ill.

Continental Can Co., Inc.: JoHN C. Jennings, Manager Mono Container Sales, 349 Oraton Street, Newark 4, N. J.

Dixie Cup Co.: Clemext G. McBride, Market Research Assistant, Easton, Pa.

Esso Standard Oil Co.:

C. A. Brewi, Manager, L. P. G. Sales, 15 West Fifty-first Street, New York, N. Y.

Logan L. Kennedx, Superintendent, Construction and Maintenance, 500 North Broad Street, Elizabeth, N. J.

.John II. McCцnntock, Manager, Oil Conservation Division, 15 West Fiftyfirst Street, New York, N. Y.

Gasoline Pump Manufacturers Association: G. Denvy Moone, Managing Director, Graybar Building, 420 Lexington Arenue, New York 17, N. Y.

Glass Container Manufacturer's Institute: Nichocas G. CAMERoN, 8 West Fortieth Street, New York, N. Y.

Great Atlantic \& Pacific Tea Co.:

R. G. CARPEN'TER, Neat Packaging Specialist, National Meat Department, 211 West Wacker Drive, Chicago 6, IIl.

W. P. REED, Manager, Weights and Measures Department, 1004 Hemphill Arenue NW., Atlanta, Ga.

Gulf Oil Corporation: JoH N O. Haвicht, Superintendent, Marketing Equipment, 1515 Locust Street, Philadelphia, Pa.

Industrial Research Syndicate: C. A. LindsaY, Director, 1305 Euclid Street NW., Waslington, D. C.

International Association of Ice Cream Manufacturers:

John S. Conner, 1105 Barr Building, Washington 6, D. C.

Ford Young, Attorney, Mills Building. Washington, D. C.

Lily-Tulip Cup Corporation: Robert D. Bergman, Assistant to the President, 122 East Forty-second Street, New York, N. Y.

Liquid Tight Paper Container Association: ARThur W. Howe, JR., Assistant Executive Secretary, 1532 Lincoln-Liberty Building, Philadelphia, Pa.

Liquefied Petroleum Gas Association: H. Emfrson Thomas, Board of Directors, 111 Quimby Street, Westfield, N. J.

National Association of Scale Manufacturers: ARTHUR SANDERs, Secretary, 1129 Vermont Arenue NIV., Washington, D. C.

National Institute of Rug Cleaner's: Norbert J. Berg, Managing Executive, National Institute of Cleaners and Dyers, 909 Burlington Avenue, Silver Spring, IId.

National Retail Grocers Association: Chardes Sicget, President, Siegel Super Market Incorporated, 426 North Sixth Street, Richmond, Va.

National Scale Men's Association: Jonn H. Dow xer, Secretary, 608 South Dearborn Street, Room 2236, Chicago 5. Ill.

Paper Cup and Container Institute, Inc.: Dale H. Eckerman, Executive Director, 1790 Broadway, New York 19, N. Y. 
Phillips Petroleum Co.: Doyte D. ButrorpH, Technical Representative, Bartlesville, Okla.

Pennsylvania Railroad: M. J. J. Harkison, Supervisor of Scales and Weighing, Box 345, Aitoona, Pa.

Safeway Stores, Inc.:

J. A. Anderson, Pricemaker, 1845 Fourth Street NE., Washington, D. C.

Edgar Balshaw, Division Manager, 1845 Fourth Street NE., Washington, D. C.

Frederick G. KaYhoe, Real Estate Manager, 1845 Fourth Street NE., Washington, D. C.

Frank J. Sheenan, Manager Public Relations, 726 Jackson Place NW., Washingtou, D. C.

JosePh W. Upton, Office Manager, 1845 Fourth Street NE., Washington, D. C.

BerT R. WARNer, Advertising Manager, Standard Oil Building, Washington, D. C.

Gibson I. Wright, Supply Manager, 1845 Fourth Street NE., Washington, D. C.

STEPHEN IV. Wright, Manager, Trucking and Warehouses, 1845 Fourth Street NE., Washington, D. C.

Saybolt, J. W., Business Counsellor, 9209 Carlyle Avnue, Surfside, Miami Beach 41 , Fla.

Scale Journal Publishing Co.: Ediru J. Saybolt, Secretary, 1703 Eist Eightyfourth Street, Chicago 17, Ill.

Shell Oil Co.:

Charles H. Bethel, Operations Special Assignment, Box 25, Passaic, N. J.

Lours A. Thommen, Division Engineer, 3706 Eighty-second Street, Jackson Heights, N. Y.

Sinclair Refining Co.: Kenneth W. Birkin, Manager, Automotive Division, 630 Fifth Avenue, New York, N. Y.

Suburban Propane Gas Corporation:

EDward W. Brut, Assistant District Manager, Box 112, Rockville, Md.

Hurlbert R. Bridgewater, District Manager, Box 112, Rockville, Md.

Sutherland Paper Co.:

L. J. Moore, Assistant Manager of Sales, Division A, Kalamazoo 13-D, Mich.

Lewis E. ShIFled, Assistant Advertising Manager, Kalamazoo 13-D, Mich. Thread Institute, Inc.:

JoHn BeLL, Chairman, Legislation Committee, 11 West Forty-second Street, New York 18, N. Y.

Darid Snyder, Executive Director, 11 West Forty-second Street, New York $18, \mathrm{~N}$. Y.

Visking Corporation: Elliot Balestier, Jr., Assistant to President, 6733 West Sixty-fifth Street, Chicago 38 , IIl.

\section{MISCELLANEOUS GUESTS}

Charles G. CRocketT (Retired Weights and Measures Official), 3632 Rolerts Place, Baltimore 24, Md.

George A. Howe, 112 Fourtl Street SE., Washington 3, D. C. 


\section{CONTENTS}

Officers and Committees

\section{FIRST SESSION-MORNING OF TUESDAY, MAY 23, 1950}

Address by Dr. E. U. Condon, Director, National Bureau of Standards, and President, National Conference on Weights and Measures.............. Abstracts of State Reports:

California, by James E. Brenton, Chief, State Bureau of Weights and Measures

Connecticut, by Frank M. Greene, Deputy State Food and Drug Commissioner

District of Columbia, by James G. Dance, Deputy Director of Weights, Measures, and Markets

Florida, by Nalls Berryman, Supervisor, State Division of Weights and Measures

Hawaii, by B. K. Cummins, Chief Inspector of Weights and Measures, City and County of Honolulu

Illinois, by John J. Levitt, State Superintendent of Standards ...........

Indiana, by Cleo C. Morgan, Sealer of Weights and Measures, City of Gary

Iowa, by James W. Reese, Supervisor, State Division of Weights and Measures

Kansas, by J. Fred True, State Sealer of Weights and Measures........

Kentucky, by George L. Johnson, Director, State Division of Weights and Measures

Louisiana, by A. J. Mayer, Director, State Division of Weights ard Measures

Maine, by James A. Boyle, Deputy State Sealer of Weights and Measures.

Maryland, by A. Morton Thomas, Director of Inspections and Licenses, Montgomery County

Massachusetts, by John P. McBride, State Director of Standards and Necessaries of Life.

Michigan, by Miles A. Nelson, Chief, Bureau of Marketing and Enforcement

Minnesota, by Erling Hansen, Supervisor, State Department of IVeights and Measures

Mississippi, by Allen McCluer, Chief Inspector, Department of Agriculture

Missouri, by Joseph A. Bernard, Commissioner of Weights and Measures, City of St. Louis

Nebraska, by W. W. Gray, Chief Inspector of Weights and Measures, City of Omaha

Nevada, by Wayne $\vec{B}$.

New Hampshire, by Albert H. Dittrich, Commissioner of Weights and Measures

New Jersey, by Joseph G. Rogers, Deputy Superintendent, State Division of Weights and Measures

New York, by Clement A. Baker, Director, State Bureau of Weights and Measures

North Carolina, by C. D. Baucom, State Superintendent of Weights and

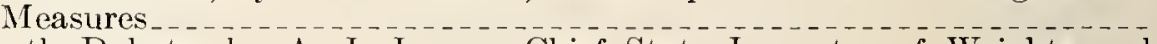

North Dakota, by A. J. Jensen, Chief State Inspector of Weights and Measures

Ohio, by V. D. Campbell, Deputy State Sealer $\ldots \ldots$

Oklahoma, by T. C. Beck, Assistant Director, Marketing Division_......

Pennsylvania, by Spencer H. Seighman, Assistant Director, State Bureau of Standard Weights and Measures

Puerto Rico, by José R. Rivera, Chief Engineer, Public Service Commission. 
Abstracts of State Reports-Continued:

Page

Rhode Island, by Edward R. Fisher, State Sealer of Weights and Measures.

South Carolina, by Chovine R. Sprott, Deputy Commissioner of Agriculture

Texas, by O. A. Firkland, State Inspector of Weights and Measures

Utah, by E. C. Westwood, Sealer of Weights and Measures, City of Salt

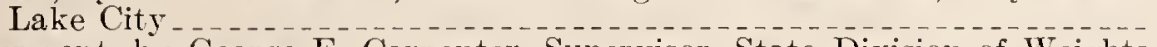

Vermont, by George E. Carpenter, Supervisor, State Division of Weights and Measures_._._._._._._._._._._._.

Virginia, by R. D. Thompson, Supervisor, State Section of Weights and Measures

Washington, by Donald WT. Turnbull, Supervisor of Licenses and Standards, City of Seattle

Wisconsin, by George W. Warner, Supervisor, State Division of Weights and Measures

Wyoming, by Charles $\mathrm{H}$. Oakley, State Inspector of Weights and Measures

Abstracts of Reports of Representatives of State and Regional Associations of Weights and Measures Officials:

California Association of Weights and Measures Officials, by Charles Morris Fuller, Sealer of Weights and Measures of Los Angeles County, Calif

Connecticut Sealers' Association, by Frank M. Greene, Deputy Commissioner, Food and Drug Commission of Connecticut _................

Illinois Weights and Measures Association, by John J. Levitt, State Superintendent of Standards of Illinois

Indiana Association of Inspectors of Weights and Measures, by James A. Hilgemann, Inspector of Weights and Measures of Fort Wayne...

Massachusetts Weights and Measures Association, by Frank Draghetti, Sealer of Weights and Measures of Agawam

Michigan Association of Weights and Measures Officials, by James H. Hitchings, Inspector of Weights and Mcasures of Detroit............

New Jersey Weights and Neasures Assosiation, by Winfield K. Thompson, Assistant Superintendent of Weights and Measures of Cumberland County

New York State Weights and Measures Association, by Guy T. Parsons, Sealer of Weights and Measures of Delaware County

Northwest Weights and Measures Association, by A. J. Jensen, Chief Inspector of Weights and Measures of North Dakota_.............

Ohio Sealers' Association, by Leon E. Bates, Deputy Sealer of Weights and Measures of Wood County

Pennsylvania Association of Inspectors of Weights and Measures, by Spencer H. Seighman, Assistant Director, State Bureau of Standard Weights and Measures of Pennsylvania

Rhode Island Weights and Measures Association, by Edward R. Fisher, Sealer of Weights and Measures of Rhode Island

Southern Weights and Measures Association, by John I. Moore, Supervising Inspector of Weights and Neasures of North Carolina

Texas Weights and Neasures Association, by O. A. Kirkland, State Inspector of Weights and Measures of Texas

Virginia Weights and Measures Association, by Conway C. Munday, Chief, Bureau of Weights and Measures of Richmond.

Report of the National Conference Committee on Legislation, Presented by Rollin E. Neek, Chairman

A Report from the National Scale Men's Association, by J. H. Downer, Secretary, National Scale Men's Association.

Duties of an Inspector in a Service Station, by $\mathbf{W}$. B. Heaslip, Supervising Inspector of Weights and Measures, City of Detroit, Mich

Duties of an Inspector in a Retail Food Store, by F. M. Greelle, Deputy Commissioner, Food and Drug Commission, State of Connceticut..

\section{THIRD SESSION-MORNING OF WEDNESDAY, MAY 24, 1950}

Report of the Special Conference Committce on Uniform Regulations, Presented by R. D. Thompson, Chairmall

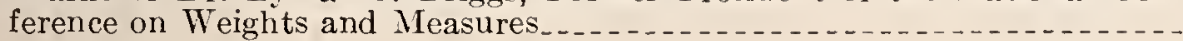


Developinents in Elcetronic Weighing, by C. L. Richard, Supervisor of Scales and Weighing, Packers and Stockyards Division, U. S. Department of Agriculture

Report of the National Confcrence Committee on Trading by Weight,

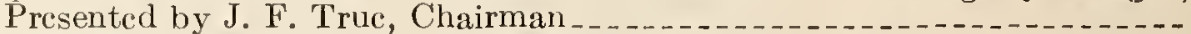

Testing Equipment for LPG Measuring Deviccs:

Remarks of J. E. Brenton, Chief, Bureau of Weights and Measures, State of California

Remarks of Nalls Berryman, Supervisor, Weights and Measures Division, State of Florida

Remarks of F. W. Hessce, Scnior Chemist, Weights and Measures,

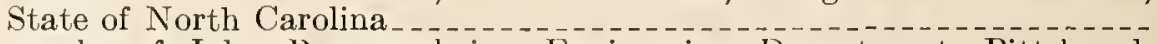

Remarks of John Pommersheim, Engineering Department, Pittsburgh Equitable Meter Division of Rockwell Manufacturing Company....

Discussion on the Four Preceding Papcrs

Tour of Bureau of Standards Laboratories.

FOURTH SESSION-MORNING OF THURSDAY, MAY 25, 1950

Report of the National Conference Committee on Specifications and Tolerances, Presented by J. P. McBride, Chairman, and Discussion Thereon--

Section on General Code...........

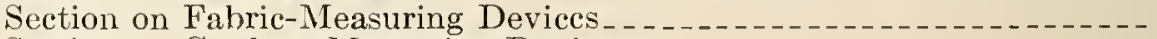

Section on Cordage-Measuring Devices

Section on Liquid-Measuring Devices _............................

Section on Greasc-Measuring Devices

Section on Scales

Prepackaged Perishable Commodities:

The Marketer's Viewpoint-Remarks of R. G. Carpenter, Meat Packaging Spccialist, The Great Atlantic \& Pacific Tea Company

The Marketer's Viewpoint-Remarks of Charles Siegel, National Association of Retail Grocers_._._.

Informative Labeling and Enforecment Procedures-Remarks of $\mathrm{H}$. E. Howard, Supervisor of Weights and Measures, City of Miami, Fla.-

The Responsibilities of the Official to his Weights and Measures Association, by J. R. Jones, Commissioner of Agriculture, State of South Carolina

Report of the National Conference Committee on Weights and Measures Education, Presented by J. T. Kennedy, Chairman_................

\section{FIFTH SESSION-AFTERNOON OF THURSDAY, MAY 25, 1950}

Problems Involved in Setting up a New Weights and Measures Organization:

Administration-Remarks of T. C. Beck, Assistant Director, Marketing

Division, State of Oklahoma
Training-Remarks of A. J. Mayer, Director, Division of Weights and Measures, State of Louisiana

Weights and Measures, State of Kentuckyson, Director, Division of

Wcighbeam Maintenance, by M. J. J. Harrison, Supervisor of Scales and Weighing, Pennsylvania Railroad

A Program of Livestock Scalc Testing, by Erling Hansen, Supervisor, Department of Weights and Measures, State of Minnesota

The Laws and the Case Book, by Mrs. Kathryn M. Schwarz, AttorneyEditor, Office of Weights and Mcasures, National Bureau of Standards_- 120

Report of the National Conference Committee on Methods of Sale of Commodities, Presented by J. F. Blickley, Chairman, and Discussion Thereon -

SIXTH SESSION-MORNING OF FRIDAY, MAY 26, 1950

Open Forum:

Increasing the Value of the National Conference to Weights and Measures Officials-R. W. Smith, National Bureau of Standards_._._._ 133

The Testing of Wheel-load Weighers-V. D. Campbell, Ohio_..... 133

Basis Weights for Paper and Textiles-R. S. Cleveland, National Bureau of Standards.

Charges for Rug Cleaning-G. H. Leithauser, Baltimore, Md..... 
Open Forum-Continued

Calibration of Tank Cars-H. H. Russell, National Bureau of Standards_ 145

Wholesale Labeling of Meat Products-Dr. J. R. Scott, Bureau of Animal Industry, U. S. Department of Agriculture

Improving the Service of the NBS Office of Weights and Measures to Officials and Manufacturers-W. S. Bussey, National Bureau of Standards_._. _..._._.

Strain-load Tests and Build-up Tests-S. H. Christie, Jr., New Jersey 156

Vapor Meters-F. C. Morey, National Bureau of Standards _._._. 159

Measure-containers and Non-measure-containers-George W. Warner, Visconsin ... . . _ .

Additional Topies Brought up by Officials and by Associate Members of the Conference

Report of the National Conference Committee on Resolutions, Presented by J. J. Levitt, Chairman:

Appreciation to Director and Staff of the National Bureau of Standards _ 164

Appreciation to Cooperating Officials _._._._._._._.

Appreciation to Those Participating in Program

Appreciation to the Press and Radio

Appreciation to Management of Headquarters Hotel

In Memory of Deceased Members _._.

In Memory of Harry M. Roeser

On the Retirement of A. J. Jensen... 165

On Budgetary Procedure

On the Testing of Railway Track Seales

On the Basis of Computation for Pricing Charts _._.

Report of the National Conference Treasurer, George F. Austiu, Jr_.... 168

Report of the National Conference Committee on Nominations, Presented

by R. E. Meek, Chairman, and Election of Officers_._._. 168 



\title{
REPORT OF THE THIRTY-FIFTH NATIONAL CONFERENCE ON WEIGHTS AND MEASURES
}

\author{
SPONSORED BY THE NATIONAL BUREAU OF STANDARDS, AND HELD \\ AT THE WARDMAN PARK HOTEL, WASHINGTON, D. C., MAY 23, 24, 25, \\ AND 26, 1950
}

FIRST SESSION-MORNING OF TUESDAY, MAY 23, 1950

(The Conference was called to order at 10:15 a. m. by J. T. Kennedy, Vice President of the Conference.)

ADDRESS BY DR. E. U. CONDON, DIRECTOR, NATIONAL BUREAU OF STANDARDS, AND PRESIDENT, NATIONAL CONFERENCE ON WEIGHTS AND MEASURES

Gentlemen, the first thing that I want to do is to welcome you once again to Washington, to this our Thirty-fifth Annual-it is supposed to be annual, but it has had a few breaks in it, as you know, but not through our fault-Conference on Weights and Measures.

I want to make a rather informal report to you. We regard you people as our best friends scattered out through the States and cities, and while our principal contact with you is in the fields concerned with your own particular day-to-day work, on weights and measures enforcement, I thought it might be of some interest if I took a few moments to give you a general report on some trends and developments in the Bureau of Standards as a whole.

As you know, the Bureau started out primarily having been established as a Bureau of Standards in the narrow seuse of an agency responsible for uniformity of physical measurements. That, of course, at the outset goes somewhat beyond the scope of what we associate with weights and measures administration work in a narrower sense, because it involved considerations of uniformity and scientific accuracy and standardization in many fields of scientific measurement such as temperature and electrical quantities, and optical properties, light intensity, and a great many other things besides the usual weights, measures, and volumetric capacity measurements.

Over the years, as you also know, the Bureau has expanded its work so that it includes a great deal of commodity testing work and specification writing for supplies for the Federal Govermment. That service reflects itself out to the State and municipal govermments too, through their procurement agencies, many of whom rely extensively on the Federal specifications that are drawn up for purchase of Federal supplies.

But perhaps a larger activity than that results from the fact that the Bureau has become quite a research and development agency doing fundamental research in the fields of physical sciences and also in the matter of developing specialized equipment needed by the Federal Government, especially in those cases where peculiar research services 
are required, as in the fields of specialized military material, or where the situation is such that the item in question is not attractive to private industry, because however important it may be to the Government, the particular market for the product that results is so small as not to be worth while for a private firm.

In the aggregate the kinds of services rendered by the Bureau, especially including military things, have now become so great that the budgetary amount of it is somewhat greater than the budget directly appropriated to us by Congress. Whereas we are getting about 9 million dollars a year to run the Bureau from Congress, we are doing about 10 million dollars or 11 million dollars a year of work for other agencies, most of which is military, or closely allied to military needs, like work for the Atomic Energy Commission.

I thought you would like to have that general perspective because I know it has been a characteristic of our meetings in the past that we get so immersed in the problems that are peculiar to our own interests in this Conference that you don't get much of a picture of what else is going on in the Bureau.

The military program, of course, is one that is of great importance, probably at all times, but especially in these times when people are so concerned about the fact that peace seems to be a rather elusive thing after all. My own view is that we shouldn't get into a state of excitement or frenzy about the possibility of war, but the possibility of war is always with nis. We should, in as sober and serious and responsible a way as possible, do a solid job of being prepared for it without losing our heads or getting excited or worried.

In the military field we have in the Burean major responsibility for one of the guided-missile projects for the Navy. We hope to have a new missile ready for the fleet in a couple of years.

We also have the complete responsibility for the proximity fuse work for nonrotating missiles for the armed forces altogether. Proximity fuses, for those of you who are not familiar with them, are devices that make it possible that a shell, or anything containing a high explosive, will sense the nearby presence of the target and explode without actually coming in contact with it. That has the effect that you can do damage without making a direct hit. We have the responsibility for all of that development for the armed forces for nonrotating projectiles which, of course, includes guided missiles. So we have some rather major responsibilities.

Going with this growth of the Bureau in these activities and with the general feeling that there should be more and more decentralization from Washington of Government agencies in general, I want to announce to you that we are moving out-we are not moving the entire Bureau but we are extending our activities outward to the States in the West.

We are in the process of acquiring a 220-acre site at Boulder, Colorado, about 30 miles from Denver, for development of a second site for the Bureau of Standards so that some of our facilities and work will be carried on there in the future as well as here. Just how that will proceed in detail, of course, nobody knows. But this site development will be initiated during the next year or two by the development of a 4.5 million dollar laboratory devoted to radio fre- 
quency measurements and radio standards, and studies on the propagation of radio waves at large distances.

This will be helpful to the rest of the Bureau in that the radio people are now taking up so much space in our existing facilities that if we can get rid of them, life will be more comfortable for the people who are now being elbowed out of space by them.

I think that is perhaps enough time to devote to this broad general review, other than to say that I am very happy that you find time on the program of this Conference to devote some of it to visiting some of the laboratories of the Bureau. I hope that not only on this occasion but on occasions when you individually are in town on other business, you will find time to get more acquainted with our laboratory work.

We are making a few organizational changes at the Bureau for the next fiscal year. One which is of most direct concern to this group is the fact that our heavy scale work, which is nearly all railway track scale work, is going to be combined with the Office of Weights and Measures under Ralph Smith. The idea back of that is that the work is very similar in character to the work of the Office of Weights and Measures in cooperating with the State and local jurisdictions. This work, as you know, has meant operating two railroad cars, specially built with weights, for testing railway track scales. I am sorry to say that one of these is so old and in such bad condition that it will have to be condemned pretty soon before somebody condemns it for us. Then we will carry on as best we cau with one such car and make a study as to whether it is really essential to have two.

I would like to invite the Conference here to give a little thought to this question of the railway track scale matter, and give us, especially Ralph Smith and Mr. Russell, the benefit of your own comments and suggestions. As I see the matter, it is one that, in strict logic, ought to be in the hands of the State and local jurisdictions; that is to say, it is a question of checking up on the accuracy and validity of the railway track scales. The only reason that I know of for our handling it instead of you is-I can think of two: One is that it is legitimate to think of the Federal Government getting into this picture, perhaps more so than otherwise, because the railway track scales are really controlling interstate commerce as well as commerce within the States, and, secondly, for local communities or States to invest in such testing equipment, the cost would be considerable.

We find that a fairly satisfactory service for the whole country has been operated in the past with only two test cars. I think it would be conceded it would be foolish then for the 48 States to engage in such matters. But it is so closely tied up with the responsibilities of the State officers that I would like the matter to get some attention from you in the planning of it, so as to make sure that we are doing what you want us to do, and not doing what you don't want us to do, and in general so that the whole matter is handled in a properly coordinated way as between the Federal interest in the matter and the State and local interests in the matter. I throw that out as one of the things that I hope formally or informally you will have time to consider during this Conference.

I would like to mention briefly the fact that I had a very exciting experience during the month of January, having been invited out to 
visit India by the Indian Govermment, to visit some of theil scientific laboratories, where I took part in the formal dedication of their new national physical laboratory at Delhi. I have a wonderful impression of the enthusiasm and verve and vigor with which they are taking their independence seriously and proceeding to go about the business of modernization and development of their comntry.

This is not to minimize the great difficulties that they are confronted with economically, a great problem of over-population, and the special problems concerning the separation between India and Pakistan; but they are in the process of building up a clain of about a dozen national laboratolies, the aggregate of which would be about the equivalent of our Burean of Standards except that two of them are deroted to food and biological subjects. Out of the 10 of them, 8 play the role that our Burean of Standards plays, and the other 2 are analogous to Government agencies not part of the Bureau of Standards. They are engaged in the process of trying to set up a weights and measures administration on a truly national basis. Thele has never been anything in the way of a really thorough-going checkup.

If you think we have complicated problems, you really ought to listen to some of theirs, because they have the most chatic collection of special local weights completely undefined and a different kind of weight for almost every commodity that you can think of. If you go over the hill into the next valley you get a different set of units. 'They are very anxious to remedy that situation.

When I came back I discussed this with Mr. Ralph Smith. $\mathrm{He}$ kindly prepared a special memorandum about how we do it here, which isn't perfect in all respects, as we know, but at any rate we have had some experience. Tre have sent it over to them as a basis for their studies of their improvements.

About 2 years ago President Truman established by Executive Order an Inter-departmental Committee on Scientific Research and Development. The idea of it was to take account of the fact that we have agencies engaged in scientific research in practically every department of the Govermment. 'They have problems in common. The point was to get them together to understand things, to thrash out those problems and get some kind of uniformity of action proposed by conference methods such as we follow here. without particularly giving this body any authority to enforce anything.

Within the working of that committee there has been, as usually happens, a group of subcommittees set up. I have the honor to be chairman of one that is called the Subcommittee on Budgetary Procedures. The have been meeting this year. Out of this we are getting a lot of valuable experience. The attitudes of the different agencies of the Govermment-which have just grown up by chance-are such that the vocabulary isn't the same. What some call a project, others call a program, others call a task, and still others call a mission. How they account for overhead and how they estimate what is needed and so on is just a grand jumble of hodgepodge that is well-meaning, it isn't intended to deceive anybody, but different people have just grown up with different habits in such a way that it is wholly incomprehensible.

We have been discussing this at great length in attempting to get agreement on points of view on how best to do that. This activity 
has been so valuable that the idea occurred to me-and I want to throw it open to you for your own consideration-that perhaps this Conference ought to have something like a committee on budgetary procedures, the idea of which would be to consider how we really do estinnate what the legitimate needs are for veights and measures enforcement activities, weights and measures administration activities, in each jurisdiction.

I think it has been pointed out here in the past by various speakers that the situation is actually quite uneven from city to city and State to State. I think we want to guard against any idea that we are looking for tricky bits of technique as to how we can get our budgets higher, and against those forces of evil that are trying to keep them lower and lower. There nust be a sober answer to the question of what does a State or city really require for an effective administration. What budget does it take, how many officers per 100,000 popnlation or per number of retail establishments or any other measure do you want, and what kind of men should they be, and what should their equipment be? Certainly this sort of thing is sonething that we ought to give attention to, so that we can see how we can do a better job. I am sure that in many instances the doing of a better job will call for more of a budget, and that we ought to see ways in which we can persuade onr government officials locally to give us more budget so that we can really show that a better job can be done.

It seems to me that just as we find that the different scientific agencies of the Goverment have problems in common as to how to work up and present a budget, so there must be a great deal of experience, an interchange of experience, that could be given by officials of different jurisdictions on their experiences and difficulties that would assist each other in working ont better ways of presenting it.

I suggest, therefore, to you, that we consider-and I will ask you to give me your opinions later in the Conference at some time, or give them to Mr. Sinith-that we perhaps should establish a standing committee on budgetary procedures for dealing with those matters. One possibility is that this matter be dealt with by the Committee on Weights and Measures Education, because, after" all, the problem of budget is the problem of educating the government oflicials that are above us as to needs. But just how this is to be handled is a separate question, and I would like your views on it.

As you know, Handbook H44, which represents a revision of the specifications and tolerances and regulations for commercial weighing and measuring devices, was adopted here last year and became available from the printer in October, 1949. The sales demand we had underestimated, so that the book was out of print for a while. But it has now been reprinted. This book I am sure all of you are familiar with, but I will exhibit one here in case you are not.

The report of the Thirty-fourth National Conference, last year's Conference, became available from the printing office in January of this year, as Miscellaneous Publication 195, and copies have been distributed to the persons that were registered at that meeting.

Another publishing activity in which the Bureau has had direct concern is the revision of the old compilation of all the Federal and State weights and measures laws. 'This has been going on in the Office of Weights and Measures and has just been sent off to the 
printer so that later in this year sometime the finished book should be available. It might possibly be delayed until next year, the next calendar year, on account of other printing jobs being ahead of it. I think it is quite likely to be available this fall. This book was last revised, I think, about 1926.

There is being printed as a Bureau circular a summary and tabulation of the State package-marking requirements. There is continuing demand for this information, and the complete information which this Circular contains is expected to be helpful to many. The main table in this Circular clearly demonstrates the opportunity which exists in many States to strengthen their laws requiring that packages of all commodities, not merely packages of food, carry declarations of net content. This example has already been set by 20 jurisdictions that now have this requirement.

Mr. Smith has been working on-and has made considerable progress on-the preparation of another Handbook which will be a companion volume to $\mathrm{H} 37$ and will be entitled "Testing of Measuring Equipment, a Manual for Weights and Measures Officials." We hope that will be useful to you.

Also in course of preparation is a weights and measures casebook which was mentioned here before, and the completion of which has been delayed by prior activity on the compilation of the laws. Mrs. Schwarz, the attorney on the staff of our Office of Weights and Measures, will give a report on this casebook and other matters connected with it later in this program.

I have to announce, both with regret and pleasure, that $\mathrm{Mr}$. R. J. Neale, who joined our staff last year, has already left us. I regret that he has left "us, but he has gone to a better job in the livestock branch of the U.S. Department of Agriculture. Mr. Neale joined the Office of Weights and Measures but soon found an opportunity for a better position, so he left us. But it is in a closely related field where it will be of help to this work.

There have been some changes in personnel at the State level since our last meeting which should be reported for your information. Mr. W. P. Reed, of Georgia, has resigned to accept a position with the A \& P Company. For the time being $\mathrm{M}_{1}$. A. D. Harris, Chief of the Division of Food, Feed, Seed, and Weights and Measures of the Georgia Department of Agriculture, will handle the duties formerly assigned to Mr. Reed. In Louisiana, Mr. A. F. Chappuis has been succeeded by Mr. A. J. Mayer as Director of the State Division of Weights and Measures. In New Hampshire Mr. A. H. Dittrich has succeeded Mr. J: J. Hensen as State Commissioner of Weights and Measures. In Oregon, $\mathrm{Mr}_{\mathrm{r}}$. Walter Steele is the new Deputy Sealer of Weights and Measures, having succeeded Mr. C. R. Jester. In South Dakota, Mr. Anton Prestwick has been succeeded by Mr. K. I. Gross as Director of the Division of Inspections of the State Department of Agriculture.

Getting back to our legal questions again, the Office of Weights and Measures during the past year, and always at the request of State officials, has made recommendations or submitted proposed bills for improving or establishing weights and measures supervision in Omaha, Neb., Denver, Colo., the State of Colorado, the State of Arkansas, the State of Arizona, and the State of New Mexico. 
I am happy to report that a bill for establishing a comprehensive system of supervision in the State of Kentucky has been enacted into law, and this will become effective as of July 1 of this year. Efforts to enact similar legislation in the State of Mississippi have been renewed. As this is written, the legislature has not taken final action on the weights and measures bill. ${ }^{2}$

There has been a very gratifying increase in the amount of specialized testing equipment put into service throughout the country. WVe have word of new volumetric provers in the District of Columbia, Baltimore, Md., Madison, TVis., and the States of Indiana, Maine, New Mexico, and Rhode Island; and of new vehicle-scale testing equipments in Idaho, Illinois, Indiana, Kansas, Kentucky, Maine, North Carolina, New Jersey, Ohio, South Carolina, Texas, and Wyoming. Special equipment for testing grain hopper scales has been put into service in Texas. A program for testing prescription scales and weights has begun in Indiana, and a survey in this field has been made in Texas.

The Indiana Division of TVeights and Measures has a new laboratoly and new laboratory equipment. We learn of some instances of increased appropriations permitting the employment of additional personmel. A salutary trend is noted in the increased amount of attention to programs of practical training for weights and measures officials; this is discussed in some detail in the report of the Conference Committee on Weights and Measures Education.

I commend the action of those States which have already promulgated Handbook H44 without major change and urge similar action for jurisdictions which have not taken this step. The formal promulgation of these codes is strongly recommended in preference to mere informal adherence to the requirements. Formal recognition is the stronger action and greatly strengthens our pattern of uniformity throughout the country.

A few weeks ago we sent out a letter of inquiry to States from which we had not already heard regarding the promulgation of the H44 codes. Not all States have replied. We do have information on 38 jurisdictions. I think this is a matter of such importance as to warrant a report on the results of the inquiry.

First we can account for six States as having no State weights and measures organization in the general sense. So action there is not to be expected. The H44 codes, either in complete or essentially complete form, are reported as having been actually promulgated in 13 States, and similar promulgation sometime during 1950 or at the latest within the next year, is said to be in process or planned in 13 additional jurisdictions. By "essentially complete form" it is meant that relatively minor changes from or additions to the $\mathrm{H} 44$ text have been introduced in some cases to conform to existing statutory requirements or for other compelling reasons, or that some codes have been deleted entirely because of statutory requirements limiting the authority of the weights and measures officers to certain fields of activity or proscribing certain classes of equipment.

The majority of the States "planning" promulgation say that they are unofficially using the $\mathrm{H} 44$ codes. In addition to the jurisdic-

2 See abstract of State report from Mississippi, page 13. 
tions already mentioned, 6 States reported that $\mathrm{H} 44$ is now in use. 'Two States report that $\mathrm{H} 44$ is in partial use, without giving definite indication of plans for early official promulgation. 'Two more States report that $\mathrm{H} 44$ will be promulgated in part. One State advised that there are no present plans for promulgation and one official states definitely that promulgation will not be made. Replies have not been received from 5 States.

I have some comments here about people saying why they would or would not use it. I will omit the favorable ones and jump to the unfavorable ones as more interesting. It is more interesting to be kicked around wather than to be told you are a fine fellow.

In one State reporting partial present use of $\mathrm{H} 44$, the official stated that while uniformity is very desirable from the manufacturers' standpoint, State laws or local conditions make uniformity "impossible or of questionable value." I can well molerstand that a 100percent uniformity may never be realized, but I fail to see why uniformity shonld be thought of as of "questionable value."

The official who rather definitely said that the H4t material would not be promulgated, an oflicial who has never attended, so far as we know, this National Conference, took particular exception to the National Conference tolerances on eqnipment and criticized these as being too liberal. He suggested that these toler"ances "must have been originated by someone whose weights and measures experience has been secured with his feet under a desk and not by those who are engaged in doing the day-by-day work in this field." He went on to say that so long as the Conference recommendations are "so unrealistic" he will continue to exercise his prerogative under the law which requires him to adopt "reasonable rules and regulations on variations and toler'ances".

Contrary to this expressed opinion, I believe that the very gratifying general acceptance of the National Conference specifications and tolerances stems largely from the fact that these technical recommendations have been developed by the joint action of members of this Conference which is composed of men who are engaged in cloing and supervising the day-by-day work in the field. I think plenty of us wish we had our feet under a desk a few more hours a day than we do.

Not all of the ofticials reporting on the promulgation of the codes accepted the invitation to comment on the general question of uniformity of code requirements among the States.

Summarizing with respect to the $\mathrm{H} 44$ codes, it can be said that of the 43 jurisdictions, including the District of Columbia, in which general weights and measures programs are being carried on, the H44 codes have been promulgated or will be promulgated probably within one year or less, or they are now in use in a total of 32 jurisdictions. In four additional jurisdictions they will be promulgated in part or are presently in partial use. In two additional jurisdictions there is no indication that promulgation will be made. Replies have not been received from five jurisdictions.

Notwithstanding the minority viewpoint illustrated by some of the objections which I have reported to you, I am gratified and I think the Conference can be well pleased by the general acceptance of the Conference recommendations. 
Appointments are required for some, but not all of the standing committees of the National Conference. On the Committee on Specifications and Tolerances the term of R. W. Smith expires this year. I am appointing as his successor, for a 5-year term, W. S. Bussey, Assistant Chief of the Office of Weights and Measures. Thus the Bureau of Standards liaison with this important committee will be maintained. This appointment necessitates Mr. Bussey's removal from the Committee on Weights and Measures Education; to replace him on that committee, I am appointing, for a 5-year term, C. M. Fuller, the Sealer of Weights and Measures of Los Angeles County, California. No additional appointment is required for the Committee on Education becanse no terms expire this year.

On the Committee on Methods of Sale of Commodities, the term of J. A. Boyle, of Maine, expires this year. No replacement is needed because $\mathrm{Mr}$. Boyle's retirement will still leave the Committee with the standard membership of five. You recall we are in the process of making an adjustment on the size of the Committees by this means.

On the Committee on Legislation, the term of F. C. Yarbrough, of Charlotte, N. C., expires this year. To bring the membership of this Committee to the standard number of five, and to avoid reducing the terms of the hold-over members, I am appointing, for a 2-year term, C. H. Oakley, State Inspector of Weights and Measures of Wyoming. On the Committee on Trading by Weight there will be two vacancies. The term of J. E. Brenton, of California, expires this year, and H. K. Thatcher, of Arkansas, is no longer in the service of that State. I an appointing for the 5-year term as Mr. Brenton`s successor, J. J. Levitt, Superintendent of Standards of Illinois, and as successor to Mr. Thatcher, for a 1-year term, I am appointing F. G. Cesar, Director of the Marketing Division of Oklahoma.

I have to announce with respect to the Committee on Uniform Regulations, that last January the Chairman, J. W. Reese of Iowa, asked to be relieved of the Chairmanship because of the press of official duties and the condition of his health. This request was granted. At that time I appointed another member of the committee, R. D. Thompson, of Virginia, as Chairman. In view of the circumstances, I propose that this special committee be granted another year to complete its assigmment.

As committees to act during the 35th National Conference, I make the following appointments:

For the Committee on Nominations : R. E. Meek, of Indiana, Chairman; Nalls Berryman, of Florida; J. A. Boyle, of Maine; J. A. Bernard, of St. Louis, Mo.; Alfred Lirio, of Cumberland County, N. J.; W. A. Masinda, of Tolland County, Comn. : and G. W. Warner, of Wisconsin.

For the Committee on Resolutions: J. J. Levitt, of Illinois, Chairman; F. M. Greene, of Connecticut: G. L. Johnson, of Kentucky; IV. A. Kerlin, of Alameda County, Calif.; William Kirk, Jr., of Xiassau County, N. Y.; R. IV. Searles, of Medina County, Ohio; and S. H. Seighman, of Pennsylvania.

Gentlemen, this concludes the opening remarks that I had planned to make to you. I again am happy to see so many here this year and to note the progress that is being made in our field of work. I am 
happy that you are planning to liold some sessions at the Bureau of Standards and to devote some time to visiting our laboratories. I extend to you a standing invitation, one and all, to visit us at any other time that you happen to be in the city, or to call on us in any way that we can work together in the same, I hope, mutually satisfactory way that las marked all the relations between the Bureau of Standards and the State and municipal jurisdictions in the years past.

The Ciramman. At the Thirty-fourth National Conference the following resolution was adopted:

Resolved, That during the opening session of each annual Conference on Weights and Measures, time be allotted to permit proper memorial service in eulogy in memory of those who have been called by our Creator.

The Secretary of the Conference has received no requests for memorials occasioned by deaths among the membership of the Conference, and-accordingly no arrangements for memorials have been made in advance of this meeting. However, before proceeding, the Chair extends to any active or associate member of the Conference here present, the privilege of the floor to speak briefly in eulogy of any member of our organization who may have passed away since our previous meeting. Does anyone wish to take advantage of this opportunity to speak?

(There was no response to the foregoing invitation of the Chairman.)

\section{ABSTRACTS OF STATE REPORTS *}

\section{CALIFORNIA}

\section{By James E. Benton, Chief, State Bureau of Weights and Measures}

Mr. Brenton reported the adoption of a code relating to liquefied petroleum gas, and a code covering farm tanks for the storage and measurement of milk. He stated that copies of these codes are available upon request.

\section{CONNECTICUT}

\section{By Franix M. Greene, Deputy State Food and Drug Commissioner}

Mr. Greene reported that but few changes were made in the Connecticut weights and measures organization during the year and that the only weights and measures legislation enacted was a brief amendment to the Milk Bottle Law relating to the manufacturer's identification. Specifications, tolerances, and regulations are being revised to conform with Handbook H44.

\section{DISTRICT OF COLUMBIA}

\section{Bx James G. Dance, Deputy Director of Weights, Measures, and Markets}

Mr. Dance reported the successful prosecution of 28 short-weight cases. During the coal strike, the Director of the Department was called upon to act as Chairman of the Fuel Coordinating Committee. A series of discussions has been instituted as a persomnel training program.

${ }^{3}$ For convenience of reference, these abstracts are presented herein in alphabetical order by States, regardless of the actual order of presentation at the meeting. 
FLORIDA

\section{By Nalus Berryman, Supervisor, State Division of Weights and Measures}

Mr. Berryman reported that the Florida department has 16 specially trained men who test weighing and measuring devices, and 40 general inspectors who devote about lialf of their time to the testing of gasoline and kerosene pumps and checking package weights. Two men are employed in the weights and measures laboratory in Tallahassee. Florida is now in the process of promulgating Handbook H44 codes, with a few minor changes.

\section{HAWAII}

By B. K. Cummins, Chief Inspector of Weights and Measures, City and County of Honolulu ${ }^{4}$

Mr. Cummins, reporting for the City and County of Honolulu, said that the County covers the entire 600 square miles of the Island of Oahu. The population is about 300,000 exclusive of military persommel. The City-County weights and measures staff consists of 3 men. $\mathrm{Mr}$. Cummins cited insufficient appiopriations as the biggest hindrance to progress in weights and measures administration. He advocated the adoption of the $\mathrm{H} 44$ Codes and uniform laws in the Territory.

\section{ILLINOIS}

\section{By JoHN J. Levi'T, State Superintendent of Standards}

Mr. Levitt reported one additional vehicle-scale test truck, making a total of three. He announced with regret the resignation of Mrs. Vivienne Kettlekamp, Secretary in the Weights and Measures Division, and Secretary of the Illinois Association, to become effective sometime during the coming year.

\section{INDIANA}

By Cueo C. Mongan, Sealer of Weights and Measures, City of Gary

Mr. Morgan reported that the State Division is now occupying new office and laboratory facilities. State and local offices have increased their personnel, and much new equipment has been secured, including a new vehicle-scale test truck and three 100 -gallon portable meter-testing units. The Handbook $\mathrm{H} 44$ codes have been adopted.

IOWA

\section{By James W: Reese, Supervisor, State Division of Weights and Measures}

Mr. Reese reported that his division is now operating six trucks weighing 16,000 pounds, one truck weighing 24,000 pounds, and a new truck, placed in service January 31,1950 , weighing 40,000 pounds. He announced that another unit similar to the larger truck will be pur-

4n the absence of a delegate from Hawaii, the Secretary of the Conference presented the report, which had been submitted by mail.

$904381-50-3$ 
chased after July 1, 1950. His division has also purchased a new 100-gallon portable meter-testing unit. The division personnel includes 8 large-capacity scale inspector's and 22 general inspector's.

\section{KANSAS}

\section{Br J. Fred True, State Sealer of Weights and Measures}

Mr. True reported continued progress in Kansas, especially in the vehicle and livestock scale field. A new test truck, carrying 18,000 pounds of test weights, was purchased during the year. This makes two such units for the division.

\section{KENTUCKY}

By Grorge L. Johnson, Director, State Division of Weights and Measures

The Kentucky legislature had adopted a new weights and measures law, which will become effective July 1, 1950. A new vehicle-scale test truck was purchased and placed in service. Office standards and balances, and additional field testing equipment is now being purchased. The city of Lexington has established a new weights and measures division and the city of Louisville has added two inspectors to its staff.

\section{LOUISIANA}

By A. J. MaYer, Director, State Division of Weights and Measures

Mr. Mayer reported much progress during the first full year of operation by the Louisiana division. Three test trucks, carrying 20,$000,2,500$, and 1,500 pounds of test weights, respectively, are in operation.

\section{MAINE}

Br. James A. Borue, Deputy State Seater of Weights and Measures

$\mathrm{Mr}$. Boyle reported the adoption of the Handbook $\mathrm{H} 44$ codes by the State of Maine. He stated that a 100-gallon portable meter-testing unit had been placed in selvice, and that a new vehicle-scale test truck had been purchased, during the year. 'The Department's program of measuring the capacities of fishing boats was also described.

\section{MARYLAND}

Br A. Mon'on Thomas, Director of Inspections and Licenses, Montgomery County

Mr. Thomas reported for Montgomery County only. He pointed out that Montgomery County is immediately adjacent to the District of Columbia, and that its population has increased tremendously within the past few years. 'Two inspector's are now employed by the County.

\section{MASSACHUSETTS}

Br. Jomn P. McBride, State Director of Standards and Necessaries of Life

Mr. McBride reported some progress in Massachusetts regarding legislation for sale by weight of ice cream, but indicated that they 
were not wholly satisfied yet. He also commented upon the difficulties encountered with the marked weights and prices on prepackaged perishable commodities.

\section{MICHIGAN}

Br Milws A. Neuson, Chief, Bureau of Marketing and Enforcement

Mr. Nelson reported that his staff consists of 40 men making both food and weights and measures inspections and 5 men testing largecapacity scales and wholesale measuring devices. In addition to the State staff, some 70 sealer 5 , in 26 cities and 7 counties, are active. He stated that they had purchased and expected early delivery on a 500gallon portable meter-testing unit.

\section{MINNESOTA}

Br Erling Hansen, Supervisor, State Department of Weights and Measures

Mr. Hansen said that effort was being made to replace five vehiclescale test trucks with larger units. He reported the addition of 6 inspectors to the staff, during the year, and said 2 more were expected to be added on July 1, 1950. This will make a total of 35 State inspector's.

\section{MISSISSIPPI}

By Aluan McClune, Chief Inspector, Department of Agriculture ${ }^{5}$

Mr. McCluer reported that the legislature adjourned without passing the general weights and measures bill. A bill directing the Department of Agriculture to test all livestock scales was passed, however. The Department will attempt to purchase a medium-sized test truck and start this program of inspection as soon as practicable.

MISSOURI

By Joserit A. Bernaro, Commissioner of Weights and Measures, City of St. Louis

Mr. Ber'nard reported for the City of St. Louis only. He stated that there had been an increase in the number of inspections and a decrease in the number of complaints, during the year, and noted that there had been a marked decrease in the number of coal users in the city.

\section{NEBRASKA}

BY W. W. GRar, Chief Inspector of II eights and Measures, City of Omaha

Mr. Gray reported only for the City of Omalia, saying that a campaign to educate the public liad been instituted and that it was producing good results in the way of better cooperation with the department. Two inspectors have been added to the staff and additional equipment for testing large-capacity scales and wholesale meters is being sought.

\footnotetext{
5In the absence of a delogate from Mississilpi, the Secretary of the Conference presentrd the report, which had been submitted by mail.
} 


\section{NEVADA}

Bx WAYne B. ADans, State Seater of Weights and Measures ${ }^{6}$

Mr. Adams reported the addition of a new 84-gallon prover, for the testing of vehicle-tank meters at the Reno office. He reported progress in the enforcement of the Anti-Freeze Law passed in 1949, and stated that efforts were being made to secure a larger vehicle-scale test truck during the coming year.

\section{NEW HAMPSHIRE}

\section{Bx Albert H. Dittrich, Commissioner of Weights and Measures}

Mr. Dittrich reported that the Department of Weights and Measures is being merged with the Department of Agriculture. He expressed the belief that this reorganization will be beneficial to the Weights and Measures Department, and that it should help in getting some additional badly needed equipment, especially a large-capacity scale-testing unit.

\section{NEW JERSEY}

By Joseph G. Rogers, Deputy Superintendent, State Division of Weights and Measures

Mr. Roger's reported that there are 128 inspectors in New Jersey, including the State, county, and city departments, that all are under civil service, that recent salary increases have been allowed in many instances, that the State has acquired a new vehicle-scale test truck, and that the legislature has passed a new thread law, although eight other weights and measures bills failed to pass.

NEW YORK

By Chement A. Baker, Director, State Bureau of Weights and Measures

Mr. Baker reported the passage of two weights and measures bills by the New York legislature. One of these amended the law governing the size of milk and cream containers, so as to include containers for sour cream. The other bill requires the sale of charcoal by net weight instead of by dry measure.

\section{NORTH CAROLINA}

\section{Bx C. D. Bauconr, State Superintendent of Weights and Measures}

Mr. Baucom reported that they had been successful in employing a sizable number of engineers and chemists in the Division and that the total personnel stands at 77 people, at this time. He enumerated some of the equipment operated by the division, including a new vehicle-scale test truck weighing approximately 40,000 pounds. A new code for the sale of liquefied petroleum gas was prepared and promulgated during the year.

\footnotetext{
${ }^{6}$ In the absence of a delegate from Nevada, the Secretary of the Conference presented the report, which had been submitted by mail.
} 
NORTH DAKOTA

Bx A. J. Jensen, Chief State Inspector of Weights and Measures

Mr. Jensen related the progress made by the North Dakota department during the past fer years. He reminded the Conference that it had been 18 years since he made his first trip to Washington as the official representative of his State and announced with much regret that he was learing State service and that this would be his last Conference as a State Weights and Measures Official.

OHIO

\section{By V. D. Campbel. Deputy State Seater}

Mr. Campbell presented his superior officer, Mr. C. W. Van Schoik, Chief, Division of Foods and Dairies, Olico Department of Agriculture, to the Conference. He announced that a second vehicle-scale test truck will be placed in service very soon. An increased budget for weights and measures work will be requested at the next session of the legislature. Mr. Campbell also reported progress toward the promulgation of Handbook H44 material in Ohio.

\section{OKLAHOMA}

\section{Bᄃ T. C. BECK, Assistant Director, Marketing Division}

Mr. Beck reported that the present Oklahoma law applies only to agricultural products and to weighing and measuring devices used in the purchase and sale of these products. They have 8 inspectors for small-capacity scales, with two trucks for large-capacity scales. Approximately 75 percent of the small-capacity scales and 60 percent of the large-capacity scales have been found to be incorrect upon the first test.

\section{PENNSYLVANIA}

\section{By Spencer H. Seighman, Assistant Director, State Bureau of Standard Weights and Measures}

Mr. Seighman reported that a survey is being made of present laws, and bills are being prepared for presentation to the 1951 session of the General Assembly, to effectuate desirable amendments. He stated that Handbook H4t material had been officially adopted in Pennsylvania, and that a reprint of their own Handbook is to be made in the near future.

PUERTO RICO

\section{By José R. Rivera, Chief Engineer, Pubtic Service Commission}

$\mathrm{Mr}$. Rivera reported that the Bureau of Weights and Measures in Puerto Rico was created in 1913. The present staff consists of a Chief Inspector, 15 field inspectors, and a chemist. Of the 235,874 devices inspected during the fiscal year 1948-49, 93 percent were new devices. The vast sugar industry consumes much of the time of the Bureau staff. 


\section{SECOND SESSION-AFTERNOON OF TUESDAY, MAY 23,1950}

(The Conference reassembled at 2:15 p. m., J. P. Leonard, Vice President of the Conference, presiding.)

\section{ABSTRACTS OF STATE REPORTS-CONTINUED}

\section{RHODE ISLAND}

\section{Br EDWard R. Fismer, State Sealer of Weights and Measures}

Mr. Fisher reported that the State's new unit for testing wholesaletype and vehicle-tank meters had been placed in service during the year and that it had proved to be a very efficient piece of equipment. He also stated that the State office had sponsored the formation of a State Sealers' Or'ganization.

\section{SOUTH CAROLINA}

\section{Br Chovine R. Sprott, Deputy Commissioner of Agriculture}

Mr. Sprott reported that a new 50-gallon meter prover, for testing meter's on fuel-oil trucks, and a new light scale test truck carrying 2,000 pounds of weights, had been purchased. Plans are being made to erect another permanent vehicle-tank calibrating station. A special survey of retail gasoline pumps has been made and a similar survey concerning the weights of prepackaged perishable commodities will be started soon.

\section{TEXAS}

\section{Bу O. A. KinkLand, State Inspector of Weights and Measures}

Mr. Kirkland reported that four additional inspectors have been provided. Equipment for testing hand-operated grain hopper scales, including a truck, 10,000 pounds of 50 -pound test weights, and a portable balance for testing counterpoise weights, has been purchased and placed in service. One vehicle-scale test truck has been completely renewed, including new body, new hoist, and other equipment.

\section{UTAH}

Br E. C. Westwoon, Sealer of Weights and Measures, City of Salt Lake City

Mr. Westwood reported that the State Department of Utah is not too active, through a lack of sufficient appropriations. Reporting for the City of Salt Lake, he said that they have a five-man department, and that their equipment is reasonably sufficient to take care of their needs. 


\section{VERMONT}

By George E. Carpenter, Supervisor, State Division of Weights and Measures

Mr. Carpenter reported that there are no local sealer's in Vermont. All work is carried on by the State. The persommel of the Division consists of the Supervisor, three inspectors, and a secretary. A vehiclescale test truck and a portable unit for testing vehicle tanks and wholesale meters, are operated.

\section{VIRGINIA}

\section{Br R. D. Tinompson, Supervisor, State Section of Weights and Measures}

Mr. Thompson reported an increase of 28 percent in the number of devices tested and a comparable inclease in supervisory activities, such as package reweighing. One additional State Inspector has been added to the staff. An order has been placed for' a new vehicle-seale test truck, which will carry 12,000 pounds of weights. Handbook H+4 material was officially promulgated. The office and laboratory were moved into modern and adequate quarters.

\section{WASHINGTON}

Br Donald W. Turnaulu, Supervisor, Division of Licenses and Standards, City of Seattle

Mr: Turnbull, reporting for the City of Seattle, stated that a permanent station for the testing of vehicle tanks and meters is now being erected. Approximately 25 percent of the gasoline pumps tested in 1949 were found to be incorrect. The Division tests the meters on some 344 taxicabs each year.

\section{WISCONSIN}

By George W. Warner, Supervisor, State Division of Weights and Measures

Mr: Warner reported that his Division enforces numerous laws other than those pertaining to weights and measures, among which are the false or misleading advertising law. Some of the experiences of the division in these other fields were related by Mr. Warner.

\section{WYOMING}

By Charles H. Oanuex, State Inspector of Weights and Measures

Mr: Oakley reported the purchase of a new vehicle-scale test truck which carries 16,500 ponnds of weights and has a gross weight of about 35,000 pounds. He also stated that an additional truck is being built at this time. Handbook H4t material has been officially promulgated, and the State is erecting a new office building, in which the Division hopes to have adequate office and laboratory space. 
ABSTRACTS OF REPORTS OF REPRESENTATIVES OF STATE AND REGIONAL ASSOCIATIONS OF WEIGHTS AND MEASURES OFFICIALS

CALIFORNIA ASSOCIATION OF WEIGHTS AND MEASURES OFFICIALS

Bx Charles Monris Futuler, Sealer of Weights and Measures of Los Angeles County, California

Mr. Fuller emphasized two features of their Association operations. One was the series of area meetings held. The State is divided into five areas; three meetings are held in each area, in addition to the Annual State Conference, each year. The other feature is the Association Legislative Committee; the five chairmen of the area groups comprise the committee. This gives the Legislative Committee a very close tie-in with all local sealers.

\section{CONNECTICUT SEALERS' ASSOCIATION}

Br Frank M. Greene, Deputy Commissioner, Food and Drug Commission of Connecticut

Mr. Greene said that the Association sponsors two meetings a year, one in the summer and one in the winter. The winter meeting is of 2 days' duration and the summer meeting is a 1-day conference.

\section{ILLINOIS WEIGHTS AND MEASURES ASSOCIATION}

\section{BY JonN J. LevitT, State Superintendent of Standards}

Mr. Levitt stated that the Association held a highly interesting and instructive conference in Chicago in December 1949, which was well attended. He expressed the appreciation of the Association to all of those who took part in the meeting.

\section{INDIANA ASSOCIATION OF INSPECTORS OF WEIGHTS AND MEASURES}

By James A. Hilgemand, Inspector of Weights and Measures of Fort Wayne

Mr: Hilgemann said that the principal activities of the Association are the two meetings held annually, that is, the Annual Conference held each spring and the fall meeting, and the question-and-answer program. Almost 600 questions have been discussed and authoritative answer's developed. 'These questions and answer's are available to weights and measures officers and other interested persons, in printed form.

\section{MASSACHUSETTS WEIGHTS AND MEASURES ASSOCIATION}

By Frank Draginetti, Sealer of Weights and Measures of Agawam

Mr. Draghetti commented upon the value of the Annual Conference of the Association to the local sealer. He said that area meetings were also held, in certain sections of the State, about three times per year. The Annual Conference is held in October. 
MICHIGAN ASSOCIATION OF WEIGHTS AND MEASURES OFFICIALS

Br Janres H. Hitchixas, Inspector of Weights and Measures of Detroit

Mr. Hitchings stated that the Association has an active membership of about 100 weights and measures officials. In addition to the Annual Conference held each year, area meetings are held by the officials in the vicinity of Detroit.

\section{NEW JERSEY WEIGHTS AND MEASURES ASSOCIATION}

Br Wrnfreud K. Tromrpson, Assistant Superintendent of Weights and Measures of Cumberland County

Mr. Thompson announced that two Weights and Measures Luncheon Clubs had been organized by association members, one in the north and the other in the southern part of New Jersey. These clubs meet once a month. The 40th Annual Conference of the Association is to be held in Atlantic City on September 5-8, 1950.

NEW YORK STATE WEIGHTS AND MEASURES ASSOCIATION

By GuY T. Parsons, Sealer of Weights and Measures of Delaware County

Mr. Parsons stated that the Association holds its Annual Conference in the summer. They have two area organizaitons which hold semiannual meetings. One of these is in the eastern part of the State, and the other is in the western part. The 43rd Annual Conference will be held in Watertown on July 18-20, 1950.

NORTHWEST WEIGHTS AND MEASURES ASSOCIATION

BY A. J. JENSEN, Chief Inspector of Weights and Measures of North Dakota

Mr. Jensen spoke of the increase in membership of the Association, and complimented the Mimnesota department upon its efforts in behalf of the organization. The 14th Annual Conference of the Association will be held in St. Paul, Minnesota, on June 26-28, 1950.

OHIO SEALERS' ASSOCIATION

By Leon E. Bates, Deputy Sealer of Weights and Measures of Wood County

Mr. Bates said that two general conferences and three area meetings are held each year. Open-forum discussions are encouraged at all meetings. Since practically all enforcement work is done by local officials in Ohio, he stated that these meetings serve a very worth while purpose in helping to coordinate the work. 
PENNSYLVANIA ASSOCIATION OF INSPECTORS OF WEIGHTS AND MEASURES

By Spencer H. Simamran, Assistant Director, State Bureau of Standard Weights and Measures of Pennsylvania

Mr. Seighman spoke of the increased attendance at the 34th Annual Conference of the Association in 1949, and the excellent results which they have obtained from their School of Instruction. The 35th Annual Conference will be held in Bethlehem.

RHODE ISLAND WEIGHTS AND MEASURES ASSOCIATION

By Edward R. Fismer, Sealer of Weights and Measures of Rhode Istand

Mr. Fisher told of the formation of the Rhode Island Association in November 1949. Neetings have been held to select officers and prepare a constitution. The first conference will be held in Providence sometime in September 1950.

SOUTHERN WEIGHTS AND AND MEASURES ASSOCIATION

BY JoHN I. MoORE, Supervising Inspector of Weights and Measures of North Carolina

Mr. Moore said that the fourth annual conference of the Association was held in Biloxi, Mississippi, on November 3-5, 1950. An inmovation in the meeting was the holding of group discussions, on various subjects, simultaneously, allowing members to attend the discussion in which they were most interested. The Association Committee on Education has started the monthly publication of a News Letter, which is mailed to all members. The 5th Annual Conference of the Association is to be held in Charleston, South Caroline, during the last week in September 1950.

\section{TEXAS WEIGHTS AND MEASURES ASSOCIATION}

Br O. A. Kinkland, State Inspector of Weights and Mensures of Texas

Mr. Kirkland stated that the Texas Association has curtailed its activities, insofar as general amnual conferences are concerned, since the organization of the Southern Association. Texas meetings have been limited to Schools of Instructions for officials. This policy is to continue through 1950.

VIRGINIA WEIGHTS AND MEASURES ASSOCIATION

Br Conwar C. Mundr, Chief, Bureau of Weights and Measures of Richmond

Mr. Mundy said that the Virginia Association is in its sixteenth year and that it has never failed to hold an ammual meeting during this period. The 15th Ammual Conference was held in Roanoke, Va., on October 13 and 14, 1949, and the 16th Annual Conference will be held in Virginia Beach on September 14 and 15, 1950. 
REPORT OF THE NATIONAL CONFERENCE COMMITTEE ON LEGISLATION, PRESENTED BY ROLLIN E. MEEK, CHAIRMAN

Your Committee on Legislation has devoted considerable effort, since the adjournment of the Thirty-Fourth National Conference on Weights and Measures, to two important assignments given it by that Conference. One of these had to do with the drafting of proposed model legislation pertaining to the licensing of weighmaster's, and the other called for a study and recommendations on a proposed model thread law.

Before going into the details of these assignments, it was necessary for the Committee to give careful consideration to the possibility that the Model State Law on Weights and Measures might become too long and too comprehensive for enactment by States with little or no active weights and measures supervision. As a result of this consideration, the Committee, in taking up its first assignment, decided against recommending for incorporation into the Model Law several sections relating to the licensing of reighmaster's. Instead, it was considered more desirable to recommend the adoption of an entirely separate model law to cover this subject. Furthermore, it would seem advisable for a State to enact a general weights and measures law based on the present Model Law and to establish satisfactory enforcement, before enacting weighmaster legislation.

Several reasons can be advanced for the establishment of a satisfactory weights and measures supervision in a State before the enactment of weighmaster legislation such as is being proposed by your Committee. Among these is the authorization given the enforcing official to promulgate such rules and regulations as are deemed necessary to carry out the provisions of the act; passing on the qualifications, by the enforcing official, of the applicant for a license as a licensed public weighmaster; the periodic inspection and testing, by weights and measures officials, of weighing devices used by weighmasters; and a thorough knowledge of weighing devices and weighing. practices on the part of the enforcing official and his deputies to equip them to adequately supervise enforcement of the act.

Your Conmittee gave a summary of a rather brief study of existing State weighmaster legislation in its report to the last Conference. At that time the Committee was not prepared to submit a proposed model law. As a result of this study, the Committee is now in a position to offer a proposal which, if accepted by the Conference and enacted into law by the various States, should tend to promote more accurate quantity determinations and bring about a high degree of uniformity in a field closely associated with weights and measures supervision.

While the Committee believes its proposal is a satisfactory one and in keeping with information at hand, nevertheless, it is recommending tentative adoption, with final action to be taken during the next meeting of the National Conference on Weights and Measures. Since what the Committee is proposing is something entirely new and something that probably has not been given sufficient consideration by the Conference, the delay in taking final action would appear to be in accoldance with established precedent. 
Further study of the proposal in the meantine would seem advisable-particularly so if constructive criticisms are received from member's of the Conference or other interested parties.

The text of the proposed model weighmaster law is as follows:

\section{A BILL}

FOR AN ACT concerning weighmasters, providing for the licensing thereof, defining their powers and duties, and prescribing penalties.

SEc. 1. When used in this act unless the context requires otherwise:

(a) The words "licensed public weighmaster" shall mean and refer to a natural person licensed under the provisions of this Act.

(b) The word "vehicle" shall mean any device in, upon, or by which any property, produce, commodity, or article is or may be transported or drawn.

(c) The word "superintendent (commissioner)" shall mean and refer to the State superintendent (commissioner) of weights and measures.

SEC. 2. The superintendent (commissioner) is authorized to enforce the provisions of this Act and to promulgate, in the manner provided by law, such rules and regulations as are deened necessary to carry ont the provisions of this Act.

SEC. 3. A citizen of the United States or a person who has declared his intention of becoming such a citizen, who is a resident of the State of

not less than 21 years of age, of good moral character, and who has the ability to weigh accurately and to make correct weight certificates, and who has received from the superintendent (commissioner) a license as a licensed public weighmaster shall be styled and authorized to act as a licensed public weighmastel.

SEc. 4. Application for a license as a licensed public weighmaster shall be made upon a form provided by the superintendent (commissioner) and the application shall furnish evidence that the applicant has the qualifications required by Section 3 of this Act.

SEC. 5. The superintendent (commissioner) may adopt rules for determining the qualifications of the applicant for a license as a licensed public weighmaster. He may pass upon the qualifications of the applicant upon the basis of the information supplied in the application, or he may examine such applicant orally or in writing or both for the purpose of determining his qualifications. He shall grant licenses as licensed public weighmasters to such applicants as may be found to possess the qualifications required by Section 3 of this Act. The superintendent (commissioner) shall keep a record of all such applications and of all licenses issued thereon.

SEC. 6. Before the issuance of any license as a licensed public weighmaster, or any renewal thereof, the applicant shall pay to the superintendent (commissioner) a fee of \$5.00. Such fees shall be deposited with the State Treasurer to be credited to a fund to be used by the superintendent (commissioner) for the administration of this Act.

SEc. 7. The superintendent (commissioner) may, upon request and without charge, issue a limited license as a licensed public weighmaster to any qualified officer or employee of a city or county of this State or of a State commission, board, institution, or agency, authorizing such officer or employee to act as a licensed public weighmaster only within the scope of his official employment in the case of an officer or employee of a city or county or only for and on behalf of the State commission, board, institution, or agency in the case of an officer or employee thereof.

SEc. S. Each license as licensed public weighmaster shall be issued to expire on the thirty-first day of December of the calendar year for which it is issued: Provided, That any such license shall be valid through the thirty-first day of January of the next ensuing calendar year or until issuance of the renewal license, whichever event first occurs, if the holder thereof shall have filed a reneral application with the superintendent (commissioner) on or before the fifteenth day of December of the year for which the current license was issued: And provided further, That anv license issued on or after the effective date of this Act and on or before the thirty-first day of December 19 , shall be issued to expire on the thirty-first day of December of the next ensuing calendar year. Renewal applications shall be in such form as the superintendent (commissioner) shall prescribe.

SEC. 9. Each licensed public weighmaster shall, before entering upon his duties, make oath to execute faithfully his duties. The issuance of a license 
as licensed public weighmaster shall not obligate the State to pay to the licensee any compensation for his services as a licensed public weighmaster. Wach licensed public weighmaster shall, at his own expense, provide himself with an impression seal. His name and the word(s) (insert name of State) shall be inscribed around the outer margin of the seal and the words "licensed public weightmaster" shall appear in the center thereof. The seal shall be impressed upon each weight certifieate issued by a licensed public weighmaster.

SEc. 10. The superintendent (commissioner) shall prescribe the form of weight certificate to be used by a licensed public weighmaster. The weight certificate shall state the date of issuance, the kind of property, producc, commodity, or article weighed, the name of the declared owner or agent of the owner and/or of the consignee of the material weighed, the accurate weight of the material weighed, the means by which the material was being transported at the time it was weighed, and such other available information as may be necessary to distinguish or identify the property, produce, commodity, or article from other's of like kind. Such weight certificate when so made and properly signed and sealed, shall be prima facie evidence of the accuracy of the weights shown.

SEc. 11. A licensed public weighmaster shall not enter on a weight certificate issued by him any weight values but such as he has personally determined, and he shall make no entries on a weight certificate issued by some other person. A weight certificate shall be so prepared as to show clearly what weight or weights were actually determined. If the certificate form provides for the entry of gross, tale, and net weights, in any case in which only the gross, the tare, or the net weight is detelmined by the weighmaster he shall strike through or otherwise cancel the printed entries for the weights not determined or computed. If gross and tare weights are shown on a weight certificate and both of these were not determined on the same scale and on the day for which the certificate is dated, the weighmaster shall identify on the certificate the scale used for determining each such weight and the date of each such determination.

Sec. 12. When making a weight determination as provided for by this Act a licensed public weighmaster shall use a weighing device which is of a type suitable for the weighing of the amount and kind of material to be weighed, and which has been tested and approved for use by a weights and measures officer of this State within a period of 12 months immediately preceding the date of the weighing.

SEc. 13. A licensed public weighmaster shall not use any scale to weigh a load the value of which exceeds the nominal or rated capacity of the scale. When the gross or tare weight of any rehicle or combination of vehicles is to be determined, the weighing shall be performed upon a scale having a platform of sufficient size to accommodate such vehicle or combination of vehicles fully, completely, and as one entire unit. If a combination of velicles must be broken up into separate units in order to be weighed as prescribed herein, each such separate unit shall be entirely discomnected befole weighing and a separate weight certificate shall be issued for each such separate unit.

SEc. 14. A licensed public weighmaster shall keep and preserve for at least one year, or for such longer period as may be specified in the regulations authorized to be issued fol the enforcement of this Act, a legible carbon copy of each weight certificate issued by him, which copies shall be open at all reasonable times for inspection by any weights and measures officer of this State.

SEc. 15. Whenever in any other State which licenses public weighmasters, there is statutory authority for the recognition and acceptance of the weight certificates issued by licensed weighmaster's of this State, the superintendent (commissioner) of this State is authorized to recognize and accept the weight certificates of such other State.

SEc. 16. The following pelsons shall not be required but shall be permitted to obtain licenses as licensed public weighmasters: (1) a weights and measures officer when acting within the scope of his ofincial duties, (2) a person weighing property, produce, commodities, or articles which he or his employer, if any, is either buying or selling, and (3) a person weighing property, produce, commodities, or articles in conformity with the requilements of Federal statutes or the statutes of this State relative to warehousemen or processors.

SEc. 17. No person shall assume the title "licensed public weighmaster," or any title of similar import, perform the duties or acts to be performed by a licensed public weighmaster under this Act, hold himself out as a licensed public weighmaster, issue any weight certificate, ticket, memorandum, or 
statement for which a fee is charged, or cugage in the full-time or part-time lusiness of public weighing, unless lie lolds a valid license as a licensed public weiglmaster. "Pulbic weighing," as used in this section, shall mean the weighing for any person, npon request, of property, produce, commodities, or articles other than those which the weigher or his employer, if any, is either buying or selling.

siec. 18. The supcriutcudent (commissioner) is anthorized to suspend or revoke the license of any licensed public weighmaster (1) when he is satisfied, aftcr a hearing yon 10 days' notice to the licensee, that the said licensee has violated any provision of this Act or of any valich regulation of the superintendent (commissioner) affecting licensed public weighmasters, or (2) when a licensed public weighmaster has been convicter in any court of competent jurisdiction of violating any provision of this Act or of any regulation issued under authority of this Aet.

SEc. 19. Any person who requests a licensed public weighmaster to weigh any property, produce, commodity, or article falsely or incorlectly, or who requests a false or incorrect weight certificate, or any pcrson who issues a weight certificate simulating the weight certificate prescribed in this Act and who is not a licensed public weighmaster, shall be guilty of a misclemeanor and upon conviction for the first offense shall be punished by a fine in any sum not less than twenty-five dollars or more than one hundrerl dollars: and upon a second or subsequent conviction such person shall be punished by a fine in any sum not less than one hundred dollar's or more than five hundred dollars or by imprisomment for not less than thirty days or mole than ninety days or by both such fine and imprisomment.

SEc. 20. Any licensed public weighmaster who falsifies a weight certificate, or who delegates his authority to any person not licensed as a licensed public weighmaster, or who preseals a weight certificate with his official seal before performing the act of weighing, sluall be guilty of a misdemeanor and typon conviction shall be punished by a fine in any sum not less than fifty dollars or more than five hundred dollars or by imprisomment for not less than thirty days or more than ninety days or by both such fine and imprisonment.

SEc. 21. Any person who violates any provision of this Act or any rule or regulation promulgated pursuant thereto for which no specific penalty has been provided shall be guilty of a misdemeanor and upon conviction shall be punished by a fine in any amount not less than twenty-five dollars or more than one hunired dollars.

SEc. 22. All laws and parts of laws in conflict herewith are hereby repealed.

SEC. 23. If any provision of this Act is declared uneonstitutional, or the applicability thereof to any person or circumstance is held invalid, the constitutionality of the remainder of the Act and the applicability thereof to other versons and circumstances shall not be affected thereby.

Mr. Мeer. Since the Committee's Report covers two entirely unrelated subjects, I believe it will be in order that we take action at this time on the first proposal which has to do with model weighmaster legislation. Therefore, Mr. Chairman, in order to bring this matter before the Conference, I move the adoption of that portion of the report which has already been presented. to.)

(The motion was seconded, the question was taken, and the motion was agreed

\section{Mr. Meer (reading) :}

Before submitting a proposed revised textile section of the Model State Law on Weights and Measures for the consideration of this Conference, your Committee would like to call attention to the actions heretofore taken in the matter of model textile legislation by the National Conference on Weights and Measures. For many years there has been included in the Model Law a section on textile materials. Its citation is Section 19 of Form 1, Section 26 of Form 2, and Section 24 of Form 3. From time to time amendments to the Model Law have been adopted, as these became desirable to meet changing conditions: however, the textile section has remained unaltered for many years. 
Attention was focused on thread a few years ago by the Conference Committee on Nethods of Sale of Commodities, and this Committee, working with representatives of the Thread Institute, Inc., made some very excellent recommendations to the Thirty-Fourth National Conference on Weights and Measures, which were adopted by an unanimous rote. Immediately following this action, a proposed revision of the textile section of the Model Law to make separate provision for marking thread was offered the Conference by The Thread Institute, Inc. This proposal was then referred to the Legislative Committee of the Conference for study and recommendations to be presented at this time.

Your Committee quickly recognized the desirability of incorporating any new requirements on thread into the existing textile section of the Model Law, to produce a single section dealing with textile materials. As was pointed out earlier in this report, it was considered extremely important to keep the length of any suggested legislation at the practicable minimum, as experience has demonstrated that the longer a bill the more difficult it may be to bring a bout its enactment. Accordingly, the first effort was to put together existing provisions of the textile section of the Model Law and the new proposals, in such a way that all desired requirements might be included with the greatest brevity consistent with clarity.

While your Committee did not lose sight of the fact that the proposed model thread law prepared by the Thread Institute, Inc., was referred to it for study and recommendations, it took into consideration the authority which has been given the Committee to present to the National Conference on IVeights and Measures, at any time, suggestions it deems advisable in the field of weights and measures legislation. Since it is the best judgment of the Committee that a revised section covering all textile materials should be recommended for incorporation into the Model Law, this report, containing such a recommendation, is not believed to be inconsistent with the authorization heretofore given.

From the begimning of discussions on a revised textile section, your Committee has recognized the importance of excluding from the revision those purely technical and administrative provisions which should properly be covered by regulations issued under statutory authority by enforcing officials. It was firmly believed that the revised section, like the pattern set throughout the Model Law, should state general principles and broad requirements, but that technical details and enforcement procedures should be established in regulations, within the scope of the statute.

The recommendations contained in the report of the Conference Committee on Methods of Sale of Commodities, to a very large extent, have been incorporated into the new textile section to be offered by your Committee. Notable among these are proper identification of the product as to the name and place of business of the manufacturer. packer, or distributor, and the mandatory requirement that thread sold in units, the net weight of which is less than two aroirdupois ounces, shall be sold by linear measure.

The recommendation of the Committee on Methods of Sale of Commodities relating to specific tolerances was not included in your Committee's proposal, but the enforcing official is mandated to include reasonable tolerances in regulations to be adopted for the enforce- 
ment of the provisions of the section. It is to be presumed that State enforcement officials will be guided by recommendations of the $\mathrm{Na}$ tional Conference in the adoption of regulations which include the establishment of reasonable tolerances. At this point, it might be well to stress the fact that this Conference is on record as recommending a tolerance of three percent on threads, based on a test of an average of not less than 10 units of the same type and put-up, to be selected at random.

It has been pointed out that weights and measures statutes have been invalidated by the courts because specific tolerances included in the laws were leed to be improper. When this happens, the entire legulatory program based on such a statute is destroyed, and camnot be resumed until new legislation is enacted. On the contrary, if tolerances are merely authorized, to be promulgated by the enforcing official, and if the tolerances so promulgated are subsequently and successfully attacked, the basic statutory provisions remain in effect. It is then only necessary for the enforcing oflicial to promulgate new tolerances conforming to the mandate of the court, for the program to continue without serious interruption.

Your Committee does not agree with the argument occasionally advanced to the effect that the inclusion of tolerances in the Model Law would be in the interest of greater uniformity. Neither is it in agreement with those who argue, with respect to the inclusion of tolerances in the Model Law, that their problems are unique as compared to others. It should be remembered that legislative bodies have little time to study technical phases of legislation and that some highly desirable feature may be changed in committee or on the floor to meet the whim of someone not qualified to influence such a decision. It would seem much more logical for trained enforcement officials, acting on the experience and best judgment of the National Conference on Weights and Measures, to adopt and promulgate such technical requirements.

A reduction of the recognized tolerance on thread from five percent to three percent as brought about by the last Conference, largely througli the efforts of the Committee on Methods of Sale of Commodities, serves as a testimonial to the argument that specific tolerances should never be set out in weights and measures legislation. With a definite trend toward refinement in the mechanics of reighing and measuring, this Conference should hold steadfast to the position it has taken of insisting on a reduction of tolerances wherever practicable. While no further reduction in thread tolerances is known to be contemplated, nevertheless, the desirability of leaving such matters to enforcement officials, benefiting from experience and the advice of technical experts, is clearly evident.

In your Committee's effort to draft an acceptable revision of the textile section of the Model Law on Weights and Measures, a vote of thanks is due the thread industry for the splendid cooperation received. The Committees on Legislation of both The Thread Institute, Inc., and the National Conference on Weights and Measures began work on the proposed section shortly after adjournment of the ThirtyFourth National Conference. While there were several differences of opinion at the beginning, each group made a number of concessions before the proposal to be presented was agreed upon at a joint meeting 
of the Committee and representatives of The Thread Institute, Inc., held in Providence, Rhode Island, on September 6, 1949. However, in all fairness to the Thread Institute, Inc., it should be mentioned that this organization has reviewed its position and now appears to favor the adoption, by the Conference, of (1) a section in the Model State Law on Weights and Measures covering thread marking with the inclusion of specific tolerances, or (2) a revision of the present textile section including such tolerances.

Since the proposal being submitted calls for a revision of the present Model Law and the subject matter has been given careful consideration during previous Conferences, your Committee recommends final adoption at this time. The following is the text of the recommended revised section of the Model $\mathrm{Law}$ pertaining to textiles:

\section{TEXTILE SECTION}

\section{MODEL STATE LAW ON IVEIGHTS AND MEASURES}

It shall be unlawful to keep for the purpose of sale, offer or expose for sale, or sell any textile yard goods put up or packaged in advance of sale in a bolt $01^{\circ}$ roll, or any other textile product put up or packaged in advance of sale in any other unit, for either wholesale or retail sale, unless such bolt or roll, or such other unit, be definitely, plainly, and conspicuously marked to show its net measure in terms of yards or its net weight in terms of avoirdupois pounds and/or ounces, subject, howevel, to the following limitations and requirements :

Any unit of twine or cordage may be marked to show its net measure in terms of feet. Ready-wound bobbins which are not sold separately shall not be required to be individually marked, but the package containing such bobbins shall be marked to show the number of bobbins contained therein and the net weight or measure of the thread on each bobbin. Any unit of sewing, basting, mending, darning, crocheting, tatting, hand-knitting, or embroidery thlead or yarn except nylon hand-knitting yarn, which is not composed in whole or in part of wool, the net weight of which is less than two ounces avoirdupois, shall be marked to show its net measure in terms of yards as unwound from the ball or from the spool or other holder. Any retail unit of a textile product, sold only for household use, consisting of a package containing two $\mathrm{Ol}^{2}$ mole similar individual units, which are not sold separately, shall be marked to show the numbel' of individual units in the package and the net weight or net measure of the product in each individual unit, but this proviso shall not apply where the individual units are separately marked. Any unit of yarn, composed in whole or in part of wool, sold to consumers for handiwork shall be marked to show the net weight of such yarn except that any such unit of tapestry, mending, or embroidery yarn, the net measure of which does not exceed fifty yards, may be marked to show its linear measure only.

The marking required by this section shall in all cases be in combination with the name and place of business of the manufacturer, packer, or distributor of the product, or a trade-mark, symbol, brand, or other mark which positively identifies such manufacturer, packer, or distributor.

Reasonable tolerances shall be permitted, and these shall be inchuded in regulations for the enforcement of the provisions of this section which shall be issued by the State Superintendent (Commissioner.).

The provisions of this section shall not apply to the following textile products when sold at wholesale in bulk by net weight:Cordage, agricultural bag sewing threads, twines, yarns which are to be processed, and yarns which are to be industrially converted into end use products.

R. E. MEEK, Chairman,

C. A. BAKER,

J. A. BERNARD,

J. R. Воотн,

F. C. YARBRougt,

Committee on Legislation. 
Mr. Mrex. Mr. Chairman, I move the adoption of that portion of the Committee's report which pertains to textile legislation.

(The motion was seconded.)

Mr. Batcosr. Do you provide for the labeling of the bobbin upon which the thread is wound? Some time ago we had occasion to investigate short measure of thread, and there was no way of identifying the party responsible for winding the thread upon the spool or bobbin.

Mr. MEeк. The section provides that, "The marking required by this section shall in all cases be in combination with the name and place of business of the manufacturer, packer, or distributor of the product, or a trade-mark, symbol, brand, or other mark which positively identifies such manufacturer, packer, or distributor." I should like to call on $\mathrm{Mr}$. John Bell, Chairman of the Legislation Committee of the Thread Institute, Inc., to tell us what is the general practice in the industry.

Mr. Belu (Thread Institute, Inc.). The point raised by Mr. Baucom is important, because up to this time there has not been any requirement for a mark of identification to be placed on a spool of thread. Since last year Massachusetts and New Jersey have enacted thread laws embodying, I should say, 95 percent of the wording of this pro. posed bill, and I feel confident that within the next year at least two other States will pass similar legislation.

(There being no further discussion, the question was taken and the motion was agreed to. Thus the Report of the Committee on Legislation was adopted l.y the Conference without amendment.)

\section{A REPORT FROM THE NATIONAL SCALE MEN'S ASSOCIATION}

\section{By J. H. Downir, Secretary. National Scate Men's Association}

It has become a custom to invite the Secretary of the National Scale Men's Association to make a report to you gentlemen here assembled, and as far as I can see, being the Secretary is the only qualification for my being present and speaking to you.

There are now three organizations which are closely allied in weights and measures work: Your National and State Bureaus of Standards, the National Association of Scale Manufacturers, and the National Scale Men's Association. 'The inembers of the National Association of Scale Manufacturers build the scales, the Bureaus of Standards establish performance and specifications, and the National Scale Men's Association make the product of the first meet the demands of the second.

It has been one of the aims of the National Scale Men's Association to further general education with reference to scale maintenance, practice, et cetera. Since the earliest stages of scale usage, there has been a lack of material and too great a secrecy with reference to the craft. Until very recently scale men have guarded very jealously the knowledge they gained in their practice throughout the year's. It has only been within the last decade, when the need for better scale service and more adequate performance was a demand, that cooperation and the exchange of information became common practice. Eren now, sources of information are not. what they should be. There is as yet no class at any of our schools that deals with the subject of scales and weights 
and measures. There is no textbook on the subject. What literature is available is written either in too generalized a form or is generally incompreliensive to the layman.

Today the scale industry embraces innumerable industries and becomes more diversified with each passing day. Interdepartmental records, inventory controls, cost accounting, wage scales, and innumerable bookkeeping practices, as well as the age-old buying and selling by weight, are determined and based on information secured from scales. In some phase of every industry on the face of this earth, weights and measures directly affects every product and every individual. In some way, shape, or form, everything from clothing, food, equipment, and housing is directly related to weights and measures, and yet no one craft has less general information relative to it. As industry progresses, the need for better and faster weighing equipment becomes paramount. Scale manufacturers realize this and are constantly striving to improve the equipment and better maintain that equipment. As these improvements become actualities, it is necrssary that the personnel in the scale industry be acquainted with them in order to properly service and maintain them. 'This information, as developed, should become common information and should be accessible to you, who are in that phase of the craft. We know of no better outlet than through the National Scale Men's Association. But only through the cooperation of the manufacturers, the Bureaus of Standards, and various weights and measures departments throughout the country, and the service personmel in the industry, will it become possible for us to make this modern equipment perform to the requirements of the various functionaries.

The National Scale Men's Association has what we feel is a very well selected educational committee, and it is their intention to compile information in a very complete form so that anyone interested in any phase of scale work will have available text-book material, practical information, and theoretical information of "Scaleology". In the past, glossaries of scale telms have been published, and some paper's read before various meetings, formulas have been shown for various lever ratios, and scaling practices have been explained, but it has been in an ancient form, that is, by word of mouth-nothing in general library reference work and made available to any and all.

We hope through our Committee on Education to have the cooperation of all three previously mentioned associations-and to be able to assist in 10 small way in ariving at a standardization of specifications and laws, cocies and construction, performance and practices.

With the establishment of standards, there must, too, be standards of craftsmanship in all groups. It is not sufficient that aptitude of tool usage be enough recommendations for an individual to proclaim himself qualified to service and repair scale equipment. There have never been enough competent scale men available. Education can and will eradicate this shortage and each of us will profit by it.

So again-we must ask for the cooperation of all groups for better education-and we shall-beyond all question and doubt-benefit and prosper-both individually and collectively.

The Crampax. At this point I will recognize the Secretary, to make an announcement. 
The Secretary. I wish to report the receipt of a telegram from Mr. R. O. Russell, Chief of the State Division of Weights and Measures of Alabama, reading as follows:

National Bureau of Standards Handbook H44 adopted by citation by State Board of Agriculture and Industry.

Also, Mr. Meek, Chairman of the Conference Committee on Nominations, wishes me to announce an open session of his Committee at 5 p. m. tomorrow, at which time the Committee will entertain suggestions from the membership of the Conference with respect to nominations for office in this organization.

\section{DUTIES OF AN INSPECTOR IN A SERVICE STATION}

\section{Br W. B. Heascre, Supervising Inspector of Weights and Measures,} City of Detroit, Mich.

When I was asked by the Secretary of this Conference, Mr. Ralph Smith, to prepare a paper on "Duties of an Inspector in a Service Station," I was pleased that he selected a representative from Detroit to prepare it, and I was particularly pleased that he chose this important subject for me to discuss.

The function of a service station is to sell gasoline, oil, grease, alcohol, accessories, and service to owners of all makes of automobiles from all parts of the country; therefore, the duties of an inspector in Detroit should not differ from the duties of an inspector in Maine, Texas, or California.

Our duties in a service station are to inspect and test all liquid measuring devices used in the measuring of gasoline, oil, and grease, all liquid capacity measures and lubricating-oil bottles used for measuring oil and alcohol, to advise the owner on what type of equipment is best suited for his particular needs, to instruct the operators on the proper methods of using and maintaining the equipment, and to see that a purchaser of any commodity, sold by measure in the service station, receives the amount he is paying for.

It is not necessary for an inspector to know all the intricacies of a modern gasoline pump, such as the pumping unit, the pressure relief valve, the by-pass valves, the air eliminator, or the meter itself, but I believe that an understanding of some of the fundamental principles of their operation is essential if intelligent tests are to be applied. This information is not too difficult to obtain. The Bureau of Standards publications carl'y much essential information, the Scale Journal is very helpful and literature published by the pump manufacturers is a very good source. I have been privileged, on occasions, to work with meter engineers and servicemen from the oil companies, in the testing of liquid-measuring devices. The information gained through this contact is invaluable. The engineer's test is usually under ideal conditions, a so-called "laboratory test," the result being what a pump should do when all the component parts are co-ordinated and are working perfectly. The servicemen's test tells you what the pump actually does when it is placed in service. This is the type of test that we are interested in.

When an inspector enters a modern service station, the gasoline pumps should receive his first attention, not because they are any more 
important to us than the other measuring equipment, but their inspection and test is more time-consuming and it is well to get that portion of our inspection completed first. Modern computing pumps are all alike in principle. The design and construction varies with the different makes, but for our purpose the fundamental principles are identical.

Before the pump is given the test for accuracy, it should be given a preliminary inspection for possible violations of the $\mathrm{H} 44$ Code of Specifications. Listed below are some of the more important items of inspections, each in itself very essential to the correct operation of the pump.

1. The pump must be in level position and fastened securely on its platform.

2. There must be no leaks in the nozzle, hose, visigauge, or meter. This can readily be detected by the presence of air in the visigauge.

3. All numerals and indicating graduations must be clean and legible.

4. The indicators must line up with the zero graduations and must be of such a design that an accurate reading is given.

5 . The indicating elements must be at least 36 inches above the floor or driveway.

6. The indicating elements must be returnable to a positive stop at zero, and during this forward motion the shutters must keep all numerals covered.

7. The rate of flow, as recommended by the manufacturer, must appear on the dial.

8. The price per gallon must be prominently displayed on the dial of a computing pump.

9. The value of the smallest graduation on the money-value chart must be one cent up to 30 cents per gallon.

10. A thorough inspection of the pump should be made for any attachment which might be conducive to inaccurate measure or to the perpetration of fraud.

It will require little time for the experienced inspector to make the above inspections. He will quickly acquire the habit of checking these points automatically, but the new inspector should carry a list of the specifications and check them one by one to insure that nothing is forgotten.

It is to be expected that different inspectors will have diverse ideas on how a modern gasoline pump should be tested for accuracy. It is my opinion that the following procedure will tell an inspector all lie is required to know in order for him to approve or condemn a pump on an accuracy test in a periodic inspection of a service station.

1. One draw of 1 gallon at normal speed.

2. Two draws of 5 gallons at normal speed.

3. One draw of 5 gallons at slow speed.

The purpose of the 1-gallon draw is to determine the amount of er'ror resulting from the pump standing idle for a period of time. A 5-gallon draw will tell you the same thing, but I choose a 1-gallon draw to save time. The result of this test determines whether or not the pump is to be given an elapsed-time test, which I will discuss later.

The first 5-gallon draw at normal speed tells you the amount the pump is actually delivering with the whole system primed. The second 5-gallon draw at the same speed is to determine if the pump is repeating its performance. If an error exists in these tests, it could be from one or more of several causes, sucli as a faulty air eliminator allowing the air to be measured by the meter, a worn cylinder wall from the presence of grit or tank scale, hardened leathers caused by 
the presence of water in the system, or the meter might be just out of adjustment.

At this point is the easiest spot on the dial to check the computing mechanism. The Unit-Price Indication on the dial is usually in tenth-cents, such as "28 7/10 cents per gallon." With ten gallons already showing on the dial, the money value should be $\$ 2.87$. If a different amount appears, the pump is not computing at the rate of $28 \frac{7}{1 \pi}$ cents per gallon.

The last 5 -gallon draw, at slow speed, is a special test to determine how much slippage of gasoline through the meter is taking place without actually being measured. The speed recommended for this test is 5 gallons per minute unless it is stated on the dial that accuracy is maintained at any speed. If this is the case, the pump could be tested at a slower rate. The tolerance is no greater for this test than it is at nor'mal speed.

It is now time to check the anti-drain valve. This is a springloaded valve installed in or just ahead of the nozzle. Its function is to hold all the liquid in the hose when the pressure has been shut off. If a pump had no anti-drain valve, the operator conld drain the hose when the pump was idle by simply opening the hand nozzle valve, with the result that the next customer would receive short measure, equivalent to the amount removed from the hose. To test this feature requires very little time. When the pressure is shut off, simply open the hand-nozzle valve and sce if the liquid will run out. If any liquid comes out, the pump should be condemned. I mention that this test should be made at this time rather than before the accuracy test is begun because if the anti-drain is defective, some of the liquid would drain out of the hose and the accuracy of your first 1-gallon draw would be affected.

It is not necessary to give all pumps an elapsed-time test. If the pump is within tolerance on the first draw and the visigauge is free of air, a time test may be forgotten. When air is present in the visigauge a time test is usually necessary, or when the first draw is short and the second draw is within tolerance, a time test should be given. This error may be due to several causes, but usually it is a leak, either in the hose-nozzle valve, the pressure relief valve, the visigauge gasket, the needle valve. or it could be caused by a rapid change of temperature. To make this test, the inspector must diaw a definite anount of gasoline (usually 5 gallons) through the pump and note the reading on his test measure. The pump is then locked and put out of service for a certain period of time (usually one or two hours). The pump is then made to register the same amount as the first test indicated, and the reading on the test measure is again noted. The difference in these two readings is the error in the time test. The tolerance to be allowed is 2 cubic inches per hour.

The pumps have passed the preliminary inspection and are within the tolerances on the accuracy test, so our approval sticker is placed on the dial inside the pump housing. This seal carries the name of the bureau, also a message to the public that this device was tested and found legally accurate for commercial use on May 23, 1950, or whatever the date of test may be.

Should any of the pumps fail to pass the preliminary inspection, or fail to come within the tolerances, as set forth in the $\dot{H} 44$ Handbook, 
the derice should be condemned for repair. A condemnation tag carrying all the reasons why the pump was condemned is placed in a conspicuous spot on the pump with a lead and wire seal.

If the inaccuracy of the pump would seriously affect a delivery to a customer, service from this pump wonld be discontinued until such time as the proper repairs were made; however, if the needed repairs were minor and it would be a hardship on the owner of the station to have the pump out of service, we would allow him to use the pump, providing he would have the necessary repairs made in a reasonable length of time.

It has been suggested that the inspector should adjust the meter when the test shows it to be a little out of tolerance, in order to save himself a trip back for a second test. I would strongly advise against this procedure. An adjustment may correct the error temporarily, but I do not believe that the a verage inspector is required to have, or has, sufficient knowledge of the inner' worlkings of the pump to diagnose the trouble correctly, when experienced servicemen often make several trips before the real trouble is corrected.

There has been much discussion over the year on the advisability of sealing the adjustment on a gasoline pump when the test shows the pump to be correct. 'There are good arguments for and against this procedure. In our territory we have not found it necessary to seal these adjustments. If, by this procedure, the public would be guaranteed full measure, it would be made a requirement, but there are other featnres on a modern pump that may be manipulated by an operator with fraudulent intent, which could be conducive to a greater short measure than the mechanical adjustment. Pump accuracy is not always maintained by operator's having the best of intentions. Conditions do arise which affect the accuracy of the pump whether it is sealed or unsealed, so for these reasons, we feel that nothing is gained by sealing the adjustment.

When complaints of short measure against a service station operator are received, we immediately recheck his equipment. If his equipment is correct, we check the operator for incor'rect use of correct apparatus. This is done by making a purchase in the same fashion as a regular customer would buy gasoline. Our car is equipped with a special auxiliary tank which is always empty when the delivery is begun. After the delivery is completed the tank is drained through a special valve, and measured in our test measures. If short measure occurs, the case is handled in the same way as any other violation in volving weight or measure.

Grease-measuring devices are inspected and tested much in the same manner as the gasoline pumps; however, with the absence of the computing feature, the preliminary inspection will require ver'y little time. Listed below are some of the more important items of inspection as required by the H44 Code.

1. The value of the graduations on the clial must be one pint, a multiple of a pint, or a binar'y submultiple of a pint.

2. The indicator may not be moved forward manually.

3. There must be a positive stop at zero.

4. Means shall be provided for making the device inoperable when the exhaustion of supply of the liquid takes place.

5. A thorough inspection of the device should be made for any attachment which might be conducive to inaccurate measure or to the perpetration of fraud. 
An accuracy test is given by the use of a one pint and a two quart test measure. To test the exhaustion of a supply feature, the liquid in the supply tank must be reduced to a level, a few inches above the bottom of the supply tank. The device is then put into operation until the float is no longer in the liquid. If the indicator stops at this point, this feature is performing its function.

'The device has passed the preliminary inspection and is within tolerance on the accuracy test so the device may be approved.

Liquid capacity measures and lubricating-oil bottles receive our next attention. Many methods of test and inspection of these measures are used in different jurisdictions, but we in Detroit believe that we have the best method of any that has been brought to our attention. 'This method might well be considered by new weights and measures departments.

Our law requires that all measures shall be tested and sealed by our bureau before being used commercially. It is impractical for the field inspector to carry with him the delicate equipment necessary to test liquid measures, and conditions in a service station are such that a good test camnot be given, so for these reasons, the proper place to test liquid measures is in our own laboratory.

Ninety percent of all new measures sold in Detroit are brought to our office for test, by the wholesale houses, before they are sold to the service stations. When the wholesaler receives a shipment, he immediately sends the whole shipment to us for test. This is not a requirement, but, by doing this, he saves the purchasers of the measures many trips to our office to have them sealed. and soon realizes that he is selling more measures by having them sealed before sale to the service station. Our interest in this system is, however, that if for some reason the measures are not approved, the whole shipment is immediately sent back to the manufacturer, or disposed of for other than commercial use.

In our test and inspection of liquid measures, we adhere strictly to the H44 Specifications and Tolerances. They must be of sufficient strength so they will not become indented through ordinary use; they must be one of the legal capacities; the capacity marking must be correct and legible; the capacity must be within the tolerance; and if all the other specifications are complied with, we seal the measure with a power press with the letter "D" for Detroit and the last two figures of the year, such as " 50 " for the year 1950. This seal is always put on in the same place, on the same type of measure, for easier identification, and it is good for the life of the measure. Oil bottles are inspected and sealed much in the same manner, except that an electric etcher, with a diamond point, is used.

When an inspector starts his inspection of liquid measures and oil bottles in the service station, much of the work has already been done. Any that are found to be unsealed are cleaned by the operator and taken to our laboratory for test. If all are sealed, the oil bottles are inspected for proper fill and the liquid measures are inspected for indentations. No other inspection is necessary except that illegal sizes, such as the 5 and 6 quart measures, are immediately removed from service.

A complete record is made of all the equipment tested and the result of each test. Reasons are given why a device is condemned. The time 
limit allowed for repairs and the operator's name who received our instructions are noted. A duplicate copy of this report is made and through the filing system in our office we are notified when the reinspection is due, which is usually between 7 and 10 days. This duplicate copy is then taken back to the service station to see if all the corrections have been made.

Our duties in a service station should not end with the approval of all the measuring equipment. Too often the station operator has never been instructed on what is required of him under the local laws. His source of information is limited on how best to operate and maintain the equipment. Much valuable information is gained by the inspector in making his daily inspections, which puts him in a position to give constructive advice to the owner of the station. The inspector should never miss an opportunity to impart this information, because by so doing he is fostering a cooperative spirit between the service station and the weights and measures office.

Before leaving the station we find it helpful to leave a little instruction card with a message to the operators of the equipment. It bears the name, address, and phone number of our Division and contains the following information :

As a gasoline station operator, we wish you to know that good weiglits and measures practices require:

1. That your pump must alwavs start exactly at zero.

2. That indicator's on pumps must be returned to the zero position before starting a delivery.

3. That your pumps should be tested the first thing each day.

4. That the visigauge and numerals be kept clean.

5. That all liquid and oil measures must be tested and sealed befole being used. (This is done at our office without charge.)

6. That you do not use a pump which seems faulty. Call your service department immediately and then report the matter to the above Division.

As we go about our duties day after day, telling businessmen what their obligations are, and what they must and must not do, I believe we sometimes lose sight of the fact that we too have obligations to the businessmen and to the manufacturers of weighing and measuring equipment. I will give three examples:

1. Five- and Six-Quart Liquid Measures: As all of you know, our H4t Code prohibits the commercial use of five- and six-quart measures. When this specifi cation was written there was no real need for a size other than today's legal sizes. Fol mole than twenty years automobiles have been built witl crankcase capacities of five and six quarts. All the popular makes of cars today, except Ford, have a capacity of five or six quarts. In order to change oil in one of tlese cars, if he is using liquid measures, the opelator must use a four and a one quart or a four and a two quart measure, if he is to stay within the law. I have been asked on numerous occasions why we do not allow these measures to be used, and frankly, gentlemen, up to this time, I have been unable to give them a satisfactory answer. It is their belief that it hinges on a nuisance requirement, which produces nothing in benefits to consumer welfare. They need and are asking for measures of these capacities.

2. Type Approval: It is my opinion that when a manufacturer makes a measure that is approved in one or several States, who have adopted the H44 specifications, he has a perfect right to assume that it should be approved by all the States who have adopted these same specifications. Recently a questionnaire was sent to three different States, who enjoy very good weights and measures supervision, asking if they would approve one certain type measure. One already had approved it in his jurisdiction, one would not allow it in his telritory, and the other was not familiar with the measure sufficiently to pass judgment. I can see no good reason why type approval should be handled differently than toler- 
ances or any other $\mathbf{H}+4$ specification. When conflicting opinions exist, among officials well up in weights and measures supervision, my suggestion is that the decision should be made at the National Conference level.

3. Type Approval Markings on Measures: I have always believed that any approval stamp on a measure should be placed there by a weights and measures official, and also, that an approval stamp should not be put on the measure unless the measure conforms. not only to the H.tt specifications, but to the tolerances as well. When a nanufacturer is given permission by a State or city to make a measure with an approval seal stamped on it, the measures are shipped to all parts of the country without the officer's who issue the permit ever testing or seeing the measures. We, as weights and measures officers, know that the stamp is for type only, but the purchaser believes the capacity must be correct, when they have all these approval stamps on them. Many times they are not correct. At the present time, we have in our office several cases of new measures, which we have found to be as much as twelve drams short. The tolerance is two drams. These measures have stamper on them the approval stamp of three or four States or cities. I would not like to see measures such as these being shipped all over the country, bearing our seal of approval.

We have splendid equipment in our service stations in Detroit. Our methods of test and procedure have proven very successful and it is hoped that by this paper and the discussion which may follow, we can arrive at one ideal procedure for an inspector to follow, from the time of his entry into the service station until his departure therefrom. This should result in better uniformity and greater efficiency.

\section{DUTIES OF AN INSPECTOR IN A RETAIL FOOD STORE}

\section{Br F. M. Gleene, Deputy Commissioner, Food and Drug Commission, State of Connecticut}

At the request of your secretary, I have prepared a paper for dehivery at this Conference in which an endeavor will be made to outline the duties of a weights and measures inspector in making a periodic inspection of a typical moder'n retail food store or supermarket.

The inspector's responsibility is to make sure that the weighing and measuring devices weigh accurately and the methods used in the weighing of prepackaged meats, cheese, fruits, and vegetables are correct, and that all commercial transactions are based on accurate weight, measure, or' numerical count.

It is necessary for the inspector to devote a considerable portion of his time to reweighing prepackaged food items, especially those prepacked at the store from bulk stocks. It is necessary that frequent reweighings of representative samples of the various food items and commodities sold in this form be made, and time spent in the reweighing of prepackaged commodities will assure the customer that correct weights and computations will be received when purchases are made.

Special prepack scales are used in the weighing of prepacked items. They are designed and operated to balance out the tare weight of the package or wrapping material before weighing the commodity and computing the cost of the net weight of the commodity weighed. An inspector should be familiar with the operation of prepackaging as well as computing scales. He should have sufficient knowledge on the operation of other types of weighing and measuring devices used in these stores.

In testing computing and other types of scales found in a modern food store, each scale should be examined carefully by the inspector to ascertain if it is functioning properly. Finding no difficulty in its 
operation, he proceeds to test its zero balance. The scale should be tested from zero load forward to its maximum capacity. A backcheck shonld then be made from capacity load to zero load with shift tests of load at capacity and half-load. During the applying of test loads, he must assnre himself that the scale is registering properly on the customer"s sicle as well as the salesman's side. Computations of prices at rarious loads must be rerified to assure the inspector that the scale is operating within tolerance. To avoid moving back and forth from behind the connter to the front of the scale, which consumes much time, the assistance of a second man in this work is a great benefit.

The following procedure is recommended to the weights and measlires inspector entering a retail store for routine inspection, from the time of his entry into the place of business until his departure from the store.

Upon entering the front door of the store, the inspector must be observant at all times. While in the store he must be on the lookout for short weight and improperly labeled packages as well as for inaccurate weighing and measuring derices. Not all violations found are intentional. Some may be due to ignorance or carelessness. Any action taken by the inspector depends on the results of his investigation and the use of his best possible judgment. He should never "jump to conclusions" but listen to both sides of every question or dispute, weigh the evidence, and then make an accurate decision.

His first move is to locate the person or persons in charge, and make lis presence and the purpose of his visit known. In most cases, his risit will be welcomed, provided it is at a time when the store is not crowded. Following a discussion of his visit with the person in charge of the store, he will proceed to test the scales throughout the store including those in the basement and other parts of the building and also the prepackaging scales located in the sections used for prepackaging meats, cheese, and other commodities.

Moving to the first section on the right side of the store, he finds himself in the candy department. As a rule all candy on sale is prepackaged and none weighed at time of sale. He will examine the packages for improper labeling, weighing representative samples of the various kinds on display, especially those packages prepacked on the premises. For purposes of verification of reights, a scale in the adjoining section of the store will be used but not before it has been tested by him for accuracy.

Moving to the next section of the store, which in this instance is the fruits and regetables section, the inspector proceeds to check all approved types of scales found in this department. He will seal those found to be within tolerance and condemn for repairs the scales found to be inaccurate, stating his intention of returning to test these when he has been notified that the scales have been repaired.

Following the testing of all the scales in the fruit and regetable section, he proceeds to weigh up representative samples of prepackaged fruits, nuts, and regetables found in this section. He will also examine packages for improperly labeled commodities, including both the price computation and weight markings on the packages. Finding errors in weight, pricing or in improper labeling, he will notify we person in charge to correct the errors immediately or remove 
from sale any such commodity which he finds is being sold in violation of the State laws or regulations.

Next he moves into the dairy section, where he tests any and all scales found here. A check is made for improper labeling of all prepacked products sold in this department, and the weights and price computations are verified on samples of these items. Included with these food items are milk, eggs, butter, cheese, etc.

Items found in the frozen food section should be checked and examined for improper labeling, together with the verification of declared weights.

Moving into the bakery counter no scale is used there so the weights of bread, cakes, cookies, etc. must be verified by the use of scales previously checked in other departments. A check-up for improper labeling is made in this section.

He next moves into the meat and fish department where he finds nearly all the meat and fish on display in prepackaged form. First he will test the prepack scales used in this section, determining the accuracy of each, condemning for repairs those found inaccurate and sealing those found within tolerance. Representative samples of different prepackaged meats, fish, and fowl will be tested for weight, improper labeling, and price computations. A considerable portion of the time spent in the store will be consumed in the weighing and examining of the samples of the many food items prepacked for sale in this section of the store.

Upon the completion of the inspection of the meat department, he will then proceed to the grocery section, and weigh and inspect for improper labeling all products which he finds there that appear doubtful to him.

After he has completed his inspection and has tested all weighing and measuring devices in use at the store, he should make out a report on his findings. Following a discussion of this report with the person in charge of the store, he will request him to sign the report, and a copy is given to him for reference and file.

If repairs or changes must be made in equipment or methods used, the inspector reminds the proper attendants that he expects them to be completed in ten days, at which time he will return to check up on recommendations made in his report.

Having made his report in triplicate, he forwards the original to his office, and keeps a duplicate for his own file and future reference.

Mr. J. T. Knnnedr. On prepackaged commodities where there is bleeding, do you consider the blood as a part of the net weight? In the case of frozen lobster tails, when defrosting occurs there is water in the package; is this water part of the net weight?

Mr. Greene. With respect to the blood, my answer would be "Yes." I am not sure about the water-I am not an authority on that-but if this has not leaked out the package weight should not be changed. I might mention that a concern in New Haven bought some imported frogs' legs. The cases were labeled to show a contents of 30 pounds. The dealer bought fourteen cases, but this commodity does not sell in too much volume and he could open only one case at a time. When the contents of a case was thawed out, it weighed 21 pounds. How do you handle these situations? 
Mr. J. T. Kennedx. I require that the declarations be changed. In many places frozen foods are placed on stands, and they defrost; part of the resulting water is absorbed into the tray and part lies loose in the package.

The Chamman. When Mr. Kennedy speaks of such items as water and blood, I think the point is that if these are considered as edible food they are included in the weight. For example, certain canned hams are packed in gelatin; if the can is opened and the gelatin scraped off, there may be a loss of $3 / 4$ of a pound, but the gelatin is edible food.

Mr. Ising. What about wrapped hams? The Federal ruling is that the weight must be shown on the package.

The Chamran. In our State, they must be stripped at the time of sale and sold by net weight. I think you will find that there are about 6 ounces of paper on the ham. The dealer cannot sell paper for 59 cents a pound, but he must unwrap the ham and weigh it net.

Mr. J. T. Kennedy. In Washington we have required dealer's to strike off all weight indications on hams and weigh them at the time of retail sale.

Mr. Tripple. Is it in your law, Mr. Chairman, that a dealer must take the wrapper off a wrapped ham?

The Chamrinan. We proceed under our general net-weight law.

(At this point, at 4:40 p. m., the Conference adjourned, to meet at $10 \mathrm{a} . \mathrm{m}$. IVednesday, May 24, 1950. 


\section{THIRD SESSION-MORNING OF WEDNESDAY, MAY 24,1950}

(The Conference reassembled at 10:05 a. m., A. J. Jensen, Vice President of the Conference, presiding.)

\section{REPORT OF THE SPECIAL CONFERENCE COMMITTEE ON UNIFORM REGULATIONS, PRESENTED BY R. D. THOMPSON, CHAIRMAN}

At the outset may I ask the indulgence of the Conference for the brevity of this report and the seemingly few recommendations which the committee has to ofler. As you know, Mr. J. W. Reese, of Iowa, was originally appointed chairman of this committee, but had to resign due to ill health and the press of other duties. 'The present chairman was appointed by Dr. Condon as of February 8, 1950. This left a comparatively short time for' a comprehensive study of this subject.

In reviewing the paper of $M_{r}$. Lewis $E$. Witt, presented at the 34th National Conference entitled, "Uniformity of Interpretation and Enforcement," it was apparently his idea that a Standing Committee be appointed to draft model regulations, to be promulgated under the Model Law, for adoption or rejection by the Conference and that if such regulations were adopted that they might serve as models for the several States in promulgating similar regulations. These regulations are not to be confused with those pertaining to commercial weighing and measuring devices, as contained in Handbook H4t, but rather would be confined to the field of sales of commodities and interpretation of other phases of the law.

However, the resolution which called for the creation of this committee apparently conceived the duty of the committee to be, and I quote, "to gather" and present to the 35th Conference on Weights and Measures a program of ideas and examples of regulations that may be used by weights and measures officials." "Therefore, the Committee does not feel it was created as a standing committee and has chosen to offer a few suggestions which we feel pertinent, also to suggest certain principles to be followed in the promulgation of regulations.

It was felt that the first step of the Committee should be to conduct a survey to determine the number and type of regulations in force in the several States and principal cities in the United States. Hence a form letter was sent to weights and measures officials in each of the 48 States and to 19 cities and counties assumed to be active in this field. Replies were received from 31 States and from 10 cities. Seven States replying had no regulations other than those pertaining to weighing and measmring devices: of the remaining 24 , regulations varied from a minimum of 1 to a maximum of 34 . Apparently only one of the cities, Washington, D. C., promulgates regulations as such, but many of them enforce State regulations and have a variety of ordinances which are similar ju many respects to the State regulations.

It is erident that regulations are looked on with more favor by the courts in some States than in others. The language of the basic 
weights and measures law is broader in some States than in others, and likewise the interpretation of the law raries from State to State, and one night say somewhat from court to court.

The Committee wishes at this point to show some of the disadvantages as well as advantages of enforcement by regulation. We are of the opinion that an official who takes out a warrant for a violation under a specific section of the law stands a much better chance of obtaining a conviction in the average court throughout the country than he would on a regulation promulgated under the same section of the law. However, if the regulation las the backing of the National Conference and the recommendation of the National Bureau of Standards, his chances for a conviction of violation of a regulation would be improved materially, particularly if the State has the Model Law.

Regulations have the distinct advantage of being more flexible than laws. If it appears that a regulation, after due trial, is impractical or undesirable, it may be changed or repealed without recourse to legislative channels. It is also possible to enact through regulation many desirable and more or less technical matters, that mould never live through a legislative committee loaded with work and limited through lack of time for proper consideration. A case in point is our specifications, tolerances, and regulations for weighing and measuring devices. How many of you would guarantee to pilot this document through your State legislature in the form of a bill, and have anything workable left?

Regulations may and should be expressed in simpler and clearer language than is necessary in a law. It is also desirable that regulations be as brief as possible; howerer, if another sentence or paragraph serves to clarify a point, it should be inserted.

The committee also recommends some other principles which we feel should be followed in drafting regulations.

First, the regulation should bear a number, and clear, brief, descriptive title at the top of the page. This should be followed by stating the authority for its promulgation as "Authority: Section 1485 (19) Chap. 61-Code of Va. 1920," this to be followed by the effective date as, "Effective: January 19, 1950." It is noted that some States follow the practice of quoting the specific act authorizing the regulation. This would seen to be a good practice and might be followed to advantage. Yon will of course want to be guided in such matters by your legal advisor and the custom in your respective States.

Second, some regulations deal with matters of a more or less local nature or peculiar to certain sections of the comntry. If the problem to be regulated is also a problem in adjoining States, it would be wise to consult your neighboring officials and see what action, if any, they have taken or plan to take on the problem. It is also important to be sure that your regulation is not in conflict with regulations of other enforcement agencies in your own State, such as Health Departments, Dairy and Food Dirisions, Pharmacy Boards, etc., or with some Federal regulation.

Third, it is recommended that in those States which have authority under the law to regulate methods of sales of commodities, a careful study of the Reports of the National Conference Committee on this subject be made. Oflicials drafting such regulations may be materially aided by following the recommendations of this committee, which appear in the Conference Reports over a long period of years. 
Many States having adequate Weights and Measures Laws include a Net Container Act, i. e., an act requiring that all packaged goods bear a declaration of net contents. 'This act, in all instances where the model law has been followed, contains a provision that "reasonable variations or tolerances and also exemptions as to small packages shall be established by rules and regulations."

Most of these States have enacted some sort of regulations under this act, and there is as much lack of uniformity in these as can be imagined. Some States liave set up a long list of commodity tolerances, others a flat percentage basis, and in many it is specified that the variation in weight be as often over as under.

This Net Container Act in the State laws parallels similar sections in the Federal Food, Drug, and Cosmetic Act, with the chief difference being that the Federal Act applies only to packages of foods, drugs, cosmetics, whereas some State Net Container Acts cover all commodities.

The Federal Food and Drug Administration has promulgated a comprehensive regulation under the act, and all foods, drugs, and cosmetics in packaged form which move into interstate commerce are subject to the provisions of this regulation. While as individuals we may not agree with this regulation, or may have a better idea, it is a fact that such products manufactured or packed in our respective States which pass into interstate commerce are subject to the Federal requirements. From the standpoint of sound business practice, adoption of similar regulations seems desirable. Thus any manufacturer, distributor, or packer would be assured that if his product met the requirements of the Federal regulation it would also be acceptable to the State, and vice versa. Further the States would have the advantage of calling on the Federal Food and Drug Administration for interpretation of certain sections of their regulation, and court decisions in relation thereto. It would seem, therefore, to be the part of wisdom for the several States to consider adoption of regulations as nearly in agreement with it as possible.

The State of Texas has promulgated a regulation under the Net Container Act which parallels the Food and Drug regulation, with some slight changes. Many States have followed the Federal regulation in part as pertains to exemption of small packages.

Copies of the Texas Net Container Act may be obtained by writing the Division of Weights and Measures at Austin, Texas, and of the Federal Food, Drug, and Cosmetic Act and regulation by writing the Federal Food and Drug Administration, Washington, D. C.

I wish to take this opportunity of expressing the Committee's appreciation for the cooperation of the various State and city officials who sent us promptly information requested pertaining to their regulations.

\section{R. D. Triompson, Chairman, C. I. HoEL, \\ J. W. ReEse, \\ E. C. WESTwOod, \\ Special Committee on Uniform Regulations.}

(It was moved and seconded that the Report of the Special Committee on Uniform Regulations be adopted, the question was taken, and the motion was agreed to.) 
REMARKS OF DR. LYMAN J. BRIGGS, FORMER PRESIDENT OF THE NATIONAL CONFERENCE ON WEIGHTS AND MEASURES

The Champar. I know that all of us are glad that there is with us this morning one of our dearest friends, a man who has had more to do with weights and measures in the United States than anyone in the past. I refer to Dr. Briggs, formerly Director of the National Bureau of Standards and President of this Conference. Will you come forward, Dr. Briggs?

Dr. Briggs. Gentlemen, I greatly appreciate this welcome. In this work we are confronted with the proposition of keeping on our toes, constantly trying to learn more. I notice that the next paper on the program concerns electronic weighing devices. Whoever thought that we would have to go into the radio business or the electronic business in connection with the staid and sober program of weights and measures! But that is what confronts you, gentlemen. So I am looking forward to seeing a group of electronic engineers come out of this organization. Thank you very much.

\section{DEVELOPMENTS IN ELECTRONIC WEIGHING}

By C. L. Richard, Supervisor of Scales and Weighing, Packers and Stoclyards Division, U. S. Department of Agriculture

In the progressive development of modern weighing appliances where rapid, precise, and economical determination of weight are paramount objectives, it was inevitable that the vacuum tube, the servo unit, and the principles of electronics should find practical application. Tried and proven for instrumentation and control purposes in the laboratory, in communications, and in military use, these useful tools of the electronic age are now being applied to refine, expedite, and simplify the ancient and generally lionorable art of weight determination. Today, in limited number and for special purposes, there are in use large-capacity weighing scales which employ no levers, pivots, weighbeams, pendulums, racks, pinions, extension springs, or other mechanical components common to the conventional types of scale with which the weights and measures official is familiar. "Electronic scales" and "electronic weighing" are names generally used when referring to the new devices and methods, so I shall make use of those same terms in this discussion.

Your Conference Secretary suggested to me that a non-technical discussion of electronic scales, with explanation of their features and operating principles, would be of interest to you because devices of this general type presumably will find practical application in channels of trade where they will be subject to your jurisdiction. Accordingly I shall endeavor to describe for you, in the plain language of a scale engineer, the fundamental features, design principles, and performance characteristics of one representative type of electronic scale which was developed originally, in cooperation with my Department, for weighing livestock at public stockyards and which is now also being used in other special fields of weighing. 'The particuIar type of scale I shall describe represents but one generic type of electronic scale; other's, employing analogous principles in varied types, are in course of development by several scale manufacturers. $90+381-50-5$ 
It is pertinent, first, to consider why we are concerned to weigh objects and how we establish their weight value. We weigh them in order to determine their mass, the quantity of matter contained in them. We accomplish that purpose, not by direct quantitative determination as in metering fluids but, indirectly, by measuring the forces which gravity exerts upon them. Thus, all weighing devices are primarily force-measuring instruments. With the simple balance, as with all forms of lever scales, we employ a comparison method, counter-balancing load forces of unknown value with the forces acting upon a standard or unit of known value to evaluate the former. With the spring scale we directly measure forces by observing their effects upon a previously calibrated elastic element whose deformation, we know, is in direct ratio to applied load forces.

The research engineer and the laboratory technician, when experimentally studying the properties of materials or the behavior of structures, use other forms of special force-measuring instruments which are known as strain gages. One such strain gage, perfected in recent years and possessing superior qualities of sensitiveness, accuracy, and constancy, is called a "Resistance-Wire Strain Gage." This laboratory instrument, in a specially modified and refined form, is the basic force-measuring component of one typical electronic seale and I shall therefore undertake to explain its construction and its function.

To visualize a resistance-wire strain gage consider, if you please, a small upright steel column mounted upon a rigid support. Any load applied to the upper surface of the column will compress it and cause a reduction in its leight. If loading is confined within the elastic limit, the compression or other deformation is directly proportional to the applied load. For example, a load of ten pounds will actually compress such a column approximately one five millionth of an inch, and twice that load will precisely double the degree of compression. Thus, you will perceive, we have a true spring scale, but the load effects are too minute to be measured by ordinary means. However, if we firmly bond to the column a grid work of fine resistance wire so that the wire reacts to the column compression, the wire's resistance will decrease in direct proportion to column deformation. That is to say: The change in resistance is a direct measure of the column deformation which, in turn, is a direct measure of the applied force. Connect the resistance wire in an electric circuit with a sensitive galvanometer, and we may utilize that latter instrument to weigh loads imposed upon the column. It is true that the minute resistance changes are too small to be measured without fine laboratory instruments and under controlled conditions. To meet the accuracy and precision requirements of a good weighing device it would be necessary to measure the gage resistance to the nearest tenthousandth of an ohm. It is here, in this critical phase of the instrumentation, that the special knowledge, experience, and skill of the electronic engineer make their chief contribution to the scale design. The problem is to accurately measure the faint electrical impulses resulting from load changes, amplify them many thousand times without distortion, totalize the effects coming from individual gages in 
an assembly, exclude the influences of stray or induced voltages, and finally actuate a motor-driven servo mechanism to register the true net results in terms of weight on a remote dial and printer. The involved technic and special means by which this is accomplished can not be discussed in these remarks, but the virtue and the function of electronic circuits and elements is to accomplish just such tasks. The successful solution of the problem is remarkable but not mysterious, marvelous, perhaps, but not magic. Actually, to perform the described task is no more phenomenal an achievement than the manifestations we observe daily in radio and television. Consider, as a comparable example, how the same principles of controlled electronic amplification enable us to capture from the ether a vagrant high-frequency wave, amplify it several thousandfold, and bring to our homes the voice of a distant singer, the spectacle of a baseball game.

From consideration of the principle of the strain gage which forms the primary weight-measuring element, we may proceed now to examine the components, assembly, and installation of a practical scale constructed on the described principles. For this purpose let us consider a particular large-capacity scale which represents one type of electronic weighing appliance. Presently I shall show you some slides to illustrate my remarks.

Strain gages, in the form I have described, are assembled in matched pairs within a small metal pedestal or cell about the size of a pint fruit jar. Inactive dummy columns and gages are included and connected in a Wheatstone bridge to eliminate variable effects caused by resistance changes in cables, switches, and plugs, and means are incorporated for neutralizing the effects of temperature and humidity changes. Four such cells, each comprising a separate weight-measuring element but carefully calibrated and matched, support the scale platform near its corners.

Shielded flexible cables connect the cells to a central indicating unit which may be located at any convenient position. Loads applied to the platform and transmitted to the cells create electrical impulses which are relayed to the indicator and cause a condition of unbalance in the electrical measuring circuits. 'The degree of this unbalance, converted into pounds, is registered on the dial face as a servo mechanism automatically translates the electrical signals into mechanical motion of the indicator hands.

A printing unit completes the assembly. It is connected to the indicating unit by a single cable, and through the medium of special motors of the Selsyn type, motion of the dial indicator hands is translated into rotation of type wheels to position them for printing. Accassory elements, in the form of a switch, a push button for printing operation, an adjustable damping element, and signal lights are provided on the printer unit.

(At this point the speaker showed a number of slides, reproduced herein as figs. 1 to 6 , inelusive, and deseribed the illustrations, as shown immediately below.) 


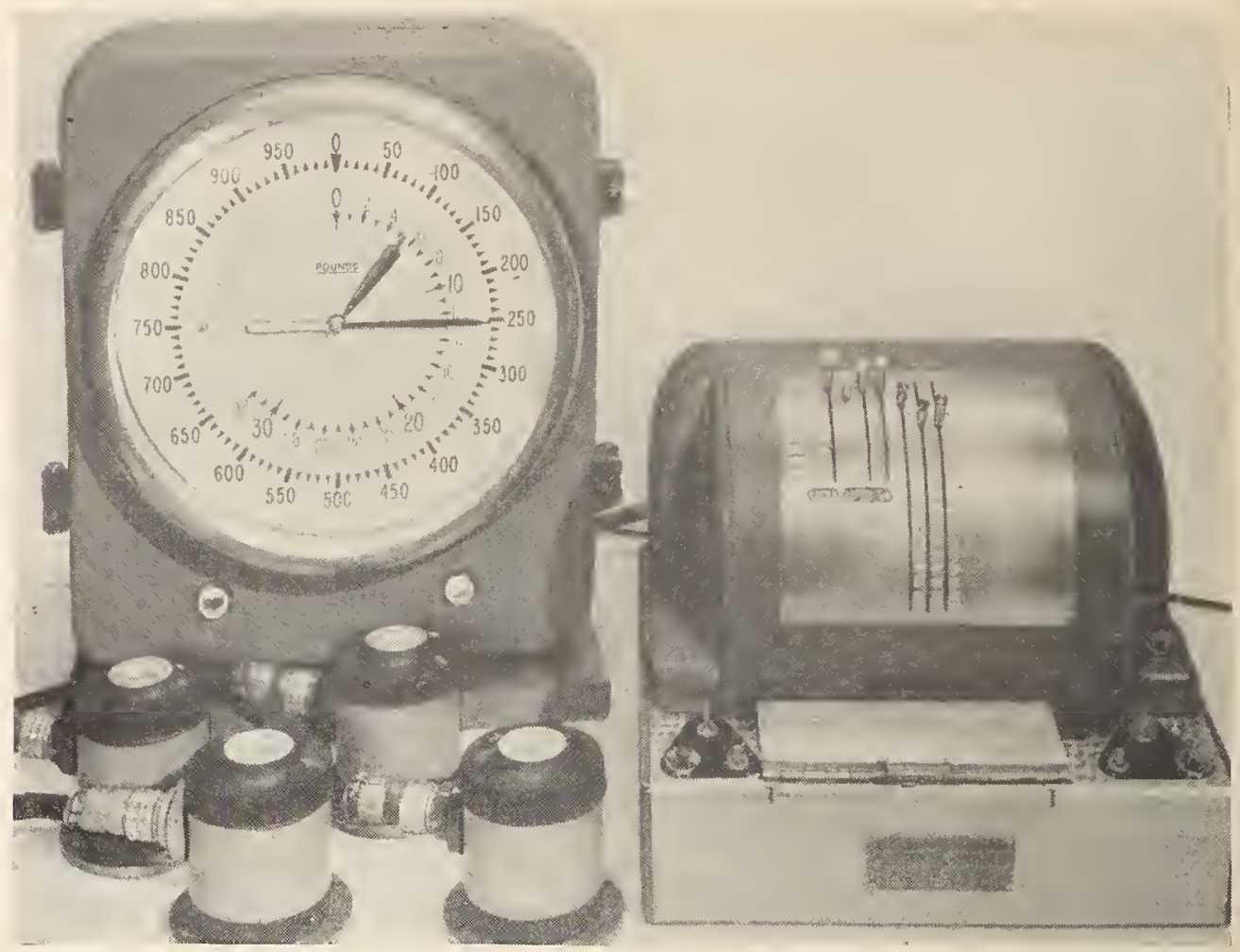

FIGURE 1. Component parts of eleetronie seale.

I should like to make it clear that in discussing and describing this instrument I am using the particular product of one manufacturer only for purposes of illustration, aud I wish to repeat the statement already made that other principles can be applied and al'e being applied experimentally by other manufacturel's.

The first picture (see fig. 1) illustrates all of the component parts of the scale. These can be broken down into three separate classifications. These are the four cells, which I have previously described, which are the primary weightmeasuring elements. Extending from the cells when they are installed under the platform are flexible cables commecting with the dial. This particular dial was designed especially for our use in weighing livestock, where we wanted to measure weights to a precision of 5 pounds up to a capacity of 32,000 pounds. A noticeable feature of the dial is the two-Jaud principle. Actually, the hands are read in the same manner as we read a clock; the short hand indicates 1,000pound units and the large hand indicates 5-pound mnits. I say "5 pounds" because in practice we read between the sraduations. From the dial unit a flexible cable leads to the printing unit.

The next picture (see fig. 2) is an enlarged riew of one of the cells. Machined metal plates, top and bottom, contain between them the upright steel column and the resistance networks incorporated in the unit. Above the cell is an adapter which is designed to insure that loads are applied vertically; this will adjust and center itself, like a self-alining bearing. The termiual connection for the cable to the indicating unit is shown; in the illustration that is covered. In practice these cells are shielded with a plastic tramsparent material to exclude noisture.

The next picture (see fig. 3) illustrates a method which we used for an experimental installation. A temporary support in the form of a steel tripod was placed in the scale pit near each colnel of the scale, the weighbridge was jacked up to separate the bearings and the pivots, and the cells were then inserted so that the weighbridge lested upon the cells rather than upon the levers. In effect, the levers were thus disconnected and the weighbridge was supported by one cell at each corner of the scale.

The next picture (see fig. 4) is an enlarged view of the dial. This illustration is of an early model which was modified later, but I am using it to show the 


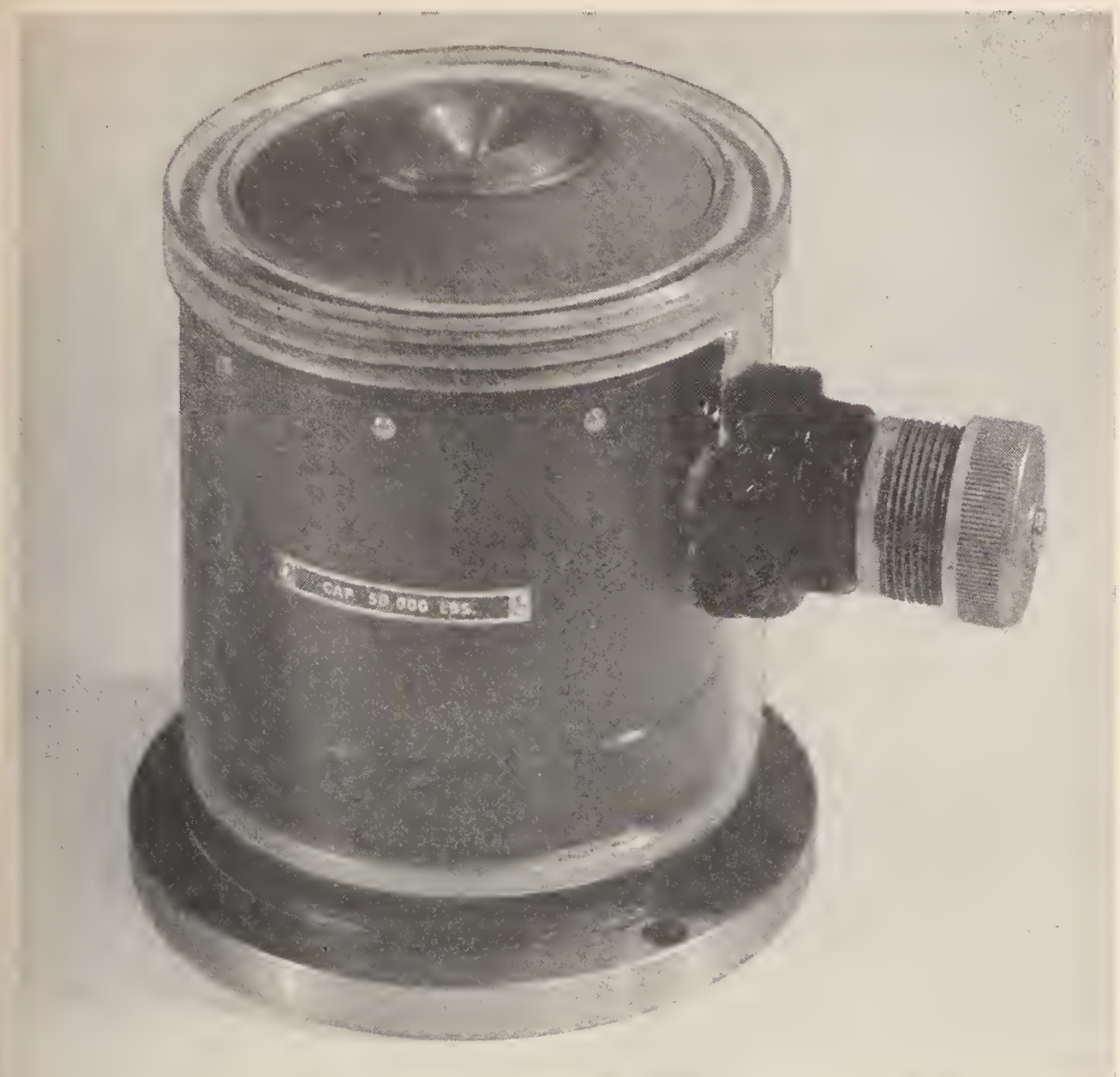

FIGURE 2. Cell used in clectronic scale.

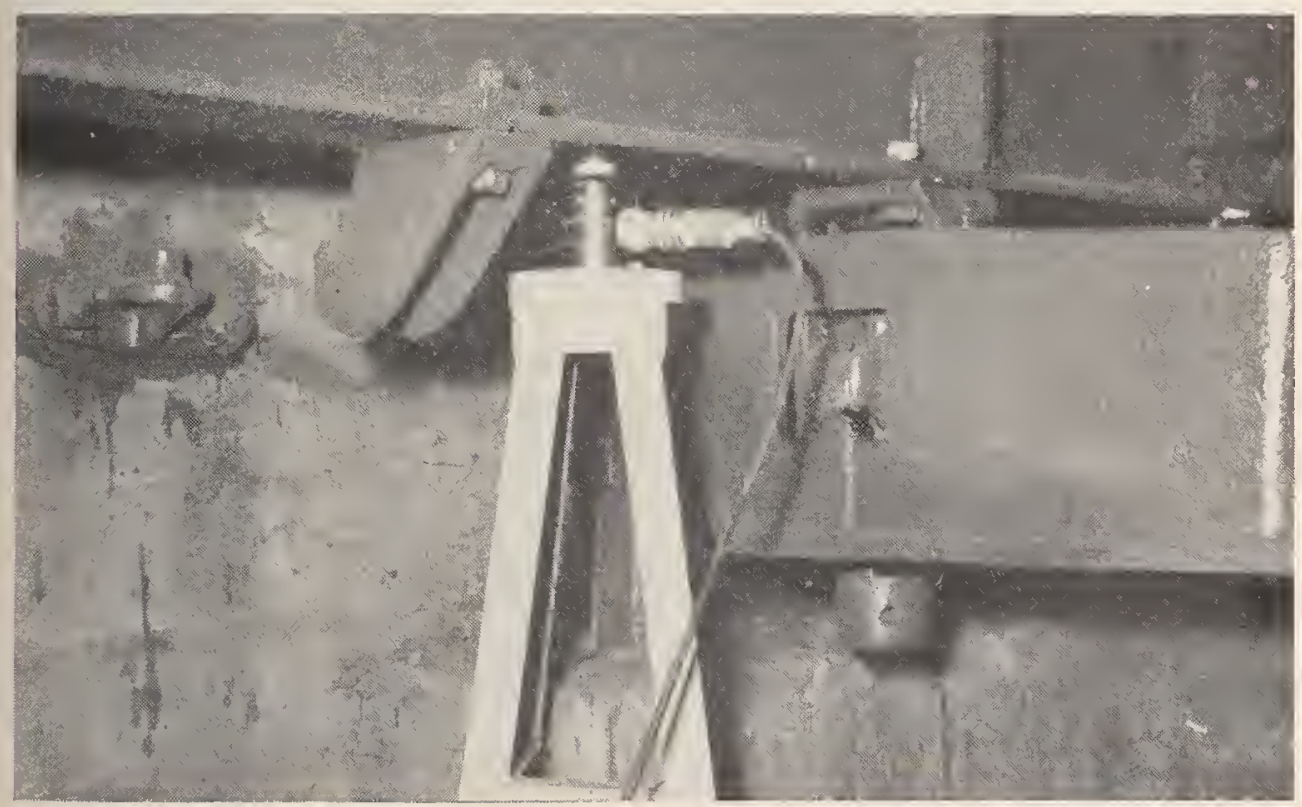

FIGURE 3. Experimental installation of electronic scale, showing one cell in position. 


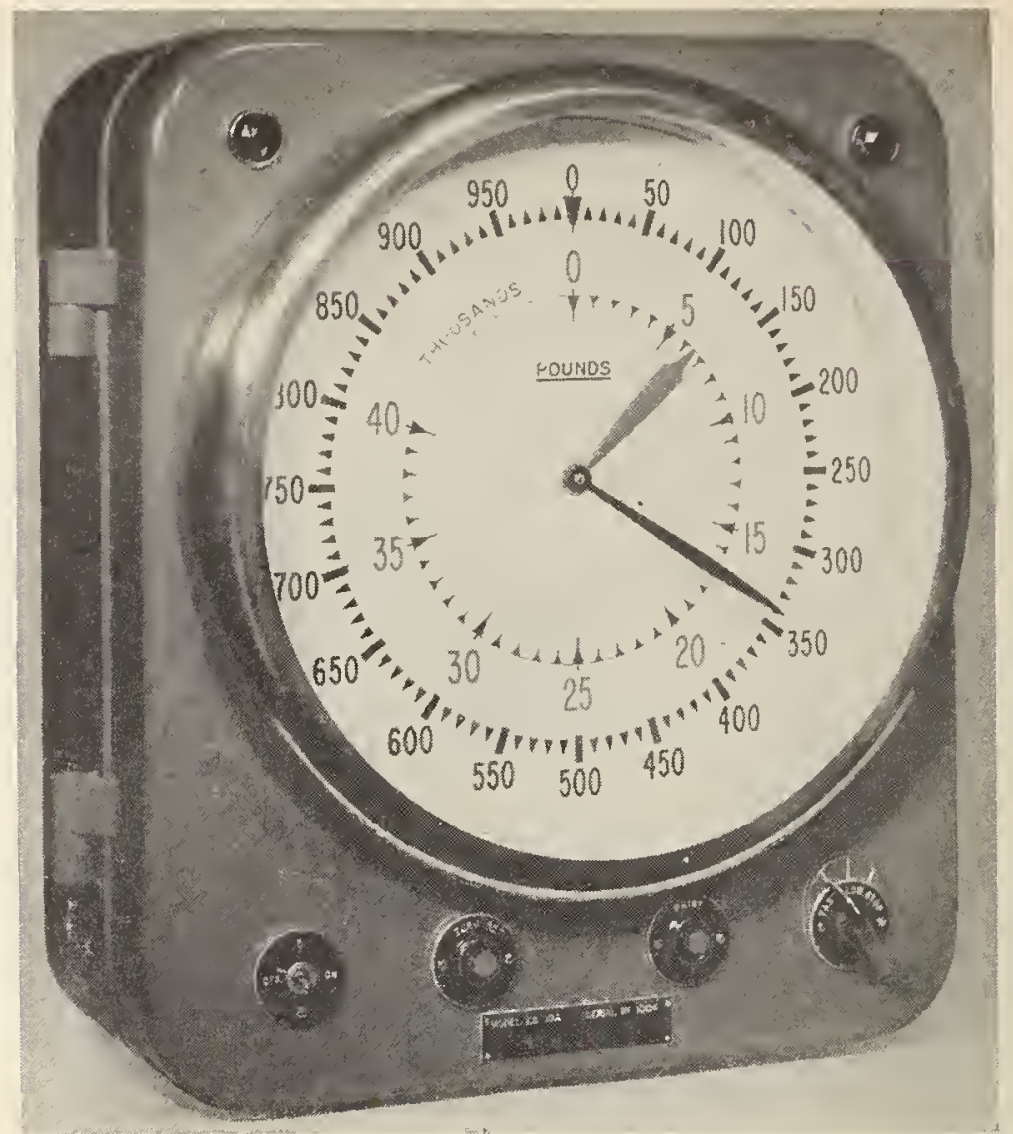

Figure 4. Dial of clectronic scale.

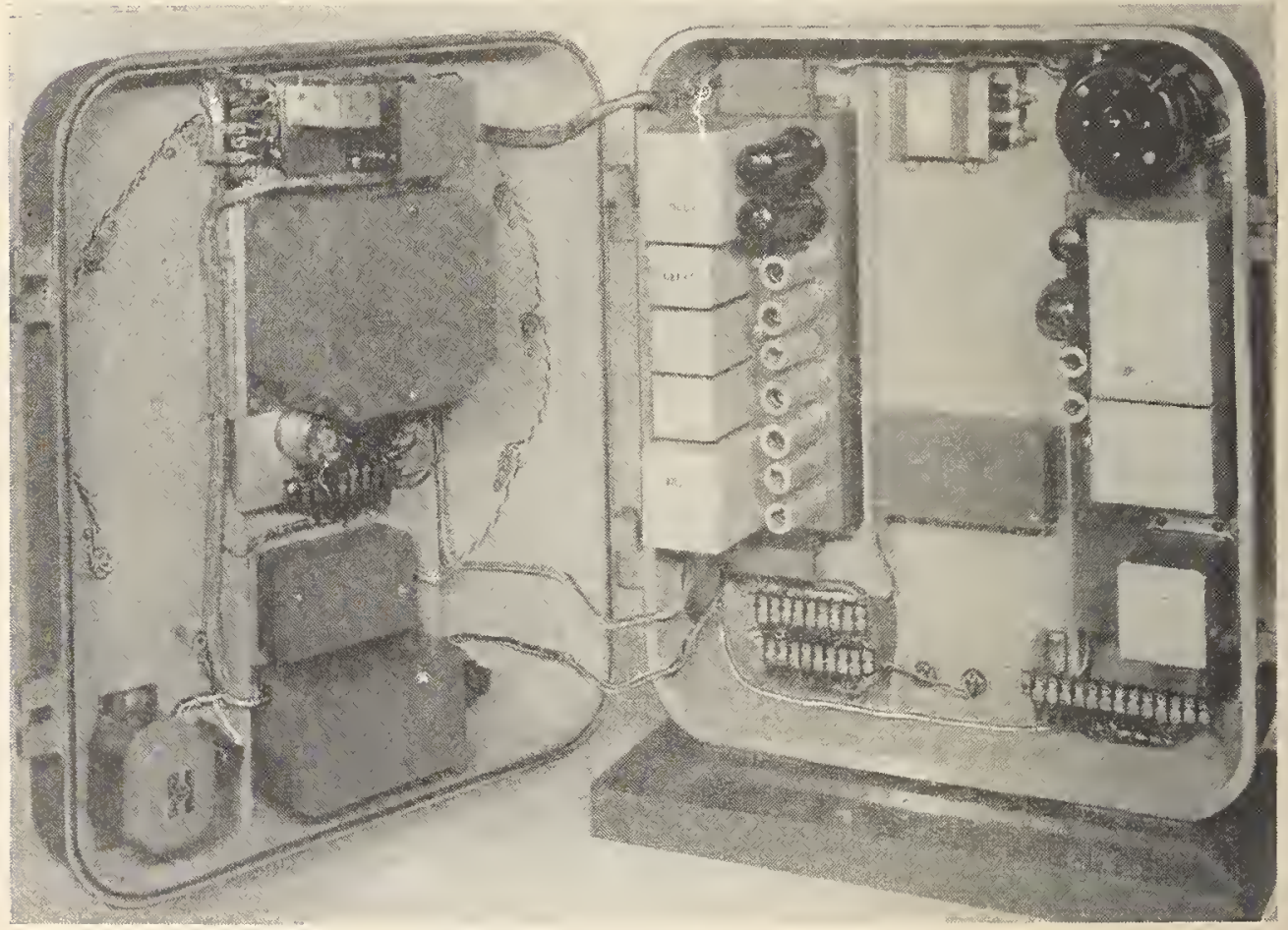

FigURE 5. Interior view of indicator of clectronic scalc. 


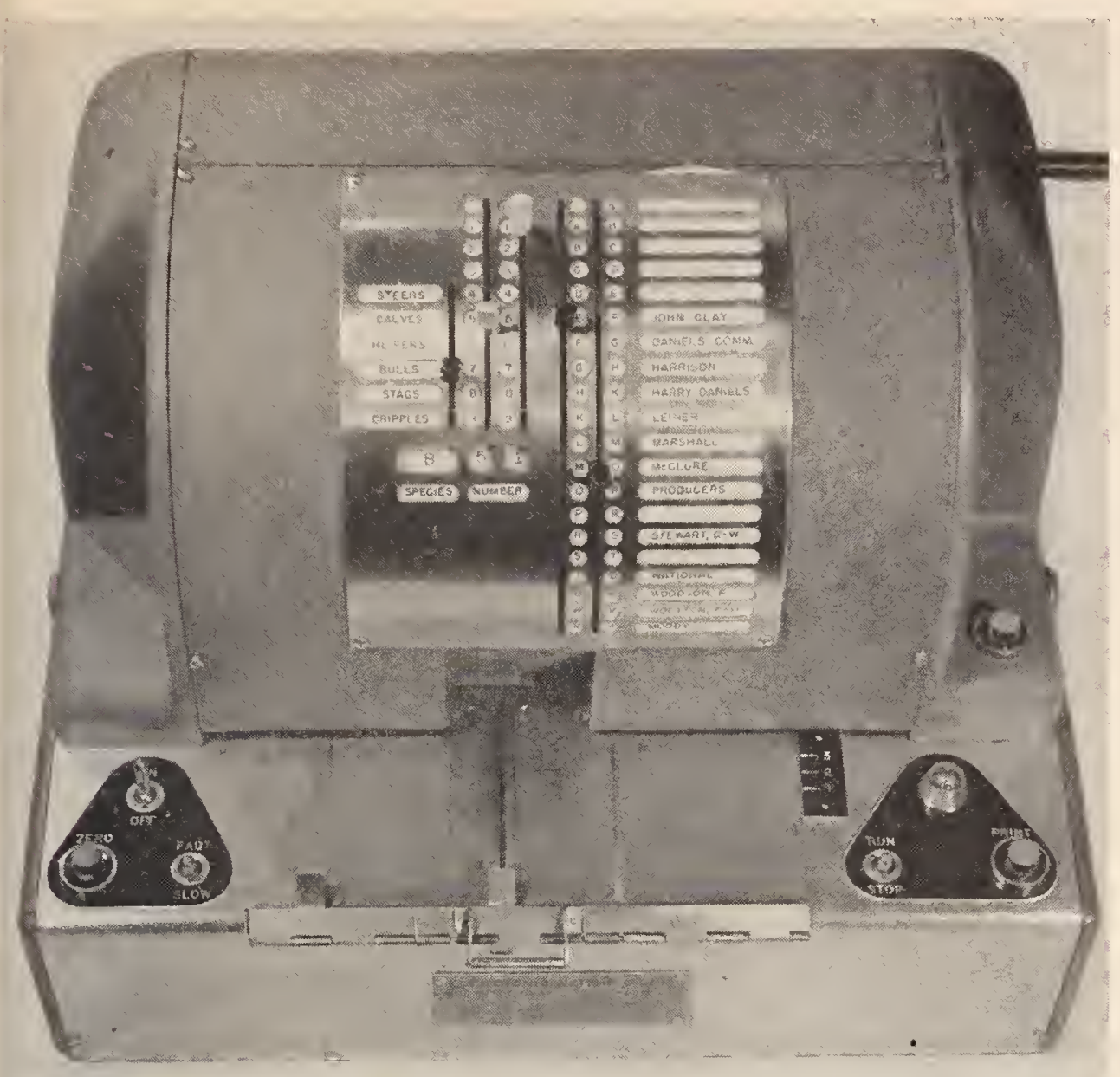

Figure 6. Printer of electronic scale.

controls. A balancing control knob is shown, which has since been replaced by a push-button, which antomatically balances the scale when the load is removed. T'lrere is a printing button which actuates the printer to print the scale readings. There is a damping device to bring the indicators to lest; this is particularly necessary on a livestock scale to dampen the disturbing effects of animal movements which would interfere with good weighing.

The next picture (see fig. 5) is an interior view of the indicator. Instead of the customary assembly of racks, pinions, etc.. these are all electrical units. 'The only mechanical part of this particular scale is the unit which is called the "servo mechanism". It is that part of the instrument which converts the resistance changes into motion of the indicator hands. These units are designed to be replaceable, being standardized and calibrated so that if one fails it can be removed and replaced with a corresponding unit to expedite servicing and minimize interruptions in weighing. Means for electrical adjustment are provided, to obtain effects comparable to those of mechanical nose-iron adjustments.

The next picture (see fig. 6) is an enlarged view of the printer, which is designed particularly for recolding the weights of livestock. The printer operates much on the principle of a check-witer. By setting the proper keys, thele will be printed on the scale ticket the number of animals, the type of animals, the symbol number of the commission fillu by whom the animals are being sold, the year, month, and day, the time to the nearest minute at which the weighing is made, and the sequential number of the scale ticket.

From the illustratious and the preceding explanations, it will be apparent that the significant difference between the electronic scale and the conventionaltype platform scale lies in the circumstance that electrical and electronic means 
are substituted for the usual mechanical ones. Load forces are measured and transmitted electrically rather than through a lever train. Magnification for indication is accomplished electronically rather than with a rack and pinion. Balancing is performcd electrically instead of mechanically witl a poise or pendulums. 'Thus, except fol the single mechanical unit in the indicator unit, there are no moving parts in the assembly and consequently it is to be presumed that the factor of wear, chief source of error in mechanical-type scales, is reduced to a practical minimum. This is onc of the advantages wlich adrocates of electronic weighing emplasize. Some other advantages claimed are the compact nature, light weight, and portability of the component parts which permit ready and economical installation; the entire weight of the units composing the assembly is some 85 pounds, although it will weigh, and weigh correctly and repeatedly, loads as great as 32,000 pounds. The flexible nature of the connecting cables, permitting location of the indicating and printing units at any desired place close to or distant from the platform is assuredly an advantageous feature. Installations of this kind have been proposed with a separate unit whereby the weight could be indicated in the office of the plant manager several hundred feet away. One very practical advantage lies in the fact that rats and other small animals, which often assume positions on scale levers and cause serious weighing errors, cannot significantly affect tle performance of the new-type scale. In the conventional type of scale a 1-pound rat on the transverse lever may exert a load force of 400 pounds on the dial; but with an electronic scale a 1 -pound rat can never register more than 1 pound on the dial. When load is applied to the platform there is instant response of the indicating and printing elements and the customary oscillation interval is eliminated. Since platform motion is negligible, errors caused by interference are not contributed. The vacuun tubes in the indicator unit are standard tubes as manufactured for radio purposes, and they are readily replaceable when necessary.

Anticipating questions which some of you might wish to ask regarding scales of the general class under discussion I may here summarize my own conclusions as to the potentials of electronic scales, their relative costs, performance qualities, durability prospects, maintenance problems, etc. These opinions, it should be understood, a re based upon observation and study of the one particular type I have illustrated. The extent to which they may apply to other products of comparable design and principle will depend upon the degree in which the latter conform to lequisite standards of correct design, precise workmanship, careful assembly and inspection, and correct calibration and adjusting. In that comnection I would offer a warning that the rely lighest standards of manufacturing, inspection, and assembly control must be observed if the product is to yield the quality of performance exhibited by devices in use. Inferior materials, careless fabrication, or faulty inspection and calibration of product, even more so than in mechanical scales, will be reflected in unsatisfactory weighing results and excessive maintenance costs. For these same reasons it is unlikely that satisfactory equipment can be provided at lower costs initially than those for corresponding mechanical scales. In fact, in their present state of development their costs will probably be greater.

Repeated and comprehensive testing of the scales in use has demonstrated quite conclusively that the principle of electronic weighing is proven to be practical and, for some special purposes, distinctly advantageous. Installations in use have been found to consistently meet the accuracy requirements adopted for large-capacity scales. Trial use over extended periods of time under extreme conditions of weather and temperature has not significantly affected performance or caused change in calibrations. Your group will be interested to learn of two special characteristics common to scales of this type. Sensitiveness does not decrease with loading as is commonly the case with lever 
scales but remains quite constant throughout the load range, a desirable quality for many applications. Also, unlike a lever scale in which we may expect the errors to increase with loads when levers are not in exact ratio adjustment, the load-error relation is not linear but remains reasonably constant throughout the full load range. In several tests it was observed, for example, that the maximum error developed under loads of from 100 pounds to 20,000 pounds was only 5 pounds. In fact it seems quite practical to so warp or control the load-error curve of an electronic scale that errors at heavy loads are not significantly greater than those at light loads, a feature of considerable merit.

Questions are asked regarding factors of maintenance, repair, and replacement of parts. To date there has been demonstrated no need for anything more than nominal attention to cleaning and servicing of the electromechanical servo unit of the indicator and the meclianical elements of the printer. In a six months' trial of one installation, maintenance of the electrical elements consisted only of renewing blown fuses, correcting a loose comnection, and replacing a burnedout tube. In a second installation, no failures occurred die to electrical defects but the unit was removed to eliminate mechanical defects in the printer, a condition which has now been corrected permanently. The question of durability is one which must necessarily await further lapse of time, but all present indications are that need for electrical maintenance measures will occur no more frequently than is the practice with mechanical scales.

In some respects, it is not unlikely that the advent of such new equipment in commercial weighing may have impact upon prevailing codes of scale specifications, tolerances, and regulations, for present codes were conceived and developed with lever and spring scales in mind. In consequence, some technical provisions, referring specifically to levers, weighbeams, and other mechanical items, will not be applicable, and I therefore offer the suggestion that cognizance be taken of the circumstances when the issue of compliance or approval may arise.

Summarizing comment upon the general subject it can be said that there seems to be no immediate prospect for wide employment of electronic-principle scales in commerce. Certainly, however, as these newly developed devices pass their present proving-ground tests and trials in special fields of nse, their applications to commercial and transport weighing can be expected. Some are in use now for weighing freight cars in motion, for weighing bulk coal at the mines, for weighing billets in the steel mills. Unquestionably since the induction and capacitance principles can be employed as substitutes for the resistance principle already applied, variations in type may be anticipated. If these measure up in quality to the performance exhibited by the new ones in use, and if the questionable factor's of maintenance, durability, and reliability find satisfactory solution, they hold promise of bringing closer to realization the ultimate of instantaneous weight determination which is the objective of every scale engineer, and the ideal of constant weighing accuracy which is the result desired by all weights and measures officials.

Mr. RICHARD. Since preparing my paper I have learned that the National Bureau of Standards recently procured equipment designed 
and constructed on principles similar to those which I have described, but omitting the antomatic indicator and printer. 'This equipment is intended to be used in calibrating elastic load-measuring devices for loads exceeding the capacity of the dead-weight machine.

That suggests to me something still in the field of speculation. I can visualize a unit constructed on electronic principles, sealed and calibrated, and used to test scales of one type or another without the use of standard weights. For example, if such a unit were applied on a platform of a scale the true weights of unknown loads would be indicated by the instrument and these could be checked against the indicated weights on the scale, thus providing a satisfactory test of the scale accuracy.

Mr. BAdcom. To how close a tolerance can these cells be manufactured, from minimum to maximum loads?

Mr. Ricimard. In our tests of experimental models, and in trials of several months, we applied the regular tolerance for large-capacity scales, applying no tolerance less than 5 pounds. Under all tests at all times the device remained well within the tolerances; the errors did not increase with the load as is commonly the case with the lever scale.

Mr. Badcon. In the replacement of a cell which had failed, would all of the cells have to be sent back to the factory for balancing, or could a satisfactory replacement be made of the single faulty cell?

Mr. Richard. The practice at the factory of this particular manufacturer is to calibrate each cell individually. Then they are matched. Replacement of a cell which went bad would involve nothing more than removing the old cell, installing the new one, and connecting it up.

Mr. WrtT. You have said that in using these cells, one is placed at each corner of the scale platform. With modern platforms being 50 to 60 feet long, would four of these cells be enough, or would six or eight be required?

Mr. Richard. In the application I was referring to, we had a maximum platform length of 26 feet, and we used four cells. In one railway track installation where cars are being weighed in motion, I believe the scale length is 62 feet; eight cells are employed, two being placed at each corner. Deflection effects are less noticeable than they would be in the case of a lever-type scale. The adapter absorbs the effects of deflection and transmits the loads vertically. Cells are very sensitive to off-center loading, and it is necessary to keep the load forces applied rertically to within $2^{\circ}$; they will stand an offcenter load of $2^{\circ}$.

\section{REPORT OF THE NATIONAL CONFERENCE COMMITTEE ON TRADING BY WEIGHT, PRESENTED BY J. F. TRUE, CHAIRMAN}

The Committee has not been rery active, but we did have a meeting yesterday and have the following report to present to this Conference.

The Committee feels that there is some interest in the proposal to sell grains on a weight basis. Information presented at our Committee meeting shows that feed manufacturers, seed dealers, and weights and measures officials who have been contacted are in favor of this proposal, and that some States on the west coast are at this 
time using the hundredweight rather than the bushel as the legal and customary basis for trade. The Committee realizes that the grain trade would have to revolutionize its bookkeeping and records if the bushel were to be dropped and the hundredweight substituted. The Committee would like to continue its activities, and probably call on each State for a report by mail on prevailing conditions.

The Committee recommends, therefore, that it be continued for another year to give the opportunity for further study. It is hoped that a more comprehensive report can be made in 1951 .

(It was moved and seconded that the Report of the Committee on Trading by Weight be adopted, the question was taken, and the motion was agreed to.)

\section{TESTING EQUIPMENT FOR LPG MEASURING DEVICES}

REMARKS OF J. E. BRENTON, CHIEF, BUREAU OF WEIGHTS AND MEASURES, STATE OF CALIFORNIA

Liquid petroleum gas (LPG) as generally sold in the United States is either a mixture of Butane and Propane commonly spoken of as Butane or straight Propane and called such. Liquefied petroleum gas is secured directly from the oil fields and is also obtairied during the process of refining. Under the general heading of LPG we have various brand names, for example, Shellane, Flamo, Liqui-Gas, Bu-Gas, Skell Gas, Rulane, Green's Fuel, and liundreds of others. In colder climates, propane, because of its low boiling point is used, as are also LPG mixtures containing high percentages of propane. In warmer climates there is a tendency to use more butane, which has a ligher boiling point than propane but also has a higher heat value.

As a general rule the LPG that is sold for domestic use in small containers (5 gallons to 50 gallons) is either straight propane or a mixture containing a high percentage of propane, while the LPG that is sold in larger containers or delivered by vehicle tanks is a mixture of propane and butane. The sale of straight propane or a mixture containing a high percentage of propane does not apply to utility, industrial, and motor-fuel use, because where vaporization is done by hot water, steam, or direct heat, the low boiling point of propane is of no advantage.

In deciding which type of fuel to use, the careful dealer should take the following points into consideration: Propane contains about 91,000 Btu (heat units) per gallon. It vaporizes or boils at about 43 degrees below zero Fahrenheit and due to the high vapor pressure produced by summer temperatures, it must be stored and transported in container's built to withstand high pressure.

Butane mixtures average about 100,000 Btu per gallon. These mixtures vaporize at temperatures ranging from zero degrees Fahrenheit to 32 degrees above zero. In this range of temperature, there is a tendency to boil out the propane content. A butane mixture produces comparatively low vapor pressures in warm weather which permits the use of containers of lighter construction than those used for the storage and transportation of propane.

LPG in the liquid state expands and contracts with changes in temperature in the same manner as gasoline and other volatile liquids. The coefficient of expansion of LPG is approximately twice that of gasoline, and in preparing for the storage and transportation of this 
commodity, ample allowance for expansion must be provided. In the vapor state, LPG follows Boyle's Law of Gases and compresses into a smaller space with increased pressure.

A gallon of butane mixture will produce approximately 34 cubic feet of vapor at atmospheric pressure, and with approximately each 15 pounds of pressure applied, a volume of gas equal to the original will be compressed into the same space. A gallon of propane will produce approximately $361 / 2$ cubic feet of vapor at atmospheric pressure.

The greatest volume of LPG is used for domestic use such as cooking, heating, water heating, and refrigeration, and a considerable amount is used for agricultural purposes, namely, tractor fuel, dehydrating, processing, drying, brooder fuel, and pumping. Industrial plants and stand-by plants are also large users of LPG and during peak-load periods the fuel is mixed with air and used in lien of natural gas.

It is an accepted fact that all mechanical devices wear out sooner or later, and because I.PG is a dry fuel with practically no lubricating properties, it is not surprising that the wear of the meters being used for the measurement of this commodity is much greater than would be the case if the same meter's were being used for the measurement of diesel fuel or stove oil.

If proper installation procedure is not followed, a meter may pass vapor and register it as liquid, cheating the buyer in about a 65-to-1 ratio at 60 pounds pressure, or the meter may bypass a considerable amount of liquid thus cansing the seller a loss.

Up until a few years ago, inspections concerning the accuracy of LPG dispensing devices were sketchy and inadequate. A few of the counties made laudable attempts to inspect these devices, but the majority of the county weights and measures officials paid no attention and left any inspection service up to the respective dealers and distributors. The producer claimed shortages, the dealer and distributor either had shortages or set the adjustment on their meters so that the consumer received short measure, and the net result of all this maneuvering was a flood of complaints, each group claiming that the other was stealing their eye teeth.

At the present time in the State of California, two methods are being used for checking the accuracy of LPG meters. The County of Los Angeles is using the gravimetric method (weight) and the State of California and three counties, namely, Tulare, Kern, and Fresno, are using the volumetric method (liquid volume). (See figs. 7 and 8.)

The gravimetric method requires the following equipment: An LPG container, with a minimum net capacity of 50 gallons, mounted on a scale, which in turn is mounted on a trailer. The accessories required are: An LPG pump, an explosion-proof electric motor, a device for determining the specific gravity of the product, necessary hoses and connections for filling and evacuating the container, thermometers, pressure gauges, tools, and adapters as may be required, pamphlet containing conversion tables, a sturdy pair of synthetic rubber gloves, a pair of asbestos gloves with elbow-length gauntlets, and last but not least, fire extinguishers. 


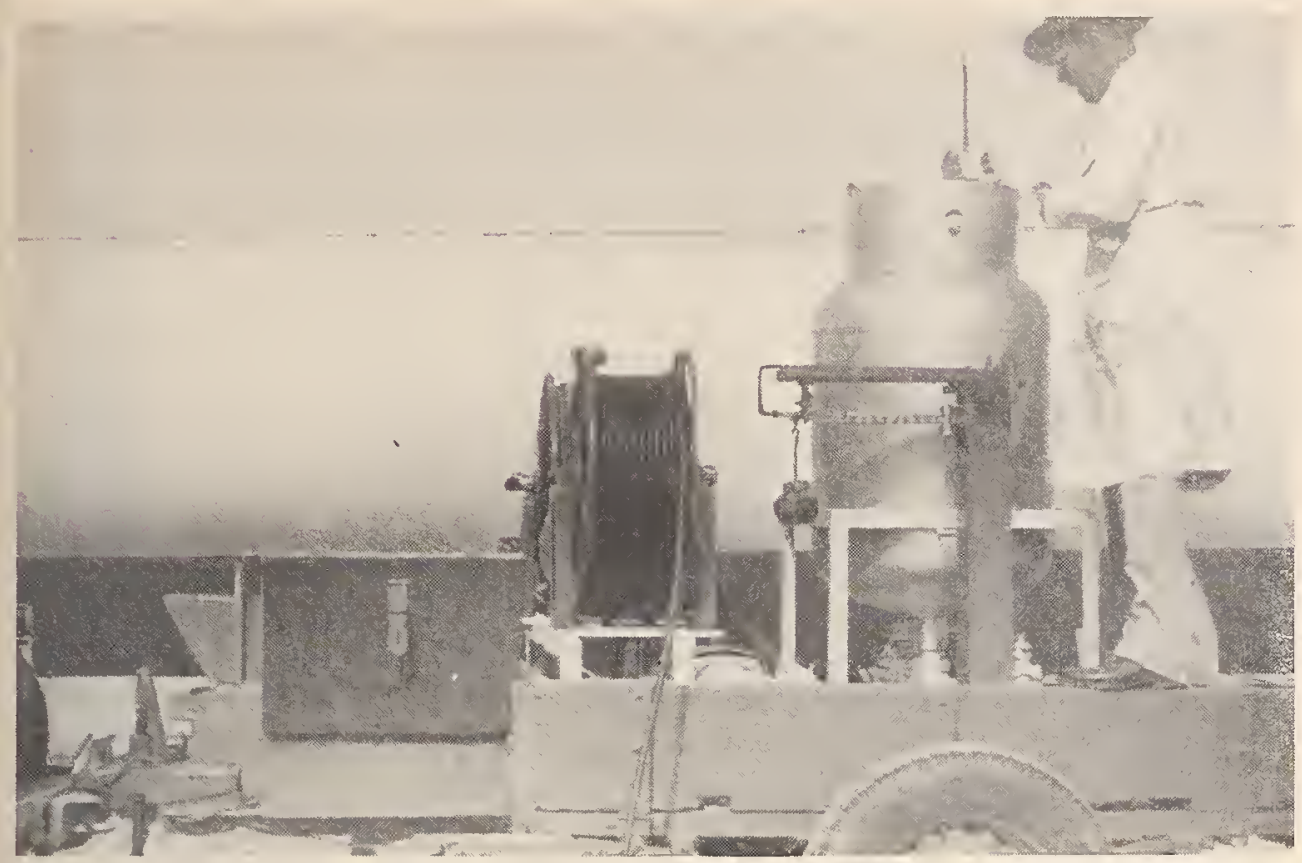

FIGURE 7. Gravimetrie-type LPG-meter prover-County of Los Angeles, Ualif.

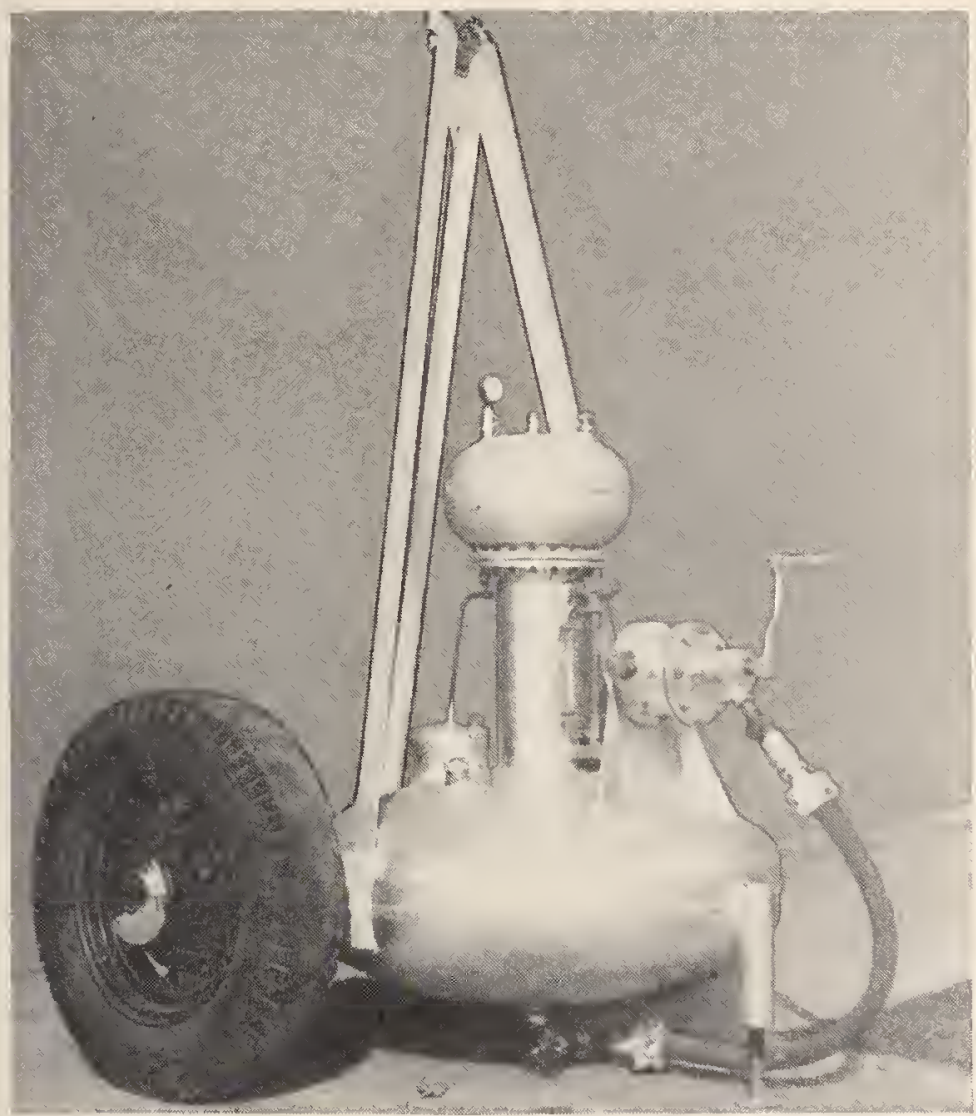

Figure S. Tolumetrie-type LPG-meter mover-County of Tulare, Calif. 
Before making any test, the metering equipment that is to be inspected should be checked for the following:

(a) Sufficient LPG in the supply tank to make the test.

(b) Meter-indicating elcments readable, operating freely, and readily returnable to zero.

(c) Adequate means to prevent the passage and registration of vapor. The pressure differential valve or spring chcek slould be set to exert a back pressure of between 10 and 15 pounds.

(d) Meter correctly installed with vapor-eliminating lines and pump bypass returning, preferably, into the main tank or into the liquid lines, but not into the vapor-return line.

(e) Vapor-return line installed so that vapor can flow in either direction, meaning no check ralves in the line.

(f) The meter should be an approved model.

(g) All equipment should be in the clear at least 50 feet from tholoughfares or important buildings. The equipment should be in safe operating condition, meaning no lcaks, no unauthorized visitors present, no smoking or open fires. The best place to conduct a test is at the distributor's bulk plant or station where reasonable caution is practiced and familiarity with LPG is existent, and where an authorized representative of the distributor or the distributor himself is present to operate the dispensing equipment.

The procedure in making a test using the gravimetric method is as follows:

1. The trailer carring the scale and test ressel is leveled and blocked.

2. The test vessel is filled with $L P G$ vapor through the vapor line.

3. The scale is adjusted for zero balance, which in this case includes the weight of the container and vapor contained therein.

4. The filler hose is connected, and according to the meter reading, exactly 50 gallons is pumped into the test ressel.

5. The temperatire of the LPG is recorded at the start of each test, at the halfway mark, and at the completion.

6. Also, during the filling period, the rate of delivery is recorded at the start and at about the 40-45 gallon reading.

7. When the delivery meter reads 50 gallons, the filler hose is disconnected and the test ressel and its contents weighed and a recording is made of the weight and pressure.

8. The liquid-return hose is connected and the test vessel evacuated of all liquid.

9. A rerun is then made to determine the constancy of the meter.

10. The test vessel is completely evacuated of liquid.

11. A slow rum is made in an effort to determine whether slippage exists in the neter.

12. The specific gravity of the product being measured is determined by precooling a sample with dry ice well below its boiling point and then taking a hydrometer reading at several different temperatures as the sample warms up. An average of these specific gravity readings is taken as the specific gravity of the product at the temperature which is the arerage of the respective readings.

13. Througl the use of tables, the specific gravity at the actual temperature of the ploduct bcing measured is computed. and from this figure the gallons per pound are detcrmined through the medium of a conversion table.

14. The calculated capacity determined from the weight hased on the specific gravity is compared witl the actual meter reading of 50 gallons, and the meter errol, if any, is obtained.

15. Necessary meter adjustments and subsequent test runs are made until the meter is either brought within tolerance, sealed, or is rejected.

The State of California uses the volumetric method. (See fig. 9.) We use a 70 -gallon test vessel, equipped with a reflex gauge glass calibrated in $1 / 10$ and $1 / 20$ gallon subdivisions from 69.5 gallons to 71.5 gallons. The test vessel is also equipped with thermometers, pressure gauges, a bleeder line to determine when it is empty (and which is also utilized in cooling the gauge glass), pump, an explosion-proof electric motor, necessary hoses, fittings, adapter's, and electrical connections. 


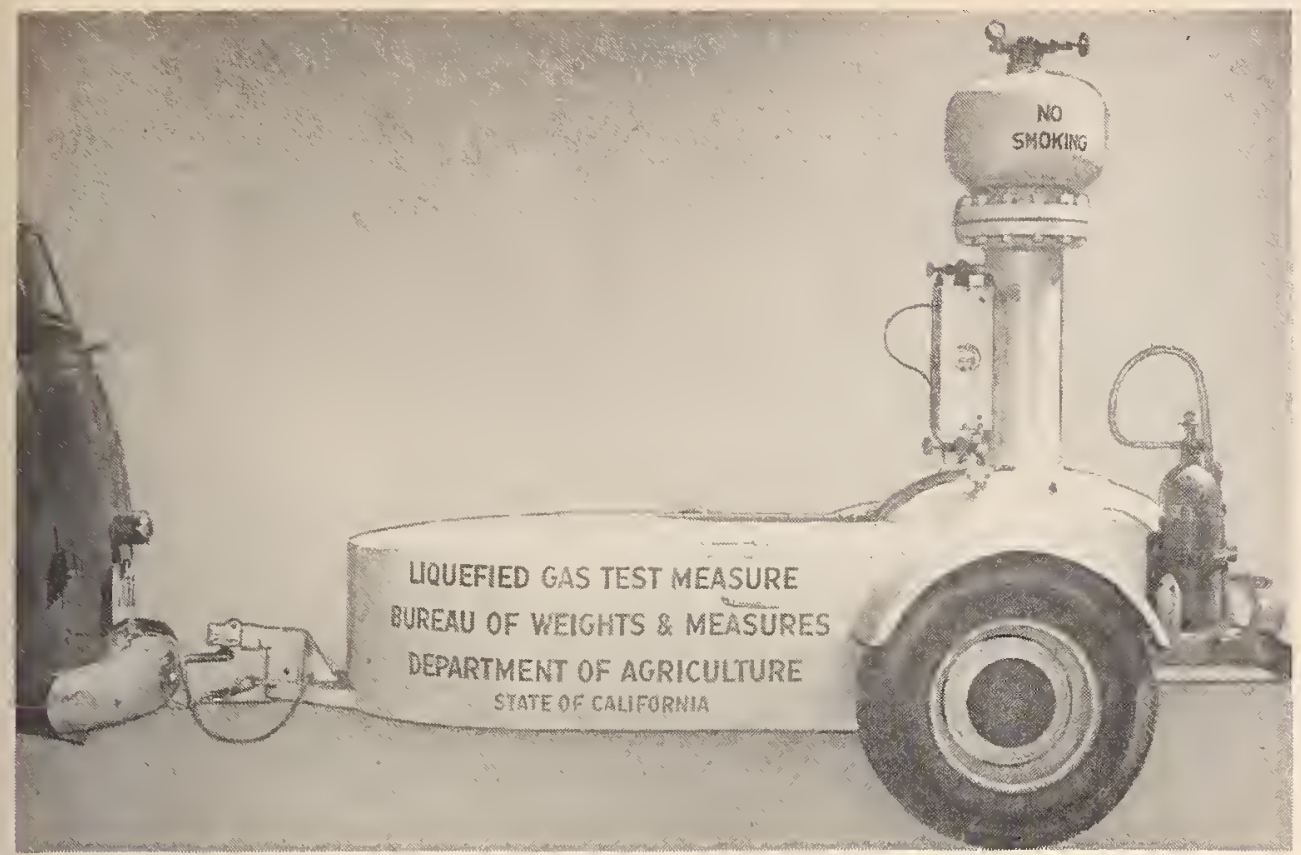

Figure 9. Volumetric-type LPG-meter prover-State of California.

This ressel is mounted on a two-wheel trailer and is built to withstand a working pressure of 250 pounds. It is equipped with all of the required safety devices including two $\mathrm{CO}_{2}$ fire extinguishers. It weighs 2,300 pounds and cost apploximately $\$ 2,200$.

To make a test the trailer brakes are set and the wheels are blocked. The meter that is to be inspected is connected to the test vessel through the medium of the regular dispensing hose and fittings. The vapor spaces of the test vessel and the dispensing vessel are comnected by a vapor return hose and the test vessel pump-back hose is connected to the filler valve of the dispensing vessel whether it be a stationary tank or a vehicle tank. The electrical connection is then plugged into an adequate electric supply. We can use either 110 or 220 volts, a-c.

Before starting the actual test, the metering equipment that is to be inspected should be checked as outlined above iu our discussion of the gravimetric method. 'The actual test is conducted as follows:

1. Seventy gallons of fuel are pumped into the test vessel at the normal rate of flow permitted by the installation.

2. The test vessel is immediately emptied by means of its pump, after which all valves are closed except vapor-returu valves. We have by this procedure equalized the temperature and pressure of the supply vessel and our test measure. The fact as to whether or not the test ressel is emptied of liquid is determined by means of the bleeder valve located in the bottom of the vessel. If the weatler is hot, the gauge glass may be cooled by spraying it with LPG from the bleeder valve during the pumping-back process.

3. The test vessel is then refilled at the same late as before, the rate of fill, vapor pressure, and temperature recorded, and any rariances noted.

4. When the test vessel indicates 70 gallons the filling is stopped, all valves are closed, and the fuel allowed to settle until boiling in the gauge slass ceases. The gauge-glass reading and meter reading are compared and the difference plus or minus is recorded.

5. The test vessel is immediately emptierl. Care should be taken that the filler valve is not accidentally opened during the pumping-back period, that there is no carry-over of liquid through the vapor line, and that upon completion of the pumping-back the test vessel is completely evacuated of liquid. 
6. 'The test ressel is again refilled to 70 gallons in the same manner as noted above except that the rate of flow is one-third of the previous nolmal rate, but is not less than 7 gallons per minute. Results are recorded as before.

7. If the difference between the first and second run does not exeeed 3 cubic inches per indicated gallon (about $9 \frac{1}{2}$ tenths in 70 gallons) the meter is adjusted and additional test luns and adjustments are made until the meter meets State tolerances at normal operating speed. At this time all adjustments are sealed and the metel certified for use.

8. If the difference is greater than 3 cubie inches per indicated gallon, the meter is adjudged unfit for continned operation and the operator is given a 30-ray notice to repair or replace the equipment. If this is not complied with, we have authority under the laws of the State of California to confiscate the (levice.

9. During this test, and usually on the last pump-out, the back-pressure check value is tested by closing the vapor ralve and leaving the fill-ralve open while the test ressel is being emptied. If the meter starts moving before a 10-pound pressure drop is noted, the spring pressure in the back pressure valve is inereased or notice is given to repair or replace the valve. (See fig. 10.)

The result of a test should be noted immediately upon completion of a test run, because if a delay in noting results occur's, the probable change of temperature will affect the accuracy of your findings. The results of each test are recorded in duplicate on individual sheets. (See fig. 11.) These in turn tie into a master sheet which is given a file or test number and which remains the same for all subsequent tests of that particular dealer as long as he may stay in business. (See fig. 12.) In order to collect data, the following information is recorded on the master sheet: Date; location of plant; location of main office; county; name of owner; source of supply; is both butane and propane handled; is there a bulk plant, and if so, the size of storage and the Industrial Accident Commission inspection numbers; is there a bulk meter; is there an automotive service station, and if so, what make and how many meters; is the fuel priced; do the meters have State of California motor vehicle fuel pump license tags; their make,

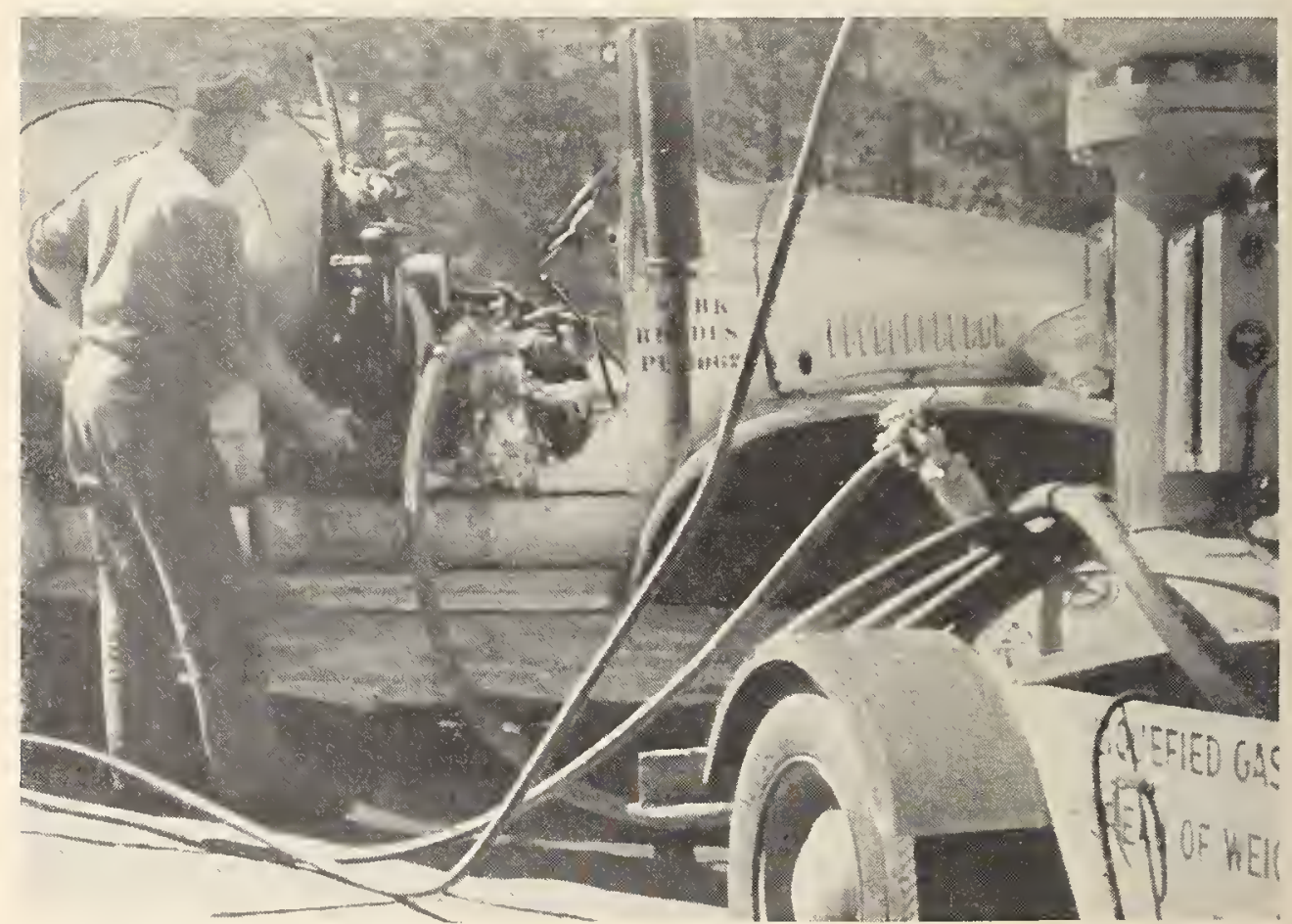

FIgure 10. Testing a truek meter with State of California prover. 


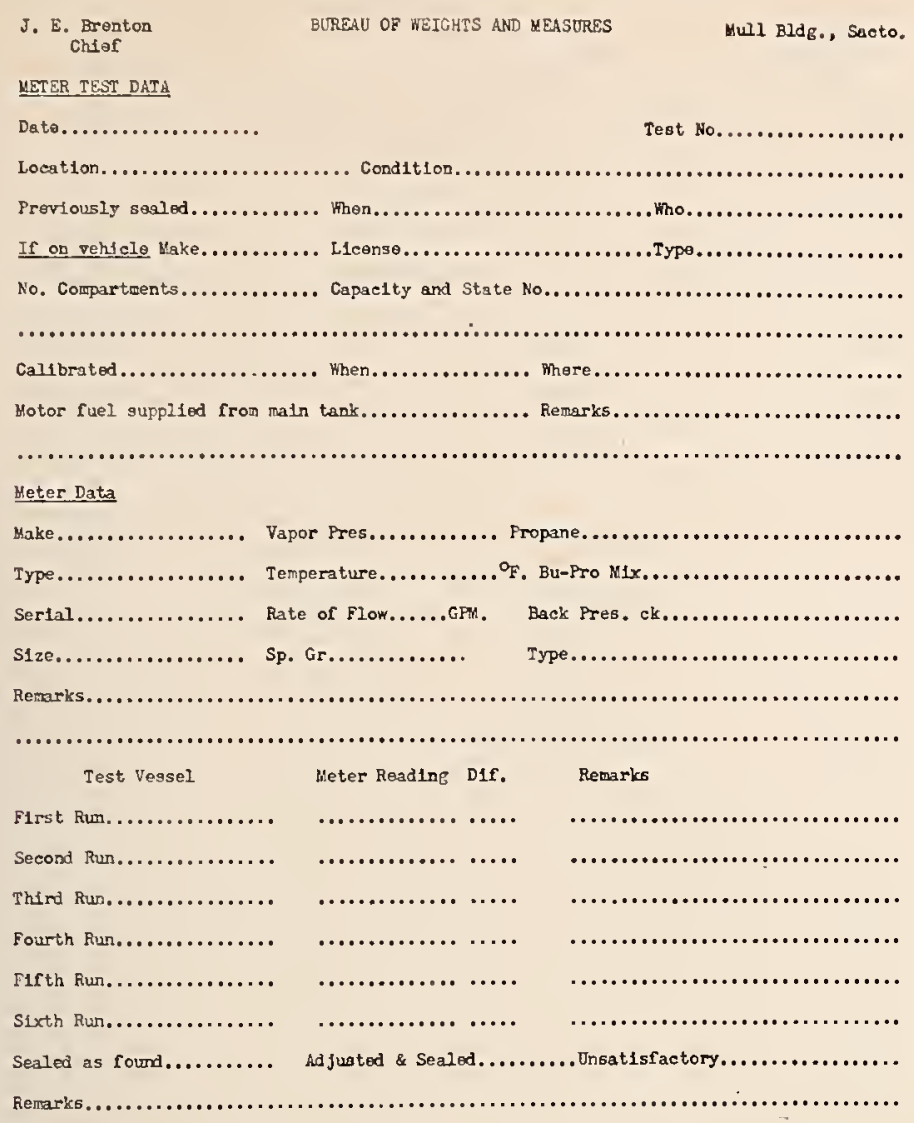

Lquef 1od Petroleuse Gas Teohniolan

Figure 11. "Individual" reeord sheet for LPG-meter tests-State of Califormia.

types, and capacities; if trucks use LPG fuel, do they have a separate tank, or do they draw from the main tank; is there a bottle-fill plant, and if so, is weight, volume, or guess work used to measure the product; is it manual or automatic; the number of scales and when last sealed; and how many motor vehicles are used in connection with the delivery of LPG.

A complete summary of all tests made at this particular time are recorded at the bottom of the page. This includes devices sealed as found, the number adjusted and sealed, and the number found unsatisfactory. There is also a space for the name of the County weights and measures official, providing one participates in the inspection.

The individual test sheets give the following information: Date of test; condition of equipment; was it previously sealed; if so, when and by whom; if on a vehicle, the make, license, type, number of compartments, capacity, the State inspection number; was it calibrated; if so, when and where; is the motor fuel supplied from the main tank; the make of the meter, type, serial number, size; vapor pressure; temperature of the liquid; rate of flow; specific gravity if such is desired; the product that is being measured; is there an acceptable back-pressure check valve installed; type of valve; the result of the individual test showing: Sealed as found?, Adjusted and sealed?, Unsatisfactory, why? 


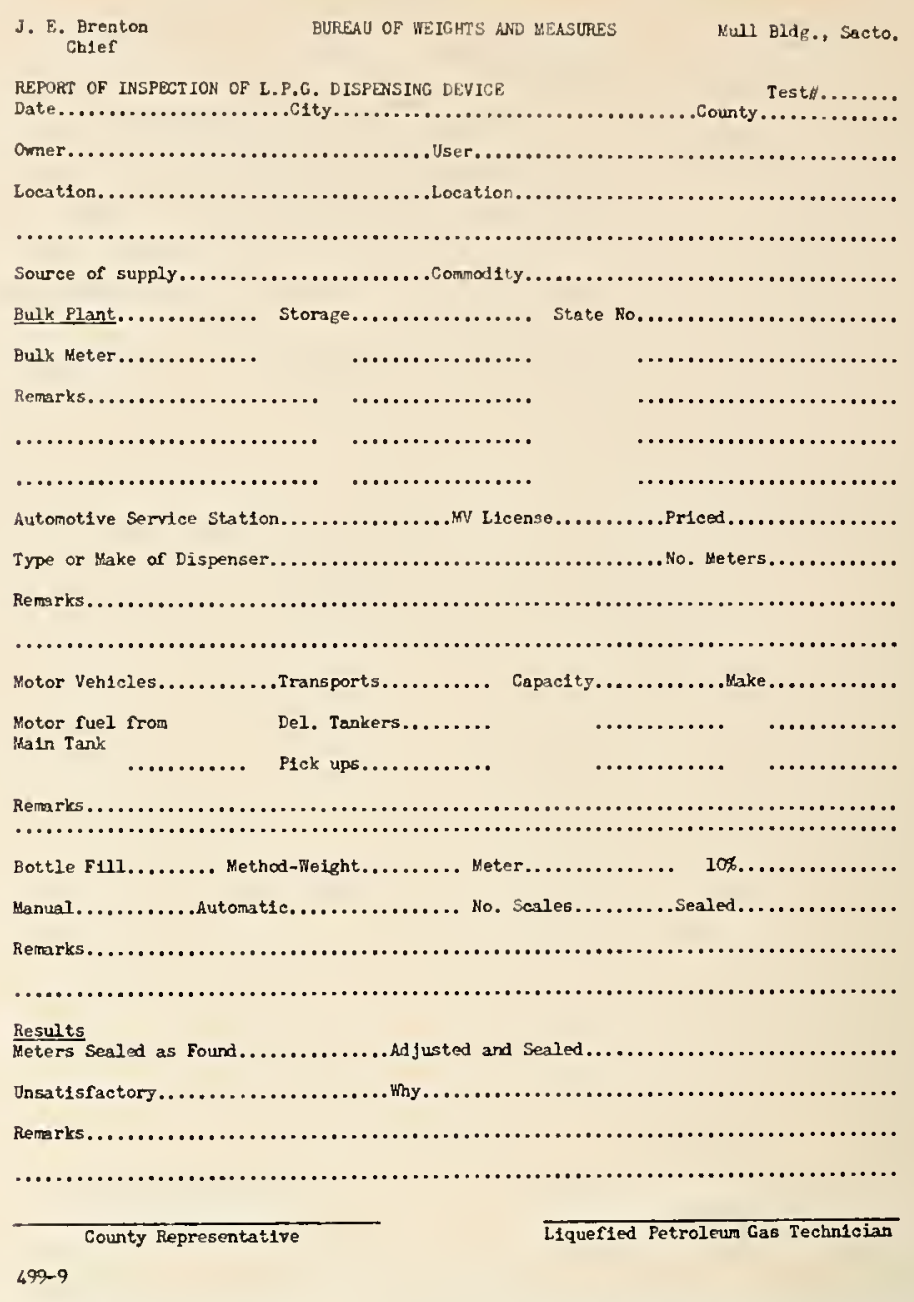

Figure 12. "Master" reeord sheet for LPG-meter tests-State of California.

We prefer the volumetric method because it parallels the delivery as is practiced in an actual sale to a consumer. 'This method of inspection discloses errors of measurement due to rate of flow, leaky diaphragms, delivery of liquid through vapor connections, faulty installation, dirty screens, and sticking meters. It is simpler, considerably faster, and does not require the rather extensive mathematical calculations that are necessary in connection with the gravimetric method.

In addition to the above, the equipment used in the rolumetric method is more fool-proof and rugged than that used in connection with the gravimetric method. For example, in using the gravimetric method, a vapor-return line is not nsed, although in actual commerical practice a vapor return line is oftentimes used; if the dispensing equipment is not in excellent condition it is oftentimes impossible to fill the test vessel, meaning that the dispensing equipment gradually slows down and finally stops during which slow-down excessive slippage occur's, a slippage that would not be existent in a normal delivery. This is particularly true if the weather is warm and the product being measmred is propane. 
We also prefer the volumetric metliod because we do not have to determine the specific gravity of each respective sample being measured; in fact, we do not have to consider the specific gravity of the product at all. Also, from the standpoint of time, we believe that the rolumetric metliod is at least three times as fast as the gravimetric and from the point of accuracy it fulfills all practical field requirements.

This volumetric method is also preferred because utilizing this method, installations either with or' without vapor return lines may be tested, while in using the gravimetric method, a vapor return line is never used during the reights and measures inspection. For example, if an installation that does not have a vapor return line is being inspected utilizing the volumetric method, all that is necessary is to record the vapor pressure at the beginning and completion of the filling and compute the vapor which has been compressed back into a liquid by displacement, and to allow for additional vapor compressed into the vapor space at the liigher finishing pressure.

In order that there would be definite provisions concerning container's, vehicle tanks, and weighing and measuring devices used in connection with the storage and sale of liquefied petroleun gas, a series of provisions applicable to LPG were promulgated and are now contained in Article 16, Subchapter 4, Chapter 8, Title 4, California Administrative Code. Because our time is limited, we shall only discuss those portions of the Code which we believe to be of universal interest:

Sections 3410 to 3413 define certain tanks and containers commonly used in the industry. Sertion 3414 permits the sale of liquefied petrolem gas by weight. Section 3415 permits the sale of liquefied petroleum gas by liquid rolume, either through an accepted meter or by the use of a certified vessel. Section $3 \pm 16$ defines the word "container."

Second 3417 sets up three methods of sale for LPG, namely, by weight expressed in avoirclupois pounds; by liquid volume expressed in U. S. gallons; and by vapor volume expressed in cubic feet. The meaning of cubic feet under various conditions is explained. We do not recognize nor will we permit the sale of LPG in "Butane Units," "Happy Heating Hours," and other catchy phrases which have absolutely no legal basis of measurement from the standpoint of a weights and measures official.

Section 3418 establishes and mifies the data required to be stamped on LPG bottles. Section 3419 requires that all justallations of LPG equipment be inspected for safety by the Division of Industrial Safety, Department of Industrial Relations, State of California, or other autlorized commission, before being clecked for accuracy by a weights and measures official. Section 3420 eliminates the use of the column gauge glass as a means of measuring the volume of LPG for the purpose of sale. Section 3421 prevents fraudulent construction.

Section 3422 requires the certified capacity to be plainly marked on transport trucks. Section 3423 sets forth instructions for the installation of dip pipes (outage gauges) on various types of containel's when such container is used as a measure. Section 3424 requires that all tauk trucks when used as a measure be certified as to capacity.

Section 3425 requires that a meter be accessible and easy to read. Section 3426 prevents the diversion of LPG after metering unless the fact of such diversion is plainly discernible. Section 3427 requires that the indicating element of all meters be in good working order and readily returnable to zero. Section 3428 requires that all meters be provided with an acceptable means of vapor elimination. Section 3429 sets up rules for the testing of LPG meters which include constancy of delivery, testing drafts and tolerances.

Section 3430 establishes tolelances for the inspection and reinspection of vehicle tanks which are being used as a measure. Section 3431 does not permit the use of a liquid meter for the purpose of sale when the LPG is being transferred by the pressure-differential system unless the vapor being returned is also 
measured through an approved vapor meter. Section 3422 prohibits the use of artificial heat to expand LPG for the purpose of sale.

We have tested approximately 2,000 meter's used for measuring the liquid volume of LPG. Of this number we have been able to seal about 5 percent "without correction." Of the remainder approximately 5 percent were delivering short volume while the rest were all delivering in excess, some as high as 25 percent over the indicated delivery. We believe that these figures alone justify the efforts of weights and measures officials throughout the United States to secure adequate testing standards to be used for the purpose of inspecting the accuracy of LPG devices being operated under their respective jurisdictions.

(During the presentation of the foregoing papei numerous slides were shown. These were prepared from photographs of actual installations, and were described briefly by Mr. D. C. Perkins, Measuring Technician, LPG, California State Burean of Weights and Measures.)

\section{REMARKS OF NALIS BERRYMAN, SUPERVISOR, WEIGHTS AND MEASURES} DIVISION, STATE OF FLORIDA

About 3 years ago several dealers in LPG in Florida asked us if we would test their liquid metering systems for accuracy of delivery. We told them we had no equipment for this work, but would try to design and build one.

We knew our equipment would have to be portable to test the complete metering system. We did not think much would be gained by having the meter alone sent to Tallahassee. We searched the literature for information on portable systems for testing LPG meters. About all we found were several articles by Mr. Charles Frller, Sealer of Los Angeles County, California. His articles rere of considerable help. He described two systems, the volumetric and the gravimetric. In the actual planning of a system we found there were many details, both practical and theoretical, that we had to work out. We believed at that time, and we are all the more convinced now, that the gravimetric system is theoretically the best. We believe there are more unknown variables in the volumetric system than the gravimetric. However, at that time we were pushed for time and money, and we ran into several practical difficulties when we considered the gravimetric system. We could not find a practical way of determining the specific gravity of the LPG in the field or locate a weighing device that was both portable and accurate. Mr. Fuller used dry ice to cool his LPG when taking the gravity. Dry ice was not available in Florida except in several large cities. We found the regular portable platform scale inaccurate, and unreliable, after bumping over the highways on a trailer. Since then we have located a pressure hydrometer jar and hychometer sold by the Refinery Supply Company, of Tulsa, Oklahoma, and $M_{1}$. H. L. Shankle, of the State of North Carolina, has designed and had built a proper portable weighing scale. Mr. Shankle and I collaborated over the telephone several times, and he rather recently built a gravimetric system using the pressure hydrometer jar, which you will have described later by a gentleman from the Weights and Measure Division of North Carolina.

To make a long story short, we designed and had built, about 3 years ago, equipment for calibrating LPG meters by the volumetric principle. "The tank looks something like a mushroom upside down. The bottom part is made of two 4-foot-diameter, dished tank heads welded 
together with their concave sides facing one another. A 12-inch round hole was cut in the center of one tank head, and a cylinder 12 inches in diameter and 20 inches long attached, and on top of this cylinder was attached another vessel made by welding together, concare sides facing, two 20 -inch-diameter, dished tank heads. To the outsicle of the cylinder, or neck, of our volumetric measure is attached a heary glass-gauge tube with scale. The gauge tube is partially insulated. The ressel attached to the top of the neck serves as an accumulator chamber for rapor. Attached to the top of this accumulator chamber are a safety valve, a pressure gauge, and a pressure-returnline comnection. The meter-delivery-line connection is on the top surface of the large bottom chamber. The valve and connection for emptying the measure are at the very bottom. Also at the bottom is a derice for determining if the measure contains any liquid. 'The bottom chamber is also equipped with a thermometer' well." (See fig. 13.)

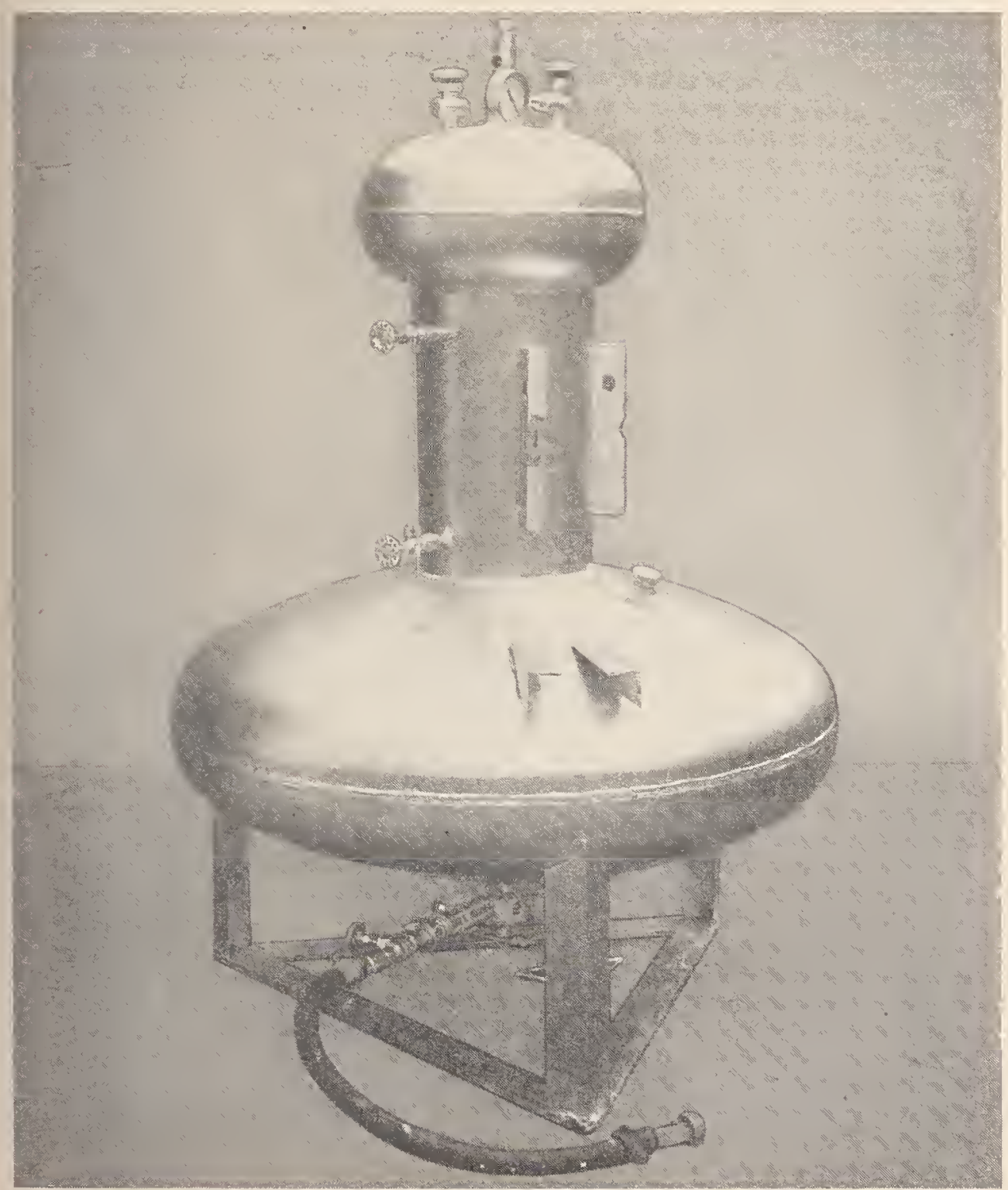

FIGURE 13. Volumetric-typo LPG-meter prover-State of Florida. 
A pump for emptying the measure is also part of the equipment. Much could be said about the pump. The measure was designed to hold 100 gallons to center of neck; it held 103 gallons to the center.

We calibrated the measure with water, using our 50-gallon Bureau of Standards certified measure. The vapor-return-line fitting was removed from the vapor accumulator tank at the top of the unit and the water rum in by a short hose from the standard measure. IVe determined the volume the new measure would hold at a definite temperature and at a definite pressure. Points on the gauge scale were determined for 100 gallons to 106 gallons at 1-gallon intervals at atmospheric pressure. The vapor return fitting was then replaced, hose connection made, and air pumped in. The volume was then determined at increasing increments of 10 pounds per square inch pressure. The safe limit of working pressure of the unit is 200 pounds per square inch. WVe found the elastic limit of the measure for all practical purposes to be at 80 pounds per square inch. I have included here in this paper a complete copy of the calibration sheets.

Before checking a meter we first fill the measure with the LPG and then pump back to the tank, completely emptying the measure of all liquid, but keeping the vapor pressure. When making a check run we duplicate as closely as possible an actual delivery by the metering system to the customer's tank. We found very few dealers using a vapor return line from the customer's tank to his storage or truck tank. We therefore did not use our vapor return connection in many cases. When we did, we knew we were introducing a probable source of error, even though the metering system was being used in that manner. We discouraged the use of vapor return lines. Every now and then we would rum across a pump on a dealer's tank truck that would not pump against the pressure developed in our unit when nearly filled with liquid to the 103 gallon mark. Generally a little work on the pump corrected this difficulty. LPG high in propane content, due to its high vapor pressure, caused the most trouble.

After the delivery had been made we would read the liquid level gauge, thermometer and the pressure gauge and determine the volume by the unit calibration sheet.

We can generally check within $1 / 2$ percent on successive runs with the same meter, but we realize we have some variables that may be causing an error. There is the possible difference in temperature of the LPG when in the measuring chamber of the meter compared to the temperature of the LPG when in our measure. We can easily determine the temperature of the liquid when it is in our measure by a thermometer in the thermometer well, but we cannot determine the temperature of the liquid in the dealer's meter. 'The temperatures should be the same, or if they are different, we should know what they are and make a correction.

We doubt that LPG metering systems can ever be checked to as close a tolerance as fuel oil, kerosene, and gasoline metering systems. At present we are using an unofficial tolerance of 2 percent. We believe this tolerance could be cut considerably if a properly constructed gravimetric prover were used. We think our volumetric unit has been of practical value in adjusting LPG liquid meters in the field and we will probably continue to use it until we have the money 


\begin{tabular}{|c|c|}
\hline Water, gallons, at $70^{\circ} \mathrm{F}$ & $\begin{array}{c}\text { Inches on scale } \\
\text { at atmospheric } \\
\text { pressure }\end{array}$ \\
\hline $100 \ldots 1$ & \\
$101 \ldots 2$ & \\
$102 \ldots 5$ \\
$104 \ldots 5$ \\
$105 \ldots$ \\
\hline \hline
\end{tabular}

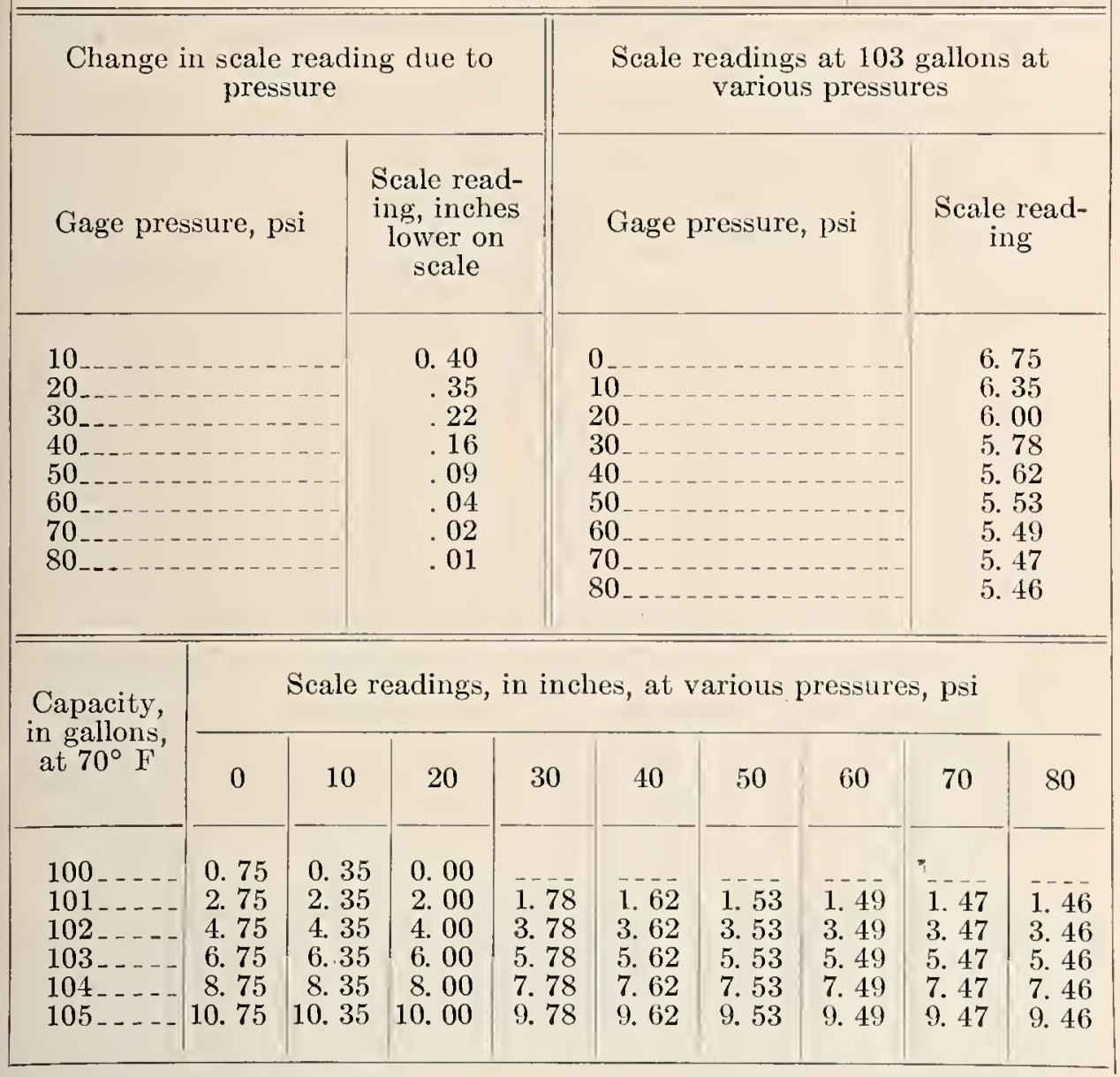

and time to design and build a gravimetric unit. Certainly on paper, the gravimetric unit would seem to be the best idea.

(At this point, Mr. J. E. Brenton, Vice President of the Conference, assumed the Chair.)

\section{REMARKS OF E. W. HESSEE, SENIOR CHEMIST, WEIGHTS AND MEASURES DIVISION, STATE OF NORTH CAROLINA}

The increasing growth of the liquefied petroleum gas industry in North Carolina, with an attendant increase in bulk deliveries of the gas by liquid meters, necessitated the design and operation of equipment for testing these meters in order to protect the purchasers of this com- 
modity. North Carolina's answer to this challenge was the LPG liquid meter test unit as illustrated in figures 14 through 18 .

The purpose of this talk is to describe the operation of this test unit, show the method of calculation, point out possible sources of error, and to make some remarks about standard test procedures.

As you will notice from fig. 14, the emphasis is on portability. Most of the testing equipment is incorporated in a well-balanced, sturdy, trailer unit. The more delicate apparatus such as the portable scales, pressure hydrometer jar, and inlet thermometer are carried in the tool box in cases especially constructed to prevent damage in transit. Fittings, adapters, wrenches, and other accessory equipment are also kept in the tool box in a separate compartment. The necessary lengths of hose are carried in the back of the truck. This completed assembly has traveled thousands of miles over all kinds of roads without the slightest damage to any part of the equipment, with which a number of tests have been conducted on many different metering systems.

The nature of the product handled was taken into consideration in the design and construction of this test unit. The tank, valves, fittings, piping, and hose were all selected for high-pressure operation sufficient for propane service, since there are many distributors of propane as well as butane-propane mixtures.

This portable unit makes it possible to perform the test on the premises of the distributor, but before the test unit is set up, a site is selected in accordance with all good safety practices. The equipment is usually set up at a bulk plant or terminal from which the LPG tank trucks make their hauls. An area is selected where sources of ignition are remote, so that, when venting is necessary, fire hazard is kept at a minimum. The trailer is then unhooked from the truck, positioned, and placed on jacks so that it will remain stable throughout the tests (figs. 15 and 18). A ground wire from the trailer is connected to an improvised ground if no permanent ground is convenient. The four retaining clamps are removed from the tank retaining ring, releasing the tank from the trailer floor. At this time, the ground

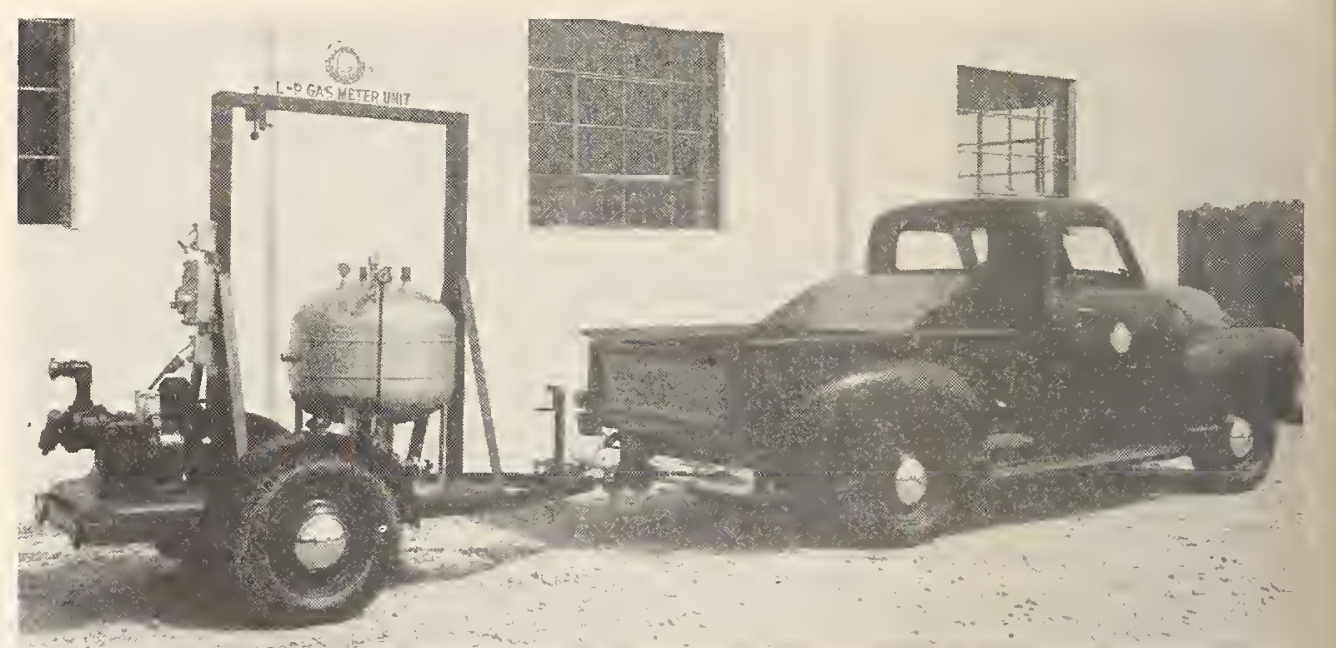

FIGUIE 14. Gravimetric-type LPG-meter prover-State of North Carolina. 
wire from the tank ring to the trailer floor is examined to insure that it is intact. The portable scales are suspended from the supporting bar and universal and adjusted to the level position by simple rotation of the adjusting crank handle (figs. 15 and 16). The suspending jack is connected between the scale and weigh tank. The filler connection with the thermometer in the "T" assembly (figs. 15 and 17) is hooked to the inlet line by means of a quick coupling. The electrical hook-up is made and the motor started to ascertain that the pump is working properly. The pump-back hose (see figs. 15 and 18) is hooked up and the actual testing is ready to begin.

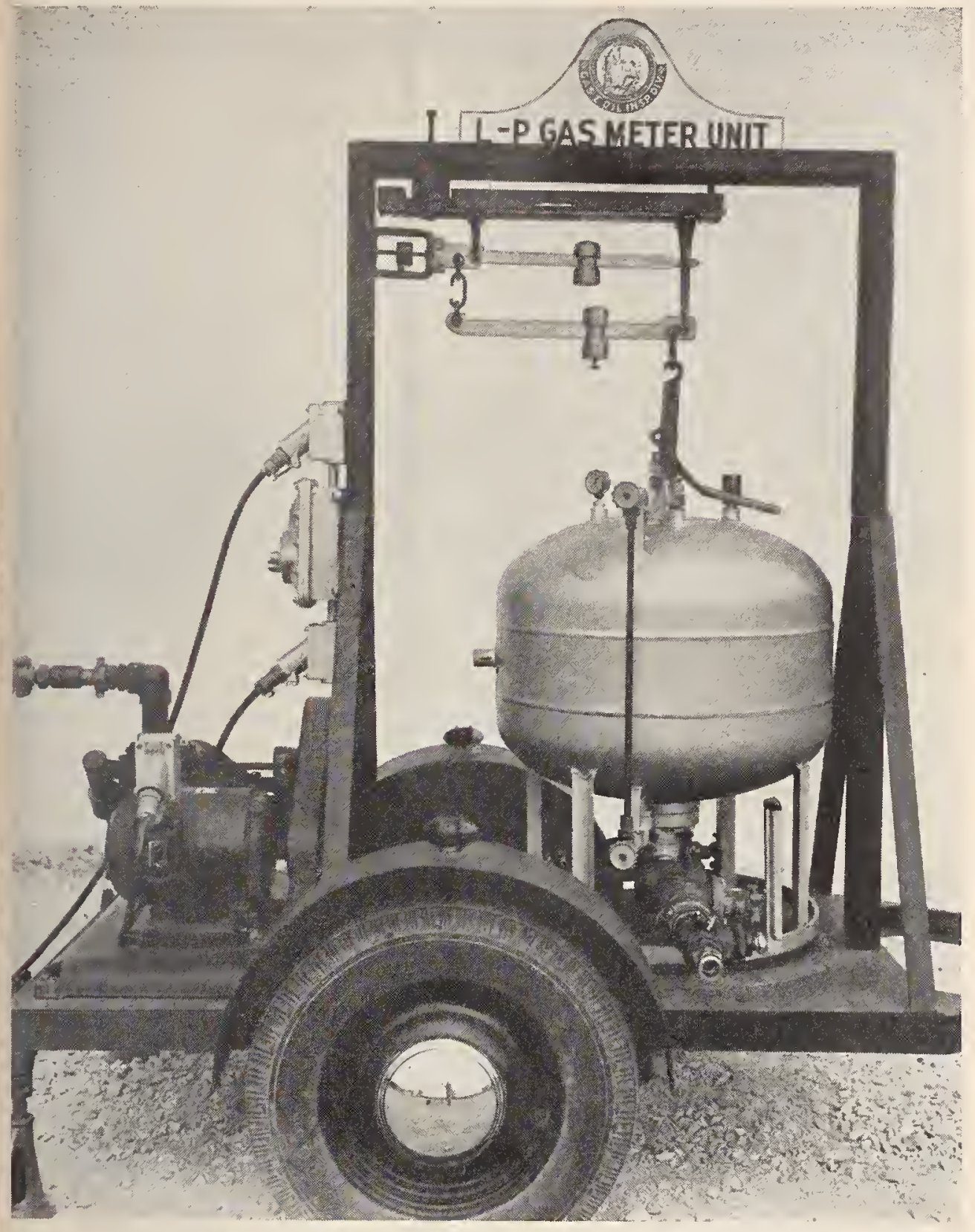

FigURE 15. North Carolina prover in weighing position. 


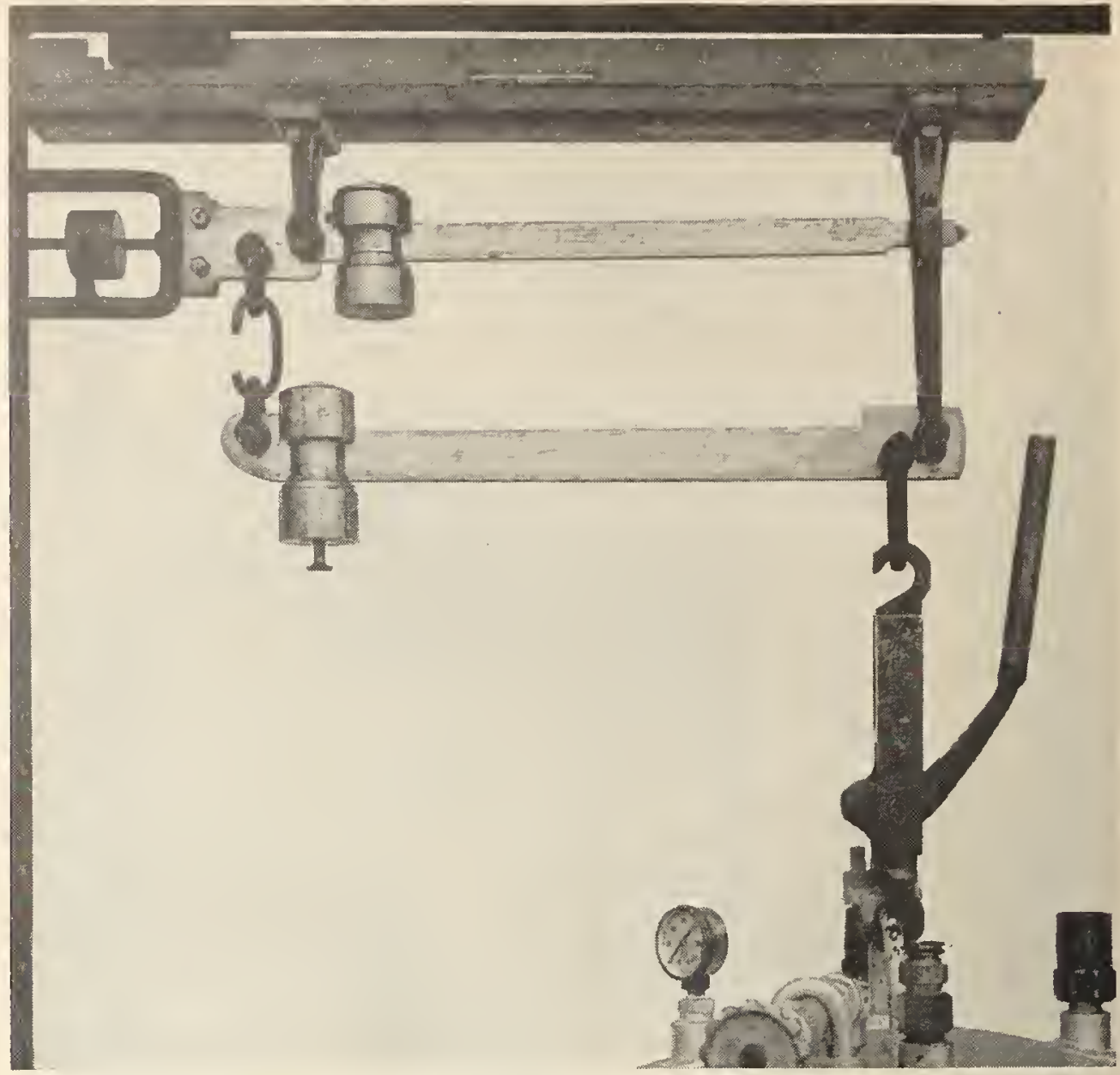

Figure 16. Weighbeam of North Carolina prover.

The tests should determine (a) whether the meter will duplicate, (b) whether the meter is accurate, (c) and whether the back pressure mechanism is set sufficiently high to prevent vaporization in the meter at conditions of test. Before actually making test runs the outlet valve on the tank truck delivery hose is opened with the truck pump not operating. If the back pressure valve is set high enough at the prevailing temperature the liquid will drain from the hose to the backpressure valve without the meter spiming.

Before any gas is pumped from the tank truck into the prover, all comnections and valve positions are reinspected. Then 50 gallons of product are pumped into the prover tank and returned to storage. This serves the purpose of purging the tank, equalizing the temperature, and filling the delivery hose with liquid. If there are no leaks between the meter outlet and the prover we are ready for the first test. The tank is weighed for tare weight. Figure 15 shows the tank in the weighing position. The tank is lowered and the "wet" delivery hose reconnected. Fifty gallons of LPG are then metered into the prover tank. The operating temperature is observed carefully and recorded. When the delivery is completed, hose connections are again disconnected and the gross weight determined. The net 
weight of gas delivered is obtained by a simple subtraction of the tare weight from the gross weight.

The next step is the determination of the specific gravity of the product in order to obtain the weight per gallon of the LPG product at the operating temperature. The pressure hydrometer jar with hydrometer installed (see fig. 17) is conmected to the sampling valve and the jar is filled and purged. The jar is then refilled to a level which freely floats the enclosed hydrometer and the specific gravity determined, as set forth in the procedure from $N . G$. A. A. Standard Methods for determining the specific gravity of volatile hydrocarbon products by means of the hydrometer. The specific gravity is recorded with the temperature indicated by the thermometer in the hydrometer.

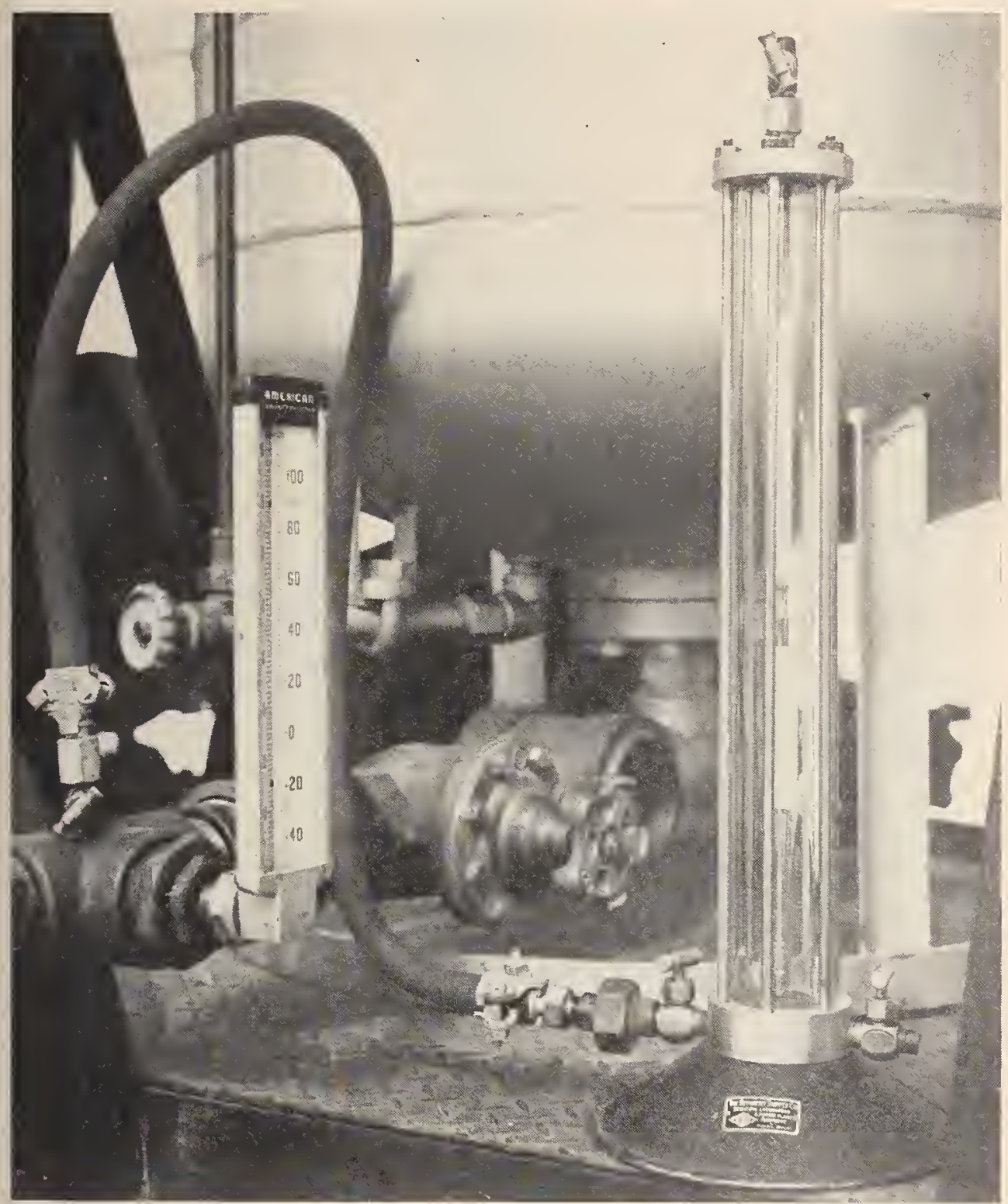

FrgURE 17. Inlet thermoneter, sampling line, and pressure hydrometer jar with luydrometer enelosed-North Carolina prover. 


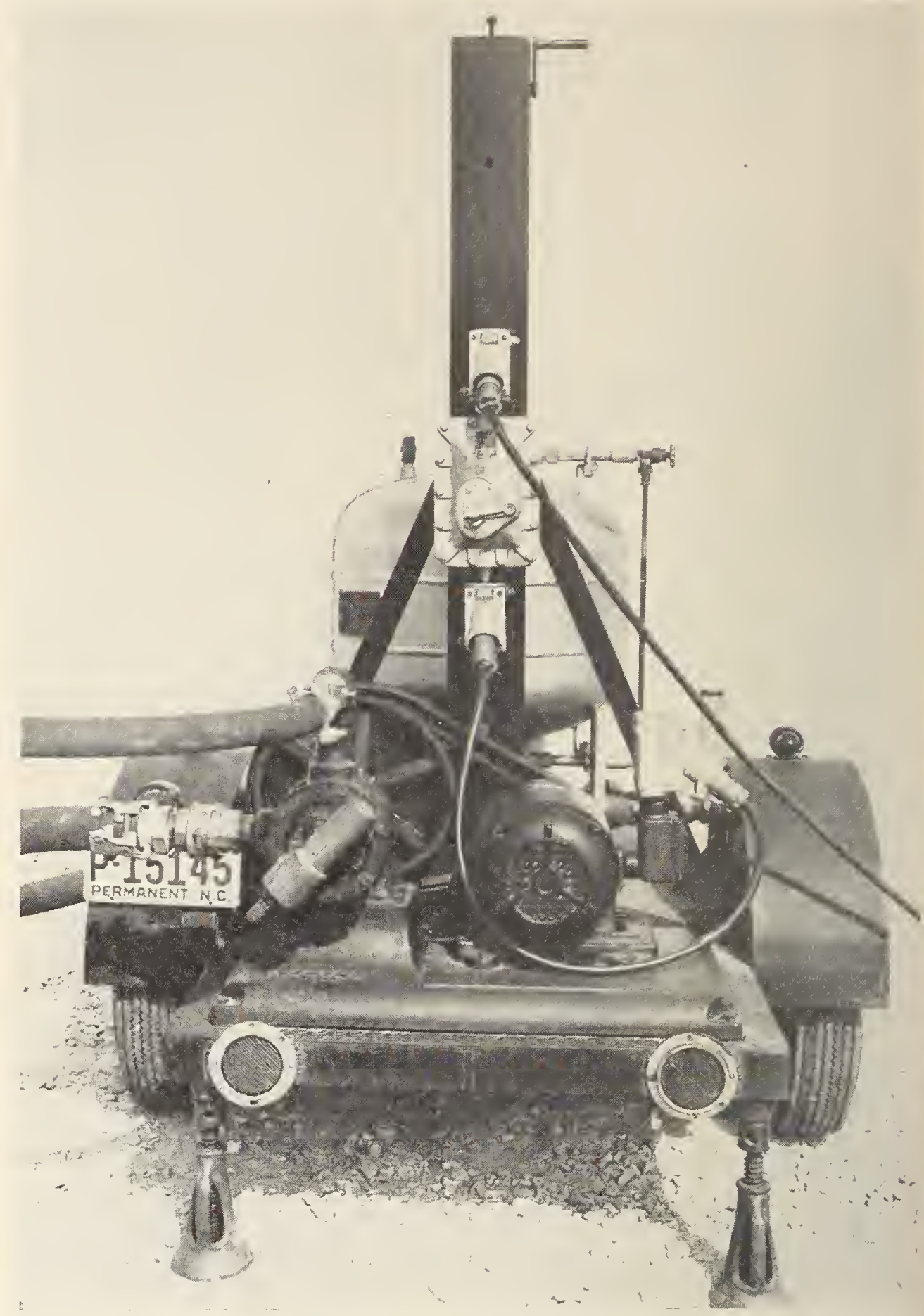

Figure 18. Rear view of North Carolina prover. 
This specific gravity must be corrected to the temperature of delivery by means of N. G. A. A. correction tables. The weight per gallon is obtained by multiplying the corrected specific gravity by the weight per gallon of water at $60^{\circ} \mathrm{F}$. The calculations are then carried out as shomn on the inspection form (fig. 19), and the percent error determined. Sereral such consecutive tests are rum to determine whether or not the meter is duplicating and to show whether the particular system being considered is satisfactory for metering LP gas under different conditions. 'The following precautions must be observed if the test results are to be valid.

1. Inlet temperature.-The inlet temperature as indicated by the inlet thermometel represents the temperature of the liquid passing through the meter. For this reason this thermometer must be as close as possible to the meter being tested. This temperature will nsially level off after a few gallons have flowed through the inlet connection and should be recorded as the delivery temperature. If for any reason the inlet temperature is erratic, the run must be discarded.

2. Weight determinations.-Weight determinations must be made carefully since any error in the net weight wonld show up in results as an apparent meter error. The upper beam (600-pound capacity) on the test scale is the notch-beam type to eliminate possible elrors in positioning.

3. Specific Gravity.-If the test is to be accurate the specific gravity determination must be accurate. For this reason good attention should be paid to details in taking the specific gravity of the sample and care exercised that proper corrections are made to convert this specific gravity to the temperature of delivery.

4. Vapor return.--Vapor return is not used in making deliveries to the prover tank for purposes of test for the following reasons:

a. It must first be determined whether the metel being tested will duplicate, and if vapor return were used, accurate compensation for the vapor returned would be necessary. This is not practical, because the vapor density for the particular LPG mixture under consideration would have to be known and the vapor density under the possible varying conditions of flow would either have to be constant or an accurate average rapor density would have to be used, the determination of which wonld make the accuracy of the test method uncertain. Experience lias also shown that the amount of vapor returned by the same system under the varying conditions of delivery varies widely.

b. In the event that the pump will not deliver 50 gallons into the prover tank at a sustained rate of at least 5 gallons per minute, then it is necessary to limit the delivery accordingly.

5. Initial test.-It is desilable on the initial delivery, and additional deliveries if necessary, to start the test with the prover tank at zero psi gauge pressure. This test will usually indicate whether or not the back pressure valve on the downstream side of the meter is set high enough to maintain the gas in the liquid state as it passes through the meter. If there is no back pressure valve, or if it is set too low, or is inoperative, vapolization will occur in the meter under certain conditions of delivery and metel error will result (see Delivery 1, fig. 19).

To illustrate the test method just explained, a report of an actual inspection has been shown in figure 19. This particular LPG meter system was equipped with a back pressure valve which was merely a spring loaded check valve, and not a differential valve of the diaphragm type. Before the test was started, it was determined that this spring loaded check valve was not set as high as the vapor pressure of the liquid at the prevailing temperature. This was determined by opening the delivery valve to the atmosphere and observing the spinning of the meter. Had the back pressure valve been set to the highest vapor pressure which the product would exert under normal temperatures of operation, the meter would not have registered until the pump was started. Before the first delivery was made, the delivery hose was filled with liquid. Observe that the meter delivered 
Form LFG 101

Name

Address

Truck

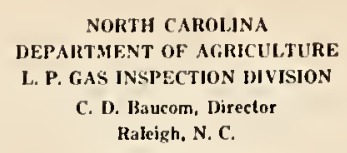

NORTH CAROLJNA

DEPARTMENT OF ARIRICULTURE L. P. GAS INSPECTION DIVISION

C. D. Baucom, Director Raleigh, N. C.

L. I'. Gas Liquid Meters

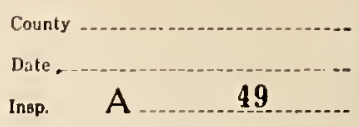

\begin{tabular}{|c|c|c|c|c|}
\hline \multicolumn{2}{|c|}{ Meter } & \multicolumn{2}{|c|}{ Accessories } & Pump \\
\hline Make & Tolalizer Rds 11,493 Gallons & Vaper Eliminutor & None & Make \\
\hline Model & Visibility & Back Pressure Valve & Yes & Model \\
\hline Size $\quad 11 / 4$ inch & Legends & Differential Volve & No & Rated G.P.M. \\
\hline & Wet Hoge & Anel-alsain Nozzle & No & Equipped \\
\hline
\end{tabular}

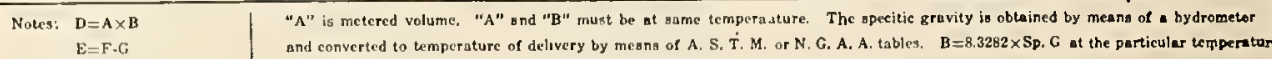
$\mathrm{C}=100[$ (E. D) $\div$ (E) $] \quad$ of delivery.

\begin{tabular}{|c|c|c|c|c|c|c|c|c|c|c|c|c|}
\hline \multirow{2}{*}{$\begin{array}{c}\text { Column } \\
\text { Deliv. } \\
\text { No. }\end{array}$} & \multicolumn{2}{|l|}{ A } & \multicolumn{2}{|l|}{ B } & \multirow{2}{*}{$\begin{array}{c}\text { C } \\
\text { Pereent } \\
\text { Ertor }\end{array}$} & \multirow{2}{*}{$\begin{array}{l}\text { D } \\
\text { Calculated Net } \\
\text { Weight in } \\
\text { Pounds }\end{array}$} & \multirow{2}{*}{$\begin{array}{l}\mathrm{E} \\
\text { Actual Net } \\
\text { Weight in } \\
\text { Pounds }\end{array}$} & \multirow{2}{*}{$\begin{array}{c}\text { F } \\
\text { Gross } \\
\text { Weight in } \\
\text { Pounds }\end{array}$} & \multirow{2}{*}{\begin{tabular}{|c|} 
G \\
Tare \\
Weight in \\
Pounds \\
\end{tabular}} & \multirow{2}{*}{\multicolumn{2}{|c|}{\begin{tabular}{|c|c|} 
H & I \\
Prover & Tank \\
Preasure & (PSIG) \\
Initial & Final \\
\end{tabular}}} & \multirow{2}{*}{\begin{tabular}{|c|} 
J \\
Average \\
Delivery \\
Rece (GPM) \\
\end{tabular}} \\
\hline & $\begin{array}{c}\text { Gellons } \\
\text { Dulivered }\end{array}$ & $\begin{array}{c}\text { Temp. } \\
\cdot \mathbf{F} \\
\end{array}$ & $\begin{array}{c}\text { Deneity } \\
\text { Pounds Per } \\
\text { Gallon } \\
\end{array}$ & $\begin{array}{c}\text { TemD } \\
=F\end{array}$ & & & & & & & & \\
\hline 1 & 36.00 & 60 & 4.589 & 60 & -4.39 & 165.20 & 158.25 & 552.25 & 314.00 & 0 & 60 & \\
\hline 2 & 36.00 & 62 & 4.581 & 62 & -0.10 & 164.92 & 164.75 & 560.75 & 396.00 & 50 & 65 & \\
\hline 3 & 36,10 & 62 & $4.5 \mathrm{\theta} 1$ & 62 & -0.07 & 165.37 & 165.25 & 561.75 & 396.50 & 50 & 20 & \\
\hline 4 & $\$ 5.95$ & 63 & 4.572 & 63 & +0.09 & 164.36 & 164.50 & 561.75 & 397.25 & 55 & ro & \\
\hline 5 & 34.60 & 64 & 4.564 & 64 & \pm 0.06 & 157.91 & 158.00 & 555.25 & 397.25 & 55 & 75 & \\
\hline $6^{-a}$ & 40.20 & 64 & 4.564 & 64 & -1.78 & 183.47 & 180.25 & 578.00 & 397.75 & 55 & 55 & 20 \\
\hline$\pi^{2}$ & 40.40 & 64 & 4.564 & 64 & -1.59 & 184.39 & 181.50 & 579.25 & 397.75 & 55 & 55 & 20 \\
\hline \multicolumn{13}{|c|}{$-2=-1+1=$} \\
\hline 9 & & & & & & & & & & & & \\
\hline \multicolumn{5}{|c|}{ sp.c.@64.0.547,@60.F 0.551} & \multicolumn{4}{|c|}{ Approved....... Condemned ......., Relcased -..-.... } & \multicolumn{4}{|l|}{ Inspector: } \\
\hline
\end{tabular}

Remarks: Produst: Butane-Propane Mixture

Produst: Butane-Propane Mixture
Peliveries betwean 20 to 5 , wallonb per minute.

- Deliveries 6 and 7 made with vepor return.

FIGURE 19. LPG-meter inspeetion form-State of North Carolina.

short measure on the first delivery because of partial vaporization of liquid in the meter caused by insufficient back pressure. In deliveries 2 through 5 , inclusive, the meter duplicated and gave accurate measure as shown by the results; the gas in the prover tank provided the back pressure necessary to maintain a liquid state in the meter.

The gallons delivered were less than 50 gallons because the pump would not deliver that quantity and maintain a flow rate of at least 5 gallons per minute. The quantities delivered were not identically the same in each delivery because the operator could not shut off flow at the same meter reading each time. In such cases, when the test delivery can not be carried to at least 50 gallons without vapor return becanse of the pump, it has been necessary to do the best that is possible under the circumstances rather than run no test at all.

Deliveries 6 and 7 were made with vapor return to show that the net delivery is less when vapor return is used. Under the many different conditions of delivery the amount of vapor returned would vary considerably. No attempt is made to set the liquid meter so that it will compensate for the rapor returned to the delivery tank.

The results of this actual test show that this system would not be satisfactory and accurate under all conditions of operation.

Summary. - An apparatus for testing LPG liquid meters has been described, and a tentative test procedure has been set forth and illustrated. The speaker, in concluding, would like to point out the need for comparing the various methods of testing LP gas liquid meters and the subsequent development of standard testing procedures. 
REMARKS OF JOHN POMMERSHEIM, ENGINEERING DEPARTMENT, PITTSBURGH EQUITABLE METER DIVISION OF ROCKWELL MANUFACTURING COMPANY

The development of LPG metering has been characterized more by a process of revision and adaptation of the existing fluid meter than by any new development intended solely for the measurement of LPG. Up to the present time, this redesign and adaptation has proved quite effective and seems to be meeting the demands of the industry in regards to accuracy, performance, and safety. Further developments will, no doubt, take place to meet increased demands as time goes on.

To appreciate more fully the problems attending the measurement of LPG, let us look at some of the characteristics which have necessitated the redesign of the present ordinary fluid meter.

Pressure.-LPG systems are called upon to withstand pressures much higher than those handling gasoline and fuel oils. This requirement has necessitated the use of a meter case able to withstand a working pressure of $250 \mathrm{psi}$ and which, to provide a suitable factor of safety, should be hydrostatically tested at 500 psi. As an added precaution, case materials are selected on the basis of their ability to withstand shattering under pressures of five times their working pressure or 1,250 psi. Internally we find this requirement met with strengthened parts, either through the use of redesigned parts or new materials, so that any deformation and misaligmment of moving parts due to these high pressures can be held to a minimum.

Viscosity.-The efficiency of the measuring element in any positivedisplacement meter is directly related to its fit in the measuring chamber so that we are interested in obtaining the least amount of slippage (unregistered liquid) consistent with, practically speaking, free operation of these moving parts. It is a recognized fact that such slippage increases with decreased viscosity so that the tolerances of the fits between the measuring element and its chamber have had to be reduced to insure accuracy in measuring these low-viscosity fuels. Such close tolerances, in turn, have also necessitated the use of different materials with improved bearing qualities.

Lubricating Qualities.-The lubricating qualities of LPG are characterized by their complete absence. They act rather as solvents and prohibit the use of lubricants on any moving parts. Such materials as are used for bearings must be selected with this requirement in mind. 'This solvent characteristic further limits us in our choice of materials for gaskets. We have found that the asbestos-rubber and Buna-N types of synthetic materials are most satisfactory for this service. At parts in the meter where no swelling at all is permissible, such as in the piston packing in the piston-type meter, we are restricted to the use of specially treated leather.

Corrosiveness.-Generally speaking, LPG fuels have no corrosive properties; however, some produced by a cracking operation and not thoroughly cleaned may give trouble in this respect. Ordinarily we are not restricted in our choice of metals because of any colrosive properties of these fuels.

Low Boiling Point.-This characteristic of the LPG fuels has been the greatest obstacle to the accurate metering of these liquids. Inasmuch as the positive-displacement meter makes no distinction between 
vapor and liquid, it will register both, making it necessary that only liquid enter the meter. In the measurement of gasoline and oils with higher boiling points, the elimination of vapor has been quite successfully accomplished by means of a float-actuated valve either built into the meter or contained in a separate unit installed ahead of the meter. The high pressure involved in LPG measurement, however, oftentimes crushed this float and rendered this type of construction impractical. The solution of the vapor problem in the closed LPG metering system lies more in the prevention of vaporization through maintenance of sufficient back pressure, than in its elimination. Both measures, however, need to be taken, and are carried out by means of appropriate accessory equipment.

This accessory equipment, whose use is an absolute necessity for accurate LPG metering, brings up another point for consideration, namely, the pressure drop required by the meter, or the meter and strainer, to deliver its rated capacity. The amount of pressure drop required by any fluid meter to deliver its rated capacity is important; however, in the LPG system with its many restrictions in the pump outlet line, together with the necessity of maintaining sufficient back pressure to collapse any vapor, this question of pressure drop becomes doubly important. It is essential that the LPG meter operate with as low a pressure drop as possible in order that the pressure requirements of the pump be kept to a minimum.

In regard to the problem of meter testing, special recognition must be given to the contributions by the Sealers of Weights and Measures of the State of California. Little can be added at the present time to the information on methods of meter proving which they have developed.

Optimum proving practice requires that a meter be proved under the same operating conditions and with the same liquid as will be encountered in actual service. Due to the many demands made upon the meter manufacturer for meter's to measure various liquids, they have found it impractical, if not impossible, to follow this practice throughout. This has been particularly true in the production of LPG meters. Because of the difficulties attending the use of liquid propane or butane as a proving medium, manufacturers are generally restricted to the use of some non-hazardous and stable proving fluid; however, in order to insure that these meters are properly calibrated for their respective services, some correlation has had to be set up between the lesults obtained with the proving fluid and those called for under service conditions. In order to establish this correlation, and as a continued check on meter performance, the manufacturers have availed themselves of the facilities and services of various cooperative Sealers of Weights and Measures and Liquefied Petroleum Gas agencies. Investigations are currently being made into the possibility of formulating the meter performance (accuracy and pressure drop) so that it inight be possible to predict the performance of any one type of meter for any fluid when its performance is known for one of them. Such an investigation requires considerable work and study so that it will probably be some tiune before any decision regarding the practicability of such a procedure will be made.

A survey of LPG meter-proving practice used throughout the country reveals the use of three proving methods-gravimetric, volumetric, 
and water displacement. As stated previously, most of the development of these methods has been made by the weights and measures persomnel and has been reported upon by them so that no attempt will be made to elaborate upon them. Each of these methods, if properly carried out by trained persommel, will give the required accuracy necessary for meter proving.

\section{DISCUSSION ON THE FOUR PRECEDING PAPERS}

Mr. Hessee. I wish to ask Mr. Brenton how, in the use of the vol. umetric prover, he makes temperature corrections to correct the volume in the prover to the temperature of the delivery which passed through the meter.

The Chairman. Mr. Perkins is the operator of our test unit in California, and I shall refer that question to him.

Mr. Perkins. We do not attempt to make any temperature correction. We make a very rapid rum, and in that way we get our temperatures very nearly equal. I have found by actual check that there is usually less than one degree difference between the temperature in the meter and in the test vessel. If the liquid remains even for only a few minutes in the test measure on a hot day we discard that run.

Mr. Hessee. I think that in all fairness to the manufacturers, a standard test procedure should be developed, because the meter's which we are attempting to test will probably repeat within a higher degree of accuracy than the accuracy which we can claim for the test method itself.

The coefficient of expansion of propane is roughly 0.15 percent per degree Fahrenheit. It is obvious that the liquid is at some temperature when it goes through the meter being tested; if that temperature happens to be $60^{\circ} \mathrm{F}$ and the temperature of the liquid in the prover is $64^{\circ} \mathrm{F}$, it is again obvious that there is going to be an expansion of 0.6 percent.

This temperature variable is involved in both the volumetric and gravimetric methods of proving. 'The gravimetric method is based on weighing a metered volume of, say, 50 gallons. Assume that the net weight of an indicated delivery of 50 gallons is 200 pounds. The only way to relate the 50 gallons to the 200 pounds is by a factor of density, or weight per gallon; by dividing the 200 pounds by the weight per gallon of the liquid, we arrive at what the meter should have read. But if our density figure is not correct, then the percentage crror will include an error caused by the testing method, but which appears to be a meter error. If the test nethods are carefully checked to see what their accuracies are, we won't run into such trouble. Now, if the temperature error is relatively large and the temperature correction is not made, our procedure is in error. Under different conditions the variations would be different. Unless we know exactly what the conditions are, the tolerance would have to be large enough to cover the worst conditions encountered.

Mr. Perkins. Have you encountered any temperature increase within the meter as a result of the setting of the back-pressure valve?

Mr. Hessee. We have found the temperature increased in the meter from the back pressure and also from the bypassing of the liquid around the pump. When the bypass on the pump is operating, the $904381-50-7$ 
liquid tends to heat up more rapidly, and of course that heated stream goes right through the meter. The heat effect causes temperature variation over a wider range, and a test run under those conditions must be rejected unless you can integrate over the entire temperature range and arrive at an average density.

Mr. Promins. I think that is one of the reasons why we have stayed with the volumetric method, with the vapor return. We do not slow down ouir pump. We get a delivery at the full speed of the equipment, and I think that is why our temperatures are in very close agreement.

Mr. Baucom. Please explain the effect of a drop in the pressure on the volumetric measuring system, from 225 pounds pressure down to a point just above vaporization.

Mr. Perkins. We would not get any drop in the process of measure. Vapor returns are used throughout. Our test measure is filled from the bottom and there is very little agitation. We try to get merely a displacement of the vapor rather than any vaporization. That is what we base the whole test on. We always reject the first lun. WVe try to get everything equal-pressure and temperature-and then make rapid runs; that is very important.

'The Chamman. In our code the tolerance for a normal run is 2 cubic inches per gallon in excess or in deficiency; on a slow run it is 3 cubic inches. Also, "the 'normal' test of meter shall be made at the maximum rate permitted by the installation. The amounts delivered shall not vary from the standard by more than the tolerances hereinafter provided, (1) during continuous or intermittent discharge of liquid, (2) when operated, in the case of a meter of less than 2 inches, at a rate not less than 7 gallons per minute, and in the case of a meter of 2 inches or more, when operated at a rate which is 20 percent of the manufacturer's marked maximum rate or a rate which is $1 / 3$ of the 'normal' maximum rate permitted by the installation, whichever is less."

I noted from Mr. Hessee's paper-an excellent paper, by the waythat you were lumning down as low as 5 gallons per minute. Is that correct?

Mr. Hessee. That is quite true. Would you tell us your experience on slow tests?

Mr. Perkins. We have found tremendous errors. One meter put on the market about a year and a half ago showed an error of 1 percent for each gallon-per-minute difference in the rate of flow. That meter would normally operate at about 20 gallons per minute in filling a customer's tank with a vapor return. But if no vapor return is used the delivery rate is slowed down. We were finding errors as high as 15 to 20 percent in excess on that particular type of meter. That is another reason why we have used the volumetric method with the rapid run in an effort to get a true run.

We also use the slow run to prove out the meter. It usually shows the actual condition of the meter very well. If the meter is in good condition the error will not be great, but if the meter is badly worn the errors on the slow rum will be far in excess of the tolerance.

Mr. Hessee. I should like to comment on the vapor return with respect to the accuracy of customer deliveries, as distinguished from the ability of the meters to measure liquid accurately. Assume that we have a tank truck containing liquid at a relatively high tempera- 
ture, and that the pressure is up to about 120 pounds per square inch. Assume also a consumer's tank with the liquid at a relatively low temperature and the pressure at about 70 pounds per square inch. If a vapor-return line is commected between these two tanks there will be a flow of vapor to the low-pressure tank until the pressures are equalized.

Now the question is, "What amount of vapor has been exchanged?" To determine that, we must know the physical properties of the gas as well as the number of cubic feet of vapor which flowed from one tank to the other; and, of course, we may be dealing with two different gases. Before the operation is started we may have a pressure difference which will cause the net flow to be in one direction or the other. If this net flow amounts to any appreciable percentage of the delivery, the fact that the meter is found accurate on one test with vapor return does not assure the consumer that when the meter says 50 gallons he is going to get a net delivery of 50 gallons.

Now let us assume that our tanks have equalized pressure, that both are at 75 pounds per square inch, that the vapor-return valve is open, and that the liquid-delivery valve is open. For every gallon of liquid going to the consumer's tank, a gallon of vapor is displaced back to the other tank. For the delivery to be accurate under all conditions, it would be necessary that the ratio of the density of the vapor to the density of the liquid be constant. But if you will consult the tables on the properties of saturated propane, you will find that the ratio between the densities of the liquid and the vapor is different at different temperatures; between $0^{\circ}$ and $100^{\circ} \mathrm{F}$. there is about a 5 -percent spread between the percentage figures representing the weight per vapor gallon divided by the weight per liquid gallon. For saturated butane the corresponding spread is about 2 percent.

Therefore, if customer deliveries are made using a vapor return, no single meter adjustment will insure accurate deliveries, and seasonal adjustments of meter's will be required to produce accurate deliveries. If you are going to set up a small "delivery" tolerance and adhere to that tolerance, vapor returns must be eliminated. After you have tested a meter and sealed it, that is supposed to mean that when a delivery is made to the consumer he is going to get the quantity represented plus or minus whatever "meter" tolerance applies. This is not going to be true if deliveries are made with vapor return. I dare say that about 75 percent of the tank trucks in some of the States that are now delivering LPG will not pump this material without vapor returu because the pumps won't build up a large enough differential. The problem is to obtain accurate deliveries without sacrificing practical operation of equipment and safety.

Mr. Permins. I have checked against Mr. Fuller's equipment on numerous occasions, and many times I have duplicated Mr. Fuller's checks and settings which have been by the gravimetric method. I think the largest discrepancy between the two methods has been about one-half of 1 percent.

Mr. Buickley. Under the California code it is permissible to sell LPG by vapor volume. Do you permit vapor-volume meters which measure by the cubic foot but which indicate in some other unit of quantity? For example, would you permit an index on sucl a meter 
to indicate 10 "Happy cooking units" as equal to 1 cubic foot? If not, would you give your reasons?

The Cunmuan. We do not permit that. We specify that sales can be by reight, by liquid volume, or by the cubic foot. 'The reason for that stipulation is that we want to adhere to standard weights and measures. To recognize units such as you mention would be like recognizing a New Jersey gallon, a Califormia pound, or an Arizona mile. We are going to hold to those terms commonly used in the United States, namely avoirdupois pounds and ounces, the United States gallon, and the cubic foot.

Mr. Burcklex. After the measurement has been made in cubic feet or avoirdupois pounds or ounces, would you permit the billing or the invoicing in any other terms than standard weights and measures?

The Chamian. "The answer to that is also, "No."

Mr. Butrolph (Phillips Petroleum Co.). I should like to ask if, in California, you are actually establishing the true accuracy of your metering device, either from a theoretical standpoint or from a practical standpoint.

Mr. Perkins. We have attempted to do just that. Our error has been less than one-half of 1 percent, which we felt was satisfactory. 'The error' caused by expansion is so slight that I disregard it entirely.

There is one thing that should be remembered when comparing our conditions with those in North Carolina and the Middle West. We have no underground systems in California, and our temperatures are nearly equal in the customer's tank and in the delivery truck.

Mr. Butrolph. The reason I asked that question, Mr. Perkins, is that the rapor in the tank originally can represent 3 percent of the liquid volume. So there you could have an error of 3 percent. Theoretically, we have not been able to convince ourselves that the volumetric method of checking is satisfactory. We have been going along with Mr. Hessee-and when I say "we" I mean the American Petroleum Institute-in working out a satisfactory method of determining the accuracy of meters for LPG as well as other hydrocarbons. I would like to say, Mr. Hessee, that a new specific gravity device is being worked on by the Natural Gasoline Association which we hope will be much more accurate than the present device that you are using.

I should like to throw in a word of caution to you gentlemen by saying that in some instances you may condemn meters that are accurate because of error's in your measuring devices or your methods. However, I think you have done a very good job.

Mr. Perkins. I think you lose sight of the fact that we make a complete fill of liquid and return of vapor before we ever start a check. That is, we do not consicler the rapor in the testing tank at all, when setting the meter. As Mr. Hessee has said, if there were a large temperature differential there might be a considerable flow of vapor in one direction or the other. Some of the dealers even install a check valve so that the vapor in their tank cannot flow into the customer's tank, but in actually setting the meter we try to get merely a displacement of the vapor.

Mr. Butcklex. Mr. Brenton, before the completion of your study on LPG and the adoption of your code, was LPG sold in California in units of quality rather than units of standard weight or measure? 
Tine Chamman. Very definitely, yes. In fact, there are vapor meters in operation in California that use indicating elements in the terms Mr. Blickley has mentioned. Our instruction to the owners of those meters is to have them changed. Would you say, Mr. Perkins, that there might be 200 such meters?

Mr. Permixs. There are probably a few more than that. There are some that register in pounds. Of the approximately 6,000 vapor meters in California I would estimate possibly 300 to 400 are registering in something other than cubic feet. When requests for changes have been made our recommendations have been well received and suppliers or owners hare cooperated fully. The only objection I have had so far has been from some of the meter manufacturers.

Mr. BuтtoLph. I realize that in the State of California there are very few vapor meters, and that it has been no problem to change the dials and go back to the cubic foot. But we are not all in the same situation. Actually there are over 500,000 meters registering in decitherms. Between here and the Rocky Mountains there are over one million vapor meters in service. To change those meter's now would create a tremendous economic problem. We have had long discussions with Mr. Blickley on this, and I respect his opinions and arguments. I think that he would have had no argument from us or from any part of the industry had we discussed this matter twenty years ago when we started ont.

(At this point, at $12: 55$ p. m., the Conference adjourned, to meet at $10 \mathrm{a} . \mathrm{m}$., Thursday, May 25, 1950.)

\section{TOUR OF BUREAU OF STANDARDS LABORATORIES}

During the afternoon of Wednesday, May 24, a 2-hour tour of selected laboratories of the National Bureau of Standards was held for those attending the Conference. Delegates and guests participating were divided into small parties, each in charge of a guide.

(On the erening of Wednesday, May 24, an informal party was held at Wrardman Park Hotel, the Conference headquarters, for those attending the Conference.) 


\section{FOURTH SESSION-MORNING OF THURSDAY, MAY 25, 1950}

(The Conference reassembled at 10:10 a. m., C. C. Mundy, Vice President of the Conference, presiding.)

\section{REPORT OF THE NATIONAL CONFERENCE COMMITTEE ON SPECIFI- CATIONS AND TOLERANCES, PRESENTED BY J. P. McBRIDE, CHAIR- MAN, AND DISCUSSION THEREON}

During the course of the year your Committee has had under consideration the codes as appearing in NBS Handbook H44, and in accordance with its established practice, has solicited suggestions from the Conference members and industry. In December 1949 a communication was received from the National Association of Scale Manufacturers suggesting major changes in the scale code in several instances and requesting an opportunity to be heard by the Committee in support of its proposals. In January of this year a communication from the Secretary of the Committee was directed to the State weights and measures offices and to industry advising them of an interim meeting of the Committee to be held on February 13-15 at the National Bureau of Standards and requesting suggestions from these sources in relation to any proposed changes in the several Conference codes as published in NBS Handbook H44. Your Committee notes from the tone of the replies that there appears to be a general feeling of satisfaction with the codes as most recently amended at our last Conference and a thought that these cocles should be afforded a reasonable opportunity to work out as now existent. All submitted matters were placed in the Committee agenda for consideration at its meeting, and arrangements were made for hearings for those parties manifesting a desire to be heard. Your Committee assembled in executive session on February 13 and continued in session during the entire day. On February 14 hearings were granted to the Technical Committee of the National Association of Scale Manufacturer's (which recommended a number of changes in the scale code), to a general group representing the Gasoline Pump Manufacturers' Association (which made no recommendations for changes), and to one individual. Considerable material was submitted at the hearing and the Committee gave careful consideration to all proposals presented to it. Your Committee now has to advise that it was unable for various reasons to act favorably on a majority of such proposals. TVe have found that in one instance an error was made in one of the codes as submitted at the last National Conference. The Committee believes that some strengthening of requirements is desirable, and accordingly makes some proposals on its own initiative.

The conclusions reached by the Committee at its February meeting were embodied in the "Tentative Report," which was distributed early in April. Since that time, several new matters have come before the Committee, and during the past several days the Committee has 
met on a number of occasions. The conclusions of the Committee in relation to the matters most recently considered are embodied in the "Final Report," copies of which have been available here since the opening of this meeting on Tuesday morniug.

The complete recommendations of the Committee are, therefore, covered by the two reports in your hands, the Tentative Report and the Final Report. The specific recommendations contained therein are presented to the 35th National Conference on Weights and Measures for consideration and action.

$$
\begin{aligned}
& \text { JoHn P. McBride, Chairman, } \\
& \text { R. W. Sumtr, Secretary, } \\
& \text { G. I. Austin, JR., } \\
& \text { Naylas Berryman, } \\
& \text { Lovis E. WITT, } \\
& \text { Committee on Specifications and Tolerances. }
\end{aligned}
$$

Mr. McBrine. In presenting the specific recommendations of the Committee, I shall first state the recommendation and shall then add such explanation as seems appropriate. Following our customary procedure, I shall then move the adoption of the Committee recommendation, in order to get this formally before the Conference for action. [Reading:]

\section{SECTION ON GENERAL CODE}

\section{Add three new General Regulations, as follows:}

G-R.3. Suitability of Equipment.-Commercial equipment shall be suitable as to design and capacity for the service in which it is used.

G-R.4. UsE of ADJUSTMENTs.--Weighing elements and measuring elements which are adjustable shall be adjusted only to correct those conditions which such elements are designed to control, and shall not be adjusted to compensate for defective or abnormal installation or accessories or for badly worn or otherwise defective parts of the assembly. Any faulty installation conditions shall be corrected, and any defective parts shall be renewed ol suitably repailed, before adjustments are undertaken. Whenerer equipment is adjusted, the adjustments shall be so made as to bring performance errors as close as practicable to zero value.

G-R.5. Method of Operation.--Equipment shall be operated only in the manner which is obviously indicated by its construction or which is indicated by instructions on the equipment; if operated in any other manner the equipment shall be subject to condemmation.

Mr. McBride. Proposed G-R.3. is intended to provide a specific general requirement which may be cited by an oflicial when he finds in use equipment which is unsuited for the service in which it is being used. I move the adoption of General Regulation G-R.3.

(The motion was seconded, the question was taken, and the motion was agreed to, thus adopting General Regulation G-R.3.)

Mr. MCBride. Proposed G-R.4. and G-R.5. are based upon present Liquid-Measuring Device Regulations R.4. and R.5., and it is the opinion of the Committee that these sound provisions should be extended to all commercial equipment. If G-R.4. and G-R.5. are adopted as proposed, liquid-measuring device regulations R.4. and R.5. and Grease-Measuring Device Regulation R.1. will become unnecessary. I move the adoption of General Regulations G-R.4. and G-R.5.

Mr. Bavcon. Would it be binding upon the inspector, to accept any notation which might be placed on a scale or a meter? Would 
the inspector be required to abide by the instructions rather than by the code?

Mr. McBride. It would be binding on the inspector, because the instructions would be a directive to the user of the device as to the intended method of operation of the device.

Mr. Bivcour. Suppose a meter were marked to show a minimum rate of only 50 percent of its maximum rate?

Mr. McBride. The manufacturer could not mark a device with instructions not consistent with the code; he could not vitiate or nullify the code by such instructions.

(The motion was secouded, the question was taken, and the motion was agreed to, thus adopting General Regulations G-R.4. and G-R.5.)

\section{SECTION ON FABRIC-MEASURING DEVICES}

\section{Mr. McBride (reading) :}

Amend the first sentence of paragraph 'T.1. by changing the final period to a comma and alding the words, "except that the acceptance tolerance on underregistration shall be not smaller than $1 / 4$ inch", so that the paragraph will read as follows :

T.1.-Maintenance tolerances on under-registration and on over-registration shall be as shown in table 1 ; acceptance tolerances shall be one-half the maintenance tolerances, except that the acceptance tolerance on under-registration shall be not smaller than $1 / 4$ inch. (The er'or of a fabric-measuring deviceto which the tolerance is applied-is the difference between the indication of the device and the corresponding actual length of testing tape passed through the (levice.)

The slight change in the acceptance tolerance on under-registration for fabric-measuring devices is recommended to meet a manufacturing condition which has been reported to the Committee. The proposed change is considered by the Committee to be entirely justified under the circumstances. I move the adoption of the amendment to tolerance paragraph 'T.1. as proposed by the Committee.

(The motion was seconded, the question was talien, and the motion was agreed to, thus adopting the proposed amendment to tolerance paragraph T.1. for fabric-measuring devices.)

\section{SECTION ON CORDAGE-MEASURING DEVICES}

\section{Mr. McBride (reading) :}

In table 1, change the heading of column two to read "On over-registration", and change the heading of column three to read "On under-registration".

An er'ror was made assembling the material for this code, resulting in the reversal of the captions of the two columns in table 1 of tolerance paragraph T.1. I move the adoption of the changes proposed by the Committee.

(The motion was seconded, the question was taken, and the motion was agreed to, thus adopting the proposed changes in table headings in table 1 under paragraph T.1. for cordage-measuring devices.)

Mr. MCBRIDE (reading) :

The Committee is cognizant of the tentative status of the cole for cordagemeasuring devices. Since the 34 th National Conference in 1949 the Committee has been investigating cordage-measuring devices with reference to the provisions of the code, and has found that some improvements in these devices, as presently designed, are desirable. It is believed that the manufacturers should have a further opportunity to improve their product before final action on the code is proposed. It is the intention of the Committee, during the coming year, 
to keep in toucl with this situation, probably conducting performance tests of the devices from time to time. Accoldingly, it is the recommendation of the Committee that the code for cordage-measuring devices be continued in its present tentative form until 1951, at which time it is anticipated that recommendations for final adoption of requirements can be made.

I move that the code for cordage-measuring devices be continued in its present tentative form until 1951.

(Tlie motion was seconded, the question was taken, and the motion was agreed to, thus continuing the tentative status of the code for cordage-measuring devices.)

\section{SECTION ON LIQUID-MEASURING DEVICES}

Mr. McBride. Since the Conference has now adopted General Regulations G-R.4. and G-R.5., Liquid-Measuring Device Regulations R.4. and R.5. are no longer needed. I move that these regulations be deleted from the code for liquid-measuring devices, and that present liquid-measuring device regulation R.6. be renumbered to become R.4.

(The motion was seconded, the question was taken, and the motion was agreed to, thus deleting regulations R.4. and R.5. from the code for liquid-measuring (levices.)

\section{SECTION ON GREASE-MEASURING DEVICES}

Mr. McBride. By reason of the adoption of General Regulation G-R.4., Grease-Measuring Device Regulation R.1. is no longer necessary. I move that regulation R.1. be deleted from the code for greasemeasuring devices.

(The motion was seconded, the question was taken, and the motion was agreed to, thus deleting Regulation R.1. from the code on grease-measuring (levices.)

\section{SECTION ON SCALES}

\section{Mr. McBride (reading) :}

At the end of paragraph T.1.2.2., relative to minimum tolerance values, change the final period to a colon and add a new proviso, so that the pragraph will read as follows :

T.1.2.2. ON AUtomatic-Indicating Scales.-On a particular scale, the maintenance tolerances applied shall be not smaller than one-fourth the value of the minimum reading-face graduation; the acceptance tolerances applied shall be not smaller tlian one-eighth the value of the minmium reading-face graduation: Provided, that on pre-packaging scales such as are defined in paragraph S.23., the maintenance tolerances applied shall be not smaller than one-eighth ounce and the acceptance tolerances applied shall be not smaller than one-sixteenth ounce.

Prior to the development of the prepackaging of perishable foods for "self service" in retail markets, the weight portions of computingscale charts ordinarily were graduated by 1-ounce subdivisions. Now, however, the computing scale companies have developed the so-called prepackaging scales, having $1 / 4$-ounce subdivisions. Having in mind our present acceptance tolerance requirement for a minimum tolerance equal to one-eighth of the value of the minimum reading-face graduation, a scale with $1 / 4$-ounce graduations would be required to lespond to a $1 / 32^{-o u n c e}$ weight; the ability of computing scales to meet this requirement is debatable. It appears entirely reasonable to the Committee to amend paragraph T.1.2.2. by the addition of the proviso recommended, and I move that this Committee recommendation be adopted. 
Mr. REese. In Iowa there is a great deal of prepackaging of fresh meats. Meat will shrink, and packages which were full weight when packaged are out of tolerance when offered for sale.

Mr. Buvcom. Is the Committee going to recommend a reduction of the maximum value of the minimum graduation on prepackaging scales?

Mr. McBuide. The Committee is not recommending any change in the present requirement that "The value of the minimum graduation on a scale used for the retail sale of foodstuffs shall be not greater than 1 ounce."

(The motion was seconded, the question was taken, and the motion was agreed to, thus adopting the amendment to scale tolerance paragraph T.1.2.2.)

Mr. McBride (reading):

In the first sentence of paragraph T.2.3.3. change "5 percent" to "3 percent", and change "3 percent" to "'2 percent", so that the paragraph will read as follows:

T.2.3.3. For WHEel-LoAd WEIGHERS. - The basic maintenance tolerance for individual wheel-load weighers, on under-registration or on over-registration, shall be 3 percent of the known test load; the basic acceptance tolerance on under-registration or on over-registration shall be 2 percent of the known test load. When two wheel-load weighers are tested as a pair, the tolerance shall be applied to the sum of the indications of the two weighers, and the pair shall be approved or rejected upon the basis of the combined indications.

The manufacturers of wheel-load weighers have improved their devices so that they now feel they can meet a finer tolerance than we have heretofore specified. The Committee feels, therefore, that the tolerances for wheel-load weighers should be reduced. I move the adoption of the Committee recommendation.

Mr. M. W. Jensen. Would this change be retroactive?

Mr. McBride. Yes. Tolerances are retroactive.

(The motion was seconded, the question was taken, and the motion was agreed to, thus adopting the Committee recommendation relative to tolerance paragraph T.2.3.3. for wheel-load weighers.)

Mr. McBride. You have now completed your consideration of the entire Report of the Committee on Specifications and Tolerances. I wish to thank you for the reception given to $\mathrm{H}-44$. 'The codes are being generally accepted without major change, and the Committee is pleased to know that we have been able to combine a series of codes that has proved so acceptable to you gentlemen. We have tried to give you, in language as simple as possible, codes that will be workable, and I believe that we have achieved a large measure of success.

\section{PREPACKAGED PERISHABLE COMMODITIES}

THE MARKETER'S VIEWPOINT-REMARKS OF R. G. CARPENTER, MEAT PACKAGING SPECIALIST, THE GREAT ATLANTIC \& PACIFIC TEA CO.

Ever since the general store and the proverbial cracker-barrel days, most changes in food retailing have involved packaging. With the development of the self-service super food market in the early 1930's these changes became one of not just packaging for self-service. The meat department in our concept of the modern food store has been one of the last to be bitten by the self-service bug. Although this method of merchandising was looked upon with favor by those closely associated with the retailing of meats, the application to these products presented many problems which were difficult to overcome. 
The lack of uniformity in quality, trimming, and appearance of individual meat cuts made it imperative that any consideration along these lines provide visible packages.

Meats, unlike many other perishable products, are extremely sensitive to change in appearance as well as change in condition. Most meats lose that bright, fresh-cut appearance some time before they actually become out of condition. The very marked change which takes place in the appearance of meats as they lose their bloom made it a necessity that any packaging materials employed provide, along with visibility, product stability from the standpoint of appearance as well as condition.

The development of Cellophane was probably the greatest single factor contributing to the successful growth and development of selfservice meats. In fact, sliced bacon was one of the first products ever packaged in Cellophane. Even with the development of Cellophane, however, progress was slow. Lack of refrigerated self-service display facilities discouraged any real enthusiasm for the idea. It was not until 1941 that such equipment became available.

With the advent of the first refrigerated self-service meat display case, interest grew rapidly not only among retailers, but among packaging material suppliers, packers, and equipment manufacturers as well. The war, and the extreme shortages of meat, tended to retard further expansion. However, sufficient interest had been created so that today new and improved packaging materials are continually becoming available, packaging know-low is improving, and continued improvements are being made in display equipment. Despite the progress which has been made to date, however, self-service in the meat department is still a relatively new field and might be considered in the experimental stage. The packages still look a little bit on the amateurish side when compared with the packaging being done in other fields.

We are not going to try and discuss today the advantages or disadvantages of self-service in the meat department from a merchandising standpoint. We are going to talk about self-service and its effect on correct quantity and price determination, which is the phase of the development in which we believe you gentlemen are most interested.

The A\&P Tea Company, in their anxiety and concern to safeguard the public's interest, in the operation of our markets, pioneered the development of Customeread computing scales, so that the customer could assist in checking each transaction. Today we have specialists whose chief responsibility is checking the accuracy of our scales. With the growth of self-service in the meat departments, we cooperated with the various scale manufacturers in the development of scales particularly designed for prepackaging. 'The new scales which are now available for use in such operations provide for a far greater degree of accuracy both in the weighing and computation.

More important, however, than the mechanical improvements in the scales, is that the weighing and pricing in a self-service meat department becomes a specialized phase of the market operation. It provides for the weighing and pricing of numbers of packages of similar items prior to sale. Therefore, the price-per-pound factor is kept constant in computing the several transactions. Persons are chosen as scaler's who show the greatest aptitude for this type of work. They 
are then trained to prepare them properly for their duties. In addition, since they have no other responsibilities at the time, the scaling and pricing is given their undivided attention.

In operating our markets, we have the person doing the scaling indicate his or her number on the label. This provides the market managers and supervision the opportunity for checking their accuracy. It also tends to place greater responsibility upon the individuals doing the scaling.

It is not only, however, just in the actual mechanies of scaling that we provide greater protection to the consumer as well as being of real assistance to the weights and measures inspectors. It is the recording of all of the details of the transaction on the self-service label. On ou1 labels, we provide all of the information which is required by law as well as other information which we feel is pertinent. IVe provide a description of the product, the exact net weight of the contents weighed to the quarter ounce, the price per pound, and the total computed price, as well as our name as distributor. In addition, we indicate in code the day of the week the package has been prepared. All of this information, including the price per pound, is most essential if full value of the protection afforded through self-service is to be achieved. From our observation, error in retail meat transactions has not been a question of weight alone, but-most important-the computation of the price. In the absence of the price-per-pound indicated on the labels, it would be impossible to check this factor accurately.

Probably all of the many reasons why weights and measures inspector's have always looked with favor on the prepackaging of staple commodities would also be applicable to meats. With self-service meats, they are provided an opportunity to check the accuracy of the scales and the accuracy of the retailer's weighing and computing of a representative variety of the many products being handled-not just single transactions. With all information such as weight, price per pound, and computed price clearly indicated on the self-service packaged meat label, it greatly simplifies the inspector's task of checking such operations.

The most difficult problems in the development on self-service of meats have had to do with proper packaging materials. As we mentioned earlier, materials employed had to provide a good, substantial, visible package-they had to keep the meat in good condition and maintain the appearance of the product for a salable length of time.

Since Cellophane was first employed as a wrapper on sliced bacon, inmumerable studies have been conducted on this subject. Today there are a number of packaging materials which perform reasonably $\pi$ ell. Color or appearance retention was, and still remains, one of the most difficult phases. This problem divided itself into two groups: Cured meats, such as hams, bacon, luncheon meats, etc., and Fresh Red Meats such as beef, lamb, veal, and fresh pork. Strange as it may seem, cured meats have been the most difficult in this respect. These products derive their color from the nitrates and nitrites used in processing. This color is extremely sensitive to light or oxygen. In the absence of either of these two factors, color can be retained for a satisfactory length of time. Cured meats, when kept in the dark, if packaged in Cellophane or other transparent materials, keep their bright color. Exposed to light, they fade and lose their bloom rapidly. The only way the light 
factor could be eliminated was through discarding the visibility, which is so important from a sales standpoint. If oxygen were to be eliminated, it would require the application of a highly air-tight and moisture-proof material.

All of the studies which had been conducted on packaging materials for use in meats, however, had to throw out the possibility of a moisture-proof, air-tight, packaging material. Meats liad to breathe. 'These products are all of a high moisture content, and are continually exuding moisture. In a completely moisture-proof package, moisture retained on the surface of the product became the breeding ground for bacterial action and hastened the rate of spoilage. It has been found, however, that cured meat products can be packaged in a moisture-proof container on which a vacuum has been drawn. In the absence of any air whatsoever on these products, even though packaged in a moistureproof material, the bacterial action is sharply retarded. This operation, however, still presents additional operating difficulties.

In the absence of any alternative, most cured meats today are packaged in material such as LSAT Cellophane which permits these products to breathe and tends to absorb some of the moisture given off. Retailers are compelled to strive to control the disadvantage of fading through turnover, reduction in light intensity, and, in some instances, going so far as to turn the package upside down.

Until just a few year's ago, the packaging of Fresh Meats was not practical since no materials had been developed which would keep the bloom on them even for a matter of a few hours. In April 1944 the Du Pont Company, with the cooperation of the A\&P Tea Company, developed MSAT-80 Cellophane. 'This film and others developed since do a really remarkable job in keeping the bright, freshcut color on fresh meats for a workable lengtl of time. Here too, however, it had to be recognized that these products had to breathe. Control over the rate of the moisture dehydration was a contributing factor to the success of these films. The other was the providing for' the presence of oxygen on the surface of the product, which is just the opposite to what was necessary on color retention for cured meats.

Providing for the presence of oxygen on fresh meat products is largely accomplished through the porousness of that side of the film which comes in contact with the meat. In developing suitable packages for the individual meat items, it was found that cardboards and cardboard trays were sometimes desirable to give the package rigidity. With these materials too, it was necessary to provide for controlled amounts of moisture absorption in order to protect the product properly.

All meats have a relatively high moisture content. They are constantly being dehydrated. In presenting retail meat items to the customer in self-service units, those materials which provide the degree of protection necessary and yet present the product in an attractive manner, although they tend to control and sharply reduce this dehydration, cannot eliminate it entirely and still provide the protection which is necessary. Such moisture loss usually is absorbed by the packaging materials employed. The relative degree of dehydration within the packages will vary widely depending upon the type of meat, cut of meat, temperature, and time. As a retailer, we 
are conscious of this problem and are taking every precaution to insure proper weights at all times. All of our tests on the subject indicate that the shrinkages concerned are relatively small and, where there is a rapid turnover of product and good low-temperature refrigeration, do not exist to any measurable degree. However, it still remains a difficult problem.

Part of the difficulty is the procedure employed in the interpretation of the weights and measures regulations in the different communities. As a retailer operating stores in many sections of the country, we find it difficult in setting up standards for our self-service markets to insure absolutely that we are not only giving our consumer full measure but that we are also in strict conformance with the rules and regulations of that community covering proper quantity determination. The procedures by which weights and measures inspectors check the activities of self-service packaged meat departments are varied. In some instances in checking these markets, inspector's strip the packaging materials from the package and weigh the contents. Since, as we have mentioned before, it is necessary in the packaging of meats to employ materials which tend to pick up limited amounts of moisture which must of necessity be given off by these products, slight shrinkages may be detected. Some jurisdictions have attempted to recognize this condition and established shrinkage tolerances varying from an eighth of an onnce to the ponnd to a quarter of an ounce to the pound.

It is difficult for us to conceive, however, how this is a practical solution to the problem. It is an impossibility to set a specific pattern for the shrinkages involved on different cuts of meat and under the constantly varying conditions.

The practice which we have observed on the part of some inspector's which we feel to be more practical, and which should tend to protect the customer as well as to provide some degree of protection for the retailer, is that of weighing the package itself, and then weighing a dummy package of the packaging materials used to insure that there had been adequate tare allowance provided for the packaging materials.

Another problem concerns a package produced by the packer. As you have probably already observed, there is a continually increasing wider selection of packer prepackaged meats being made available to retail meat dealers. Recently, in their efforts to produce packages that would lend themselves more attractively to self-service, the packers are now preparing some products, such as picnics, processed in a transparent cellulose casing. On such products, it is going to be impossible or impracticable for the retailer to strip off this casing in order to determine the net weight of the product. The Meat Inspection Division of the Department of Agriculture, in interpreting the regulation that requires that each packaged meat product car'ry a net weight before leaving the packer's plant, have interpreted these cellulose casings to be a part of the product, similar to the casing on a sausage, since these materials are employed in the processing of these products. We hope that the local weights and measures authorities will follow a similar interpretation in exercising their responsibilities in checking these products. We, as a retailer, feel it important, in 
our anxiety to protect the consumer, to be in conformance with local weights and measures regulations.

In summing up, we would like to say that never before in the history of the retail meat business has the cristomer been given the degree of protection with respect to weights and pricing that is hers in the selfservice meat department. We know that you will agree that your problems as weights and measures inspectors will be simplified many times over with the further development of self-service in the meat departments. We trust that you will bear in mind some of the problems confronting the retailer in developing the procedures for checking his activities.

\section{THE MARKETER'S VIEWPOINT-REMARKS OF CHARLES SIEGEL, NATIONAL ASSOCIATION OF RETAIL GROCERS}

I have been asked to speak today on the subject, "Prepackaged Perishable Commodities-The Marketer's Viewpoint". I want to warn you at the outset that my experience in the field of prepackaged perishables is somewhat limited-in fact it embraces a period of less than five months of actual operation. At the same time I do not want to convey the impression that our company made the swing to prepackaged perishables "blindfolded." For years prior to the changeover I had read and studied all available subject matter as well as acquiring a great deal of valuable information at conventions and forums within the food industry. Still, I make no claim to being an expert and so, with this understood, I shall content myself with attempting to pose questions and ideas which may, perchance, open up avenues of further discussion from the representative group of specialists here present.

Our store is in the downtown section of Richmond in an area where Negro patronage constitutes more than half of the volume. It is a long, narrow building and traffic, particularly on week ends, is unusually heavy. When we first considered changing to 100 percent selfservice meats, everyone warned of the disastrous conseqnences. I began to doubt my own judgment in the light of the many powerful arguments advanced against its practicability. Our kind of business, they said, was different. Negroes, of all people, would never take selfservice-they wanted to see their meats weighed. The white customers, in the main composed of families of the "old school," would insist on meats cut-to-order. The venture was deemed to be foolhardy.

For a time the question was whether or not to pay heed to these wellmeaning advisers. Under such circmmstances a decision is difficult to arrive at. As previously stated, our store is a narrow affair and week end traffic has always been a problem. The long waiting lines at the counter and the jostling confusion of Negroes and whites definitely did not make for an ideal situation. In spite of these negative opin.ions we went ahead with our plans and to date have not regretted it. Shortly after the installation of our Self-Service Meat Department we ran a full page in the local newspapers, explaining the innumerable advantages to be enjoyed. The ad contained only a handful of items and prices, most of it being devoted to copy of an educational or "come and see for yourself" nature. The response was terrific and except for one or two past events of an unusual character, we did the biggest 
business in the history of our store. And I am happy to report that this upward spiral is continuing.

To be sure, we had some complaints at first, but I dare say that if a survey were made among our customers today, 90 percent or better would express complete approval of self-service meats.

Let's review the advantages of this type of operation both from the marketer's and consumer's angle, for in each case they are manifold. I cannot point to any noticeable saving in overhead for usin fact we have had to "up" our personnel by one or two employees, but they are women working in the packaging department and commanding considerably less by way of income than skilled meat cutters. We also have a substantial wholesale meat business and some of our cutters have thus been diverted, either whole or part time, to other activities.

The important thing I wish to emplasize, however, is that our meat business with 100 percent self-service has and is continuing to increase, and due to greater traffic, a beneficial effect upon all other commodities is being steadily manifested. We have found, moreover, that self-service meats have more "eye appeal" - the customer with limited money to spend aroids embarrassment at the counter. Also there is the important factor of sanitation. Under the old method, many patrons had the habit of personally handling meats, and in a store such as ours, catering to mixed trade, there were everpresent and well-justified doubts of cleanliness.

Most of you in session here are, quite naturally, interested in prepackaged perishables from your own perspective of weights and measures. While I realize that I am "sticking my neck out" by dealing with this phase of a subject on which you are so well informed, nevertheless I am going to air some of my views and reveal certain weaknesses prevalent under this new method of packaging. May I say in advance, horrever, that while our store has its own share of problems, prepackaging and otherwise, the following are not among them:

1. Short Weight And Overeharging.-These "bugaboos" can be largely overcome by first fixing prices a cent or two per pound higher and allowing $1 / 4$ ounce for shrinkage, provided needs beyond two days are not anticipated.

2. Tare Al7owance.-Some merchants apparently overlook the fact that only the net contents can be priced to the customer. They should be reminded otherwise.

3. Proper Refrigeration of Smoled Meats.-There is a tendency to display these atop the case or in mass floor displays, with a resultant shrinkage of 10 percent or more in a matter of days. This practice should be discouraged. All smoked meats except those of old eure should be kept under refrigeration.

4. Handling of Fish.-Fish live in water and consequently their weight consists of a higher-than-ordinary percentage of water and blood. A low mean temperature must, therefore, at all times be maintained for firmness, congealment, and avoidance of excessive shrinkage. The proper level should be 28 to 30 degrees.

In conclusion, it would seem to me that the extent of dehydration in prepackaged perishables is our momentous problem. With differing climatic conditions and varying moisture content, depending upon the solidity of beast, fish, or fowl, it is difficult to arrive at any accurate standard for advance determination of shrinkage. Until such time as we can scientifically gauge these differentials and depend upon the honesty and judgment of individuals, you members of the various Bureaus of Weights and Measures must keep unceasing vigilance. 
INFORMATIVE LABELING AND ENFORCEMENT PROCEDURES-REMARKS OF H. E. HOWARD, SUPERVISOR OF WEIGHTS AND MEASURES, CITY OF MIAMI, FLA.

In the abstract, labeling need not necessarily be in print for the analytical mind. Conversely, labeling as applied to the sale of commodities must be evidenced in concrete form.

Being an exponent of the school of thought, that an apology is in order for a long presentation of a subject because there was not enough time to prepare a shorter one, I submit the following:

Since the advent of self-service for prepackaged commodities and its increasing popularity, the work of a weights and measures official is doubled, as it is necessary to check the marked price as well as the marked net weight, on such commodities. Close supervision must be maintained to nullify a great potential loss to the buyer and possibly the seller:

To facilitate this double-checking operation and give the buyer full information on the commodities displayed for sale, our Division promulgated the following regulation. It was included in the City of Miami Ordinance No. 3573 and adopted the 19th day of May, 1948.

Self-Service, Freshly Packaged Meats, Cheese, and Similar Commodities:

When put in package form and out of the presence of the purchaser, shall be plainly and conspicuously marked as to price per pound, except when packaged in standard sizes of one quarter $(1 / 4)$, one-half $(1 / 2)$, and one (1) and multiples of the pound. Price tags shall not be used to conceal bone or undesirable portions of such commodities in transparent wrappings. Weight markings shall indicate to the nearest quarter (1/4) ounce.

'Thus the price tag will slow the "Price per Pound," the "Net Weight," and the "Price" for the net weight indicated. This permits the purchaser, the market supervisor, and the weights and measures inspector to make an "on the spot" check or inspection at any time. The regulation is simple enough that no legal or technical claritication is required.

Tare weight is compensated for by using a duplicate container as a counterbalance, therefore net weights are read directly on the scale. A check of ten packages of at least five commodities ( 50 packages) is considered a representative check. Usually two delicatessen items and three meat items are checked.

In checking we use a "Weight-Price Inspection Report" form (see fig. 20), which records the subject Commodity and Price per Pound, Date Prepackaged, Legibly Marked check, Use of Date Code check. Then for ten individual actual packages, tabulations under "Net Weight (Oz)" are made for "Marked" "Exact", "Over", and "Short", and under "Sale Price (Cts)" for "Marked", "Exact", "Over", and "Under." Tare weight is compensated for by duplicate container.

Next is Totals, Number of Packages, and Average Net Weight, showing excessive or deficient amount and percent; Satisfactory Weight and Price checks, and, for correction purposes, Re-label, Re-package, and Stop-Sale checks are shown. A footnote states that, "Variations from the marked net weight shall be as often above as below."

If items being checked are found on a quick check to be satisfactory (marked net weights and prices being as often above as below with $904381-50-8$ 
CITY OF MIAMI, FLORIDA

DEPRRTMENT OF

DIVISION OF WEIGHTS G MEASURES WEIGHT-PRICE INSPECTION REPORT

DEALER

DATE INSPECTED TIME

ADDRESS

DATE PREPACKAGED

Legibly Marked Yes $\square \quad$ No

Dote Code Used Yes $\square \quad$ No $\square$

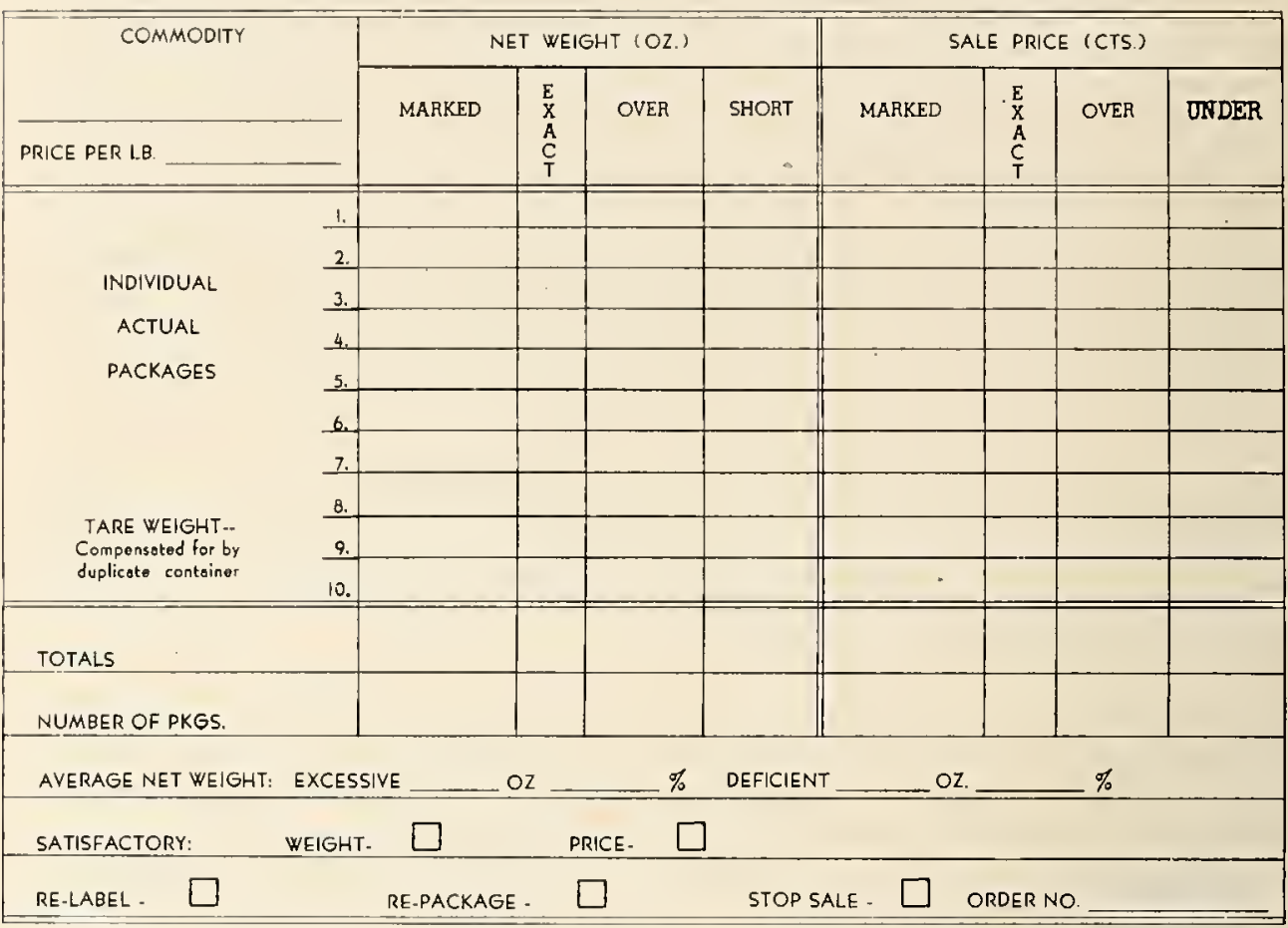

REMARKS:

Copy to:

OWNER OR AGENT

Note. Variations from the marked net weight shall be as often above as below.

FORM 965

Figure 20. Weight-price inspection report form-City of Miami, Fla.

no unreasonable variation), the form can be filled in by check-marking the columns instead of actually marking in the amount of variation. The report will then show only the number of packages in their respective columns.

'The report is signed by the owner or agent and the inspector. A copy is given to the owner.

In Miami we have good cooperation with the market operators. It is understood that there are 16 ounces in a pound, no more, and 
certainly no less. For the inspector to clear a bin or possibly a whole case of items with a re-label, re-package, or stop-sale order indicates a weakness iu market management. Our market managements are very strong in Miami.

One of the big reasons for this cooperation is that every merchant knows that each and every one of his competitors is complying with the regulation. Some chain stores use it outside our jurisdiction because it tends for better merchandising and checking purposes.

The power of suggestion is often greater than the power of command for a lasting enforcement. Our prosecutions are relatively few.

In conclusion, I would say that if the weights and measures official is equipped with the proper regulations and the market operators are indoctrinated as to compliance with these regulations, confusion and complaint can be reduced to a minimum, thereby making the selling and buying transaction a happier one.

The regulation also applies to special order's unless scales are so positioned that the customer may see the weighing operation of his purcliase. This eliminates a pacliage coming out of a service window with only the price marked on the package.

In the absence of "Price per Pound" marking on the individual package, the purchaser has no means of checking the value represented unless he is a wizard at mathematics. Therefore, he is at a loss to compare values in one store with those of another. I consider it a prime duty of any Weights and Measures Department or Division to initiate regulat ory legislation so that the buying public will not, at the time of purchase, be confronted with solving an equation with an unknown factor. The price per pound marking also eliminates the possible deceptive or misleading bin prices-for example, a small " $1 / 2$ " marked inconspicuously in pencil above the "lb" mark on a price tag.

When a minimum weight marking of one ounce is used it is easy enough to note a discrepancy of five-cents or more on items in the higher price range. This prompted the requirement for $1 / 4^{\text {-ounce }}$ weight marking.

The uniform placing of price tags, usually on one side of an odd shaped or round package or on one corner of a rectangular package, makes a neater display and shows the customer there is no intent to cover anything in the package that might be irregular.

Since the buyer is entitled to the marked net weight, the question of shrinkage may arise. The merchant may make an allowance at the time of packaging or he may use a "date code" system which will enable him to determine how long any item has been packaged. Then if the time element causes any appreciable shrinkage, he will know when to recheck any such items. If commodities are packaged and stored, marking should be made at the time of display. Whatever method of packaging is used, the buyer is still entitled to the marked net weight.

In making weight-price checks we use exact weight scales with a one-pound beam graduated in $1 / 4$ onnces, the one ounce over-and-under indicator having $\frac{1}{16}$-ounce graduations. 'Thus the use of unit weights is eliminated, which makes a faster operation. Prices are checked instantly with a book of weight-price charts. Thus an inspector makes a complete check with his own equipment without interfering with the merchant in his normal operation of business. 


\section{DISCUSSION ON THE THREE PRECEDING PAPERS}

Mr. A. J. Mayre. I should like to ask Mr. Carpenter about picnics. Those being shipped into Louisiana weigh from $1 \frac{1}{2}$ to 2 pounds. They are not marked to show their net weights and they are not even sold by the pound; they are sold by the piece.

Mr. Carpenter. You probably have reference to smoked butts; picnic hams would run considerably heavier than $1 \frac{1}{2}$ to 2 pounds. If those products are not wrapped and identified as a self-service unit then our instructions to our organization are that they must be sold at a definite price per pound, that they must be stripped of their wrappers, and that they must be weighed and priced to the consumer at the time of sale. If our people are not doing that, you can rest assured that we will correct any condition of that sort that exists. Variableweight products in our meat stores must be sold at a definite price per pound, and if these products are not prepackaged and available for self-service, they must be stripped of their package wrapper and weighed and priced at the time of sale.

Mr. A. J. MAYEr. I did not mean to say that this was done directly by the $A \&$ P stores. 'These butts are shipped to many of the smaller stores in the State.

Mr. Carpenter. In our opinion it is impossible to sell equitably, at a unit price, variable-weight merchandise in a meat department. I can think of no instance where we would condone or tolerate such a practice.

Mr. J. T. Kennedy. It is my feeling that whether or not the inerchandise is stripped at time of sale, prepackaged merchandise should be somewhat overweight. I wonder if it is the fact that where weights and measures enforcement is effective a little more is put in, and where weights and measures enforcement is not effective, the merchandise is packed absolutely net weight. In the District of Columbia we require an overage.

\section{THE RESPONSIBILITIES OF THE OFFICIAL TO HIS WEIGHTS AND} MEASURES ASSOCIATION

Br J. R. Jones, Commissioner of Agriculture, State of South Carolina

In accepting the invitation to speak to you today on the responsibilities of the official to his weights and measures association, my thoughts revolved around the word "responsibilities." Webster's dictionary defines the word "responsibility" as meaning "a charge for which one is accountable." The plural of the word-that is, responsibilities-merely increases the number of charges for which we are accountable.

As an official, either elected or appointed, each of us is familiar with "accountable charges." The day we assumed our duties we gave some form of oath that we would be ever mindful of the charges we had pledged to undertake. Many of the responsibilities were made by our predecessors, some we made ourselves; and the active, alert official is continually studying and acting on the advice of others, in order to broaden his responsibilities. Let us discuss briefly the sincerity with which we approached our responsibilities. 
Tn thinking of the subject given me- "The responsibilities of the official to his reights and measures association"-I should like to draw a picture starting with the work in the field, then the man in the field, and then the directing officer in the line of their work.

Year's ago I began my career in public service as a weights and measures inspector in my State; a State which had a limited number of large buying and selling centers, and a great number of small rural center's, joined together by either a "jerk water" rail system or a narrow, muddy, washboard road.

Those of you who date back into that era can well recall the rail trips made from one small town to another. With a thirty-pound kit and your fiftr-pound weights parked in the express office, you would trudge for miles and miles around these scattered rural centers in an effort to find the business places. If there rere any platform scales, that meant hiring a binggy or a wagon. If the scales were bad you helped the merchant adjust them. Scale mechanics were few and far betreen; they lived in the big centers and in many cases would not accept any out-of-tomn mork. Inspectors had to be strong, active men in order to keep up the pace of "in torm in the morning and out that night." He had to be a man of strong personality because reights and measures laws were new and the merchant had to be won orer the see the value in them.

Of course, the actual duties of the inspector were limited to counter scales, small-capacity platform scales, liquid measures, and here and there maybe a thumbtack rard measure. A rard of material was measured from the extended arm to the tip of the nose in many of the drygoods stores. If you bought a piece of dress material from "short-arm Susie" you needed seven yards. If you bought material from "lean and lanky Mabel," six yards rere sufficient. It may be interesting to hear' some of the old-time inspectors relate how "checks" were made on these measurements without accounting for the charges. Hotrever, these pioneers undoubtedly met their responsibilities properly for I know the remarkable strides that have been made in weights and measures are a result of their missionary work.

Through the years that have transpired since my "inspector dars" up to my present position, it has been my pririlege to see the service of protecting the public grom in latitude and in the esteem of the merchant and the customer. Responsible to the people of my State for the administration of the Department of Agriculture, I find my duties raried. Enforcing weights and measures laws is just one of these varied duties. Naturally. my time is divided, but with reasonable care in selecting personnel, we feel we have been able to keep abreast of the times.

We have tried to malie our representative realize the full importance of his work-proud of his privilege to be in the service, and deeply conscious of his responsibility to industry, to the consumer, and to his State. These three requirements are the rock bed foundation of public responsibility, whether the official is city, county, State, or Federal.

Let me digress here for a minute to sound a general warning about conditions that could enter into our field of serrice. We are mitnessing today the tug-of-war between the forces that would destroy in- 
dividual thinking and action by substituting "controlled" human beings, and forces that would hold to our democratic way of life. 'The former" are caller by all kinds of "isms" except Americanism. Proponents of these "isms" are insidious in promoting their well-planned schemes. They build empires of controlled thinking and controlled action under the guise of alleviating the responsibilities of the public.

I have seen evidence of a great deal of this kind of thinking creeping into public services and I regret to say some of the proponents are wholly innocent of the ultimate breakdown of our free enterprise. I have seen some of this thinking creeping into our weights and measnres circle, but I am thankful to say it has not gained a foothold. Once in a weak moment, I also considered plans which could have controlled the thinking in our weights and measures division, but when I stopped to figure the cost, I dropped it like a hot potato.

Ours-yours and mine-is a responsibility that has grown through mutual understanding and cooperation to meet a public need. In our case the public is made up of the producer, the seller, and the consumer. Our responsibility to these is equal. In the scheme of "isms" one or more of these will eventually be eliminated.

The continued success of our National Conferences will depend largely upon keeping our deliberations democratic. As long as those, who by constitution promulgate the thinking of these democratic deliberations, continue to adhere to the principles of free enterprise, their success will continue. The continued success of our associations with each other will grow if we practice these democratic principles, accepting them as our paramount responsibility.

Let's turn our attention to some of our everyday responsibilities. First among these is directed toward the authority we hold in selecting, training, and supervising the personnel who enforce our weights and measures laws. Shall we enforce these laws by instilling fear in our public, by using cold-blooded police tactics, or by education, the result of which will bring voluntary cooperation and respect?

In thinking of illustrations to emphasize these points, I am reminded of an experience in my own organization and of one of our fellow directors. This fellow director was a city official in one of our large Southem cities. One day the administration sent him a six-foot brute of a man to train as a city inspector. Our weights and measures friend had gained his position through merit, and was conscious of the responsibility attached to an inspector's job. During the training period, he tried to make this new appointee realize the importance of his new work. The first day he sent him ont alone, the director received a phone call from an excited merchant, demanding that the director come to see him at once. It turned out that this new appointee, filled with the importance of his position, had gone out on his route with a shining badge pinned to his coat lapel and a gun strapped to his hip. Naturally, the public resented his appearance and his attitude.

In my own organization, we had in one of the other divisions of the department a young man whose work and ability to get along with people had attracted my attention. Although he was a fine office man, he was really an outdoor person and had asked me to give him an opportunity to work in the field whenever there was an opening. One day the opening came and after a period of training which all of our 
new field men go through, this young man was assigned his routes and sent out on his own. Long hour's meant nothing to him, neither did hard work, but the freedom of the outdoors bronght to him a sense of freedom in his personal appearance. Being so mnch out of doors he became rugoed, so to speak, in his dress, careless with his equipment, and adopted a careless attitude toward his position and the importance with which it was regarded in his territory. Soon merchants were asking me, "Who is the little boy you have working in our" territory"?

As administrative officials, our responsibility begins with the men in the field. Are they qualified to do the rork? Do they have complete knowledge and understanding of the laws they are out there enforcing? Do they carry themselves as ambassador's of good will and good gorermment? Do they command respect and enjoy fellowship in the places of business where they go? Do the consumers have confidence in their Tork? Do they talk, live, act, and conduct themselves so as to lend dignity to their profession? Do their activities convince the merchant, the manufacturer's' representatives, and repairmen that they not only know the laws but they know what procedure is necessary to enforce these laws?

The Weights and Measures profession is as strong as the men who enforce its laws. How can we obtain a uniformity of service and meet our responsibility? I wonder if we could say that uniform specifications and tolerances will do much to bring about this uniformity. If the administrative officer will be specific in his requirements, and human yet positive in his tolerance, he should be able to build up his personnel whose work will command the respect of everyone. True knowledge of specifications and tolerances can be best worked out through mutual understanding and associations, whether they be applied to human beings or to mechanical devices.

Mutual associations begin with the inspector and his supervisor, then the city, county, or State groups and their directors. These are followed by the State organization, the Regional organization, and finally the National Conference. These steps form a link, and the good of one sifts through from the bottom to the top, and vice versa-from the top to the bottom. This good that is sifted through all these various channels broadens all of us and puts us in a better position to meet the "char'ges for which we are accountable."

If, as director's and officials, we agree that these are the stepping stones to uniformity, then it behoores us to sponsor more active associations among the men in our field of work. This may not necessarily mean a greater number of associations, but it does mean greater interest in the associations which are already organized.

Realizing the value of organized associations, and seeing the need of greater interest in South Carolina, we called our first State Conference in 1949. Our Second Annual Conference was held this past April, and I camnot begin to measure the influence these meetings have had in broadening the knowledge of our inspectors, as mell as those of us who handle the administrative duties of weights and measures in South Carolina. These conferences have given us a keener appreciation of the ideals of the Southern Association, and this fine gromp of men has assisted us in developing greater respect for the National Conference, and we feel its influence in our rork. 
The promotion of Weights and Measures is an honored profession. The ranks are filled with some of the keenest minds I have ever met. Through organized associations we bring together the thoughts and ideas in constructive discussions and they naturally have influence on, and become a part of, the whole profession. Since we are a part of this profession, either through our connection in city, State, or Federal work, it is our obligation to support and become active in these organized associations.

Let's get behind State Conferences and carry the message to our own groups. Let's back up our Regional Associations with constructive enthusiasm. If you are asked to serve on a committee and accept the appointment, give that committee every ounce of your interest and effort. If you accept an office or some special assignment, give that office or that assignment your full attention and complete cooperation. If you do not belong to an association, then join your association and when once joined, support it with your presence, your active interest, and your full cooperation.

I feel that our failure to act on any committee to which we have been named is not only a personal reflection but it is discourteous to other members of the committee. While I am on the subject of courtesy and discourtesy, let me add that nothing is so irritating as to have someone ignore a letter and fail to reply to something to which you have given time and sincere thought. If your committee chairman writes you, even about the most unimportant matter, give him a reply if nothing more than to acknowledge his letter. We all have clerical help and the least we can do is to answer a letter, which, after all, will undoubtedly be to our mutual interest.

I guess we have all heard over and over again, "Let George do it." Yes, there will always be a George to do the work, but we should also feel some responsibility in being one of the "Geor'ges." Let's join the number of Georges in our association work.

We who are here today are attending the most important of all our Conferences, for it is from these National Conferences that the culmination of all of our thinking is washed, dried, and ironed out, then placed in consumer packages. Since we have been privileged to be here, we should feel some responsibility in passing on to those who are not here the benefits we shall reap from this conference.

It is from these National Conferences that all the "fine" in weights and measures is put in printed form to hand on down for both the present and the future.

I do not know how many States are represented at this Conference, but I do know that every State has some form of weights and measures law, therefore, every State should be represented here. If every State is not represented, perhaps the blame lies within us. Have we failed to let enough of the good in our other associations sift down to them? If we have been negligent in our responsibilities toward these States. this, then, is a "charge for which we must account."

Let's add to the revival spirit now sweeping our country and make a pledge that 1951 will bring about closer associations with each other and stronger association organizations.

City, county and State lines are fast disappearing, therefore our responsibility camnot stop at our local level. We are no longer a part of our individual group, we are a part of the whole profession. Our 
responsibilities face us in every step of weights and measures, even up to this National Conference.

Let us face our responsibilities and accept the "charges for which we are accountable."

\section{REPORT OF THE NATIONAL CONFERENCE COMMITTEE ON WEIGHTS AND MEASURES EDUCATION, PRESENTED BY J. T. KENNEDY, CHAIRMAN}

Members of your Committee on Education have continued the policy of attending as many State and regional weights and measures conferences and schools of instruction as practicable. We have also taken adrantage of every opportminity to contact and confer with weights and measures officials outside our own jurisdictions. In the process of making these visitations, we have emphasized the importance of weights and measures education. We have especially stressed the need for greater effort in belialf of education among our own ranks. The more we study this phase of weights and measures education, the stronger is our realization of the urgent need for more organized and concerted activity in this field.

The principal medium which is being employed in the education of weights and measures officers is the State and regional conferences held amnnally. We are glad to report, again this year, that all twelve of the State and the two regional associations, have held meetings or schools since the 34th National Conference. Some of the associations have sponsored more than one meeting or school. In addition to the meetings sponsored by State and regional associations, the South Carolina Department of Agriculture has sponsored two conferences, of two days each. Quite an elaborate school was sponsored by the State Department in New Jersey. A special two-day school for State Inspectors was conducted by the Virginia State Department. A special school was held in North Carolina by the State Department, also a three-day school was held in Ohio, in addition to the anmual meeting and four regional meetings. In California, New York, the District of Columbia, Minnesota, Oklahoma, Louisiana, and some other States, interim meetings, district conferences, or schools of instruction have been held. Your Committee wishes to compliment all of these jurisdictions upon their excellent edncational activities. We urge you to continue and to expand your efforts. We also recommend that additional jurisdictions institute similar programs.

The public relations programs in Chicago and Detroit, which we mentioned in our report last year, are being continued. The State of Virginia has had their motion picture, which was previewed at the 34th Conference, in use in that State and also in another jurisdiction. Los Angeles County, California, has remained active in the public relations and public education field. The results that these programs are producing are self-evident.

Although considerable progress is being made in the weights and measures educational field, it is apparent to your Committee that too many weights and measures officials are not yet fully mindful of their rightful responsibilities in this comnection. We have endeavored, repeatedly, to emphasize the fact that there is but one way to promote weights and measures administration, and that is, through education. The "educating" must be done by the weights and measures officer" 
himself. Nobody else will do it for him. It must be done in the three definite steps which your Committee has enumerated in the past, that is, through the education of (1) the weights and measures official, (2) the merchant, and (3) the general public. This job cannot be done by a committee. It cannot be done by a few weights and measures officials. It will take the constant best effor's of all officials, in every jurisdiction. Youx Committee does stand ready, willing, and anxious to assist any official or juristiction in the plaming or execution of an educational program. We have made this offer repeatedly, but have received few requests.

In its report to the 34 th Conference, your Committee made seven specific recommendations. So far as we have been able to learn, these recommendations have received very little attention. We are still of the opinion that they were good recommendations. We suggest that you read these recommendations in the Conference report. The second recommendation in that list had to do with the preparation of two hundred or more fundamental questions that all weights and measures officials should be able to answer. Your Committee has prepared two lists of questions, together with the answers to one of the lists. These questions and answers will be furnished to anyone desiring them, upon request to the Committee Chairman, or Secretary, or to the Office of Weights and Measures of the National Bureau of Standards. We hope that the requests will be numerous and that each weights and measures officer in the United States will study the questions and learn the correct answers. It would be our suggestion that the individual officer be supplied with the questions, and that he work out his own answers, before he consults the list of answers prepared by the Committee. 'This should encourage study and research.

Our recommendation number six was, "That the Bureau of Standards be requested to repeat the Weights and Measures School when the demand justifies it, and to further explore the field of rendering greater assistance in the actual training of State and local officials in practical field activities." While the Bureau was quite agreeable to this request we regret to repor't that there has been mo demand for repetition of the Weights and Measures Training School on the Calibration of Standards. This is very valuable training. Each State and each large local jurisdiction should have at least one staff member with this specialized training. If your department has not taken advantage of this opportunity, we suggest that you give the matter your careful consideration.

Your Committee has but one new recommendation to make to this Conference. We do wish to renew all recommendations made in previous reports, however. The new recommendation has to do with the prompt exchange of information by weights and measures officers. This is being done to a limited degree, in some States, among their own persommel. It is accomplished, to some extent, by the issuance of "News Letters" or "Bulletins", in other jurisdictions. Some of these News Letters and Bulletins are given considerable circulation outside of the States which publish them. This is particularly true with respect to Indiana and Texas. California and Ohio have given their Bulletins some out-of-State distribution, also. We are glad to report that the Southern Weights and Measures Association has resumed the publication of its "News Letter." Mr. Howard E. Crawford, Chairman of the Southern Association Committee on Education, is the editor of this 
publication. If you ale not on his mailing list, we suggest that you contact him.

'There is another phase of this idea of "exchanging information" besides the publication and distribution of news letter's and bulletins. It is the "exchange of corlespondence and copies of correspondence", on various subjects. TVe are all interested in "uniformity." The principal object of the National Conference is to achieve "uniformity" in laws and regulations and in the interpretation and enforcement thereof. The better understanding we have of what the other fellow is doing, and why he is doing it, the more "uniformity" we will have in reights and measures administration. Our idea is for weights and measures officials to collaborate with one another and with other interested parties and to keep others informed as to their decisions and activities.

This idea was the subject of the remarks of the Committee Chairman, in an address before a State reights and measures conference, during the past year. A few representatives of industry did not take to the idea with favor. 'They later voiced this disfavor to the speaker. We, your Committee, camnot conceive of how a program which results in the enlightenment of weights and measures officials, and in greater uniformity of enforcement methods and procedures throughout the country, could fail to be beneficial to the manufacturer, the merchant, the consumer, and the weights and measures official.

We submit that if such a program is successful and beneficial in one or more States, it is reasonable to assume that it would be proportionately beneficial on a national scale, through the cooperative efforts of all active and progressive oflicials. We are not attempting to suggest the mechanics to effectuate such a program, but we do suggest that it should be practicable to establish such a program designed to produce the following results:

1. Better understanding of problems encountered in various areas.

2. Uniformity of enforcement.

3. Increased efficiency in operations.

4. Uniformity in approval and rejection of commercial equipment.

To succeed, such a program must have the full support of all cooperating officials; it should have the full support and cooperation of all active departments.

It must be understood, and your Committee desires to make it perfectly clear, that we are not suggesting a "National Committee on Type Approval." That is not in this report. We do feel that a cooperative program of exchanging weights and measures information promptly, entered into voluntarily by active and progressive weights and measures officials, on a nation-wide basis. will help to prouluce the desirable results enumerated earlier in this report. It will also tend to eliminate confusion (and sometimes, embarrassment) which now exists as a result of varying actions in different jurisdictions. We submit this general idea for your careful and deliberate consideration. 'Think it over' and discuss it with your fellow weights and measures officers.

In conclusion, we urge that all weights and measures officials not only continue, but redouble their educational activities. Enlarge your present programs and institute new programs. See to it that each 
staff member in your department becomes a "perpetual student," and do all that you can toward the further enlightenment of the general public along weights and measures lines.

\author{
J. T. KENnedy, Chairman, \\ W. S. Busser, Secretary, \\ G. E. Carpexter, \\ R. K. Slough, \\ RobenT Wildiams,
}

Committee on Weights and Measures Education.

Mr. Crawrord. As Chairman of the Committee on Education of the Souther'n Weights and Measures Association, I have had the opportunity of learning something of what the National Conference Committee on Education has accomplished and what they have provided in the way of valuable material. I feel that an effort should be made to make this information available to every official or representative of industry who cares to have it at any time. I feel that our radio interviews and addresses and newspaper stories and other educational material should be published and put into the hands of every official. I liope that our Committee can make it possible for us to have this information without request, so that it will be available at the time we need it.

(It was moved and seconded that the Report of the Committee on Education be adopted, the question was taken, and the motion was agreed to.)

(At this point, at 12:30 p. m., the Conference recessed for luncheon.) 


\section{FIFTH SESSION-AFTERNOON OF THURSDAY, MAY 25,1950}

(The Conference reassembled at $2: 15$ p. m., C. A. Baker, Vice President of the Conference, presiding.)

\section{PROBLEMS INVOLVED IN SETTING UP A NEW WEIGHTS AND MEASURES ORGANIZATION}

ADMINISTRATION-REMARKS OF T. C. BECK, ASSISTANT DIRECTOR, MARKETING DIVISION, STATE OF OKLAHOMA

Such a topic as mine covers a multitude of sins. And I do mean sins. At any rate it would most certainly be an imposition to attempt to outline to you all of the problems encountered in the administration of a new weights and measure program. We are not pessimistic but, after all, there's nothing like giving it to you straight from the shoulder. Yes, we've met with a lot of difficulties; moreover new ones continue to arise, but thanks to an abundance of perseverance and plain old hard work we have managed to surmount most of our troubles up to now.

First, and we believe most profound, of our many worries probably has its origin from the fact that no appropriation of funds was provided for the administration of our law. In lieu of an appropriation the State legislature established a schedule of inspection fees, in the law, for funds to carry out the provisions of the Act. 'There are those of you in this room having similar set-ups who can readily appreciate the fact that a great deal of animosity stems from the fee system.

And, after all, we cannot deny the good old American right to gripe, even though we are very often on the receiving end. Of course, it does rather go against the grain when some of the more vitriolic accusers go so far as to say that we are in cahoots with the scale industry, and proceed to vindicate their wrath upon our inspectors in other less dignified forms of vilification. Nevertheless, we have remained undaunted and we are making headway, although it has not made our Weights and Measures Division appear any more angelic in the eyes of a great many firms who had their scales recondenned and retagged with that abhorrent crimson tag, especially after they had already shown good faith by having hired a scale mechanic and paid what they beliered to be an exorbitant fee. Such an episode was particularly revolting to one group of merchants who learned, to their dismay, that one State-licensed, "master mechanic" had absconded for" parts unknown and left them holding the bag - or I mean, the tag. He has not, as yet, been apprehended. 'The situation was rectified, howerer, by reason of the fact that we were fortunate in having a good scale mechanic connected with our Division.

It should also be said that certain State newspaper articles have not been conducive to a complacent attitude. One such article hinted broadly of ubiquitous chicanery on the part of State officials because of the fact that their inspection tours were promptly being followed by scale salesmen. 
As a means of learning when condemned scales have been repaired we adopted the more or less customary procedure of requiring the mechanies to send in the red tags. 'The owners of condemned scales are given a thirty-day period in which to have them fixed. Then we fail to receive these tags in due time, the scale orner receives a mild reprimand in the form of a letter, for being delinquent. Very often these people reply to the effect that their scales have been properly repaired and upon a more thorough investigation, in some instances, it lias been extremely exasperating to learn that some of these tags liad been stowed away for three or four weeks in the glove compartment of the mechanic's automobiles; which, incidentally, might account for those suspicious looking stains on some of the tags.

It should go without saying that our weights and measures law was not enacted unanimously by the State Legislature; therefore, the static from that angle continues to disrupt the program. Some of these misguided demagogues have assumed the responsibility of disseminating antagonistic propaganda among their constituents to our utter consternation for our diligent efforts. In all fairness we must say that we believe most of these legislator's to be honest in their convictions. They simply do not understand the program. Nevertheless their attitude and actions act as just one more serious demoralizing factor with which our Division is forced to cope.

At this point one of our most exasperating enigmas should be mentioned. In all probability this is a dilemma in which the administrators of most any new weights and measures program find themselves fioundering. I refer to the herculean task of securing an adequate number of qualified repairmen to fix the scales and retrieve the red tags as fast as a small crew of State per'sommel can inspect and condemn the scales. 'This is especially true where it is necessary, as in our case, to condemn approximately 75 percent of the small-capacity and 60 percent of the large-capacity scales examined. This irksome paradox results in a titanic amount of insumountable perplexity.

Then, we are nonplused by the arduous entreaty from the merchants with a story to the effect that their scales are only off 4 ounces and that the scales are slow and, therefore, cheating the seller instead of the buyer anyway. Some argue that the scales are accurate up to 12 or 15 pounds and that they seldom weigh more than 4 or 5 pounds at a time. so why spend $\$ 25$ or $\$ 30$ for repairs when the tolerances are entirely too rigid and impractical for the poor, hard pressed, indigent, povertystricken merchants. And of course we do realize that a large percentage of the grocers, at least, have only recently emerged from the status of a neighborhood store in the front room of a residence to a mdernistic, drive-in supermarket. As for this mique progress we can only proclaim, "More power to them !" Our only interest is to endeavor to administer our weights and measures program in such a manner that such miraculous prosperity will not occur, or be contributed to, by inaccurate scales or short-weight packages. Our policy, of course, in regard to all other State industries is the same.

Another quagmire in which we find ourselves entangled is the difficulty of trying to keep pace with the demand for inspections of heavycapacity-type scales. This unprecedented demand for State testing of large scales is probably due to the fact that there has been in existence in Oklahoma, for the past four years, a voluntary scale-testing service 
which had already gained a sizable measure of participation. Inability of our Division to cope with these requirements is due to the fact that we liare not as yet acquired sufficient equipment for the work. We are at present negotiating for additional facilities, but as a good many of you know, this also takes time.

Refusal of some firms to pay the inspection fee, as you can readily appreciate, also presents a dilemma involving delicate intricacies. Thus far, however, we have been able to collect practically all outstanding accounts by means of ominous letters originating in the Oklahoma City Oflice. At this point it is emphasized that by far the greater part of the fees are immediately paid directly to the State inspectors when the scales are tested.

So far we have refrained from prosecuting any violators, in the belief that prosecutions in the early stages of a program creates a vindicative attitude among the industry involved. Instead of prosecutions, we have experienced fairly satisfactory results by issuing letters of warning and using such letters as a matter of record against offender's. In this connection, of course, we realize that a certain number of prosecutions are ultimately inevitable. It will never be the policy of our Division, however, to impute common peccadilloes to ordinary citizens, thereby implicating them in unnecessary imbroglios.

Although the matter of maintaining a proper filing system in the office was not mentioned in the beginning of this discussion, it is by no means an insignificant trackless wilderness through which we have been forced to tread.

It is realized that we have painted an extremely gloomy pictnre of the subject matter, but we would not have you conclude that it has all been bad. On the contrary we have derived an abundance of pleasure and satisfaction in connection with the project. Also we have had splendid cooperation from certain segments of industry, including the Secretary, Manager of the Oklahoma Retail Grocers Association, farm organizations, civic groups, and others. After all my topic does relate to the pessimistic approach to the situation and does not propose a solution to the various perplexing intricacies with which we are confronted.

We realize that it will quite ostensibly be a matter of years before we reach a utopian status, and at this time we wish to emphasize a profound desire and urgent need of a lot of good old-fashioned fatherly advice, especially from those of you "unfortunates" who have a fee system operating in your State. Any advice from you between now and the close of this session will be received with immeasurable gratitude.

We are still floundering in the quagmire of raw recruits, but we are anxious to scale the heights of Mount Olympus. Please do not fail to help us.

TRAINING-REMARKS OF A. J. MAYER, DIRECTOR, DIVISION OF WEIGHTS AND MEASURES, STATE OF LOUISIANA

The training of the personnel of an organization, in my opinion, makes the difference between success and failure, not only in weights and measures but in any other organization. In our State of Louisiana prior to 1949 , there was no State-wide weights and measures law, but 
in the city of New Orleans there was a fee system, or a charge of seventy-five cents per scale (small types only). The organization consisted of two inspectors, and their total equipment for testing purposes consisted of two 1-pound weights. It finally wound up in a scandal, so the Legislature decided to enact a law, which became Act 95 of 1948 , adopting State standards of weights and measures. This Act created a Commission composed of the Governor, the Collector of Revenue, and the Commissioner of $\Lambda$ griculture.

To put the law into operation, it was recognized as being essential that only personnel trained in weights and measures work could properly do the job in a creditable manner without imposing undue hardships and injustices on the users of weighing and measuring devices in the conduct of their work. It was also recognized that a well informed inspector of weighing and measuring devices could correct any reasonable inaccuracies of such devices without the necessity of sending the same away for adjustments, thereby causing the owners mudue expense as well as the loss of the use of the equipment while away. Such personnel was not available; therefore, the period from the time the law became operative until February 1, 1949, was used in training personnel and acquiring suitable equipment with which to do weights and measures work.

To begin with, the Director was sent up to the National Bureau of Standar'ds, where he took a course in its training school. He also made several visits to different State weights and measures offices to gather data, information etc., relative to said work.

We gradually built up our organization, selecting personnel as we thought best, considering the conditions in our State. The men selected for inspectors were given a thorough schooling, which included public relations, a thorough study of Handbook H44, which was then H29, and a visit up North and East to several scale manufacturers to get the actual fundamentals in both light- and heavy-duty work. In one instance we spent several days in training in a scale inanufacturer"s school.

It now gives me great pleasure to express my sincere thanks and appreciation to Dr. F. U. Condon, Director of the National Bureau of Standards, Mr. Ralph WV. Smith and Mr. W. S. Bussey of the Bureau's Office of Weights and Measures, and other personnel of the National Bureau of Standards, to the Directors and personnel of the several States we trained in, and to the several scale mamufacturers who were so cooperative and helpful in the schooling of our men.

It goes without saying that without this training our Division could not have made such strides as it has made in giving to the public the services a weights and measure organization should give. In 1949 over 60 per cent of weighing devices, etc., were found inaccurate, and so far as this year is concerned we have brought it down to less than 15 percent.

As to the cost, I'll give you the actual cost to the public. It is not more than four cents per capita, and the approximate saving was over forty-six cents per capita. In other words the approximate saving was about $\$ 1,500,000$ to the public in our State, due to the 
services of weights and measures in obtaining a fair and just return on consumer purchases.

In closing. let me thank you one and all for the wonderful cooperation you have giren us in bringing our State where it rightfully belongs in its weights and measures work.

\section{PUBLIC RELATIONS-REMARKS OF G. L. JOHNSON, DIRECTOR, DIVISION OF WEIGHTS AND MEASURES, STATE OF KENTUCKY}

I am delighted to be asked by $\mathrm{Mr}$. Ralph Smith to prepare a paper on public relations in "forming" or "setting-up" a new Weights and Measures Division. I must quickly admit that I am not a writer nor am I qualified to read too well.

In presenting this paper on this subject I would like to give you, as best I can, the trials, troubles, and tribulations as we have met them in this respect in Kentucky.

I have experienced public relations in Kentucky as to passing legislation and creating public sentiment for our work. Creating good will is by far the most important step in any governmental agency. We were not too well established in Kentucky when we took orer in $194 \mathrm{~s}$. Te had but few records of the work accomplished by our predecessors; in fact, we practically had to work out our own salvation. I do not mean that our predecessors did not do a good job, but their records were not too well kept for us to get a grounding immediately.

Public sentiment is definitely the most important job for our department. If and when the public is acquainted with our work, our battle is half won. Without the interest and cooperation of the people we are at a loss to get our work done, regardless of how hard we labor at it.

We realized our trouble when we walked in our office in 1948 . The people of Kentucky had little idea of what we were doing in the Weights and Measures Department. The Department of Agriculture was well established, and when you mentioned the Department of Agriculture you were told that it was a State department to better livestock breeding, and the like. The people in Kentucky had in their minds that our Department, generally speaking, was set up to adrance the Kentucky State Fair-that we were Fair folks. So we set out to publicize the activities of the Department which I head. We needed legislation badly and we realized it took two years at the best to acquaint our people with facts to lead to passage of necessary lams in the General Assembly. We prepared editorials for newspapers and through the fine influence of our Commissioner. Harry F. Walters, we got the job done. Mr. Walters had the fine ability to prepare his messages, and coupled with his personality and enthusiasm, his story of and for better weights and measures for Kentucky was sold to the people.

IVe did not stop at newspaper publicity. We went to the people ria radio, and put on demonstrations at the State Fair. We have ten field men in our Department who are leaders in their communities, men who know the pulse beats of the people, and these field men have kept us posted as to what was best and what was not best. Our field

$904351-50-9$ 
men are good politicians, and in Kentucky we must play politics which is really only the essence of government. 'Through our field men we feel that we are conversing with the people at all times.

We made it a point to see the political leaders of our General Assembly after we had gotten our feet on the ground. We wanted to do a good job. The politicians of Kentucky listened to us at the last General Assembly in early 1950 which led to the enacting of our present law. This law or legislation was prepared by the Statutes Revision Commission last summer in order: that we have suflicient time to study and prepare the bill. I think we will all agree that plenty of time should be allowed in preparing new legislation and, as I find it, it is much easier to prepare and pass legislation than to repeal unworkable laws already on the statute books.

Another important factor is to place your proposed legislation into the hands of a respected legislat or who is in harmony with the Administration or the majority of the Assembly. The proper time must be picked for introducing such legislation. Also you must be on your guard to prevent opposition from lobbyists of the different companies affected by the proposed legislation. In our particular case, this last year, we had to tack on four amendments which did not alter the value of the bill in any way. However, it served as a peace offering with the lobbyists, and after introducing such amendments, they worked for us instead of against us in passing this legislation.

One of our largest difliculties was to keep our bill from being "bottlenecked" or "tied up" in the committees, or "pigeon-holed" as so often happens to legislation. Once you start your legislation it is a good policy to keep it rolling through both Houses and get it acted upon as soon as possible. We have found that it takes a lot of work to pass any legislation. You must contact the legislators, explain to them what the bill is, and once they understand the bill it will be very beneficial.

If all General Assemblies in the United States are like Kentucky's, it is difficult to pass a law and, at the same time, ask for a sufficient appropriation to carry on its work. Therefore, the Commissioner of Agriculture is allotting the Division sufficient money to carry on these functions until the next General Assembly, when we probably will ask for a specific appropriation. I am glad to say that our bill received not one opposition vote either in the House or the Senate. The Governor signed it, thus making it a law that goes into effect July first of this year.

We feel quite confident that the people of our State are ready and anxious for this work to get under way, and we plan other educational activities prior to starting our new Division in July, such as constant publicity in the press and talks before luncheon clubs or at gatherings wherever and whenever we can get the opportunity.

It is, indeed, a privilege to represent the Commonwealth of Kentucky in this important meeting. The ideas and knowledge I have gained and will gain here will be of invaluable assistance to me in advancing the work we are endeavoring to do in our State. 
WEIGHBEAM MAINTENANCE

Br M. J. J. Hankison, Supervisor of Scales and Weighing, Pennsylvania Railroad

At the Thirty-first National Conference on Weights and Measures, held in June 1941, it was my privilege to discuss a few of the essential characteristics and basic design considerations applicable to scale weighbeams of the knife-edge type. Informal discussions subsequent to that presentation-and subsequent to later presentation of the same material before other groups-tended to emphasize the importance of weighbeam maintenance, which is the topic of my remarks today.

There are those who hold that the simple weighbeam is, so to speak, on its way out of the picture. I am not going to argue this point, except to agree that modern equipment for industrial and commercial weighing seems to be provided with a wide variety of indicating attachments, with much emphasis on various automatic and semiautomatic devices. However, this does not mean the abolition of the millions of simple weighbeams that have been provided for weighing scales during the past one or two generations, many of which are in commercial service today and may remain in that service for years to come. It is therefore not inappropriate to examine into the situation and to discuss from a practical standpoint what the weights and measures official has a right to expect from a weighbeam.

My remarks here are by no means intended to outline a manual or set of rules for the service man or the repairman. If I can present you with something that will be instructive to a new inspector-or evell to some older ones-I shall have accomplished my purpose.

Back in 1941, I announced my belief that the three essential characteristics of a weighbeam were truth, stability, and sensitiveness-and after 9 years I have not changed my mind on this. Of these three, truth is obviously of major importance-perhaps of top importance. In considering it, however, we must go further than I did in 1941, for the reason that we here have to consider more than inherent mechanical truth. By that I mean that, in commercial weighing, we necessarily have the manipulation of the weighbeam and its accessories by a person who at least is presumed to be familiar with its operation-such operation being meanwhile observed by a second person who is interested in the transaction, but who may or may not-and is not necessarily presumed to-be familiar with the operating characteristics of that specific weighbeam. 'Ther'efor'e, the first thing' to be done by the weights and measures officer is to examine the weighbeam to determine the presence of any element which may be so manipulated as to cause inaccurate indicated weights. Discovery of such an element, whether connected to the weighbeam proper or elsewhere, would obviously justify official coudemmation of the scale under II44 General Specification G-S.2. and General Regulation G-R.2.

Again, if the normal positions of weigher and observer are such that they respectively see opposite sides of the weighbeam, the weights and measures officer should satisfy himself that, for any normal poise position, the same weight value is indicated on both sides of the weigh-beam. 
A considerable number of commercial weighbeams are of the registering variety. When such a one is examined, it is important to determine that, for at least a representative number of poise positions, each registered weight agrees with the visually indicated weight value. In addition, of course, the registered weights must be clear and distinct and not readily susceptible of misreading. General Specification G-S.5. of H44 is applicable to this detail.

And finally, for this portion of the discussion, the weights and measures oflicer should satisfy himself that the device under examination permits compliance with General Regulation G-R.1. of H44. This is the general regulation covering positioning of equipment so that its indications may be accurately read and the weighing operation observed from some reasonable customer position. It is my personal belief that this regulation may be invoked inversely when circumstances justify-that is, that a reasonable customer position must be provided, from which the indications of the device may be accurately read and the weighing operation observed.

Reverting at this point to mechanical truthfulness of a reighbeam, it would seem obrious that the numerals and graduations on a weighbeam must be readily readable. But we have all seen too many instances where this condition did not obtain. The weights and measures officer has a right to insist on readability, and I feel that he should do so. If the scale owner is not ingenious enough to accomplish this, his repairman may be able to do it. In extreme cases, replacement of a reading face or even of an entire weighbeam may be necessary.

Here we may touch briefly upon some points which are of importance in considering weighbeam truthfulness. Beware of any weighbeam which shows evidence of one or more of its essential pivots having been relocated. All too often this has occurred, if at all, without raking into account the effect of the relocation upon weighing accuracy. Beware of an extra hook-like attachment at the end of a weighbeam. Such attachments have occasionally been used for hanging a bunch of keys on the weighbeam, resulting in a false zero-load balance. Beware of a heavily painted poise. This will frequently result in substantial weighing errors-in a minus direction. Beware of heavily painted counterpoise weights, for the same reason. Beware of a notched weighbeam where the notches and/or poise track show a heavy coating of any kind. Unpredictable weighing errors may be expected here, first because the poise is not accurately positioned and second because the poise rollers tend to pick up this coating, thus altering the poise weight. Beware of a counterbalance cup or a counterpoise cup which is not provided with a fixed lid. (See Specification S. 1.8. 2. of $\mathrm{H} 44$ ). Beware of an installation in which the weighbeam or shelf lever is obviously ont of level, or in which the beam rod or the steelyard rod is obviously not plumb. Unpredictable weighing errors may be expected in eitlier of these cases. Beware of a notched weighbeam in which several of the notches (especially if in a group) are obviously deeper than the rest of the notches. This condition frequently denotes an atten pt to make a weighbeam accurate through only a portion of its capacity or weighing range. And finally, although not exhaustively, prohibit strictly the "mixing" of counterpoise weights - that is, the use on a specific scale of counterpoise weights intended for a scale of some different multiple to the weighbeam tip. 
For onr present purpose, the item of stability may be disposed of rather briefly. 'The basic requirement here is concisely outlined in Specification S. 1. 2. of $\mathrm{H} 44$. As a possible addition or explanation, attention may be directed to the notelied weighbeam heretofore mentioned. In such a weighbeam, it is essential that the tip of the pawl or latch be such that it will fit snugly into each notch, and that the spring pressure which tends to force the latch tip down into the notches be sufficient. These points are of special importance at the zero notch. Is a corollary, the poise must be free-running enough that the poise latch spring and the form of the notch and latch tip, will result in the poise being correctly positioned at any notch.

On any weighbeam, the operation of the balancing means should be positive; that is, if a balance ball is provided, it should be well fitted onto the balance ball screw, and the latter should have no perceptible end play.

As to sensitiveness, this is a characteristic built into the weighbeam by its original manufacturer, presumably to be consistent with the value of the smallest graduation provided. When this quality is once destroyed (except as a result of misalinement), a careful shop operation is usually necessary. Avoid recommending that the pivots be "slarpened up"; in many cases, the results of this are most disappointing. However, in what may be called "mild cases," much good has been accomplished by a careful cleaning of bearing steels with emery cloth and a very light honing of the knife-edges, by a repairman who understood the limitations of what he was doing. Raising or lowering the balance-ball assembly may be effective in some cases, but is definitely not a cure-all. Correction of misalinement, such as an ontof-plumb beam rod, is an obvious step to be taken when necessary.

The foregoing remarks are definitely not all-inclusive. They have intentionally been restricted to the purpose annonnced in one of the introductory paragraphs, and I lope that they will be found useful for that purpose.

\section{A PROGRAM OF LIVESTOCK SCALE TESTING}

\section{Br Eridng Hansen, Supervisor, Department of Weights and Measures, State of Minnesota}

Statistics are tiresome. I hope those that I bring out won't fall on as deaf ears as would my ears be if $I$ were the listener and you, audience, the one to recite the figures. However, without making comparisons, it would be too difficult to impress you with the value of the livestock weighed on the hoof, you who are the only ones that have the knowledge to control the weighing.

The farmers of the United States in $1948 \mathrm{had}$ a cash income of over $\$ 31,000,000,000$. Of this amount almost 15 billions, or abont one-lialf, was for the sale of livestock. This livestock total does not include poultry or dairy products. Fifteen billions of dollars, that is what livestock is worth to the farmers.

In 1948, the entire production of all mineral products in the country, including coal and petroleum products, amounted to only about eight and one-half billions of dollars. By comparison, the value of the mining of coal, both bituminous and anthracite, was short of two billions. I am not trying to belittle the coal industry, nor you who 
are big oil barons, but only trying to show you how great and vast is this industry, that we neglect, and what short weight can mean to the producers. Ol, I know you are quick to say: "Well, look at all the moue the farmers get back from the U.S. 'Treasury in support prices," and "Let them get a little less cash by short weight." But did you ever stop to realize that if the farmers were to lose only 1 percent by weight on livestock alone, this loss would amount to almost $\$ 150,000$,000 ? Makes quite a dent in money spent to support farm prices, doesn't it? 'There were no moneys paid at all to suppor't livestock prices. Remember now, 1 percent taken from the farmer by weight would mean a loss of only 1 pound on the average sheep, $1 \frac{1}{2}$ pounds on the average calf, $21 / 4$ pounds on the average hog, and only about 9 or 10 pounds on the average beef cattle. Do you think anyone could possibly tell the difference? In fact, I'm willing to bet that I could let all of you get on a scale that was set 3 percent in error and there would be but few of you scale experts who would know the difference, even on your own weights. And how can anyone tell the difference of 3-percent short on somebody else's weight, or on animals whose weight fluctuates easily?

What I am going to try to impress on you, however, is that the amount that may be stolen in short weight over the country would knock you off your feet, if you might be a little interested in the subject. To venture a statement as to how much is actually lost to the producer in marketing his livestock each year, is quite difficult. Before I get through with this discourse, I will probably make what may seem to be many rasl statements, but I would like to qualify by stating that I have been engaged in weights and measures control for almost 30 year's, during 25 of which I've been vitally interested in the scales for veighing livestock and in the manipulation of these scales. For 13 years prior to becoming Supervisor of Weights and Measures for Minnesota, I was the scale inspector at the State weighing stations for livestock at the terminal market at South St. Paul and at nine outState concentration points. The knowledge of bad market practices, and poor scales, is something that has set me to raving and ranting for many years. Maybe some day people will become enough interested to do something about it, and be willing to help provide funds for its control. In the last 25 years I have witnessed as much weighing of livestock in different markets, both large and small, as has probably anyone. At least anyone who would be able to tell what kind of weighing was being done. Further, I have discussed this subject with a great many people. I have known several old-time livestock buyers who have let their hair down to tell me that any buyer who can't steal 10 to 15 percent by weight withont official restraint isn't much good.

In 1948, by robbery, hold-ups, pilfering, and embezzlement, there was lost only around $\$ 119,000,000$ in property and money in the entire nation, 50 percent of which were automobiles. However, there was $\$ 67,000,000$ recovered in stolen money and property during the year, so the net loss was only 42 millions. This, I believe, doesn't begin to compare with what is lost in the country in a year's time in short weight practices; furthermore, stolen weight can't be recovered. How many thousand people would you guess are employed for protection against robbery losses, as Federal, State, county, and municipal officers and policemen? If the loss in weighing livestock were ouly 3 percent 
against the producer or seller, the loss would amount to about $\$ 267$,000,000 . How many officers, scale inspectors, and bonded State or reighing officers are employed to protect the sale of this $\$ 15,000,000,000$ worth of gold on the hoof? Not very many I am sure. If the public could only be made to realize this fact!

I'd like to spend the time to tell you of some of the cases of short weight that we have run into, on some of which cases we were lucky enongh to get snfficient evidence to prosecute. It isn't easy to gather the evidence. These buyers are wary ones; they seem to be able to smell an investigator. It would take a staff of experts trained like the F. B. I. to curtail the bad practices. We had one, where 135 pounds was taken on a 900-pound steer from a farmer in the southwestern part of Minnesota. One buyer, as we came mpon him operating his scale, was stealing 15 pounds on every weight in buying calves. Sometimes this buyer felt a little remorse and weighed two at a time and would not gain quite as much. At the same place, later, the buyer was caught weighing 13 pounds short on a single pig. Near Mankato, we were lucky. On complaint, one of our inspectors left his truck at another town and when he got to the buying station the place was empty, the operators were out to lunch. The inspector sat down on a bench in the corner and just waited. It wasn't long before the buyer returned, followed almost immediately by a farmer with a small truck of livestock. The inspector just sat and watched; and when a young heifer was weighed and the check written ont for it, he stepped up and said: "I'd like to weigh that animal over again; I am from the State Department of Weights and Measures." The animal was only weighed 45 pounds short. It was easy to get a conviction and the word got around to the end that the buyer was shamed into leaving town. WVe found evidence in other cases of 10 to 15 pounds taken on a single hog. If this wholesale stealing affected more of the people and not just the farmers, or the crime was more glamorous, such as vice crimes, or gambling syndicates, this story could get wide publicity in the national magazines.

There are many ways for the buyer to short weigh. If the scale inspection is infrequent, the buyer just sets the scale wrong. Remember, he doesn't have to steal much at a time. The price of jivestock is high. 'The producer may have no scale, or if he lias one the chances are that it is a broken-down one, which is even worse. Because his scale is generally weighing slow, as do most dirty and corroded ones, the farmer himself thinks his animal is less weight than it actually is, and he is an easy victim to work on. However, the operator doesn't have to have a false scale. I have watched many of these buyer's operate. They can take 10,20 , or even 30 pounds just by juggling the beam and poises with their fingers. A little off balance to start with, a kick on the beam with their little fingers to set the beam in motion; if it's a type registering beam, flipping the fraction bar back 5 pounds or 10 pounds while punching the ticket; a double bar beam where the lower poise is easily jarred to inch out 4 or 5 pounds a way from zero. The zero notch pounded back 2,3, or 4 pounds, to make a false start. It isn't very hard to fool the farmer. He usually thinks he is so a wfully smart, that he is very easily tricked. For example: One time I showed a superintendent of a distant large stockyard that by moving and juggling the poises around and setting the beam in motion with 
my fingers, I let the scale be out of balance on zero and out of balance enough on the total weight, so that when I had a 50 pound weight placed on the scale, I made the beam operate so that it looked like the 50 pounds weighed nothing, letting this witness be satisfied, by closely watching me, that the zero balance and loaded balance seemed in each case correct. In order to be able to detect bad practices you should know how they work.

All of the foregoing is to sliow you that unguarded weighing of livestock is most likely a very costly thing to the American producer.

This paper, however, is chiefly to tell you how we are trying with very limited means to curb this condition iu Minnesota. The Minnesota farmer produced for market $\$ 458,542,000$ worth of livestock last year-almost half a billion dollars-most of which was weighed on the hoof. If the Minnesota farmer was short weighed only 3 percent last year, his loss would be almost $\$ 14,000,000$. Talk about teapot dome scandals! However, Minnesota has pioneered quite a number of control measures on scales and weighing. Also, we produce other things besides livestock. Did you know that your Secretary, Ralph Smith, whom we know as the final and best informed authority on weights and measures control, is a native Minnesotan? In his early days, Ralph served in the Mimmesota Weights and Measures Department. Another former scale inspector from Minnesota is Charles Richard, Supervisor of Scales and Weighing of the U. S. Department of Agricultmre. Dick is also considered to be one of the best scale engineers we have. Mimmesota started out in its State scale testing program in 1885 , by taking over the weighing of grain in the terminal markets, with a bonded State weigher at each hopper scale, and with a periodic test of the scale twice a year. (By the way, the granddaddy of all State scale inspectors began his career in Mimnesota sliortly after this time. None other than our good old friend, "C. C." Neale, who also is a native Minnesota product. Charlie began as assistant scale inspector about 1890 testing State-weight hopper scales; he then remained in our State service for about 30 years, being our first head of the State Weights and Measures Department. From there, he started his illustrious career in private industry in related weights and measures work for almost another 30 years and just recently retired. Charlie, you know, has probably attended more weights and measures conferences over the country than any one.). State weighing of grain, however, was not begun as a protection to the producer but instituted as a means of control of weighing between the country elevator and the buyers in the terminal market after the farmer had sold his grain. Minmesota began the testing of railroad track scales in 1907 and is one of the few States that do test track scales. Existing records show, I believe, that the track scales in Minnesota are maintained at a greater degree of accuracy than anywhere in the country. In 1911 Charlie Neale started the Minnesota Weights and Measures Department going-one of the first States to have a State Department of Weights and Measures with bona fide State sealers.

Now coming to the point of this subject. To control the weighing of this 458 million dollars of livestock together with additional stock that finds its way into this second largest terminal stockyard in the 
country from outside the State, Minnesota has in one respect done what has not been attempted by any other State to my knowledge. By a special Livestock Weighing Law, in 1919, the weighing of all the livestock at the St. Paul Union Stock Yards at South St. Paul was taken over by the State. A bonded State weigher was assigned to each scale. The scales were required to be tested every thirty days, or once a month. The tolerance on these scales (listen carefully) is only $1 / 4$ of 1 pound per 1,000 pounds of test weights at scale capacity. This is four times as close as the commercial scales in Minnesota, eight times as fine as the average heavy-duty scale in the country. The South St. Paul stockyards has grown to be the second largest livestock market in the world, according to the amount of business that is transacted there. There was $\$ 357,000,000$ worth of livestock weighed at South St. Paul last year although it is only fifth in area in the country. The State livestock weighers and the Minmesota Weights and Measures Department are not the only ones who are of the opinion that State weighing has contributed a great deal to this market's growth. Livestock that could probably be sent more easily to other livestock centers finds its way to South St. Paul instead. 'There has been no scandal about livestock weights at this stockyards terminal about which much has been broadcast in the papers in other livestock centers. By the way, one reason why I have been talking about livestock being 3 percent short weighed, is so that you may realize that at this market, 3 percent would amount to alnost $\$ 11$,000,000 in a year. These scales could be gradually adjusted so that they would be 3 percent in error either fast or slow and I am sure that the ones who buy or sell over the scales would not know the difference. Only three persons would have to be involved to perpetrate such a steal. If you were to begin this kind of a nefarious scheme in the seven leading terminal yards in the country, it would concern only a handful of men and the take could amount to almost one-half billion dollars. A recent analysis showed us that if each draft weighed at South St. Paul were only five pounds in error, whether this error was on a single animal or a carload at once, the loss would amount yearly to over $\$ 2,000,000$.

In 1921, the United States Congress passed the Packers and Stockyards Act taking control over the weighing of livestock in all terminal or public yards over the country, but Minnesota was already doing such a good job at South St. Paul that a stipulation was provided in this act to permit Minnesota to continue to function with their State weighing program by license from the Federal Department of Agriculture.

There are 37 hoof scales operating in this market. In 1935, Minnesota enlarged its program to include the weighing and 30-day scale test, at 9 out-State buying stations and concentration points, where a daily a verage of 250 or more head are handled. 'This brought 19 more scales in this category under direct control. Two of the largest of these are the Hormel packing plant at Austin, and the Wilson packing plant at Albert Lea.

I would like to go into some detail about the procedure of this 30 day test of each scale. May I say that I am prepared to furnish records that will prove that the State-weight scales at South St. Paul 
have been, and are, the most accurately maintained group of scales in the country. This has been made possible through an unprecedented state of cooperation between a private industry and a government agency. With perfect harmony and a willingness to always work for scale perfection, the stockyards company not only is subject to the strictest test that can be made of scales, but encourage and work with the Minnesota Weights and Measures Department to keep up the high standards. 'This has been largely the result of the stockyard's good fortune in having one of the best scale engineers in the country-Mr. Joseph M. Moser, who I am sure, not only during his working day, but his off-work hours as well, has studied scale design, construction, installation, and maintenance surpassed by none other in the country. Mr. Moser, as you will see, has been somewhat of a designer of new scale adaptations.

Each monthly test is made, not with strain loads, but with actual test-weight standards, for the laws require that no scale be used to weigh more than its tested capacity. At South St. Paul there are 7,000 pounds of 50-pound test. weights, two cast-iron test-weight rollers of 4,500 pounds each and two each of 6,250 pounds, making a total application on the larger scales of almost 30,000 pounds in testweight standards so that a whole carload may be weighed at once and stay within the law. At 30,000 pounds, the scale may be no greater in errol than $71 / 2$ pounds, plus or minus. This seems unfeasible, does it not? But first, let me tell you how we keep the weighbeams sufficiently accurate. We test, or calibrate, as we say, the weighbeam separately from the scale, treating the weighbeam as a steelyard or a scale in itself where it can be tried out very carefully as a precision instrument. The scale repair shop is fitted out with a steel I beam structure on deep piers to eliminate ground vibration, where the beam is fitted to an adjustable fulcrum loop bearing, and pans are suspended from the load and tip pivots. By applying the correct amount of laboratory weight standards to the load pan, every notch of the beam can be read out separately and carefully. A correct tip ratio is carefully maintained, as is also a definite butt ratio. It is very important that the same amount of balance weights that may be needed for a particular scale be hung at either back balance pivot or tip pivot, as the scale requires. The main poise and fractional bars are maintained at the correct weight the manufacturer intended them to be, and, since the lever ratio is also so maintained, beams of the same butt ratios may be interchanged, usually without adjustments to the lever system. Repairs may be made accurately to all parts of the beam and poise. Parts may be replaced, poises resealed, and corrections made to damaged notches. The scale beams in the yards are so standardized that there are only three different styles and sizes of beams, so that by keeping three spare beams on hand no scale is shut down for repair for long, should wear or tear on beam poises or notches develop on the scales. When the weighbeam passes this careful scrutiny, it is ready for use on the scale. Every one of these scales are ideally installed on concrete foundations set on deep concrete pjers. All pits are entirely concrete, as are the scale decks. All pits are well lighted and provided with proper drainage and ample passageways to the pits. The scales are kept as clean as are any vehicle scales in the country. 
Inagine this condition in a stockyard! Believe me, the happiest year's of my life, to date, were the 13 years I personally made the monthly inspections of these scales.

The test of the scale progresses as follows: Since the average weight per draft on these scales is only 1.2 head per draft, it is very important that the scales be tested in such a manner that all notches will be checked from 50 pounds up to the maximum weighing capacity. A single scale may be subjected to the weighing of 50 calves, or it may be used to weigh only one calf. 'The ideal SR is maintained on these scales-from 1 to $1 \frac{1}{2}$ times the minimum graduation, or from 5 pounds to 8 pounds. This permits accurate weighing to the minimum graduation, and still doesn't provide a sluggish or slowly oscillating beam to unnecessarily delay the weighing. Any finer SR than one graduation only results in confusion, since you can only read the closest 5 pounds, although in most cases, since the scales are so carefully kept, an SR of 2 or 3 pounds could just as easily be maintained. An indicator is fastened to the tip of the weighbeam with a graduated scale aftixed to the trig loop. ('This indicator is also used in calibrating weighbeans in the rack.) In this manner, there is no mistaking what the amount of error might be, and the scale in this way can be read to the closest 1/4 pound. (In fact, all the heavy-duty scale inspectors in Minnesota use indicators on the beams when testing commercial scales.) The scale is then balanced to a correct zero reading. The fractional bar, or poise, is first tried, followed by an application of 100 pounds at a time up to 500 pounds in the case of 100 -pound notched beams on the main bar, and this may be to 500 pounds one month, 600 pounds second month, and 100 pounds more each month up to 1,000 pounds so that in each 6 months we maintain an accurate check of all the notches to scale capacity without making tests too tedious. When 1,000 pounds is reached and in the case of 1,000-pounds notched main beams, the weights are then increased a thousand pounds at a time until the 7,000 pounds of 50 's has been applied. From here on the test-weight rollers are applied to the weighing capacity of scale.

At any test, as soon as an error beyond tolerance is noted, since ratios at both butt and tip are known, the inspector immediately determines whether the error is caused by scale lever's or by wear and tear on notches or poises of the beam. If it is the scale lerers or foundation, corrections are made immediately. If it is the weighbeam in error, the beam is taken out, a spare beam installed, scale retested, and scale is ready for service. Seldom is a scale idle for repairs more than a few hours. Seldom when beams are changed is it necessary to make even a slight adjustment. And just think, the tolerance on these scales is only $1 / 4$ of 1 poind on each 1,000 pounds. Even gold is not weighed to a more accurate degree.

If you could personally look over our test reports you would see that there are scales that can pass this test month after month without correction, even with our tolerance. Better than that, you should be there yourself to observe how really close they are at any reading to 30,000 pounds. I remember one time not too long ago, when Mr. Christian Christensen, our present special State weight livestock scale inspector (who ranks as a supervising inspector) was unfortunately at one of the out-State stations one day, Joe Moser called me and 
begged me to come down immediately to test a scale that had been idle for several months-a sheep scale that was sorely needed that day. All that Joe had done to the scale to prepare for the test, was to put the compressed air to the lever's to remove the dust. I took with me another one of our Supervising Inspectors who had not at that time been privileged to test these scales. After I had been doing the reading to a few liundred pounds, I asked this inspector to take over while I had a cliat with. Joe. Shortly we heard the inspector talking to himself. Wonderingly we wallied closer to him to hear" lim say: "I don't believe it! I don't believe it!" The scale had shown no greater error than $1 / 2$ pound at any leading up to the scale's capacity of 20,000 pounds.

One thing has been proved. Frequent tests do not see if the scale is accurate; 30 -day tests maintain the accuracy of the scale.

Things did not run so smoothly years ago. Diversified farming of the northwest area changed the weighing of 35 years ago from mostly carload weighing, beginning in the $1920^{\prime} \mathrm{s}$, to less and less number of head per draft, so by 1930 only about 2 head per draft were weighed. (As I said before, the present ratio is 1.2 head per draft.) The commission salesmen, the buyers, and the handler's of the livestock demanded faster and faster weighing. The handling of livestock was speeded up until they were rumning in some cases 60 to 80 drafts per hour over the scale. Weighing accuracy was not hampered, since all the weighers are adept bonded State men, but with speed, the rough handling of the poises by weighers which resulted was raising havoc with the notches and pawls of the poises. Beam-notch errols were developing gradually woise and worse. Some beam poises weigh 25 pounds and it is easy to see what happens when the poise becomes a sledge hammer on the notch surface. On one scale the 1,000-pound main beam notch developed a 5 -pound error in a month. The goal that had already been achieved years before was being lost. Attempts to order a slowing up of the weighing almost resulted in Joe Moser and myself being run out of the yards by an angry mob. It would have been too costly to try to have sufficient spare beams to change every month. Several types of over-and-under indicators were tried to no avail. It was then that Joe conceived the idea of hooking up two reading heads to one scale by the use of floating levers between the extension levers and the two heads. Full automatic dial scales had been rejected in the yards, since a printed weight was required by law. Accuracy couldn't be maintained in weighing with an antomatic ticket printer dial, since too often just as the weigher pressed the button to print the weight the animals on the scale would surge and the scale would print the weight in error sometimes as much as 30 or 40 pounds. Dials equipped with automatic locking devices wouldn't work out, either, since delay while waiting for animals to remain quiet long enough to record correct weight would take possibly three to four times as long. Such loss of time would prove too costly to buyer and operator and seller alike. Joe's ingenuity and perseverance in an idea permitted him to work out a plan employing both a dial and beam on one scale, each working independently of the other and each recording the same weight. Here was something-a dial to show in which notch to set the beam poise for fine readings. A dial of 
sufficient capacity, unless employing time-delaying drop weights for the fine graduations, conld not have the required minimum graduation on livestock scales. This dial beam has not only proven to be a boon towards the saving in wear and tear to notches of beams, but has saved additional time from what had previously been used with just a weighbeam. We had found that in using beams alone, the weighers had needed an average of 7 placings of the poises before correct weight was determined. With dial and beam arrangenent the arerage number of placings of the poises for each weight has been cut to only 2. Weighers had felt that 80 drafts per hour was real hot-shot weighing. Now dial-and-beam has permitted 100 drafts and over per hour with ease. In Joe Moser's experiments he had access to another one of the best scale engineers in the country, Mr. Joseph M. Heinen, of St. Paul.

About this time additional improvement in weighbeams was employed. Beams with single-pawl poises were gradually replaced with beams with multiple-tooth-pawl poises with notches on the under side of the beam. More teeth being engaged made less wear. Some of these beams have been in use for over 15 year's without any notch error creeping in.

The dial-beam arrangement resulted in other improvements to the weighing accuracy. Like a full-automatic scale, the dial-and-beam has permitted that zero balances be checked as soon as the scale platform is empty and free without returning the beam poises to zero. Less delay incurred in rebalancing. Better conditions of zero balances kept at all times, for greater accuracy. Anyone in the scale house can easily see what the weight is without having to look closely at poises.

However, a great deal of livestock in Minnesota is sold by the farmers to some 1,000-odd livestock buyer's before it comes under the State reigher's protection in the packer stations or in the South St. Paul Terminal. At these unguarded buyer's' scales, presently, I'd venture to say is employed as much sculduggery as there is anywhere in the country. But we are taking the advice of Colliers and putting the cop back on the beat.

In these small buying stations, where we have no State weigher's, the scales are tested only once in 3 years (lack of appropriation funds for free inspection) with no supervision of the weighing. We are starting, however, a new program, offering our services to some of the better ones, and have made contracts already with over a hundred buying stations and sales pavilions for a 90-day periodic inspection. as a special, at the owner's expense. This will, by some means or other, shame most of the remaining to go along with this program. 'The publicity that the 90-day test will bring will make business drop off for those who are not inchuded. We are laving a special testing unit built for this testing alone, employing twelve 500 -pound test blocks and forty 50-pound weights. This truck will carry more test weights if needed. Usually the average country weights are less than 4,000 pounds. In this way, while testing these scales several times a year. we can do some supervising of the weighing. 
THE LAWS AND THE CASE BOOK

\section{By Mrs. Katuryn M. Schwanz, Attorney-Editor, Office of Weights and Measures, National Bureau of Standards}

Dr. Condon informed you on 'Thesclay that the National Burean of Standards is preparing two legal publications for use primarily by weights and measures officials. The first of these is the fourth revision of the Federal and State laws relating to weights and measures, and this is now in process of printing. The second, at present only in the first stages of preparation, is a case book which will include references to practically all of the weights and measures decisions of Federal and State coints of record.

The compilation of weights and measures laws cover's statutory provisions of the 48 States, the Territories and the Island possessions of the United States, and also Ferleral laws and regulations. In the case of practically every State, the session laws of 1949 have been included; this means that this edition will be quite up to date, even by the time it reaches your desks. I think it will be of interest to you to know something of the format of this new publication and the respects in which it differ's from the previous edition of 1926 .

First, the Introduction to the publication sets forth considerable historical data and includes the texts of certain joint resolutions and statutory provisions passed by the Congress with respect to standards. Because of its historical significance this material is considered more appropriately placed in the Introduction than in the United States chapter, which presents statutes currently in effect.

The text begins with the United States chapter which, of course, contains the Federal laws relating to weights and measures. Only the pertinent sections or parts of sections of these laws are included. Regulations promulgated pursuant to several of the Federal laws follow directly after the laws which they supplement.

The chapter's dealing with the States, Territories, and possessions follow the United States chapter, these being presented in alphabetical order. Each contains the text of the weights and measures laws of the jurisdiction in question.

An important addition to this publication is the inclusion, at the beginning of each chapter of the text, of a table of contents. Each table lists, in the order of their presentation in the text which follows, the main citations and the section numbers and titles, and includes page references. An examination of the table of contents for a particular State will give the reader a comprehensive picture of the legislation of that State, and will show clearly the relation between the various principal enactments and the field coveled by each. Moreover, if one is interested only in locating a requirement of that particular State, the table of contents may give quicker results than the general topical index for the entire publication.

The publication is concluded with a topical or subject index. This will be one of the most important parts of the volume, for it will enable the reader to locate all references in the entire text to any particular subject. Material will be indexed under various key words; that is, it will not only be indexed but cross-indexed. References will include page numbers and, in addition, the name of the State or other jurisdiction in each case; it is believed that the latter information will be 
especially useful. Thus the index will not only be a tool for locating the statutory texts but will of itself present a summary of the extent to which a particular subject has been treated legislatively.

In the text of the laws there are provided complete code or sessionlaw citations with headings descriptive of the various acts. The descriptive heading takes the form either of the official short title of the act as enacted by the legislature or of one devised by us when there is no official short title. Each section is identified by number and title. The section titles have been retained as they appear in the various State codes so long as they reflect the contents of the sections with reasonable accuracy and clarity, but wherever it was deemed necessary to change a title to make it informative we have not hesitated to do so. Citations, section numbers, and section titles will appear in bold-faced type to make them stand out from the regular text. This will facilitate the location of desired material and the reading of the text. For the text itself this will be printed two columns to the page, and a type style has been selected which it is believed will make the text easy to read, particularly in the long paragraphs so frequently found in statutory material.

Frequently a law will contain many sections, ruming for sereral printed pages. If the citation is given only once, at the beginning of the law, the reader of a particular section may have to search many pages to find the citation. An innoration in the new publication will overcome this difficulty by repeating the citation at the top of the lefthand page whenever the citation is continued from a preceding page. "Thus, at whatever point the volume may be opened, it will not be necessary to turn a page to locate a citation-the citation for any text in view will always appear on one of the exposed pages.

So much for the statutes. As for the case book, though all of our plans have not been made concelning the method of presentation, it has been decided to report the court decisions in digest form rather than in full text.

In planning this book, our primary aim is to make it of utmost utility to weights and measures officials. At the same time, we have kept in mind the needs of other readers-lawyers, courts, and representatives of business interests-and have tried to provide for the inchusion of material and a form of presentation to meet those needs.

So far, we know of about 600 weights and measures cases and we plan to include most of them in one way or another, so that there will be readily at hand in a single rolume essentially all of the case law on the subject of weights and measures. All of the significant decisions will be digested and each decision will be preceded by the full name of the case, the name of the court, the date of decision, and a complete citation to the official Report in which it appears. The other decisions, of lesser significance, will be reported in abbreviated digests or by mere citation. Comments, footnotes, and crossreferences will be included throughout as needed to coordinate legal principles.

It is plammed to arrange the book in chapters and subdivisions of chapters. Each chapter will deal with some general topic of weights and measures law, such as, perhaps, Regulatory Power, 'The Weights and Measures Official, Inspection and Sealing, False Weights and Measures, Penalties, Criminal Prosecutions, Packaged Commodities, 
Public Weighing, and the like. As an example of chapter subdivision, the chapter titled "Public Weighing", for instance, might very well have under it a main subdivision called "Municipal Ordinances, Validity and Effect," and under this may come several subjects. One such subject might be "Commodities Sold in Load Lots;" all of the cases involving the validity of municipal ordinances regulating commodities sold in load lots would be presented here.

A case may be referred to in several chapters of the book; this would happen when a case decides several different points of law concerning weights and measures. Whenever one angle of such a case is discusser, there will be included a cross-reference to the other topics mnder which other points of law covered by that decision are discussed.

As to the indexing system, there will be a table of contents at the beginning of the publication, and also a table of cases, alphabetical by perhaps both plaintiff's and defendant's name. There may be another case table alphabetical by States. There will be a topical index, complete and detailed, perhaps indicating jurisdictions. Detailed plans have not been completed for this indexing system, but our aim will be, by means of effective indexing, to guide the reader quickly and easily to the cases covering the legal principles which he is interested in exploring.

Suggestions from weights and measures officials regarding the case book will be welcomed. If any of you has knowledge of very recent cases of record in your jurisdiction, it will be helpful if you will report them to us.

\section{REPORT OF THE NATIONAL CONFERENCE COMMITTEE ON METHODS OF SALE OF COMMODITIES, PRESENTED BY J. F. BLICKLEY, CHAIR- MAN, AND DISCUSSION THEREON}

Preamble.-Your Committee on Methods of Sale of Commodities respectfully submits its report to the Conference for consideration.

The 1940 Conference created the Methods of Sale of Commodities Committee to study and recommend to the Conference the best method of sale for commodities which informs the purchaser what is actually received for the amount of money spent, and which enables a comparison to be made with prices of competitive commodities. Proper method of sale protects the consumer's interest and decreases the risk of unfair competition and practices.

By careful study and deliberation previous committees have recommended for the consideration of this body the best method of sale for most commodities where a problem of this nature existed. .Some items still need solution; when brought to the attention of the committee they are highly technical and controversial, and it is very difficult to reach decisions which will be satisfactory to all concerned.

Long honr's have been spent and many personal inconveniences were encountered by the members of this Committee since it was created. We believe they were worth while; results obtained have been beneficial to all concerned.

Manufacturers and manufacturers' associations whose commodities were brought to the attention of the Committee thus far are satisfied with the fairness and consideration the Committee afforded them in arriving at solutions even though they did not get all they asked for. The Committee in many cases also changed their original conception 
after witnessing problems encountered in industry. 'The only satisfaction both sides of the conference table achieved was a better understanding of the problems confronting each other. Closer relationship has been established; instead of being cousins far removed we are now brother's in a common canse exerting every ounce of strength at our command to furnish the ingenuity to arrive at a solution beneficial to all.

Due to misunderstandings that have been evidenced in the past, previous chairmen found it necessary to clarify what the purposes and functions of this Committee are. As some misunderstanding still exists, I find it incumbent to again attempt clarification. The Committee was created to study and decide upon for recommendation to this assembly, the best method of sale for all commodities, and to promote adoption of methods recommended and uniform enforcement in all State jurisdictions. It is not the purpose of this Committee to impose or attempt to impose any legislation, rules, or regulations on any jurisdiction; the Committee only acts in an advisory capacity and recommends for adoption its findings which are worked out on a cooperative basis with industry, with only one purpose in vier, uniformity in procedure, which will, beyond a doubt, 1'esult in elimination of harassing restrictions in industry and better consumer protection. If recommendations are adopted it is in the discretion of the officials of each jurisdiction to adopt, ignore, modify, or add to the recommendalion as coming out of this Conference; they must act and be governed by the statutes that are enacted and in effect in their jurisdictions.

Since the last Conference the following items were referred to the Committee for consideration:

1. Wiping Cloths.-This was covered by Item 7 of the Committee's report to the Conference in 1949 . The terms of the recommendation at that time, which were adopted by the Conference, are as follows:

Wiping Cloths (Washed and Unwashed)-should be sold by net weight and when put up in bales, cartons, or other containers, the net quantity of the contents should be plainly and conspicuously marked on the outside of the package.

Representatives from the Sanitary Institute of America, representing the wiping-cloth industry, were of the opinion that the above recommendation was adopted upon the basis of incomplete factual information and that if the Conference had been in full possession of all revelant facts, the recommendations would not have been adopted. They requested that the recommendation be reconsidered and rescinded, and they submitted a rather lengthy brief stating their reasons why the recommendation should be rescinded, at the same time requesting that the Committee open the subject and grant a rehearing on this item with a representative committee of the Sanitary Institute of America. The Committee finally agreed to grant a rehearing, which was held in Chicago on December 6, 1949.

In the petition submitted by the Sanitary Institute of America in which they requested that our recommendation of net-weight sales be rescinded, they based their plea for this request on custom, trade practice, competition with other commodities that are used for the same purpose, and unfair competition if the product is produced in States where no weights and measures laws are in existence. After careful study and deliberation your Committee decided that the recommendation as adopted by the 1949 Conference should stand as approved. 
Your Committee and the committee representing the Sanitary Institute of America then agreed that the proper method of sale of wiping cloths should be on a net-weight basis and the recommendation adopted by the 1949 Nitional Conference on Weights and Measures be put in effect.

In order to meet the net-weight recommendation requirements and not impose any hardship on the industry as a whole, the following resolution was submitted by them with a recommendation that our conmittee favorably report same to the 1950 Conference on Weights and Measures for adoption:

Resolved, That application of the net-weight principle for the wiping-cloth industry shall be postponed to January 1. 1952, as the effective date for enforcement in order to educate all concerned that wiping materials shall be sold by net weight.

Resolved, The term "wiping material" shall be construed to mean all textiles, washed and unwashed, new and/or old, such as mill rags, mill ends, remnants, cheesecloth, cotton thread, shoddy, clippings, machined cotton and wool waste, discarded garments, discarded household textiles, raw cotton and/or any other material or thing used in the mannfacture of wiping material.

Some competitor's in the wiping-cloth industry are of the opinion that their products do not come under the recommendation for the reason that the recommendation specifically stated "wiping clothswashed and unwashed." It was not the original intention of the Committee to exclude the many various types of wiping cloths from the recommendation; it was intended to cover all kinds and types of wiping cloths.

The members of this Committee agreed that further defining of the term "wiping cloth" was a sincere and fair request and by defining the tel'm in this manner it would involve all materials that are being used at the present time.

The Committee also agreed that an extension of time should be granted before actual enforcement begins in order that the industry can educate all concerned and make changes that are necessary to put the recommendation into effect; however, the Committee was in disagreement as to the effective date, January 1,1952 , requested, the actual effective date to be agreed 11 pon by the entire Committee at a meeting which will be held in Washington prior to the convening of the National Conference.

The Committee, therefore, proposes and recommends for adoption that the 1949 recommendation of the Committee relative to "Wiping cloths (washed and unwashed)" be deleted, and that in its stead the following recommendation, further defining this item, be substituted:

Wiping Material.-Wiping material shall be construed to mean all textiles, washed and unwashed, new and/or old, such as mill rags, mill ends, remnants, cheesecloth. cotton thread waste, shoddy, clippings, machined cotton and wool waste, discarded garments, discarded household textiles, and/or any other material or thing used in the mannfacture of wiping material, and shall be sold by net weight; when put up in bales, cartons, or other containels, the net quantity of the contents should be plainly and conspicuously marked on the outside of the package.

Mr. Burchuer. I believe that it will be in order at this time for the Conference to act upon the Committee's recommendation relative to wiping material.

(It was moved and seconded that the recommendation of the Committee be adopted.) 
Mr. J. T. Kennedr. When was that particular code adopted and when was the industry notified?

Mr. Buickley. 'The industry has known of this change since last December" except as follows: The definition originally included "cotton thread." That was an error" we should have said "cotton thread waste." Originally the definition included "raw cotton"; these words were eliminated because we find that raw cotton is never used as wiping material. These changes in the wording were made at our meeting here on Monday.

Mr. Baucon. As a nember of the Committee, I should like to explain my view on this question. First, practically every State in the Union has a net-reight law, which, in substance, means that whenever the term "weight" is used it means "net reight." Second, it is seldom, if ever, that wiping cloths are sold or bought except in package form, so this commodity falls into the category of package goods. Third, the National Conference on Weights and Measures has already gone on record as recommending that any commodity in package form be labeled to show its net content. Fourth, this subject has been before this Committee for three years, and recommendations on the method of sale of this commodity were adopted at the last National Conference. Fifth, no new material or facts have been presented, which to my way of thinking, justify a reconsideration of our action last year. Therefore, I must vote "No."

Mr. WITT. I move that the definition of "wiping material" as recommended by the Committee be amended to read. "WViping cloths. washed and nuwashed, and cotton waste." These words are selfdefining and cover the entire field of wiping material.

$M_{R}$. Blickley. Perhaps I can clarify the situation Mr. Witt, so that you will withdraw your motion. Our proposed definition includes the words "or any other material or thing used in the manufacture of wiping material." That covers practically everything; nothing is missed.

The Chamran. Do you consent to that, Mr. Witt?

Mr. WitT. I consent.

(The question was taken and the motion was agreed to, thus arlopting the definition of wiping material as recommended by the Committee.)

Mr. Blickley (reading) :

The Committee also recommends that an extension of time be granted in order that the entire industry can make the necessary changes to put the net-weight recommendation into effect. 'The Conmittee further proposes and recommends for adoption the following:

The effective date of enforcement of the net-weight declaration on wiping material shall be January 1, 1951.

(It was moved and seconded that the recommendation of the Committee be adopted.)

Mr. WIrr. Last year this Conference adopted a lecommendation that wiping cloths, washed and unwashed, be sold on a net-weight basis. Accepting this recommendation at its face value, I went back to my own local jurisdiction, the City of Milwaukee, and recommended that our Purchasing Board and the Milwaukee School Board buv this commodity on a net-weight basis. The local dealers immediately objected to this proposal and stated that it would work a hardship 
on them, and that they might refuse to bid for city business on this basis.

When it was pointed out to the Purchasing Board and the dealers that my own recommendation was based on the oflicial action of the National Conference on Weights and Measures, the Purchasing Board insisted that wiping cloths be purchased on a net-weight basis. Further, the dealers completely reversed themselves and agreed that net-weight sale was practical, and that it should be enforced on a net-weight basis. In other words, it was the prestige of this National Conference which effected the very desirable change in the method of sale of this commodity in the City of Milwaukee.

Shortly after this, the recommendation of the National Conference on Weights and Measures with respect to the sale of wiping cloths was published in the oflicial organ of the National Institute of Governinental Purcliasing, and given wide distribution. This organization has a membership of over 2,000 purchasing agents at all levels of governmental purchasing-local, State, and Federal.

As a result of this wide dissemination of the Conference action last year, there are many purchasing agents who today are buying wiping cloths on a net-rveight basis. There seems to be small need for additional time to educate the industry. I think it is pertinent to report to the Conference that the City of Chicago is one of the cities which at the present time is purchasing wiping cloths on a net-weight basis. As you know, Chicago is the headquarters for the Sanitary Institute of America, and the Institute certainly is aware of the fact that many of its nembers are selling wiping cloths on a net-weight basis to governmental procurement agents.

The Federal Bureau of Supply is at the present time purchasing this commodity on a net-reight basis. I am quite sure that the Navy Department, one of the largest users, is also purchasing wiping clothis on a net-weight basis in accordance with the new consolidated Federal Government specifications. This method of sale is working no hardship on the bidders and vendors of wiping cloths, and all of them are on the same competitive basis. If the Conference this year were to tamper with last year's considered recommendation concerning wiping cloths, this would not only nullify the progress which has been made, but would seriously damage the prestige of the National Conference itself. There might be doubt as to whether or not the Conference meant what it said and did in its deliberations and actions. This vacillating shifting back and forth of the Conference position would adversely affect the confidence and respect which this Conference has enjoyed for many years.

For the reasons cited, I feel that the Conference could very properly consider the advisability of placing on the table the Committee's recommendation of this year with respect to the sale of wiping cloths.

Mr. J. T. Kennedr. I mas present during a part of the meeting of this Committee the other day. I feel that what was said at that meeting by the representatives of the wiping-cloth industry may have some merit. When industry representatives attend meetings of committees of this Conference I fear that some of them-not all-go home hoping that the following year they can come back and protest the action taken the preceding year. 
I do not feel as Mr. Witt does, and I am sorry to say that I do not feel as the Committee does. I move that the original motion on the adoption of the Committee's recommendation be amended to provide that the effective date of the recommendation will be July 1,1950 instead of January 1, 1951. I believe that the industry has had time to get its house in order, and from my observations the other day, and with my apologies to those gentlemen, I do not believe that they desire to do so.

(The motion of Mr. Kennedy was seconded.)

Mr. Rogers. In fairness to the industry I think we should clarify what was done. 'The Committee did not agree with the industry proposal for a 1952 date. That amount of time was considered to be entirely too long. I said that they had already been placed under notice 6 months ago and that they knew what was going to happen, but they said that there is still much educating to be done in the mills and elsewhere. Some of them do not want net-weight sales at all. So the Committee decided to give them until January 1, 1951. This thing has been going on for 75 or 100 years, so this delaying action for 6 months will not hurt anyone. It is regrettable, of course, that we seem to have broken faith with $\mathrm{Mr}$. Witt and maybe one or two other jurisdictions that have already regulated, but I do not think that we shall lose any prestige by maintaining our policy of always being as fair as we can be to industry, so that they cannot say that we arbitrarily take action that hurts somebody.

'The Chaminan. Mr. Rogers, will you accept Mr. Kennedy's amendment to your motion?

Mr. Rogeus. I must decline to accept the amendment for the reasons I have given.

Mr. Baucon. The reason for my objection is that we would be recommending a violation of practically every law that we have on our statute books affecting net weight. I appreciate what Mr. Rogers has said regarding fairness to an industry, but $I$ do not think that we can properly recommend a violation of our statutes.

The Chamman. The question is on the amendment of the recommendation of the Committee by substituting the date "July 1, 1950" for the date "January 1, 1951". Are you ready for the question?

(A voice vote was taken, and the Chair was in doubt as to the result. A show of hands was called for by the Chairman, and the result was still in doubt. The Chairman then directed that a teller vote be had, and that those in favor of the amendment first pass by the Secretary to be counted. The Secretary reported to the Chairman, and the Chaiman announced, that the count was 44 in favor of the motion. The Chairnian their directed that those opposed to the amendment pass by the Secretary to be counted; the number opposed appearing to be small, the Chairman requested those opposed merely to stand. After the count the Chairman announced that 20 were opposed to the motion, and that accordingly the motion to amend the Committee recommendation by substituting "July 1,1950 " for "January 1,1951 " was adopted.

It was then moved and seconded that the Committee recommendation as amended be adopted, the question was taken, and the motion was agreed to. This action resulted in the adoption by the Conference of the following: "The effective date of enforcement of the net-weight declaration on wiping material shall be July 1, 1950".) 
Mr. Brickiter (reading) :

2. Liqueficd Gases (Butane, Propane, etc.) for household use. This was covered by Item 3 of the Committee's report to the Conference in 1947. The terms of the recommendation at that time, which were adopted by the Conference, are as follows:

Liquefied Gases should be metered and sold by cubic feet.

The proper and best method of sale for this commority is beyond a doubt the most diflicult problem ever presented to this Committee for decision. It is the most controversial subject weights and measures officials have faced in the last decade. The discussions at the 1949 Conference have convinced the industry and weights and measures officials that a solution must be made as soon as possible.

A sub-committee of the Methods of Sale of Commodities Committee and a committee of the Liquefied Petroleum Gas Association have made a sincere and honest effort to arrive at a solution, several lengthy conferences were held, and a deadlock developed as to the proper method of sale. [There is no Committee deadlock at the present time.]

At the last meeting of the subcommittee and the committee representing the Liquefied Petroleum Gas Association, the following proposal was submitted by them with a request that our Committee submit same for tentative adoption and to remain in effect until the next annual Conference in order that further study be made of the liquefied petroleum gas problem with the assurance that steps would be taken immediately to conform to the proposed temporary requirements.

Liquefied petroleum gases to be sold and distributed by weight, vapor volume, liquid volume or by specially defined units as follows:

(a) By weight:

1. Containers used where gas content is sold by package weight must have the tare weight plainly marked on the container or on permanently attached appurtenances, and the net contents plainly and conspicuously marked on the container or on a tag or other type of label firmly attached thereto. (Tare weight is the weight of the container, valve and other permanent attachment but does not inchule valve protecting cap.)

2. When liquefied petroleum gas is sold by weight, and is expressed, in units other than pounds for billing purposes, the delivery ticket or invoice shall show the equivalent of such units in pounds.

3. When measured by weight, variations at the rate of one pound per one hundred pounds over and one pound per one hundred pounds under the specified net weight of the container are permitted in individual containers, but the average weight of not less than twelve containers shall not be less than the marked net weight of the container.

(b) By vapor volume:

1. All meters shall be of a type approved by the authority having jurisdiction.

2. The meters shall measure in cubic feet, however, may register in cubic feet or other recognized unit. The dial on new meters shall be marked by the manufacturer with such a unit.

3. When liquefied petroleum gas is sold by vapor volume and is expressed in units other than cubic feet for billing purposes, the invoice shall show the equivalent of such units in cubic feet.

4. Each metel" dial shall be equipped with a cubic foot test indicator for checking accuracy.

5 . The meter or dial shall be marked with a cubic footage equivalent to the designated unit of such meter.

(c) By liquid volume:

1. When liquefied petroleum gas is sold by liquid measure only devices as approved by the authority having jurisdiction shall be used for such measurement. 
2. When measured by meter, the meter and pertinent equipment must be such as to accurately assure liquid measurement whthin plus or minus 1 percent.

3. Where liquefied petrolem gas is sold by liquid volume and is expressed in units otler than standard United States gallons of two hundred thirty-one cubic inches for billing purposes, the invoice shall show the equivalent of such unit in gallows.

A brief was submitted setting forth the reasons why their proposals should be given consideration. Your committee is of the opinion that you should be acquainted with these leasons, which are as follows, somewhat briefed:

Our Industry Committee is most conscious of the magnitude of the problents involved in our sincere effort to comply with the required standards with respect to the sale of liquefied petroleum gas commodities. This Committee is fully conscious of the many instances of unethical sales of liquefied petroleum gas commodities and agrees with all concerned in the thought that unethical sales shoul be corrected immediately.

However, in the opinion of this Industry Committee the precentage of unethical sales is small on a nation-wide basis and this Committee is primarily concerned with the hope that the industry nationally will not be penalized in its ethical, honest, and sincere marketing programs because of the few instances of unethical marketing operations. The Industry Committee feels that your Committee should be acquainted with the magnitude aud number of user accounts and the volume of business that is being handled as of today in the liquefied petroleum gas industry. For the sake of comparison there are approximately eight million users of natural gas in the United States. As of the end of the year 1949 it is estimated (and this Industry Committee concur's) that there are $\mathbf{6 . 5 0 0 , 0 0 0}$ homes enjoying the use of liquefied petroleum gas service in farm and suburban homes beyond the gas unains. Included in the domestic figures are requirements for irrigation pumping, tractor fuel, weed and insect pest control, chicken brooding and fuel sold by domestic distributors to be used for industrial purposes, internal combustion engines, and for manufacturing purposes. There are tlousands of trucks and busses on the highway using liquefied petroleum gas. there is considerable interest nationally on this subject, and a continning demand exists for liquefied petroleum gas fuel for heavy-(luty engines and mining equipment. It is estimated that the total volume of liquefied petroleum gas marketed in the United States in 1945 was $2,725,000,000$ gallous which represents an increase of $81 / 2$ percent over the volume sold in 1948.

As was stated in the recent joint Committee mecting in January the Industry Committee agrees with the Method of Sale of Commodities Sub-Committee that had such a conference been planned when this industry was new in the 1920's that we would not be faced with the problems of standardization in units of measurement. Perlaps a review of the competitive fuel marketing problems at that time will explain the origin of many of the problems that we lave today. In the Industry's beginning the cost of liquefied petroleum gas was terrificaliv high on a package basis. Marketers in the industry searched domestic competitive fuel utilization fields, namely, electricity and city gas companies, fol an approach to a competitive marketing procedure in this industry. One of the handicaps the industry faced then and still faces is the high thermal Btu content of liquefied petroleun gas on a cubic-foot basis rersus the relatively low thermal Btu basis of gas narketed hy city gas companies. In the case of the city gas manufacturing companies, a nationally common rate for 500 Btu gas in the 1920's approximated $\$ 1$ per thousand culoic feet or appoximately 5,000 Btu for 1 cent. In the case of the electric companies, 1 kilowatt in the $1920^{\circ} \mathrm{s}$ approximated 5 cents for an equivalent of about 3,400 Btu or approximately 800 Btu for 1 cent. These two basic competitive quantities of thermal value were used in the beginning of this industry as a pattern to slow the thermal cost of liquefied petroleum gas in small thermal quantities at about the same cost. To illustrate the industry's thinling based on competitive fuel marketing the industry in the twenties sold liquefied petroleum gas at about 20 ceuts per pound. A pound contains about 21,000 Btu aud thus the industry could show competitively that $1,000 \mathrm{Btu}$ cost about 1 cent with liquefied petrolem ans which approached or equaled the cost of similar quantities of licating sold by electric 
companies or gas manufacturing companies. The above accounts for the many units being marketed and being measured in the industry today.

Also in the 1920's many large gas manufacturing companies in practically every State in the United States adopted a unit of measurement other than cubic feet tor standardization purposes which is today still in effect. This unit is called the therm which is $100,000 \mathrm{Btu}$ and $1 / 10$ of a therm is called a decitherm, which is 10,000 Btu. Also in the twenties several large liquefied petroleum gas distributors copied this new method of marketing and this method is still in effect today.

At some point during the tremendous glowth of the liqquefied petroleum gas industry the Bureau of Standards adopted the units of measurement of which this Industry Committee is fully conscious; namely, that all colnmodities must be sold by the pound, cubic toot, or gallon, and this Industry Committee's problem today is to attempt to recommend changes in the liquefied petroleum gas industry marketing to conform as near as possible to these new requirements standards. This Industry Committee sees no reason why we cannot conform to your SubCommittee's request in the marketing of packaging equipment and this Industry Committee agrees to the net weight markings you have suggested as a requirement. This Industry Committee concurs with your suggestions with respect to the measurement of liquefied petroleum gas liquids and will appreciate the privilege of cooperating with your Committee in having ethical measuring devices approved by the authorities having jurisdiction. The liquefied petroleum gas industry's problem in measuring liquefied petroleum gas liquid to date involves three large considerations-

1. Accurate liquid displacement metering equipment has only been recently made available.

2. Liquefied petroleun gas exerts its own pressure at normal atmospheric conditions in the United States and for that reason the Industry has followed the I. C. C.'s approved requirements of using an internal liquid level gaging device for accurate measurement in bulk consumer containers as well as I. C. C. liquefied petroleum gas tank car container's.

3. Unless liquid displacement meters are properly installed with respect to maintaining the liquid meter full at all times during the transfer of liquid they do not read accurately, which is not desirable to all concerned.

The above are the three problems which need considerable study to assure accuracy on consumer purchases.

The biggest problem this Industry Committee has is in trying to satisfy the Weights and Measures group on the subject of vapor metering. First of all this Industry has over $1,100,000$ liquefied petroleum gas meters now in consumer service. The cost to change these meters is more than sufficient to put out of business the distributors using the same. Second, because of the magnitude and number of consumers accounts using meters and the present accepted methods of registering the liquefied petroleum gas units now being used in other than cubic feet, the cost of replacing automatic-billing equipment could also place a serious burden on many distributors of liquefied petroleum gas. Third, to change overnight from existing types of liquefied petroleum vapor meters to meters that measure and register in cubic feet would cause much confusion and inaccuracy in meter reading and billing for years to come. This Industry Committee having the above thoughts in mind with respect to acceptable vapor meter registering believes that the suggested revision on the subject of vapor metering might be acceptable if given a trial period for observation. This Industry Committee has attempted to study the variation from the present Bureau of Standards requirements in sales commodity measuring and finds the following:

There are many city gas and water companies who meter measure and bill to consumers city water on a cubic-foot basis. (A Bridgeport, Conn., Hydraulic Company invoice was exhibited and several other cases cited.)

It would consume too much time on this program to discuss all details of the brief submitted; having received copies of this tentative leport it is assumed you have carefully studied and considered its contents. Except for some few changes the proposals as submitted by the Liquefied Petroleum Gas Association constitute the present 
method of sale. Weighing or measuring devices would continue to convert the recognized standard units of weight or measure to the many various units and terms of sale being used at the present time.

Because of the highly controversial nature of this subject, the subcommittee members were of the opinion, and decided, that the entire Committee should decide if the proposals as submitted should be recommended for adoption. The Committee is in disagreement in accepting the proposals of the Liquefied Petroleum Gas Association as our recommendation to the Conference for adoption. Surrender of legal and official standard units of weight and measure were the main objections to the proposals.

Your Committee has made a sincere effort to solve this highly controversial problem. Every effort will be made until it is called up at the Conference to have the solution and recommend the proper method of sale for this commodity.

Being convinced by facts presented that it is unfair and restrictive to confine the sale of liquefied petroleum gas through a volumetric meter to a cubic-foot basis, the Committee proposes and recommends for your consideration that Item 3 of the Committee's report to the Conference in 1947, which read "Liquefied Gases (Butane, Propane, etc.) for household use: Should be metered and sold by cubic feet," be withdrawn.

(It was moved and seconded that the 1947 action of the Conference in adopting Item 3 of the Committee's rejort for that year be rescinded, the question was taken, and the motion was agreed to.)

Mr. Brtckler. In its tentative report, the Committee made a reconmendation for your consideration, as a substitute for the recommendation which has now been rescinded. After several meetings which the Committee has held during the past few days it has been decided to withdraw the recommendation included in the tentative report. [Reading:]

The Committee now proposes and recommends for your consideration and adoption, the following:

Liquefied Petroleum Gas shall be sold.or offered for sale by avoildupois weight, liquid measure, or cubic feet: Provided, however, That nothing herein shall be interpreted so as to prohibit the sale of Liquefied Petroleum Gas hy other units, lecognized and/or apploved by the authority having jul'isdiction, if the meter or scale and the invoice clearly indicate to the consumer the equivalent of such unit il pounds and/or fractions thereof.

When sold or offered for sale by weight, variations at the rate of 1 pound per 100 pounds under the specified net weight of the container are permitted in individual containers, but the average weight of not less than twelve containers shall not be less than the marked net weight of the container.

Containers used where gas content is sold by package weight must have the tare weight plainly marked on the container or on permanently attached appn:tenances, and the net contents plainly and conspicuously marked on the container or on a tag or other type of label firmly attached thereto. (Tare weight is the weight of the container, valve, and other pelmanent attachments, but does not include the ralve-protecting cap.)

All meters shall be of a type approved by the a uthority having jurisdiction.

Each vapor meter dial shall be eqnipped with a cubic-foot test indicator for checking accuracy. 
When liquefied petroleum gas is sold by liquid measure, only devices as approved by the authority having jurisdiction shall be used for such measurement.

When measured by meter, the meter and pertinent equipment must be such as to assure accurate liquid measulement within plus or minus 1 percent.

\author{
J. F. BLickley, chairman, \\ R. S. ACKERMAN, \\ C. D. BAUCOM, \\ J. A. BOYLE, \\ J. G. Rogers, \\ Committee on Methods of Sales of Commodities.
}

Mr. Burckinx. Mr. L. R. Roper, the other member of the Committee, was not present and did not sign the report, but I have tentative authority from Mr. Roper to go along with the proceedings of the Committee.

(It was moved and seconded that the recommendation of the Committee relative to liquefied petroleum gas be adopted, the question was taken, and the motion was agreed to.)

(At this point, at 4:40 p. m., the Conference adjourned, to reconvene at $9: 30$ a. m. Friday, May 26.) 


\section{SIXTH SESSION-MORNING OF FRIDAY, MAY 26, 1950}

(The Conference reassembled at 9:35 a. m., J. E. Brenton, Vice President, mesiding.)

\section{OPEN FORUM}

The Champan. 'The program this morning provides for the discussion of a variety of topics. Each topic will be introduced by a discussion leader, and the topic will then be open for discussion from the floor. 'The discussions should be kept within the scope of the particular topic before the Conference at the time.

INCREASING THE VALUE OF THE NATIONAL CONFERENCE TO WEIGHTS AND MEASURES OFFICIALS-R. W. SMITH, NATIONAL BUREAU OF STANDARDS

I speak to you in my capacity as Secretary of the National Conference on Weights and Measures. 'The purpose of this discussion is not to invite commendatory comments from anyone. We should like to have constructive suggestions for the improvement of our Conference programs, if you have any such suggestions to offer. If there are things that you do not like about the Conference, you are invited to make a brief statement to that effect, and this will go into the record and will be given due consideration in making the plans for future meetings. If there are some things which you think we should do which we are not doing, we should like to have your suggestions for the guidance of the Executive Committee and the Secretary.

In other words, we want your help. We want to know whether or not the Conference is doing for you what you want it to do. We want to know in what respects we can do a better job.

The Criarrman. Gentlemen, if you have any suggestions, as I am sure you must have, now is the time to present them.

(There was no response to the invitation.)

The Secrerarx. Gentlemen, I sincerely hope that we may receive suggestions from you from time to time. 'The Executive Committee needs your help, because we want to give you a Conference next year that is as good as we know how to make it.

THE TESTING OF WHEEL-LOAD WEIGHERS-V. D. CAMPBELL, OHIO

In 1941 the Ohio Highway Patrol purchased some wheel-load weighers and asked us to work out a program for checking and sealing these devices. The suggestion was made that they purchase the necessary test weights, in view of the fact that the Department of $1 \mathrm{gricul}$ ture did not have sufficient funds for this. 'They also said they had no money. So we had to find an "out."

The College of Engineering, Ohio State University, discouraged the use of hydraulic testing machines, and suggested the use of a screw-type testing machine. The Highway Department had a testing laboratory and a testing machine which we thought would meet our needs. All of this occur'ed, of course, prior to the issnance of National 
Bureau of Standards Handbook H37, which, as you recall, deals with the testing of weighing devices.

Our first experiments with the use of this machine were unsatisfactory because of a side thrust that prevented the full force of the machine from acting upon the weigher platform. However, the engineers of the laboratory designed and built a device to overcome this difficulty. We nsed this method of testing, then, for several years and were well satisfied with it because (1) the machine could be read to within 10 pounds, (2) each value mark on the wheel-load weigher could be checked, (3) the accuracy of the machine was 1 percent while the maintenance tolerance for such weighers was 5 percent, and (4) the Highway Patrol allowed 1,000 pounds overweight before prosecution for overweight. So we thought we were pretty safe with that method.

In 1949, the Ohio Legislature saw fit to amend the highway loadcontrol laws in such a way as to eliminate this 1,000-pound "tolerance" and made the amount of fine dependent upon the amount of overload. For example, an overload of over 2,000 pounds but less than 5,000 pounds carries a $\$ 25$ fine, plus an additional one dollar fine for each 100 pounds of overload. As the overload increases, the penalty increases, until jail sentences occur.

This development caused both the Highway Patrol and ourselves to get together again, in order to see that the wheel-load weighers to be used were accurate. Still there was no money for test weights, which, of course, we would have preferred. The following program was then set up:

(1) Each wheel-load weigher was to be checked twice a year by the Testing Laboratory with the testing machine. The sealers were to witness the test, verify the results, and seal the device if within tolerance.

(2) A copy of the test, which showed the amount of variation from the load placed upon the device by the testing machine, was to be attached to the lid of the box containing the device. In this way, a patrolman could apply these variations as correction factors. Since the testing machine was within 1 percent accuracy, wheel-load weigher readings, properly corrected, would tend to come close to this same accuracy.

(3) In event that there was any question, either by the patrolman or a trucker, as to the accuracy of any device, it was to be brought back to the laboratory for testing.

(4) County and city sealers were cautioned not to try to test these devices because they did not have sufficient equipment.

At the Ohio. Weights and Measules Conference last December, a forum discussion on this subject was held, at which a representative of the Highway Patrol participated. Again the question of the validity of our testing procedure was raised. Our good friend Bill Bussey took some exceptions. So it was desirable, not only from our point of view, but also that of the State Patrol and the Testing I aboratory, to determine whether or not we were safe in our testing procedure. I mean by that, could we defend our procedure in court, if necessary. While the use of the testing machine was a convenient and fairly rapid means of testing, we didn't want to use it unless it proved to be satisfactory. Hence, we tried this experiment: 
(1) Two wheel-load weighers were brought from the field and tested by the laboratory. We did this to see whether or not there were any rariations from the previous tests which had occurred several months before. The results showed that the wheel-load weighers were as accurate as when tested previously. Errors ran from 0 to 1.25 percent.

(2) These same wheel-load weighers were then checked in accordance with the test described in NBS Handbook H37. The errors ran from 0.15 percent to 0.29 percent.

The two tests differed in this respect: The test by the testing machine covered the complete lange of the weigher, while the H37 test covered the range from 10,040 pounds to 18,840 pounds with eleven different loads. By the use of the testing machine, each weigher was tested separately. By the H37 method, the two were used as a pair, and the individual readings added, in order to compare with the scale readings.

To supplement our own thoughts and experiences along this line, I wrote to twelve different jurisdictions for some data. 'This was iu line with a suggestion from Mr. Smith. Mr. E. E. Powell, Manager, Loadometer Department of Black and Decker, was also invited to send in any constructive information. The response was excellenteach of the twelve jurisdictions replied; and Mr. Powell not only sent some data, but is here in person to assist with this Forum. With Ohio included, I have data, then, from thirteen jurisdictions. A summary shows the following:

(1) Out of eleven jurisdictions that check or have checked wheelload weighers, seven use or used the method described in Handbook H37, three use or used the screw-type testing machine method, and one State, North Carolina, developed its own devices for applying a load to these weigher's.

(2) Nine of the jurisdictions reported that the police used them for checking overloads on highways, one State reported that they were used at an airport, and they were not used at all in three jurisdictions.

(3) Out of ten jurisdictions where they are used, the weights and measures official was responsible for their being properly checked, in eight instances.

From our own experiences and from a study of the data collected, it is my opinion that the methods might be listed in the following order of preference. This does not include the method which was devised by one State department, because while this is undoubtedly quite an accurate method, it is not widely used. Anyone interested in this method, can learn about it by writing to Mr. C. D. Bancom, Superintendent of Weights and Measures, 415 Agriculture Building, Raleigh, North Carolina.

(1) 'The method which I consider most accurate is the use of test weights, so designed as to fit properly upon the wheel-load weigher platform. 'This method would also require proper facilities for the handling of test weights. Black and Decker use that method in their calibration and checking.

(2) 'The method suggested on pages 149 and 150 of the National Bureau of Standards Handbook H37, entitled "Testing of Weighing Equipment." 
(3) The use of a screw-type testing machine.

(4) The use of a hydraulic testiug machine.

(5) The use of 50-pound test weights.

Listed above are my five choices of testing methods, listed in the order of the best to the least eflicient. I have chosen this order of preference for the following reasons:

The method best suited for any one jurisdiction will depend upen the requirements and accuracy demanded by the agency using these devices. The use of method No. 1 (above) is beyond reproach. I think we ean all agree that applying a definite, known test-weight load to the wheel platform is the best method.

The second method is highly reliable, provided, of course, that the motortruck scale used is correct, as defined by G-D.2., on page 8 of National Bureau of Standards Handbook H44. 'The pull of gravity of a given load, then, can be read both on the scale and on the wheelload weigher. The variations, on a percentage basis, can then we calculated. When a vehicle-scale testing unit is available for this test, it is not difficult to obtain 10 to 12 readings, including the lightest and heaviest wheel loads which the weigher is expected to handle.

The third method, utilizing a screw-type testing machine, whits not quite as accurate as the second method, will be suitable in cases where large tolerances are allowed by the agency using the weighers; for example, as the Ohio Highway Patrol did prior to 1949 , when it 1,000-pound overload was allowed. The screw-type testing machme can be read to within 10 pounds, and has a 1 percent maintenance tolerance. It has the advantage of providing a test for each weigher. and of providing a check of each of the graduations.

The fourth and fifth methods are undesirable. The use of the hydraulic testing machine is undesirable because such machines usually cannot be read with much accuracy, possibly only to the nearest 50 pounds. 'The fifth method is unreliable because the number of 50-pound test weights that can be stacked upon a platform is so small as to preclude a check of the wheel-load weigher within the range of its use.

For your information, it is my belief that the newer design of wheclload weighers is superior, by far, to the older hydraulic type.

Finally, I should like to thank each of you who so kindly replied to my request for information, and also Mr: E. E. Powell of the Black and Decker Company.

The Secrexary. I should like to ask Mr. R. D. Tate of the Engineering Mechanics Section of the Bureau to speak to you briefly about the testing-machine side of this question. He can speak anthoritatively, because his section deals with those machines all the time.

Mr. Tare. The common working tolerances that are set up for testing machines by such societies as the American Society for 'Testing Materials, and by the Federal Specifications Board, are generally 1 percent. However, in the case of new testing machines of the better qualities as now being sold, manufacturers will guarantee an accuracy of one-half of 1 percent. From that standpoint-that is, accuracy alone-the testing machines should be satisfactory for the calibration of a device having a working tolerance of, say, 3 percent. However, you should consider that the testing machine applies a load in a some- 
what different manner than a dead weight does, and if there is any friction involved, that may enter into the question.

In calibrating a testing machine it is the conmon practice to calibrate to read accmrately for a specinlen-such as a steel specimen-which is being broken. Under these conditions the testing machine is calibrated under a slowly increasing load. The increase may be very, very slow, and we try to manipulate the machine so that at the point of failnre of the specimen the load is actually increasing slowly. With the very best type of testing machines, the friction in the machines is quite low, perhaps in the order of 0.2 or 0.3 percent. On some types of machines that are still in use in this country, the figure may be larger than that, bnt I doubt that it would exceed 1 or $1 \frac{1}{2}$ percent even in the wor'st cases.

The qnestion of whether the wheel-load weigher responds in the same mamner when loaded by a dead weight as when loaded in a rigid system having a high spring constant must be considered; the latter factor may introduce errors greater than those introduced by the basic inaccuracy of the testing machine.

Mr. Kinber (American Trucking Association). I agree that the loadometer does register the weight that is placed npon it. But we lave found that in the case of a vehicle combination having 7 axles and 14 wheels, the sum of the 14 individual wheel weights does not agree with the total weight registered on a platform scale. IVe are being prosecnted on the basis of total weights sometimes arrived at by weighing one wheel at a time by one loadometer. WVe feel that the weighing method is not as accurate as it might be.

Mr. Borle. In Maine we go to the State police scale, which is of 30,000 pounds capacity, and test that scale, assuring ourselves that it is correct. We then place a pair of loadometer's on the scale, balance them ont, and then snccessivly apply the front wheels and the rear wheels of a truck to the loadometers, comparing the readings of the loadometers and of the scale. If the loadometer errors are within the tolerance range, we seal the weighers. That seems to me to be a simple way of testing the weighers, and if that is not correct I shonld like to have Mr. Campbell's comments.

Mr. Caxprest. That is similar to the method ontlined in II37, which I did not describe in detail.

Mr. Poweu (Black \& Decker Manufacturing Co.). In 1926 Mr. Harry Roeser, of the National Burean of Standards, made an extensive study on portable wheel-load weighers, otherwise known by our trade name of "loadometers." A Letter Circnlar was issued by the Bureau, and this carried the recommendation that in using wheel-load weighers they should be used in pairs to weigh one axle of the vehicle at a time. Any Higliway Patrol or other enforcing agency which nses only one loadometer and tries to weigh a vehicle by that method is following an irregnlar procedure which we, as manufacturer's, know is inaccurate.

At the time Mr. Roeser's paper was published, there was no such thing as a truck with a tandem axle, that is, two axles which are spaced 4 or 5 feet apart. When tandem axles were first introduced we made a study to develop the proper method of weighing tandem axle vehicles. We found that there were only two accurate methods of doing this. One method was to nse 4 weighing devices, placing all four of the tandem axles in the same horizontal plane just as they 
are when they are on the highway. 'The second method was to use two loadometers under the wheels of one axle, momiting the wheels of the other axle on what we called "equalizing blocks" or" "dummies." By that method the two axles are brought into the same horizontal plane, but this, of course, is a slow procedure because it requires that one axle be weighed, that the vehicle be backed off, and that the loadometers and the equalizing blocks be then interchanged in order to get the weight of the second axle.

I would repeat that in my opinion any State that is using only one wheel-load weigher to weigh a vehicle with $4,6,8,10$, or 14 wheels is certainly not following the correct procedure and I do not believe that evidence secured in that manner would stand up in court.

Mr. Leithauser. Mr. Powell, would you not say that this all sums up to the fact that the loadometer's themselves are accurate but that the method used by many of the Highway Patrols is inaccurate?

Mr. Powelx. I would not say the majority of the States are using inaccurate methods of weighing. At the present time some States are making an axle-load scale by momnting two loadometer's on concrete piers below the pavement level and comnecting the platforms with steel beams the top surfaces of which are flush with the pavement. This is the most accurate method of using the portables, but they are not portable in the sense that we originally had in mind when we designed them to be moved from one location to another.

When you weigh one axle of a vehicle on a pair of loadometers you are elevating that axle about $33 / 4$ inches above the horizontal, and, depending upon how the truck is loaded, you are giving the truck driver an advantage of about 1 to 2 percent; the indicated weight will be slightly less than if the truck had been weighed in a perfectly horizontal position.

Mr. Leithadser. Mr. Powell, would you consider it accurate weighing if two loadometer's are used but the wheels of the other axles are not run up on blocks to bring all axles on a horizontal plane?

Mr. Poweu. There are only two ways of properly weighing a tandem-axle vehicle. One is to use four of the portable weighing units, and the other is to use two weighing units and two equalizing blocks or dummies.

Mr. M. W. Jensen. Mr. Campbell, what precautions are taken by the State of Ohio to assure the accuracy of the screw-type testing machines?

Mr. Campbell. They are tested by the makers of the machines who use proving rings which in turn are calibrated by the National Bureau of Standards.

Mr. Rogens. I should like to know what one of these testing machines costs.

Mr. TAte. I believe that a good machine, having a range up to $50,000 \mathrm{or}^{\circ} 60,000$ pounds, may be obtained now for about $\$ 7,000$ or $\$ 8.000$.

Mr. Rogers. We have been testing these devices first with as much dead load as we can apply, which is not more than 7,000 pounds. 'Then we follow the other methods which have been described here. The platform scale which we use in checking is what might be called a "master scale." 
Mı. G. E. C.nnexter. In testing wheel-load weighers in Vermont I take them over to the Fairbauks plant, place an I-beam across a pair of weighers, and then apply a 10,000-pound test weight such as the factory nses in sealing out their track scales, and then apply two, or four, or six 1,000-pound weights.

Mr. M. W. Jexsex. I slould like to ask Mr. Powell if he believes that the old hydraulic machines can be maintained within an accuracy of 3 percent.

Mr. Pownac. 'The hydraulic loadometer, which was designed in 1924, and which was discarded by us in 1939, uses a pressure cell and a gage. Our experience is that it is difficult to loold these machines to a 3 -percent tolerance, because of the abuse to which they are frequently subjected in service.

\section{BASIS WEIGHTS FOR PAPER AND TEXTILES-R. S. CLEVELAND, NATIONAL BUREAU OF STANDARDS}

In the trade it is common practice to designate paper and textile prodncts by mits of weight, which are in reality the weights of a given area of paper or fabric or a given length of yarn. 'These designations are often very confusing to the uninitiated not only because the areas or lengths involved are ordinarily not stated but also because different areas may be used for different kinds of paper or fabric and different lengths for different kinds of yarn. 'The following summary gives some of the nore common conventions that are used in the two industries. For fuller or more explicit information reference should be made to some of the sources listed in the Bibliogriphy at the end of this paper.

\section{PAper}

The weight of paper per unit area is expressed as "basis weight" which, for short, is often spoken of simply as "weight" or "substance."

In the United States, the generally accepted standard in industry for the expression of the basis weight of paper is the weight in pounds of a ream of 500 sheets of a specified area or size. 'The Government Printing Office, and the printing industry use 1,000 sheets per ream. For some papers a ream of 480 sheets is occasionally used.

The size or area of the sheet used for basis weight of a particular paper is usually established by that part of the trade concerned witl that type of paper. The Technical Association of the Pulp and Paper Industry ('I'API) has attempted to standardize the area or size of sheet by adopting size $25 \mathrm{in}$. $\times 40 \mathrm{in}$. or $1,000 \mathrm{sq}$. ill. 'This area is also often used for comparing the weight of one paper directly with that of another. Other sizes used in this country, depending on the type of paper are as follows:

\section{Kind of paper}

Size, in.

Writing and printing

$17 \times 22$

Blotting

$19 \times 24$

Cover.

$20 \times 26$

'l'issue (double-crown sime)

$20 \times 30$

Cardboard

$22 \times 28$

Blistol and tag

$2.21 \% 2 \times 281 \%$

News and wrapping

$24 \times 36$

Book

$.5 \times 38$

Paperboards

$1,000 \mathrm{sq} \mathrm{ft}$.

$904381-50-11$ 
In Europe, South America, and occasionally for research work in this country, a basis weight of grams/square meter is used.

To illustrate the use of these terms, a "60 pound" wrapping paper would therefore be a wrapping paper of such weight that 500 sheets, each $24 \mathrm{in} . \times 36 \mathrm{in}$. would weigh 60 pounds within a commercial rolerance of \pm 5 percent. 'This would usually be written as weight $60 \mathrm{lb}(24 \times 36-500)$ but might be written simply as weight $60 \mathrm{lb}$. It is apparent, however, from the above, that although the units of size and ream are frequently omitted, it is desirable to state them in any transaction in which they may not be clearly understood by all coulcerned.

The methods outlined above for expressing the weight of paper are only the more common. There are other less common designations. For example, wallpaper is expressed arbitrarily in ounces. The ounce weight has a peculiar relationship to basis weight on a $24 \times 36,500$ basis whereby four times the given ounce weight, plus 2 , equals the basis weight on a $24 \times 36,500$ basis. Thus a 12 -oz wallpaper corresponds to a $50 \mathrm{lb}$ paper on this basis.

\section{Textiles}

Fabrics.-Like paper, the manner of expressing the weight of fabrics is not well standardized and the method of expression is dictated largely by trade custom in a particular part of the industry. Three methods of expressing the weight per unit area are in use.

(a) Ounces per square yard $\left(o z / y d^{2}\right.$ or $\left.o z / s q y d\right)$.-This unit is most widely used in purchase specifications, testing, and as a means of directly comparing the weights of different fabrics. It is also used in the industry for some fabrics such as tire cord fabrics as the usual means of designating the weight of the fabric.

(b) Ounces per linear yard of a given width.-This unit is most widely used for those fabrics in which the width is fairly well standardized. A 15-ounce serge uniform cloth or men's suiting, for example, usually indicates a fabric in which one linear yard, $56 \mathrm{in}$. wide will weight 15 ounces. This unit is also used for some types of duck, as indicated below.

(c) Yards per pound of a given width.--This unit is used for lighter weight fabrics in which the width is well standardized, such as sheeting, percale, and similar materials which are often described by a designation such as 90 in., " $96 \times 108,1.27$ yd." This indicates a sheeting for which 1.27 linear yards, $90 \mathrm{in}$. wide weighs one pound and that the fabric has 96 warp and 108 filling yarns per inch.

The weight of some ducks are expressed in ounces per linear yard of a given standard width. The standard width differs for different ducks and must be stated or known to lave any definite meaning. Other ducks known as "number" ducks" are expressed by a number rumning from No. $2 / 0$ for the heaviest up to No. 12 for the lightest weight. Except for $2 / 0$ and $1 / 0$, the weight in ounces per yd $22 \mathrm{in}$. wide may be found by subtracting the number from 19 . Some of the more common ducks are as follows: 


Flat duck:
Single filling
Double filling
Enamel
Wagon
Army duck
Shoe duck
Belting duck
Bootleg duck
Numbered duck
No. 2/0
No. 1/0
No. 1.
No. 2
No. 3 up to 12

Nominal weight

6 to $15 \mathrm{oz}$

7 to $15 \mathrm{oz}$

6 to $101 / 2$ oz

8 to $12 \mathrm{oz}$

7 to $15 \mathrm{oz}$

7 to $9 \mathrm{oz}$

$22 \mathrm{oz}$ and up

8 to $11 \mathrm{oz}$

No. $2 / 0$ to No. 12

$20 \mathrm{oz}$

$19 \mathrm{oz}$

$18 \mathrm{oz}$

$17 \mathrm{oz}$

$16 \mathrm{oz}$ down to $7 \mathrm{oz}, \mathrm{by}$

$1 \mathrm{oz}$ steps
Width for weight basis

29 in.

29 in.

38 in.

29 in.

$281 / 2$ in.

37 in.

36 in or 42 in.

$40 \mathrm{in.}$

22 in.

Yarns.-The weight, size count, or number of yarns is expressed as the weight per unit length or the length per unit weight, depending upon the type of yarn. The former is termed the foxed length system and the latter the fixed weight system. On the fixed length system the numerical size designation is larger for larger yarns. On the fixed weight system, the numerical size becomes smaller as the yarn becomes larger.

Fixed length system.-The denier notation is by fal the most common in this country of the fixed length systems. The denier of a yarn is the weight in grams of 9,000 meters. Thus 9,000 meters of a 100 denier nylon yarn would weight 100 grams. This system is used principally for reeled silk, nylon, and other synthetic filamentous yarns.

Another example of the fixed length system is found in jute yarns, which is based on a fixed length of 14,400 yards called a spyndle, and on the pound. For" a "20-1b" jute yarn, 14,400 yards would weight 20 pounds. Also the "Grex" system based on the number of grams per 10,000 meters has been proposed as a universal standard.

Fixed weight system. This is the count or number system. The count of a yarn is the number of unit lengths in 1 pound. The unit of length is called a "hank" and varies in length depending upon the type of yal'n. Thus a yaln count of $80 \mathrm{~s}$ ( or 80 's) indicates that 80 standard hanks will weight 1 pound. The small (s) is used to indicate count. Some of the more common standard hanks for different types of yarns are as follows:

$$
\text { Standard }
$$

Yarn hank, yd

Cotton, merino, spun silk_____._. $\$ 40$

Worsted

Woolen (run)

Woolen (cut)

Asbestos (cut)

Linen, wet spun (lea)

TYPP (thousand yards per pound)

For examples of the use of these terms, a 20 s worsted would have $560 \times 20 \mathrm{yd} / \mathrm{lb}$, a $4 \mathrm{~s}$ (or $4 \mathrm{lum}$ ) woolen would have $1,600 \times 4 \mathrm{yd} / \mathrm{lb}$, and a 20 s cotton would liave $840 \times 20 \mathrm{yd} / \mathrm{lb}$. 
Plied yarns.- The size of plied yarns is usually indicated by a notation such as $60 / 2$ or $60 \mathrm{~s} / 2$ where the 60 indicates the count of the single yarn and the 2 is the number of singles twisted together to form the yar'n. Thus an $8 / 10$ cotton yarn consists of 10 strands of $8 \mathrm{~s}$ yarn twisted together. Also, $20 / 4 / 2$ indicates that four 20 's are twisted together and then two of these 4 ply strands are plied to form a yarn.

For worsted yarns the notation is reversed so that the first example would be written $2 / 60$.

The weight of a plied yarn such as $60 / 2$ cotton would be $60 \times 840 \div 2 \mathrm{yd} / \mathrm{lb}$, neglecting contraction due to twisting.

Ropes and twines.-The weight of rope is usually expressed on the basis of "ft/lb" or "lb/ft." A 1-in. diameter manila rope will weigh about $0.27 \mathrm{lb} / \mathrm{ft}$, or have $3.7 \mathrm{ft} / \mathrm{lb}$. The weight of many small twines is expressed as "yd/lb" and medium or larger twines as "ft/lb."

Sash cord.-The weight of this product is represented by a size number which is the number of 32 nd in. in the diameter. Certain other twines also have number designations but these are not associated with diameter and are arbitrary designations.

\section{Standard Atmospheric Conpitions}

Inasmuch as both paper and textiles are hygroscopic materials, their weight is dependent upon the amount of moistnre they absorb from the surrounding atmosphere. Both industries have, therefore, established standard conditions under which tests of weight and other properties should be made. These are

Textiles $6.5 \pm 2 \%$ R. H. and $70^{\circ} \pm 2^{\circ} \mathrm{F}$

Paper $50 \pm 2 \%$ R. H. and $731^{\circ} \pm 2^{\circ} \mathrm{F}$

Materials should be conditioned to moistnre equilibrium with these atmospheres before weighing.

\section{REFERENCES}

This list of references is not intended to be complete, but only sufficient to cite a uthoritative background for the information given above. I'aler :

The Dictionary of Paper. American Iaper and Pulp Association, New York, N. Y.

Basis Weisht of Paper and Paperboard. TAPPI Standard T410 m-45. TAPPI, 120 liast 42d St., New York, N. Y.

Federal Specification UU-P-:31b, Paper, General Specifications and Methods Textiles : of 'Testing. Superintendent of Documents, Washington 25. D. C. 25 cents.

ASTM Standirds on Textiles. American Society for Testing Materials, 1916 Race St., I'hiladelphia, I'a.

Handbook of Industrial Fabries. Wellington Sears Co., 65 Worth St., New York, N. Y.

Knitting Mill Manual. Textile World, 10th Ave. \& 36 th St., New York, N. Y.

American Wool Handbook. American Wool Handbook Co., 303 Fifth Are., New York, N. Y.

Rayon and Staple Fiber Handbook. Rayon Handbook Co., 303-305 Fifth Ave., New York, N. Y.

The American Cotton Handlook. Textile Book Publishers, Inc., New York 16. N. Y.

The Textile liecorder Tearbook. Harlequin I'ress Co., Ltd., Old Colony House, Ianchester 2, England.

Staple Cotton Fabries. John Hoye. McGraw-Hill Book Co., Inc, New York, N. Y. 
Atmospheric Conditions:

Standard for Laboratory Atmospheric Conditions for Testins. Federal standard No. 1, December 15, 1948. Sulerintendent of Documents. Washington 25. D. C. 5 cents.

CHARGES FOR RUG CLEANING-G. H. LEITHAUSER, BALTIMORE, MD.

I have been informed that vears ago when carpet making was in its infancy, carpet was made on what was then known as a Jacquard loom and could not be made any wider than 27 inches, or what was commonly called "three-fourths width," "one-fourth" being equal to ? inches. In those days carpet cleaning was charged for according to the length in yards of the carpet to be cleaned. As 27 inches was the standard width for carpet, the pricing method adopted by the various cleaners in those days seems to me to ha re been all right.

As time went on, the broadloom came into being, and this loom, I am told, was capable of making carpets in wilths up to four feet six inches. As carpet was now being sold in widths greater than 27 inches, the carpet cleaners no longer charged for their service by the loom yard, but based their charges on the so-called "carpet yard," measuring 27 inches by 36 inches, although leaving their customers under the impression that they were paying for this cleaning service on the basis of a 36 inch by 36 inch square yard. To my mind. this basis of pricing was not proper and definitely resulted in giring the ''ustomer short measure in the service which the cleaners were rendering, because there is no such unit of measurement in any of our Anerican tables of weights and measures as a 27 inch by 36 inch carpet rard. This unit of measure shonld never have been adopted by the National Institute of Rug Cleaners as a basis for rug-cleaning charges. This pricing method is not only misleading to the public but is detrimental to customer good will.

In Norember 1947, I wrote to Ralph Smith of the National Burean of Standards asking for a copy of the Standard Weights and Measures of the United States and I received the following reply:

This is in reply to sonr request of November 4 for a cops of the "Standarls of Weights and Measures of the United States."

As sou are nndoubtedly aware, the Congress of the United States has enacter very little legislation with resject to standards of weights and measures. 'The general situation is ontlined to some extent in onr Lettel Cilcula LC6s1, a cops of which is enclosed.

Specifically, the establishment of our standiuds in this country rests largely upon the so-called "Mendenhall Order"' of 1893. A cops of Appendix No. 6 of the report of the 'Treasury Department, containing this older", is likewise enchosed. The circumstances leading up to this ordel are set forth in the early part of the enclosure. It is probable that this docment, and particularly the secomd of the conversion tables appearing on page 169 thereof, will serve sour present purpose.

It seems clear that there is no legal justification for representation that in connection with rug cleaning a nuit of 27 inches by 36 inches constitutes a "square rard" in this country.

Very truly gours,

R. WV. SмITH, Chict,

Office of Weights and Measures.

After reviewing the documents mentioned in Mr. Smith's letter I agreed with him when he said that it seems clear that there is no legal justification for representation that in connection with rug cleaning a unit of 27 inches by 36 inches constitutes a "square rard" in this country. 
In my jurisdiction I have been handicapped in having rug cleaners in Baltimore charged with giving short measure on rug-cleaning jobs. In November 1947, I asked the City Solicitor's Office as to my authority to prosecute under Article 97, Section 30, Annotated Code of Maryland, Flack, 1939 edition, which says:

Any person, firm, or corporation who shall knowingly and willfully give short weight or short measure to anyone purchasing any article or commodity shall be guilty of a misdemeanor and shall on conviction be fined not less than twentyfive dollars or more than five hundred dollars.

\section{I received the following reply:}

It is felt that the above Section is not applicable to your situation in that its language refers specifically to the giving of short weight or measure "to anyone purchasing any article or commodity." Inasmuch as the cleaning and dyeing business consists of the sale and purchase of services rather than of an article or commodity, the provisions of Section 3 cannot be applied thereto. You are therefore advised that it is my opinion that Article 97 of the Annotated Code of Maryland, Flack's 1939 edition, provides no legal basis for the prosecuting of cleaners and dyers charged on the basis of the English yard.

I could possibly prosecute under the statutes against obtaining money under false pretenses or by fraud, but as these statutes are not intended for weights and measures enforcement, I hesitate to do so. I believe that weights and measures officials should adhere to their own statutes and leave the enforcement of other statutes to the proper officials. However, I am preparing to present to the City Council shortly an ordinance covering the giving of short weight or short measure to any person, firm, or corporation on services rendered.

When I received this program assignment $I$ wrote to all of the rug cleaners in the City of Baltimore as follows:

At the 35th National Conference on Weights and Measures, which will be held at the Wardman Park Hotel in Washington, D. C., on May 23, 24, 25, and 26, one of the subjects for discussion by weights and measures officials will be charges for rug cleaning. If you would be interested in this subject, please have a representative at this Conference to explain your position regarding the above matter. If there are any out-of-town officials that would be interested in this subject, advise the writer, so that he may contact them regarding same.

On March 6, 1950, a representative of one of the rug-cleaning companies wrote me as follows:

We are very much interested in "charges for rug cleaning" to be discussed at your 35th National Conference. Since the dates of this Conference occur at the height of our season, we would appreciate knowing on which day this discussion will be held. We thank you for your cooperation in this matter and will try to be present.

Later I communicated with the writer of this letter, and was told that they would probably have at the Conference a representative of the National Institute of Rug Cleaners to present their side of the story. If there is anyone present this morning representing the National Institute of Rug Cleaner's, I think we should hear from him at this time.

Mr. Berg (National Institute of Rug Cleaners). I am from the National Institute of Cleaning and Dyeing, but I represent the National Institute of Rug Cleaners. The facts given to you by Mr. Leithauser regarding the charging for rug cleaning on the basis of a 27 inch by 36 inch yard are substantially true. As far as I am concerned, and as far as the National Institute of Rug Cleaning is concerned, we are certainly in agreement with the proposal that this prac- 
tice be abandoned. In fact, nation-wide, I understand that it is not too prevalent, but there are certainly some places in which they are charging on that basis. If it is appropriate, I should like to recommend at this time, in the name of the National Institute of Rug Cleaners, that the square foot be used as a basis for charging for rug cleaning.

Mr. Leitirauser. You mean a square foot of 12 inches by 12 inches?

Mr. Berg. That is correct. I think I should say that the insinuation is not quite as bad as it would seem. I believe that rug cleaners are ethical, and that the evolution of pricing on the basis of a 27 inch by 36 inch yard is understandable. But since there is another basis, and since they have gone to the wider broadlooms, I would say that the practice is antiquated. However, I would not want anybody to think that we are chiselers and trying to cheat the public. It was a natural evolution, please believe me.

Mr. Baucon. I move that the suggestion of Mr. Berg be referred to the Conference Committee on Methods of Sale of Commodities for consideration and report next year.

(The motion was seconded, the question was taken, and the motion was agreed to.)

CALIBRATION OF TANK CARS-H. H. RUSSELL, NATIONAL BUREAU OF STANDARDS

The calibration of tank cars seems to have been a little-discussed subject. I had always assumed that the handling of petroleum and other liquids in bulk quantities was something that was being effected in a manner that was satisfactory to all concerned, but without any great attempt at precision. As I have recently looked into the subject I have been surprised. I learned that procedures are well standardized, and that the calibrating and gaging methods now in practice result in highly accurate calibration. As an example, I wish to read to you a statement that was enclosed in a letter from Mr. R. M. Smith, Vice President of the Union Tank Car Corporation.

Over 40 years ago the Union Tank Car Company realized the necessity for the accurate determination of the capacity of tank cars. After a thorough investigation by the officers of the company, it was decided to construct a specially designed water gage plant consisting of a series of tanks to lold and discharge a known quantity of water within very close limits. These tanks were very accurately calibrated, using as a basis a measure the capacity of which was certified by the National Burean of Standards.

The volumetric capacity of each tank car was determined by water gaging. This method of calibration has been in use by us continuously for over 40 years with only minor refinements. The API Code for determining the volumetric capacity of tank cars by the water gage plant method is based upon and is essentially the same as the method in use by the Union Tank Car Company.

Actual tests of the capacity of tank cars detelmined by the water gage plant method at different plants of the Union Tank Car Company proved conclusively that this method is extremely accurate, there being less than 0.02 -percent difference between the high and the low.

When I wrote to the Union Tank Car Company, the American Car and Foundry Company, and the General American Transportation Company, I asked several specific questions for my own information. I am going to read those questions and the answers at this time.

There are two principal methods used for the calibration of tank cars. One is the water-gaging method, and the other is the so-called "strapping" method under which the capacity of a tank car is deter- 
mined from measmrements of the exterior dimensions, due allowance being made for the shell thickness. My first question was, "Which method is being employed by your organization and under what circumstances is the alternative method nsed, if ever?" When I said "alternative method" I was referring to the strapping method. All three companies replied to the effect that they used the water-gaging method exclusively.

The second question was, "What would be the customary procedure in the case of a tank car which had been obviously damaged or otherwise altered in a manner that would impair the original calibration?" The answer to that question as supplied by the Union Tank Car Company was, "It has been the practice of the Union 'Tank Car. Company for many year's to regage any tank car damaged in any manner which would affect its capacity."

My next question was to determine whether or not each tank car is separately calibrated, or whether a representative sample of a type is calibrated and all other cars of that type are marked in accordance with the results obtained on the sample. The answer which I received from all of the companies was to the effect that each tank car is separately water-gaged.

We are very fortunate this morning in having present a gentleman who is an engineer with the Union Tank Car Company, who has been personally in charge of the calibration and gaging of tank cars for his corporation. I am going to ask this gentleman to come to the platform, and I would like to have you direct your questions to $\mathrm{Mr}$. Hiatt, of the Union Tank Car Company, and I would ask that you keep your questions close to the subject of the calibration of tank cars.

Mr. Hrater (Union Tank Car Company). I may say that Mr. R. M. Smith, Vice President of our Company, is the Chairman of the API subcommittee on calibration which prepared API Code No. 1201, July 1948, "Code for" 'Tank Car Quantities or Code for Calibrating 'Tank Car' Tanks and for Measuring, Sampling, and Calculating Tank Car Quantities (Non-Pressure Type)." The calibration by the watergage plant method appearing in that code is essentially the same as was developed and used by the Union 'Tank Car Company for the past forty year's.

If you have questions I should be glad to try to answer them.

Mr. Folmspes (American Car and Foundry Company). The socalled strapping method was in use for a considerable length of time, but is not too accurate because it is dependent upon outside measurements and calculations of the volumetric capacity. At the present time I do not believe there is anyone in the comntry using that method. In the new code being prepared at the present time to cover pressuretype tank cars, which handle compressed gases and LPG, the watergage plant method is being used as the most accurate method for calibrating tanks. But I believe that an alternative method of water weighing should be mentioned. Is that correct?

Mr. HritT. That is correct. In that new code the strapping method as an alternative method has been superseded by the water-weighing or gravimetric method of calibration. The water-gage plant method is still the recommended method, and is the more accurate.

Mr. 1. T. Smrrн. Bjerregard's tables of corrections give identical outage and inage for any particular class of tank cars, and for every 
dome of a given diameter the inage figure is identical for every car. Ilso, the outage on the 10,000-gallon tank car's is identical for every lank car of the so-called 10,000-gallon class. Actually, they run up as high as 10,200 gallons.

'There are many of these cars, 20 to 30 years old, made by manufacturers who do not or did not use at that time either the waterweight or water-gage methods of calibration. The tanks had been strapped. I believe that either the owner or manufacturer of a tank car has the privilege of turning in rated capacities to the Kipp's Tariff $300 \mathrm{E}$ which lists every tank car in the United States, and such orner or manufacturer is responsible for any error. It may be possible, but is it probable that every dome of a given diameter on a 10,000-gallon rank car will take the same inage, and that every tank car of the 10,000 gallon class will have the same outage?

Mr. Hiats. I have in my hand a book of outage tables that the Union Tank Car Company has on its pressure tank cars, of which we own approximately 3,500. This book contains outage tables. Picking a page at randon, here is one page set $n$ p at 10,027 gallons. Here is another at 10,042 gallons. In other words, we do not have a standard gage table that covers every 10,000-gallon tank car. We have them covered, not in individual capacities, but within a certain range.

Mr. A. T. Sirtm. When I said every tank car I was referring to Bjerregaard's tables that are apparently used by many receivers for the determination of quantities received. I understand that the Union 'Tank Car Company is one of the manufacturer's which does nse the water-weight method and tries to do things correctly. However, there are many other's. 'There are apparently thousands of cars in service that have been calibrated incorrectly and which are in daily use in the transportation of oils, gasolines, and other liquids. I think that every tank car that is coming ont of the shops as of now should be water-gaged so that it may be accurate just as in the case of other devices that are used for measuring processes. After all, a tank car is a measure.

Mr. Hiatr. The petroleum industry has recognized that need, and here is the result. We have API Code No. 1201, on tank-car quantities. Not only does it cover calibration methods, but it also covers methods of measuring, sampling, and calculating tank-car quantities. It is an industry code covering those subjects in detail and very well. So the very thing you are asking for has already been done by the oil industry.

I should like to read an excerpt from an article on "Program for Loss Control in Manufacturing and Handling Operations," by Mr. J. H. McClintock of Esso Standard:

In 1941, eren before the United States entered the war, Jersey [that is the Standard Oil of New Jersey] initiated large volume movements of crude petroleum on the Atlantic Seaboard by tank car, so that losses occurring in tank-car operations, loading, in transit, and unloading, were considered as anong the first in the study of tramsportation losses. Flom tests conducted on tank cars handling crude and nonvolatile products it was determined that the physical losses in tank-car operations were negligible.

Mr. Folnsbee. I should like to comment on differences in capacity. 'There are errors when the strapping nuethod is used. We have recently gone to the water-gage plant method of measuring. Out of an order of 100 cars, built, let ns say, to 10,000-gallon capacity, there will be 
variations between the capacities of each one of these cars even by the most accurate measurements. It is our practice to furnish outage tables to the customel, and those outage tables will vary within a close range for a group of cars. So accurate measurement can be obtained if those tables are used. One fixed table on the basis of a 10,000-gallon tank car will not give that accuracy.

Mr. Hratr. The Union Tank Car Company also owns cars which were not water-gaged, cars purchased from outside companies. We have a program under which these cars are run through the watergage plant as fast as we get them in, so that we will have accurate calibration on all of our cars. All of our new cars are water-gaged.

Mr. A. 'T. Suritr. 'That is an admirable program, and it is very gratifying that steps have been taken to correct this situation.

WHOLESALE LABELING OF MEAT PRODUCTS-DR. J. R. SCOTT, BUREAU OF ANIMAL INDUSTRY, U. S. DEPARTMENT OF AGRICULTURE

I am indeed happy to have this opportunity of meeting with your Conference and sharing in the discussions of the problems incident to the labeling of meat products.

Since this group is primarily interested in the net-weight markings, I will limit my' remarks to that phase of labeling. I assume that most of you are familiar with the part that the Federal Meat Inspection Service plays in the labeling of meat and meat food products, but in order that there be no misunderstanding concerning our responsibilities in the matter, I think it would be well to briefly review the background of our service.

Federal meat inspection dates back to 1890 when the first meat inspection law was enacted. This law was designed to facilitate the exportation of meat to foreign countries and did not afford much protection to the citizens of the United States. As a result of the great clamor for an improved system of meat inspection, in order to correct some of the appalling conditions which existed in the meat industry, Congress passed the Meat Inspection Act which became effective July 1, 1906. Our present meat inspection regulations were issued under the authority of this act and succeeding acts and apply to all slaughtering and meat processing establishments that prepare meat and meat food products for interstate and foreign commerce. The principal purpose, as stated in the Meat Inspection Act, is to prevent the use in interstate or foreign commerce of meat and meat food products which are unsound, unhealthful, unwholesome, or otherwise unfit for human food.

In carrying out the provisions of the Meat Inspection Act and Regulations promulgated thereunder, our present system of Federal meat inspection includes the following responsibilities:

1. To examine food animals including cattle, calres, sheep, swine, goats, and horses prior to slaughter to eliminate diseased animals.

2. To conduct a thorough postmortem examination of each animal at the time of slaughter "to search out and eliminate diseased and otherwise unfit meat.

3. To destroy for food purposes diseased meat and otherwise unfit meat and meat food products.

4. To see that the sanitary condition of the plant and equipment is such that food products may be kept clean and wholesome during the stages of preparation into articles of food. 
5. To guard against the use of harmful preservatives and other deleterious ingredients.

6. To cause sound and wholesome meat and meat food products to be marked as having been inspected and passed.

7. To require informative labeling and to prevent the use of false and deceptive labeling on meat and meat food products.

8. To certify meat and meat food products for export.

9 . To inspect meat and meat food products offered for importation into this country.

10. To examine meat and meat food products for compliance with specification requirements of governmental purchasing agencies.

11. And to assure proper post mortem diagnosis and disposition of carcasses and parts.

With this introduction, I believe we are ready to consider the specific subject "Wholesale Labeling of Meat Products". My remarks will, of coul'se, be confined to the labeling requirements of the Federal meat inspection service. Our primary interest is the same as yours-that is, that the product be truthfully labeled and that the label contain no misleading statements.

Our regulations state that,

When any inspected and passed product is placed in a container or covering constituting an immediate or true container, such covering or container shall carry a label showing:

The true name of the product.

The word "ingredients" followed by a list of ingredients arranged in the order of their predominance.

The name and place of business of the manufacturer or person for whom the product is prepared.

An accurate statement of quantity of contents.

And an inspection legend with the idlentifying establishment number.

Such labels may only be used under the supervision of a Meat Inspection Division employee after the label has been approved by the Trade Label Section of the Meat Inspection Division.

Our regulations are quite brief as to statements of content. They are standard regulations which appea in the Food and Drug Regulations, but I might read a part of the regulations:

'The statement of quantity shall represent in terms of avoirdupois weight or liquid measure the quantity of product in the package (exclusive of materials packed with it) except as provided for in subparagraph 17.7. When no general consumcr usage to the contrary exists, the statement shall be in terms of liquid measure if the product is liquid, or in terms of wcight if the product is solid, semisolid, viscous, or a mixture of solid and liquid. Unless the statement is so qualified as to show that it expresses the minimum quantity, it shall be taken to express the actual quantity. When the statement expresses the minimum quantity, no variation below the stated minimum shall be permitted, and variations above the stated minimum shall be no greater than consistent with filling the container to the stated minimum in accordance with good commercial practice. When the statement expresses actual quantity, variations incident to packing in accordance with good commercial practice shall be allowed but the average shall not be less than the quantity stated: Provided, That packages of product haring a capacity of less than one-half ounce avoirdupois or less than one-half fluid ounce shall not be required to be labeled with the statement of the quantity of contents.

When any product is enclosed in a container along with a packing substance such as brine, vinegar, or agar jelly, a declaration of the packing substance shall be printed prominently on the label in connection with the name of product, as, for example, "frankfurts packed in brine," "lamb tongue packed in vinegar," or "beef tongue packed in agar jelly," as the case may be. The statement of the quantity of contents shall represent the weight of the drained product when 
removed from the container to the exclusion of the packing substance. The packing substance shall not be used in such a manner as will result in the container being so filled as to be misleading.

'These regulations all sound very simple. However, we do encounter a few headaches. For the most part meat is packed and labeled on the day that it leaves the establishment. In this class of product we liave no problem. Nor do we have a problem in connection with the product in hermetically sealed cans. Where we get into a problem is where the meat is packaged and for some reason it is not removed from the establishment on that day but is put back in storage on the premises. Meat in certain types of containers is known to shrink, depending on various conditions, time in storage, the type of refrigeration, and it is necessary to make a very close check on the product when it is removed from storage and is offered for transportation from the plant.

Our inspectors check the weighing of the prodnct when it is packed and they again check the net weight of representative samples at the time of shipment from the official establishment.

I want to emphasize the point that it is the responsibility of our inspectors to assure themselves that the product bears an accurate statement of quantity of contents at the time the product leaves the oflicial establishment, but unfortmately their responsibility, as stated in the Meat Inspection Act, does not extend beyond the limits of the official establishment.

In closing, I would like to extend an invitation to all of you to call on our inspector's in charge of your various jurisdictions for the purpose of discussing any mutual problems you may have on the labeling and the net-weight marking of meat food products. We have inspection in some 1,000 establishments. They are located in approximately 350 cities. These cities are located in practically every State in the Union. If you do not know our representative in your particular State or city, we will be happy to furnish you upon request with a directory which furnishes the names and the addresses of our representatives in the field.

Mr. WiтT. Most packers of meat, whether they ship interstate or intrastate, include on their invoices the statement. "No allowance in any case is made for natural shrinkage." I have in mind a wholesaler of meats in Milwankee who buys pork loins which are shipped to him from Chicago; the natural shrinkage is always 4 to 5 percent. He also buys the same type of pork loins from Iowa, and the shrinkage on these is consistently 1 to 2 percent. Does the Bureau of Animal Industry have any regulations regarding shrinkage?

Dr. Scotr. No. I believe you have posed two questions. The first involves the variation in the amount of shrinkage. As I have already pointed out, there are various factors which influence the loss in weight. In the case of the shipment that lost 1 to 2 percent, it is quite probable that the factors included a higher humidity and perhaps a shorter time between the weighing and receipt of the shipment by the wholesaler.

The other question you raise deals with the statement that appears on the invoice. TVe have no jurisdiction over statements made on invoices. Our responsibility is to see to it that the meat is accurately market at the time of shipment.

Mr. Wiтt. Do you consider a shrinkage on pork loins of 4 or 5 percent to be normal and all right? 
Dr. Scorr. I do not think it is all right. I certainly think that there should probably be an adjustment in price. I certainly would not want to biny a box of pork loins and take a 4 percent loss.

Mr. WiтT. Wonld your agent in Milwankee assist us in getting such an adjustment?

Dr. Scotr. I do not believe that we can do so. I do not think our jurisdiction would extend that far.

Mr. WrTT. But you do not think that a consistent shortage of 4 or a percent results for normal shrinkage?

Dr. ScoTr. I do not know just what we can pin down as "normal shrinkage." In the plant itself we have products that are stored in a particular room with a particular type of refrigeration, which come out with a very, very low shrinkage--even with no shrinkage at all, or so little that it is not necessary to change the marking at the time of shipment. A similar product, packed in a refrigeration space that has the same physical conditions as the room previously mentioned, may come ont with a loss of 2 or 3 percent; in all such cases we require that the product be reweighed and remarked at the time it leaves the establishment.

I do not know how we can arrive at what a normal shrinkage should be. As factor's involved, there are the type of wrapper used, the type of refrigeration, the time elapsing between packing and marketing of the product, and the time required for the product to reach the retail level.

Mr. Ricinard (Packer's and Stockyards Division, U. S. Department of Agriculture). The Division I represent comes into this picture only when there is evidence of a violation of a trade practice, a perpetration of fraud, a deceptive or discriminatory practice, and so forth. If there is evidence of deliberate, intentional, incorrect weighing or marking of weight, we can proceed under the provisions of the Packers and Stockyards Act, which empowers us to prosecute the packer.

I think it shonld be said to the credit of the great majority of meat packers, that an extremely small number of instances of incorrect weighing or marking of neat come to our attention. An occasional small slaughterhouse operator or local packer may engage in such practices, but even there the cases are relatively few: in such of these instances as we have had to act mpon, the faulty conditions have been immediately corrected.

Mr. Rogirs. I shonld like to ask Dr. Scott about meat products which are processed or packed in these heary casings which give all the appearance of a container. I believe that some jurisclictions allow these to go unmarked. Are we to understand that the Federal Government does the same and does not require a net-weight marking on this type of package?

Dr. ScoTr. That is correct. Many years ago an administrative ruling was made in onr Bureatu, under which meat products in casings were excluded from the provision for net-weight marking; that has been extended to include artificial casings. I should emphasize, howerer, that compliance with our requirements does not relieve the processor from complying with any State reqnirements which may be in effect. 
Mr. Rogers. If such products are to be exempt from the net-weight marking requirements, I feel that they should carry a definite and clear statement to the effect that the product is to be weighed at the time of sale. Products packed in these artificial casings look different from products packed in animal casings; they look as if they were put in a bag, even though the product may be prepared and processed in that bag.

Mr. Badcon. Dr. Scott, if the packing elements you refer to are edible, may the weight be included in the net-weight declaration?

Dr. Sсотт. Yes, if it is edible and if it has food value. For example, in the case of canned hams, varying amounts of free juices result from processing the ham in the can. These juices may represent as much as 15 to 20 percent of the weight of the contents of the can. They are included in the net-weight statement because they are an edible product. But our regulations exempt such substances as water, brine, vinegar, agar, and agar jelly.

Mr. Bavconr. Would the percentage of the packing element be shown in the declaration of the net weight?

Dr. ScotT. No. It would be shown in the ingredient declaration, or it may be taken care of in the name of the product. For example, if we have frankfurter's packaged in brine, the name of that commodity is "Frankfurters packed in brine"; if the statement of content reads "Net weight, 12 ounces," that means there are 12 ounces of frankfurters after the brine has been drained a way.

$M_{R}$. BAdcom. But suppose the packing element is edible. What I am trying to get at is the percentages of the edible ingredients; for example, in the case of the canned ham, the percentage of ham and the percentage of juices.

Dr. Scotr. There again the name of the product describes the finished article. In your example it would be "Ham with natural juices." There would be no practical way of showing the percentages because the amount of natural juices varies in the same pack, depending on the kind of ham and the type of musculature; even when subjected to the same processing-temperatures and time-the juices may vary 6 or 7 percent in the same pack.

Mr. BadCom. Your inspectors Dr. Scott, camnot possibly weigh every package. How do you know how many they do weigh and what methods they use to satisfy themselves that meats are being correctly weighed?

DR. ScotT. We have supervisors who check on the operations of the inspectors. The packers weigh every can or every package. The inspector checks a reasonable number, and he makes a second check at the time the product reaches the loading dock for shipment. Packages are selected at r'andom and these are weighed. If the samples weighed are found to be inaccurately marked, additional samples are taken and weighed. If these, likewise, are found to be inaccurately marked, the inspector throws the whole shipment back to the processing department for reweighing and remarking.

Mr. BAvconr. What about carcasses, halves and quarters that are simply shipped in sacks or cheesecloth.

Dr. Scotr. If the quarter- or half-carcass is not in package form, we do not require a statement of weight. If the weight is shown, as it usually is, we observe enough of them and have enough of them 
weighed to make certain that the average is correct. It would be impossible for our inspectors to weigh each carcass. But if a goodly number of samples are found to be accurate, it is self-evident that all are accurate.

Mr. J. T. KenNedy. Getting back to packaged products, you stated, Dr. Scott, that they are weighed at the time they are wrapped and that they are rechecked at the time of shipment. Do you allow any shrinkage tolerances between those two points?

Dr. Scotr. You will understand, of course, that there is a commercial tolerance in weighing and packing. We do not permit a tolerance. The average weight at the time of shipment must be correct.

Mr. J. T. Kennedy. Do your inspectors ever find an overage when checking the weights of hams?

Dr. Scotт. Occasionally, yes.

Mr. J. T. Kennedy. 'That must certainly be a rare occurrence. Every ham that we receive in the District of Columbia is short weight when received. We know definitely that there is shrinkage in a period of 12 or 24 hours. I feel sure that hams checked at the time of wrapping and then checked at the time of shipping would show a shrinkage.

Dr. Scotr. Wrapped hams are usually wrapped and shipped on the same day by train or truck. In most of the packing plants it is not the normal way of doing business to wrap hams and then store them in the plant for even 24 or 48 hours.

Mr. Baker. Dr. Scott, your Bureau approves labels; does it not?

Dr. ScotT. That is correct.

Mr. Baxer. You have stated that a label must carry an accurate declaration of net weight. We have found meat products which were labeled as so many pounds and ounces "when packed." Is it the general practice of your Bureau to approve labels which carry qualifying phrases? Many States do not permit that; we do not.

Dr. Scotт. The qualifying statement, "when packed," means nothing as far as the Bureau of Animal Industry is concerned.

Mr. BAKER. It does mean something to the State of New York and to other States. It meant a great deal to the packer in the particular case I have in mind, because he had ordered a large supply of labels in good faith, believing that they would be acceptable in all State jurisdictions. In this instance, the packer had to discard the faulty labels. When your Division approves a label, it would seem advisable that you let the packer know that he should also obtain the approval of the States where the labeled product is going to be sold.

Dr. ScotT. When labels for meat and meat-food products are submitted to us and the label carries a qualifying statement, we always warn the person submitting the label that the qualifying statement has no meaning and that the stated weight must be an accurate weight as of the time the product leaves the plant. Our Division has no responsibility over poultry.

Mr. Stariws. Dr. Scott, what shrinkage loss would you say there should be on the average weight of packages traveling a distance of 28 miles in one hour in refrigerated trucks?

Dr. Scotr. It shouldn't be to much if conditions are favorable, but I am not qualified to give you a figure. 
Mr. Searies. Would you say it should run as high as 3 or 4 percent?

Dr. SCor'T. I would not say so.

Mr. J. T. Kennedy. Dr. Scott, I have here an example of a qualifying statement, printed in type so small that I can't read it. Will you look at it?

Dr. Scotr. This is an invoice, and as I have already said we have no jurisdiction over the invoicing of the products. Our responsibility is simply that the product must bear an accurate statement of contents at the time of shipment.

IMPROVING THE SERVICE OF THE NBS OFFICE OF WEIGHTS AND MEASURES TO OFFICIALS AND MANUFACTURERS-W. S. BUSSEY, NATIONAL BUREAU OF STANDARDS

The primary objective of the Office of Weights and Measmres is to promote greater service and protection to the citizens of the Nation, through cooperation, coordination, and efficiency on the part of State and local weights and measures enforcement officers. The Office of Weights and Measures was established as a separate Division of the National Bureau of Standards in October 1947. Since that time it has been possible for the Division to carry on a more active program of cooperation and assistance to weights and measures officials and representatives of industry than had been practicable theretofore.

The principal features of our program are sponsoring the National Conference on Weights and Measures, making personal visits to State and local weights and measures offices, assisting various jurisdictions in the preparation of laws, ordinances. and regulations, preparing helpful publications on weights and measures subjects, and attending State and regional weights and measures conferences.

We have endeavored to encourage State and local weights and measures officials to attend and participate in the National Conference on Weights and Measures. We have attempted to interest all States and the principal local jurisdictions in the short course on the calibration of standards which was conducted by the Burean; 16 officials have taken advantage of that course, and we were disappointed that more have not responded to our invitation. In our personal visits to officials, we have tried to be helpful toward improving administrative conditions by discussing existing problems and suggesting solutions. We have encouraged officials to obtain more nearly adequate equipment, and have assisted officials in some instances by presenting this idea to their superiors.

These personal visits have given us the opportunity of becoming better acquainted with weights and measures enforcement officers. They have enabled us to make close, firsthand studies of existing problems, to examine testing equipment, and to discuss methods of enforcement and testing procedures. In general, we have been enabled to learn a great deal abont weights and measures administration in the United States. Such information should place us in a better position than before to be helpful, because we have the opportunity of passing on the good ideas picked up in one jurisdiction to officials in other jurisdictions who are confronted with like problems.

We have assisted several States and cities in the preparation of laws and ordinances which have been enacted, and we are still working 
along these lines with several other jurisdictions. TVe have encouraged all jurisdictions to adopt nnifor'm specifications, tolerances, and regulations based upon the National Conference recommendations. Through our attendance at State and regional conferences we have tried to make constructive contributions and encourage more efficient weights and measures administration. Mr. Smith is well along in the preparation of the manuscript for the new handbook on the testing of measuring devices, which will be a companion handbook to $\mathrm{H} 36$ and should be a useful addition to the Bureau's series of handbooks.

That is a summary of what OTVM has been doing. It is our desire to render the utmost service to weights and measures officials and others with the facilities placed at our disposal. 'The purpose of this discussion is to give you the opportunity to express your thoughts concerning the program of the Office of Weights and Measures. Do you think the present program is wortle while! Do you think that the personal visits to State and local offices should be continued? Do you think that the practice of attending and participating in the various State and regional conferences is desirable? IThat additional services can we render? How can we improve upon the services that we have already been attempting to render? Specifically. what can we do for you?

The Office of Weights and Measures exists for the purpose of serving the veights and measures administrative officials of this Nation and all others who are interested in weights and measures problems. Our service is strictly cooperative and advisory. We can only serve you if it is your desire that we do so and if you request that service. WVe want your slogestions as to how we can best selve.

Mr. R. D. Thumpon. Mr. Bussey, your progran has restainly been lielpful to all of the States that liave availed themselves of your services. To what extent ale the States and localities availing themselves of those services?

Mr. Bussey. I have no figures on the number of States which have requested services of various kinds. These have been numerous, but there are many local and State jurisdictions which have not called upon us for assistante. We get frequent request from some jurisdictions, and there are others from whom we hear rarely, if at all.

Mr. R. D. Thommson. I shomld like to make the point that the Oflice of IVeights and Measures is covering the entire United States and has an over-all picture of what is going on, and that it is decidedly to onl advantage to avail onselves of all of the help which we cail get from the Bureau.

Mr. J. 'T. Kennemy. MIr. Bussey, you say that you do receive certain requests for assistance from varions agencies. Is it the policy of yom Division to send copies of this correspondence to other agencies who might be confronted with the same problem? In other words, are you furthering the work without request?

Mr. Bussm. "The general answer is, "No." Howerer, when some problem comes up that we think is of interest to varions jurisdictions, information on that problem is sometimes furnislred to the Scale Journal and to the associations and State oflices that publish news letters and which have requested that service. An illustration is the Southern Association News Letter. We receive regular requests from

$904381-50-12$ 
the Chairman of the Association Education Committee, Mr. Crawford, for any items of general interest to the weights and measures officials of the States that make up that Association. If these other associations or other publishers of news letter's would like to have that same type of service, we should be glad to give it to them.

Another illustration is in relation to the interpretations of $\mathrm{H} 44$ rerequirements which are made officially by the Committee on Specifications and Tolerances when they are called upon for an official interpretation of a code requirement. Such official interpretations are furnished to the Scale Journal for publication and they can be made available to any of you people who issue news letters, if you so desire.

Mr. J. T. Kennedy. Has the Bureau of Standards given any consideration to bringing back the news letters which they issued back in 1942, 1943, and 1944? Personally, I looked forward to receiving that publication. It was a clearing house through which we could distribute information.

Mr. Busser. No consideration has recently been given to reestablishing that news letter. It seems to me that the field is rather well covered by the news letter's now being published by the various State and regional organizations. I do not know how many officials in other jurisdictions are receiving those news letters, but I know that some of the publishers of those news letters are willing to send them to almost anyone who requests copies.

Mr. Fuller. I have talked about this to many officials, and every one of them regrets that that news letter has been discontinued. I think that could be the one medium for reaching entirely throughout the country and distributing at one time this information that we all should have. I think we should like to see consideration given by the Bureau to re-establishing the news letter.

Mr. Boyle. I wish to state that in my opinion the visits by a representative of the Office of Weights and Measures to the different weights and measures jurisdictions throughout the country should definitely be continued. I also feel that these personal contacts should be supplemented by the news letter; it is of great value to officials to receive information coming from the Bureau of Standards.

Mr. Bussex. We may not be able to meet every request which is made to us, but we can guarantee one thing: We shall do our best to help you at any time that you think we can be of service.

STRAIN-LOAD TESTS AND BUILD-UP TESTS-S. H. CHRISTIE, JR., NEW JERSEY

The weights and measures officials as a group have always been confronted with the problem of adequate tests of commercial devices used in the weighing or measuring of the various commodities passing from the producer or dealer to the consumer, or those employed in the other several channels of barter and service. The practical applications of the results of the modern sciences have aggravated this condition because modern governmental groups have failed to keep comparative pace with the facilities being provided to industry. This failure has been indicated by not providing the necessary complements of working standards, provers, and equipment, and is due to local economic affairs, indifference to the facts, or not properly recog. 
nizing conditions and needs. These facts also apply to industry except that they cannot claim to be unacquainted with their own needs.

This is very true of the scale end of the situation. Modern weighing machines of the large-capacity or so-called heavy-duty type have capacities and are used to such capacities as were not thought to be practical a few year's ago. These devices are being so used that the economic value of the substances being handled requires a very high degree of accuracy.

Unfortunately these devices are usually installed with very little consideration given to proving them, and as a result are not always favorably located for easy access or are not always provided with suitable means to run a satisfactory test with a complement of working standards to the scale's capacity or the capacities in use. Thus the weights and measures field operator and the scale man find themselves in more or less of a dilemma, one to satisfactorily prove out the device officially, the other to prove out both the device and his work. As a result of these circumstances, both groups are forced to invoke the principles of either the "substitution" or "build-up" method of testing, or the application of strain loading the device in conjunction with the use of the largest practical increment of sealed test weights possible.

The mathematical and engineering definition of the word "substitution" means to "substitute for" or "to replace one thing with another of equal value", and this principle when applied to the testing of scales means that extraneous available materials are substituted for the known test weights during the test and in increments equal in value to the known test weights in use, and, further, the calibration of this extraneous material is made during the test and by the machine undergoing the test.

In a test of this type, the following steps are made: First, the scale is given a sensibility-reciprocal test under no load. Second, the scale is very carefully balanced. The balance condition obtained is one that can readily be duplicated, as in the case of a weighbeam that just fails to strike or bump the top of the trig loop on its first rise after being released from the bottom of the trig loop, or, where an auxiliary device is used, the proper coordination of the indicator and a graduation is made. This balance is obtained by the use of the scale's normal balancing mechanism and this mechanism should not be used again until the test has been fully completed and the full complement of weight involved is removed from the scale and the change in zero balance investigated.

Third, if the complement of known test weights being used is sufficient in capacity, a regular corner or shift test is made, provided, however, the scale's platform facilities will so allow, ending with the test weights in the center position and the results noted. The balance obtained is made in the same manner as the original or zerobalance condition of the device.

Fourth, the test-weight load is very carefully removed and replaced with the available foreign material until the balance condition in the previous step is exactly duplicated. Extreme care must be employed in both the removal of the test weights and the application of the foreign material at all times, in order to avoid any disturbance to the mechanism of the device. This is important. Because 
the load of extraneous material has produced the same reaction on the scale that took place with the known test weights, as indicated by the balance condition, we have, in effect, duplicated the known test-weight load and the extraneous material is now a known load equal in value to the known test weights. This is true because of the principle that things equal to the same thing are equal to each other. I want to add at this point that with the extraneous material in the hopper or on the scale, extreme care must be used to check for any leaks or dribble due to the nature of the material being used.

Fifth, the test weights are again placed on the scale using the aforementioned caution, and the balance very carefully reproduced and the results noticed. The known load now on the scale is twice that which was originally used. Sixth, the above steps are repeated the required number of times always exactly duplicating the balance and giving due consideration to the precautions required. Seventh, the load SR is carefully obtained. Eighth, upon the careful removal of all of the test weights and foreign material, a zero balance check is carefully made and any balance change noted.

The question of how to apply tolerance is of major importance and may be answered quite readily and simply in this manner: Since proper precautionary measures have been constantly followed throughout the testing procedure and the exact duplication of the effect of known weight by unknown weight made, plus the principle that things that are equal to the same thing are equal to each other, the total combined load of known test weights and foreign material can be properly considered as known weight, and the tolerance commensurate with that figure is applied to the device under test.

The strain-load proposition is somerhat different in nature. The principle in use is that of subjecting the working parts of the scale to sufficient stress to duplicate the effect induced in the scale and its working parts under that load, and then applying known weight to the device in an effort to determine the error produced by the known weight only at that point of strain. What we actually do in the strainload test is to stress the mechanical parts of the device at a certain point, disregarding the numerical value of the load, just considering it as a superimposed scale deck, platform, or whatever the case may be by balancing it out and temporarily reducing the available usable capacity of the scale that exists between the total capacity and the new dead load and subjecting some point in that region to the usual test.

The procedure is as follows: First, no-load sensibility reciprocal is obtained. Second, zero balance is obtained as previously described for the substitution test. Third, the light-load test is now made in the usual manner and with a duplication of zero-load balance condition, and the results are noted. Fourth, the known test weights are removed and extraneous material is added to the scale to the point desired and again a very careful balance is obtained, and the numerical value as indicated by the weighbeam or auxiliary device noted.

Fifth, the complement of known test weight is now added to the scale, proper precautionary measures are followed to prevent any unwarranted changes in the scale mechanism, and the scale is brought to balance, reproducing that balance condition obtained with the load of 
foreign material, and the numerical value is noted. The arithmetical difference bet ween the two numerical values determined in this manner is the reaction of the scale to the complement of known test weight, while the scale is under stress, and the difference between the figure and the known weight is the error.

Sixth, this process is repeated the necessary number of times required to test the device at the desired fractions of and to the capacity, being careful not to exceed it. Special attention is given to that range of weights at which the scale is normally used or at which there may be a question of error.

Seventh, obtain the full-load sensibility reciprocal.

Eighth, remove all test weight and strain load carefully, if it is possible to do so, and obtain any zero-balance change. In the strain-load test, the tolerance is applied to the results obtained with the use of the sealed weights employed only.

The question as to which test to employ is one that confionts the field operator whenever he finds that he cannot employ the conventional test procedure, and unless he has direct orders to the contrary, may best be decided by giving due consideration to a number of factors. A general run of these factors-not listed in the order of importance, for this may vary from job to job-may be listed as follows:

The total capacity and type of the device.

The accessibility.

The complement of known test weights a vailable.

The kind and arailability of extraneous material to be used as a strain load.

The facilities for handling this foreign material.

The time factor and labor problems involved.

The prices of the commodities passing over the device.

Whether or not the scale is involved in weight discrepancies or disputes.

The general condition and maintenance of the device.

Whether or not the device has been used where a court case is involved, and the importance of the degree of aceuracy required by the operator.

Other jurisdictions may find themselves compelled by the wording of theil statutes, as we in New. Jersey do, to test scale equipment not in commercial service, and it is usually that equipment to which the last of the foregoing items has reference.

Most professions and businesses have available a number of handbooks and authorities to consult. Incidentally, I highly recommend that NBS Handbook H:T be studied in conjunction with NBS Handlook $\mathrm{H} 44$ on the topic just covered. It will be found that the subject is very ably covered by our $M[r$. Ralph smith of the Bureau.

I wish to thank all the officials in the Bureau of Weights and Measures who have offered to cooperate on this subject.

\section{VAPOR METERS-F. C. MOREY, NATIONAL BUREAU OF STANDARDS}

This will be a very brief discussion of the principal details of construction of vapor meter's and their testing and maintenance, and I will cover fundamentals only. Obriously, in the few mimutes available I can only touch on the high spots of an industry which has grown for more than 100 year's.

Meter's for IPG service are very similar in design and construction to those used in the so-called city gas systems, but they are usually smaller due to the high B'TU value of the fuel. The case varies with 
the manner of installation, whether indoors or outdoors, and may be of soldered copper construction, or brass, or die-cast aluminum, or cast iron. The mechanism is similar in each case. Here is a partly assembled meter, and you can see the various component parts. I will put this meter in the back of the room after the talk, and anyone who wants to come up and examine it closely may feel free to do so.

While this particular meter is not intended for LPG service, you can see the parts and see how it works. The gas is metered by means of diaphragm chambers. Down the center of the meter is a partition. The partition, plus the diaphragms, divides the meter into four metering compartments. The diaphragms move backward and forward as the meter operates-I will turn it by hand here, and you can see the tin diaphragm moving in and out.

The motion of those diaphragms is converted into rotary motion at the top by means of flags and flag arms which you see at this point. By means of the linkage, this oscillating motion is converted into rotary motion of the meter tangent. Perhaps some of you can see this rotating part and the linkage at the top. This rotary motion controls the valves, and the valves direct the flow of gas into the metering compartments.

The valves are arranged out of phase, so the meter can never get on direct dead center. The entire action of the meter is similar to a two-cylinder double-acting steam engine. The index of the meter is a revolution counter and is so geared as to indicate the passage of a definite volume of gas. LPG meters are equipped with a test hand on the index to indicate the passage of one or two cubic feet of gas per revolution. The adjustment of the meter is made by means of a screw device on the tangent; the radius of rotation of the tangent arm is controlled by means of those screw adjustments. That, of course, controls the length of stroke of the diaphragms, and hence the volume passed per revolution of the tangent.

The diaphragms are made of soft Australian lamb skins treated with oil. In recent years molded diaphragms of an impregnated fabric have been used. And in either case the material should be soft, impervious to gas, resistant to cracking over many thousands of cycles of operation, and retaining uniform flexibility over a wide temperature range and over a long period of time, and not subject to chemical attack by the possible components of the gas.

As to the testing of gas meters, this is best accomplished by means of a gas-meter prover. This device is a calibrated gas holder or bell carrying a scale, which is counterbalanced by means of a pulley and weights, and is sealed by means of an amnular tank filled with the sea $\mathrm{I}$ ing liquid. By connecting the prover outlet to the meter inlet, it is possible to pass a measured volume of air or gas through the meter.

Of course, we first make a shut-in test, under pressure, of the connections to determine that all connections are tight, the pressure being measured by means of a small water gauge. The connections are tested by applying a small pressure from the prover; and if the water gauge remains steady, with the meter outlet sealed, then we know the connections are tight.

The prover valve is then opened and the meter is operated to bring the index hand into its zero position. The prover is then filled so that its scale reads zero. The valve is opened and the meter operated. 
When the test hand on the meter has made one revolution, the valve is shut off, and the prover scale is read. Meter testers become adept at operating the prover, and can stop the flow of gas at just the right moment, when the meter has indicated a discharge of 1 cubic foot, or of 2 cubic feet if it has a 2 -cubic-foot register.

The prover scale is read and the volume indicated is the amount of air passed by the meter during one levolution of the index hand. 'The error is usually expressed as percent fast or slow. Tests are made at two rates of flow, full open discharge and check rate. 'The check is a cap which fits on the outlet of the meter and has a small hole drilled in its center which will cause the meter to operate at about one-fifth of its rated capacity.

The city gas systems maintain meter shops for periodic testing and repair of meters. Each meter is brought in for test within the time period prescribed by local legislation, varying from about 5 to 10 or 12 years. Those meters whose proof does not fall within the prescribed tolerance are opened and adjusted or repaired. The prover method of testing is the only completely satisfactory method of testing gas meters. We have to recognize, however, that in LPG service the financial outlay required for the establishment of a meter-testing shop nay be prohibitive for small companies. Such companies must rely on manufacturer's' testing and repair facilities.

In some instances meters are tested by means of a reference meter which is operated in series with the meter under test. 'This practice is acceptable provided the reference meter is checked periodically and is carefully handled. It is also desirable that the connections between the reference meter and the meter under test be of adequate size and short length so that the gas will not expand in passing from the reference meter to the test meter.

In either case, whether it is tested by the series method or by the prover, it is desirable to run a slow-rate test to make sure that the meter does not hang up under pilot-light loads. A test bench is usually provided with a manifold connection to accommodate a large number of meters. The meters are connected with the source of air or gas through a connection containing a very small opening. This restriction permits the meter to make one revolution of the test hand in about 30 minutes. The meter is left connected until the test hand has made at least one revolution, and if there is any binding in the meter it is detected in that manner. This test prevents the loss of gas used by stove and water-heater pilots, whose consumption is at a very low rate, but being continuous might amount to a considerable item.

In concluding, I wish to point out that vapor meters for LPG service usually operate under conditions which are very favorable to long life and high accuracy. 'The vapor meter is free from tar or gum or dust. It is not uncommon to find meters which have been in service for 10 year's or more, still in excellent condition. 'The tendency is noted to increase the length of service in city gas systems. There is even more reason for the extended selvice in LPG meters.

The meter manufacturing companies have available for distribution bulletins on the method of testing meters, the use of provers, and so on. I have two of them here, which I will put on display with the meter. I also wish to call your attention to this bibliography of gas meters and metering which contains more than 1,000 references and 
will be available soon for distribution by the American Gas Association. 'The older edition, I think, is still available at the present time, but this is a new edition.

MEASURE-CONTAINERS AND NON-MEASURE-CONTAINERS-GEORGE W. WARNER, WISCONSIN

In starting this discussion I would like to refer briefly to the definitions in Handbook H44 covering measure-containers and milk bottles. In H44, page 52, under Definitions, a milk bottle to be sucl must be used for the measurement and delivery at retail of milk. In H44, page 49, under Definitions, a measure-container is one that is intended for measurement of a commodity from bulk on the basis of liquid measure, the measurement being made at the time of retail sale.

The paper milk containers that are filled with a measuring machine are non-measure containers; most of them are labeled "single service container"s" or "one-way" containers, or some other similar name. In Wisconsin, under our present milk-bottle law, these containers are classed as milk bottles. We have had no very serious difficulty, but we are trying to get our law amended so it will harmonize 100 percent with the specifications in $\mathrm{H} 44$. In getting the law amended, we wish to have a provision in the law to prevent odd quantities of milk from being sold in the nonmeasure container's.

I believe New York State, and perhaps other States, have a reguration covering single-service containers that probably takes care of the odd quantities of milk. Mr. Baker probably can advise us on this point.

In Wisconsin we consider the buckets used by the retail dealer in selling ice cream from bulk, and also commodities like oysters, as good examples of the measure containers. It might be argued that ice cream is not liquid at time of sale, but the manufacturer packages it in terms of liquid measure, so why not the retailer?

As members of the Conference know, measure-containers are not legal in the 12-fluid-ounce size, but the manufacturer-at least in Wisconsin-packages commodities like cottage cheese in 12-fluid-ounce containers, which cartons, except for size, could be used by the retail dealer in his sales from bulk. This has not caused us very much difficulty as most retail dealers selling this commodity from bulk sell it by weight or, if not by weight, they are using cartons that contain 8 or 16 fluid ounces. Here again, we have a situation where a few commodities are sold by weight or on the basis of weight but which commodity is not actually weighed but is measured.

A commodity, for instance, like cottage cheese, that is about the same weight as water, presents no difficulty whatever, as 12 fluid ounces of most kinds of cottage cheese will weigh 12 onnces avoirdupois. TVe believe that a sale of 12 ounces aroirchupois of cottage cheese, if correct, by the retail dealer-the sale being made from bulk-takes the sale out from under the definition of measure-container because under the definition of measure-container the sale must be on the basis of liquid measme. This may sound a little complicated, but I believe that in sales of this kind, made in this way, there is no conflict with the definition for a measure-container in $\mathrm{H} 44$.

Mr. Rogws. 'There is, of course, a line of demarkation between the single-service measure-container and the container used for the pack- 
aging of foods. Sometimes that line of demarkation is very finely drawn. Tre have been asked whether we test containers that are filled at the factory level. We most certainly do; we hold those to the same approval requirements as are enforced with respect to other measurecontainers. But there is one container that we will not accept. Efforts are being made to break down the standard that has existed not only in our State but in a great many other States by introducing a single-service $1 / 3$-quart container for milk and cream. TVe are told that these are marked to show their contents, so there is no deception. IVe will not accept that container even at the factory level and we will not approve it. We are able to hold the line on this, because our milk bottle law definitely states the standards that are to be employed. Our position is being supported by our Department of Agriculture, and the dairy industry.

Then there are those people who vend milk in factories who like to use a 10-ounce container-approximately 1/3 quart. Again we are holding the line. If we break down just one law on which we have standards, there is no telling how far this will go. I should like to serve notice on anyone who may want to introduce $1 / 3$-quart bottles for milk or cream into New Jersey that we will not accept them.

\section{ADDITIONAL TOPICS BROUGHT UP BY OFFICIALS AND BY ASSOCIATE MEMBERS} OF THE CONFERENCE

Mr. Fuller. I wish to bring up a subject which I think should be worked on during the coming year. I refer to the increasing use of siack-filled containers, which create unfair competition between busiliessmen and are a form of deception with respect to the purchasers.

This matter was forcefully brought to onr attention recently because of competition between several packers of potato chips. The argument was advanced that since potato chips are fragile they must be put up in large containers to avoid breaking them up. Competition went so far in the direction of increasing the size of the containers that finally the containers were only a little over half filled. It is true that these packages were correctly labeled as to their net weight. But too many shoppers buy on the basis of eye appeal. 'The packer' who was marketing what a ppeared to be the largest package bnt which was really the worst filled, was having the biggest sales. So we took him in. As a defense he set np a whole table full of breakfast foods and other commodities, many of which are being distributed nationally, and opened them mp before the judge to show the amount of slack filling on all of them. It was represented that this practice was a recognized trade custom and that we shonld not pick on a local hometown fellow when these packages were coming in from all over the country. 'The result of the case was that the judge issued a restraining order which we have not yet been able to dissolve. TVe are working on the problem, but I think it would be well if investigations of this slack-filling problem were made in every section of the country during the coming year. By doing this perluaps we can accomplish something and make a report on it at our next Conference.

Mr. Rogrers. I an 100 percent in agreement with what Mr. Fuller has said and I know that the condition exists and that it is difficult to do much about it. But the Federal Food, Drug, and Cosmetic Act 
does have a very definite clause relative to slack filling and false and ieceptive containers. How thoroughly that provision is being enforced I do not know.

The Secretary. I have a communication from the Ladies' Committee, in which they speak for the ladies attending this Conference, which I should like to insert into the record at this point. This communication reads as follows:

To the National Conference on Weights and Measures: The ladies attending the Thirty-fifth National Conference on Weights and Measures wish to go on record as expressing their sincere thanks and appleciation for the program of entertainment provided for their pleasure while attending this Conference. They further wish to express their desire that similar programs of entertainment be arranged for in the future, as a means of encoulaging the attendance of the ladies at these meetings.

Respectively submitted.

Mrs. R. E. MEEK, Ohairman,

Mrs. W. S. Busser,

Mrs. J. M. DieTz,

Ladies' Committee.

\section{REPORT OF THE NATIONAL CONFERENCE COMMITTEE ON RESOLU- TIONS, PRESENTED BY J. J. LEVITT, CHAIRMAN}

\section{APPRECIATION TO DIRECTOR AND STAFF OF THE NATIONAL BUREAU OF STANDARDS}

Whereas, Dr. E. U. Condon, R. W. Sinith, W. S. Bussey, and their very able and efficient staff have extended valuable assistance and guidance to this Confelence, of which the Conference is very grateful : Therefore, be it

Resolved, That this, the Thirty-fifth National Conference on Weights and Measures, does hereby record its grateful appleciation to the above members of the National Bureau of Standards.

\section{APPRECIATION TO COOPERATING OFFICIALS}

Whereas, the governing officials of the various States and municipalities, through their manifest intelest in weights and measures work, have made it possible for their respective jurisdictions to be represented at this Thirty-fifth National Conference on Weights and Measures; Therefore, be it

Resolved, That this, the Thirty-fifth National Conference on Weights and Measures, does appreciate such cooperation and assistance and wishes to make this resolution a part of the records of this Conference.

\section{APPRECIATION TO THOSE PARTICIPATING IN PROGRAM}

Whereas, various committees, speakers, and individuals have given generously of their valuable time and efforts to make this, the Thirty-fifth National Conference on Weights and Measures, a success; Therefore, be it

Resolved, That the Thirty-fifth National Conference on Weights and Measures does heleby recold its grateful appreciation to all who have contributed to the success of this Confelence.

\section{APPRECIATION TO THE PRESS AND RADIO}

Wheleas, the press and radio of the City of Washington have been generous in reporting the activities of our present meeting; and

Whereas, the Scale Journal has likewise been generous in publishing news and advance notice of our present meeting; Therefore, be it

Resolved, That this, the Thirty-fifth National Conference on Weights and Measures, does hereby record its appreciation to the press and radio of the City of Washington and to the Scale Journal. 


\section{APPRECIATION TO MANAGEMENT OF HEADQUARTERS HOTEL}

Whereas, The Management of the Wardman Park Hotel has done everything within its power to make our Conference a success; Therefore, be it

Resolved, That this, the Thirty-fifth Conference on Weights and Measures, does express its warmest appreciation and thanks to the Management of the said lotel for their cordial hospitality and cooperation during our meeting; and be it further

Resolved, That the Secretary of the Conference transmit a copy of this resolution to the Management of the Wardman Park Hotel.

\section{IN MEMORY OF DECEASED MEMBERS}

Whereas, we the delegates and guests of the Thirty-fifth National Conference on Weights and Measures have learned with regret of the death of several of our esteemed associates during the past year ; and

Whereas, their passing leaves a serious gap in the ranks of weights and measures activities: Therefore be it

Resolved, That we, the delegatcs and guests of the Thirty-fifth National Conference do heleby exprcss our deep sorrow and sympathetic condolence for the bereaved families and for the communities of which our associates were an outstanding part.

Mr. Levitr. The next resolution is in memory of Harry M. Roeser. This is a special resolution, which the Committee thought it proper to introduce, and I think that we would be very remiss in our obligations if we did not take action on it. All of us know that Harry was one of the outstanding men in weights and measures work for a number of years. Probably each of us has called on him for help and assistance at some time; as far as I am concerned, I know that I never called on him without receiving his help. [Reading:]

\section{IN MEMORY OF HARRY M. ROESER}

Whereas, since our last Conference, there has passed from our presence, Harry M. Roeser, a former member of the Bureau of Standards staff who contributed ably and helpfully to the programs of past Conferences; and

Whereas, we desire to record our sorrow at the loss of this esteemed Conference participant: Therefore be it

Resolved, That this Thirty-fifth Conference on Weights and Measures does herewith officially express its sorrowful regret at the passing of Mr. Roeser; and be it further

Resolved, That this resolution be made a part of the official Conference record and that a copy of it be presented to the family of Mr. Roeser.

\section{ON THE RETIREMENT OF A. J. JENSEN}

Whereas, the Chief Inspector of Weights and Measures of the State of North Dakota, Mr. A. J. Jensen, has, this past 18 jears, faithfully attended the National Conference on Weights and Measures, serving in the bcst interests of his State and carrying out his committee assignments faultlessly ; and

Whereas, we have been advisd that his services as Chief Inspector have been terminated and that we will, in future meetings, be deprived of his bubbling enthusiasm: Therefore be it

Resolved, That we express to him our regrets that his connections with our public services have been severed, and that we extcnd our well wishes in his future undertakings-Good Luck, Al!

\section{ON BUDGETARY PROCEDURE :}

Whereas, attention has been called by Dr. E. U. Condon, President of this Conference, to the need of uniformity in the administrative work of weights and measures including budgetary procedure; and

${ }^{7}$ Following the adjournment of the Conference, the President requested the Conference Committee on Weights and Measures Education to conduct the study contemplated by this resolution. 
Whercas, the need for such uniformity is recognized by the members of this Conference: 'Therefore be it

Resolved, That we, the members of this, the Thirty-fiftli National Conference on Weights and Measures, do recommend that the President of this Conference designate one of the present standing Committees or appoint a new committee to carry out these suggestions.

\title{
ON THE TESTING OF RAILWAY TRACK SCALES ${ }^{8}$
}

Whereas, the President of this Conference has presented to this bods the question of the testing of railway track scales by the States, and has reconmended that this question be given careful consideration : Therefore be it

Resolved, That a committee of threc nrembers of this Conference be alpointed to study and report at the next Conference on the practicability of State supervision orer railway track scales and their use, this committee to consult with accredited representatives of the railway industry, to ascertain the practical requirements.

Mr. LnvitT. 'The next resolution may be somewhat controversial. The resolution is not directed to any individual, but the Committee agrees with the principle expressed in the resolution and has felt it necessary to bring the subject before this Conference. [Reading:]

\section{ON THE BASIS OF COMPUTATION FOR PRICING CHARTS}

Whereas, it has been brought to the attention of the Thirty-fifth National Conference on Weights and Measures that thele are in use certain so-called "Pricers" or "Pricing Charts" which purport to give the total-price computations for a series of commodity weights and for a series of unit pricas, which computed values are based upon the principle of showing the next higher cent whenever the mathematically correct computed value involves any fraction of a cent, however small; Therefore be it

Resolved, That this Conference, meeting in its Thirty-fiftl Annual Conference at Washington, D. C., May 23, 24, 25, and 26, 1950, does hereby record its objection to the principle of price computation described above, and does endorse the principle of price computation upon the basis of selecting the lower cent whenever the mathematically correct value involves a fraction of less than one-half cent, and of selecting the higher cent whenever a fraction of onehalf cent or more is involved.

\author{
J. J. Levitr, Chairman, \\ F. M. GREene, \\ IV. A. KERLIN, \\ WILLIAM. KiRI, Jl., \\ R. IV. SEarLes, \\ Committee on Resolutions.
}

Mr. LevitT. 'The foregoing report is signed by only a part of the membership of the Committee; that is because I was unable to reach all of the members, to have them affix their signatures. But the entire Committee is in agreement with the entire report.

A short time ago one of the members of the Conference notified me that a group of members wished $\mathrm{Mr}$. Crawford to introduce a resolution from the floor. 'This is because the resolution could not be drawn up and presented to the Committee in time for us to include it in our report. I suggest that $\mathrm{Mr}$. Crawford present his resolution at this time.

Mr. Crawrord. I wish to thank the Chairman of the Resolutions Committee for giving me this opportunity to present the following resolution:

${ }^{8}$ Following the adjournment of the Conference, the President appointed, pursuant to this resolution, the following Special Committee on the Testing of Railway Track Scales: J. P. McBride of Massachusetts, Chairman; J. E. Brenton of California ; Erling Hansen of Minnesota. 
Resolved, That the method of wholesale labeling of meat products be referred to the Committee on Methods of Sale of Commodities for their study during the coming year, and report to the next Conference.

Mr. LevitT. I now move the adoption of the report of the Resolutions Committee and the adoption of the resolution offered by Mr. Crawford.

(The motion was seconded, the question was taken, and the motion was agreed to, thus adopting all of the resolutions presented to the Conference for action.)

Mr. Howard. I wish to comment on the resolution which had to do with weight-price charts because it refers to something in which I have had a part. I agree with the principle endorsed, but I want to make an explanation relative to the origin of this book of charts.

In our work with prepackaged commodities, checking weights with prices or prices witl weights, we never used the computing charts on the scale. Instead, we used a slide rule, and I still use one if I do not have available a book of weight-price charts. We found many discrepancies. So we designed a book to use for checking, and we followed the system of the full cent because it wasn't a question of that half cent on half the items. If the weight was not as indicated or the price was not in accordance with the book on actual weighing, the man was wrong. That is where it started. Some of the market supervisor's wanted the books so they could check their items. Then some of the market operators used it. Here is an actual case of the problems they were trying to meet: When an item was priced at $\$ 1.40$ per pound the total computed price could not be read from the scale because there was no $\$ 1.40$ columu; nor was there a 70 -cent column. So the operator used the 35-cent columm and made a 2 -cent error. That was multiplied by four and became an 8-cent error. The book of charts eliminated those errors.

Let me give you an illustration: If an item sells for 96 cents per pound, the price per quarter-ounce will be $1 \frac{1}{2}$ cents. The merchant will give the fraction of the $1 / 4$ ounce in order to play safe with his marked weight. Using the book, he is compensated for that fraction of the $1 / 4$ ounce therefore. Please note that one-half of the said fraction of weight equals three-fourths cent, so really nobody is the loser. (Note: Scale tolerance is $1 / 8$ ounce, which is the equivalent of threefourths cent in this instance. In checking with the book, no tolerance is acceptable.)

I don't know what methods most inspectors use. An inspector in checking for accuracy in price against weight goes into store "A" and finds everything in order and gives a clean bill of goods on all his prepackaged commodities. He then goes into store " $\mathrm{B}$ " and finds many discrepancies. Store "A" has used the subject book in its operation. Now I know from the standpoint of "principle" that it is wrong. But I do not know that the merchant will not question the legality of being dispossessed of his method or means of operation which the inspector has already approved.

Mr. Levirre. What the Committee had in mind was that, as a matter of good business ethics, these charts should be prepared to break on the half cent, and that in preparing the book it is just as easy to do this as to break on the whole cent. We did not feel that it is good ethics to take the next higlier cent if the exact computation is, for example, one mill over the lower cent. We felt that if the value is less than $1 / 2$ cent the lower value shonld be shown, and that if it is $1 / 2$ cent or over, the next higher cent should be shown. 
REPORT OF THE NATIONAL CONFERENCE TREASURER, GEORGE F. AUSTIN, JR.

MAY 1, 1950.

Balance on hand May 1, 1950 $\$ 19.61$

Receipts:

May 26. Dues-1949 Conference

Interest accrued $\$ 1,300.00$

4. 15

Disbursements:

May 25. Social evening, Wardman Park Hotel:

Buffet lunch, 250 at $\$ 2.00$

Punch, 15 gal. at $\$ 14.00$ gal

Waitcrs' service.

Public address system

Music

Entertainment

Phone service

Transportation and

Transportation and miscellaneous

Registration services

Mimeographing services

Messenger scrvices

$\$ 500.00$

210. 00

71. 00

10. 00

120. 00

50.00

1. 50

1. 80

15. 00

30. 00

5. 00

Balance on hand May 1, 1950 $1,014.30$

309. 46

Respectfully submitted.

(Signed) Geo. F. Austin, Treasurer.

(It was moved and seconded that the report of the Treasurer be adopted, the question was taken, and the motion was agreed to.)

REPORT OF THE NATIONAL CONFERENCE COMMITTEE ON NOMINATIONS, PRESENTED BY R. E. MEEK, CHAIRMAN, AND ELECTION OF OFFICERS

Mr. R. E. Meek. Your Committee on Nominations, hoping to benefit from suggestions advanced by members of the Conference relative to nominations for ofhce, met in open session on Wednesday afternoon shortly after the tour of the laboratories of the National Bureau of Standards had been concluded. We are pleased to report that some suggestions were received and that these were given careful consideration.

The Committee respected the action taken by the Thirty-fourth National Conference with regard to the number of vice presidents and executive committeemen to be elected. Consequently, it is placing in nomination the names of six members for election as vice presidents and, in addition to the officers who will serve as executive committeemen, ex officio, the names of 15 members for election as executive committeemen.

Careful consideration was given by the Committee to several factors in its selection of nominees for office. Among these were: Fstablished custom; geographical distribution; attendance records; previous recognition; and participation in the work and affairs of the Conference.

With these factors in mind, the Committee met in closed session on Thursday afternoon and voted unanimously to submit the following nominations for office in the National Conference to serve during the ensuing year, or until such time as their successors are elected: 


\title{
OFFICERS
}

For President: E. U. Condon, Director, National Bureau of Standards.

For Viee Presidents: C. A. BAKER, of New York; J. L. Brenton, of California ; J. T. KenNedY, of the District of Columbia; V. D. Campeell, of Ohio; F. C. YarbrougH, of Charlotte, N. C. ; and H. E. Howard, of Miami, Fla.

For Secretary: RALPH W. SMITH, National Bureau of Standards.

For Treasurer: Georae F. Austin, Jr., of Detroit, Mich.

\section{EXECUTIVE COMMITTEE}

For members of the Exeentive Committee: F. M. Greene, of Connecticut; J. J. Levitr, of Illinois; James A. HilgemanN, of Fort Wayne, Ind.; J. Fred True, of Kansas; George L. Johnson, of Kentucky; O. A. KIrKLAnd, of Texas; Charles O. WILls, of Portland, Maine; J. P. McBride, of Massachusetts; Miles A. Nelson, of Michigan; Erling Hansen, of Minnesota; Joseph G. Rogers, of New Jersey; Joseph F. Blickley, of Pennsylvania; J. Roy Jones, of South Carolina; George E. Carpenter, of Vermont; and Malcolm W. JENSEN, of Madison, Wis.

Respectfully submitted.

\author{
(Signed) Roluin E. MEek, Chairman. \\ Nalls Berryman, \\ JaMes A. Bernard, \\ JAMES A. BOYLE, \\ ALFRED LIRIO, \\ WilliaM F. Masinda, \\ George W. Warner, \\ Committee on Nominations.
}

(It was moved and seconded that the Report of the Committee on Nominations be adopted, the question was taken, and the motion was agreed to.)

The Chamran: Is there any unfinished business to come before the Conference?

(There was no response.)

The Chamman. Is there any new business to come before the Conference, or is there anything anyone wishes to discuss or bring before this group before we adjourn?

(There was no response.)

The Chatrman. Gentlemen, on behalf of everyone, I thank you and members of the National Bureau of Standards for a most successful Conference.

The Thirty-fifth National Conference on Weights and Measures is officially closed.

(Thereupon, at 1:12 p. m., the Thirty-fifth National Conference on Weights and Measures adjoulned sine die.)

SECRETARY's Note.-Immediately following adjournment of the Conference, a meeting of the new Executive Committee of the Conference was held. This meetting was attended by $\mathbf{1 6}$ of the 24 members. The following decisions were made with respect to the Thirty-sixth National Conference on Weights and Measures:

The Conference will extend over four days, with two sessions on the first day, one session on the second day, two sessions on the third day, and one session on the fourth day.

The dates for the Conference will be May 22, 23, 24, and 25, 1951.

The headquarters for the Conference will be Wardman Park Hotel, Washington, D. C. 
A tour of National Bureau of Standards laboratories will not be scheduled on the program, but such a tour will be made available to those wishing to participate on the afternoon of the second day of the Conference, provided that suitable arrangements for this can be made with the National Bureau of Standards.

The morning session on the second day of the Conference will be held at the National Bureau of Standards if suitable arrangements for this can be made with the Bureau. Other sessions of the Conference will be held at the headquarters hotel.

The customary informal Conference party will be held on the evening of the second day of the Conference.

Some form of special entertainment will be provided for the ladies attending the Conference.

In lien of the customary oral presentation of State and Association reports, States and Associations will be invited to submit reports, limited to two doublespaced typewritten pages, to the Conference Secretary not later than May 1, 1951. Reports so submitted will then be mimeographed and assembled as a file of State and Association Reports, copies of which will be nade available for distribution at the Conference. "Introductions" of officials will be made as a substitute for the program items of State and Association Reports. 